Prepared in cooperation with the California State Water Resources Control Board A product of the California Groundwater Ambient Monitoring and Assessment (GAMA) Program

\title{
Status of Groundwater Quality in the California Desert Region, 2006-2008: California GAMA Priority Basin Project
}

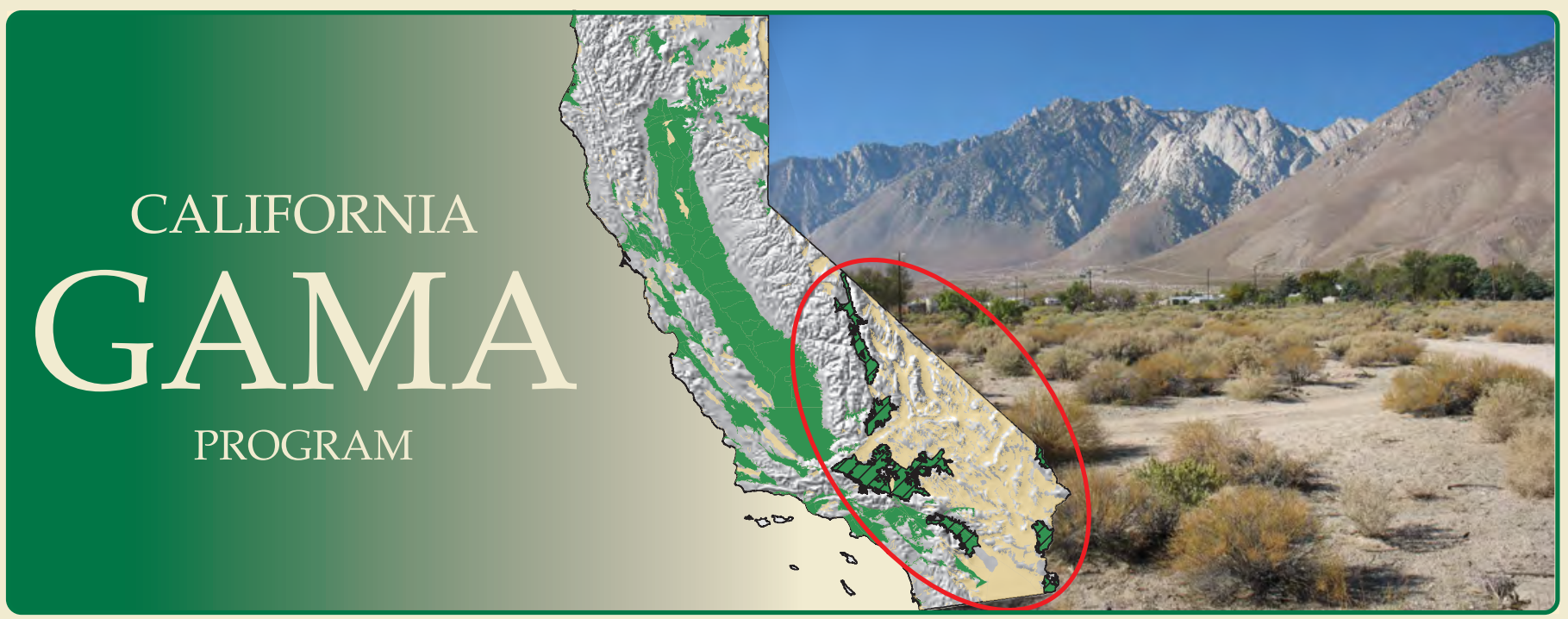

Scientific Investigations Report 2012-5040 
Front Cover Map: Groundwater basins categorized by sampling priority. Location of groundwater basin boundaries from California Department of Water Resources (CDWR, 2003).

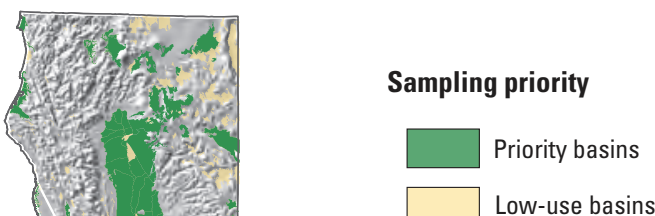

Areas that are outside CDWR-defined groundwater basins

Study area

\section{Cover photographs:}

Front cover: Looking east from Owens Valley to the Sierra Nevada Mountains, near Cartago, California. (Photograph taken by Isabel Pimentel, U.S. Geological Survey.)

Back cover: Supply well near Lancaster, California. (Photograph taken by Stephen Schmitt, U.S. Geological Survey.) 


\section{Status of Groundwater Quality in the California Desert Region, 2006-2008: California GAMA Priority Basin Project}

By Barbara J.M. Dawson and Kenneth Belitz

A product of the California Groundwater Ambient Monitoring and Assessment

(GAMA) Program

Prepared in cooperation with the California State Water Resources Control Board

Scientific Investigations Report 2012-5040 


\title{
U.S. Department of the Interior \\ KEN SALAZAR, Secretary \\ U.S. Geological Survey \\ Marcia K. McNutt, Director
}

\author{
U.S. Geological Survey, Reston, Virginia: 2012
}

For more information on the USGS - the Federal source for science about the Earth, its natural and living resources, natural hazards, and the environment, visit http://www.usgs.gov or call 1-888-ASK-USGS.

For an overview of USGS information products, including maps, imagery, and publications, visit http://www.usgs.gov/pubprod

To order this and other USGS information products, visit http://store.usgs.gov

Any use of trade, product, or firm names is for descriptive purposes only and does not imply endorsement by the U.S. Government.

Although this report is in the public domain, permission must be secured from the individual copyright owners to reproduce any copyrighted materials contained within this report.

Suggested citation:

Dawson, B.J.M., and Belitz, Kenneth, 2012, Status of groundwater quality in the California Desert Region, 2006-2008 - California GAMA Priority Basin Project: U.S. Geological Survey Scientific Investigations Report 2012-5040, $110 p$. 


\section{Contents}

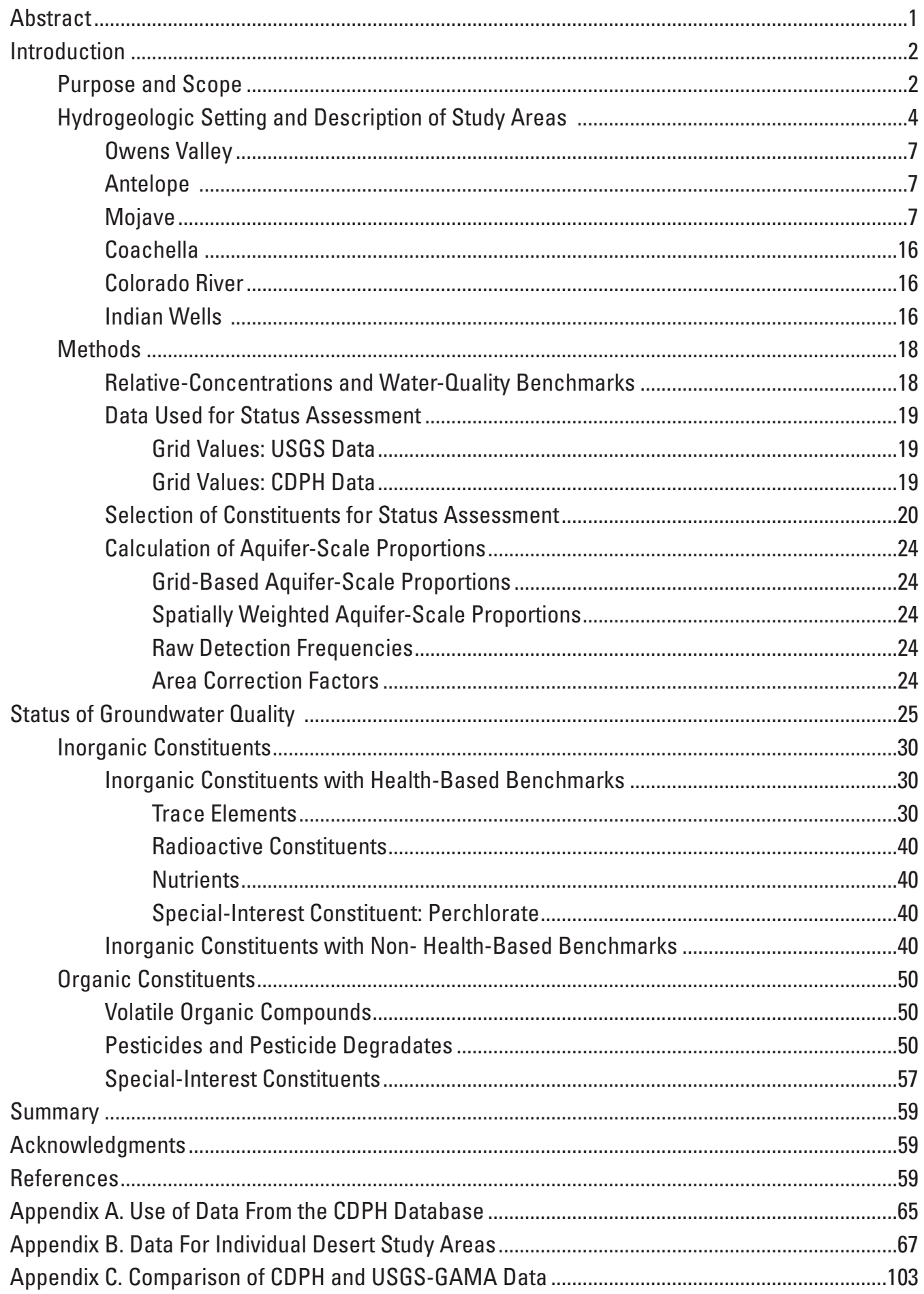




\section{Figures}

Figure 1. Map showing locations of the California Desert Region Groundwater Ambient Monitoring and Assessment (GAMA) study areas and California hydrogeologic provinces

Figure 2. Ternary diagram showing proportions of urban, agricultural, and natural land use in the California Desert Region Groundwater Ambient Monitoring and Assessment (GAMA) study areas and within a 500-meter radius of data points in those study areas

Figure 3. Maps showing general land use from the 1990s in the California Desert Region Groundwater Ambient Monitoring and Assessment (GAMA) study areas

Figure 4. Maps showing geology and locations of grid cells and grid wells used for the Groundwater Ambient Monitoring and Assessment (GAMA) Program in the California Desert Region study areas, 2006-2008: Owens Valley, Antelope Valley, Mojave, Coachella Valley, Colorado River, and Indian Wells Valley

Figure 5. Maps showing generalized directions of groundwater flow in the California Desert Region Groundwater Ambient Monitoring and Assessment (GAMA) study areas, 2006-2008

Figure 6. Graphs showing aquifer-scale proportions for inorganic and organic constituent classes in the California Desert Region as a whole and for the individual California Desert Region Groundwater Ambient Monitoring and Assessment (GAMA) study areas, 2006-2008

Figure 7. Graph showing maximum concentrations relative to health-based and non-health-based benchmarks in grid wells for classes of constituents detected in the California Desert Region Groundwater Ambient Monitoring and Assessment (GAMA) study areas, 2006-2008

Figure 8. Graph showing detected concentrations of arsenic, boron, fluoride, molybdenum, and vanadium in grid wells relative to health-based benchmarks in the California Desert Region Groundwater Ambient Monitoring and Assessment (GAMA) study areas, 2006-2008

Figure 9. Maps showing concentrations of arsenic in grid wells relative to health-based benchmarks in the California Desert Region Groundwater Ambient Monitoring and Assessment (GAMA) study areas, 2006-2008....

Figure 10. Maps showing concentrations of boron in grid wells relative to health-based benchmarks in the California Desert Region Groundwater Ambient Monitoring and Assessment (GAMA) study areas, 2006-2008.

Figure 11. Maps showing concentrations of fluoride in grid wells relative to health-based benchmarks in the California Desert Region Groundwater Ambient Monitoring and Assessment (GAMA) study areas, 2006-2008.

Figure 12. Maps showing concentrations of molybdenum in grid wells relative to health-based benchmarks in the California Desert Region Groundwater Ambient Monitoring and Assessment (GAMA) study areas, 2006-2008

Figure 13. Maps showing concentrations of vanadium in grid wells relative to health-based benchmarks in the California Desert Groundwater Ambient Monitoring and Assessment (GAMA) study areas, 2006-2008

Figure 14. Graph showing concentrations of strontium, uranium, gross-alpha radioactivity, nitrate, and perchlorate in grid wells relative to health-based benchmarks in the California Desert Groundwater Ambient Monitoring and Assessment (GAMA) study areas, 2006-2008 


\section{Figures-Continued}

Figure 15. Maps showing concentrations of strontium in grid wells relative to health-based benchmarks in the California Desert Region Groundwater Ambient Monitoring

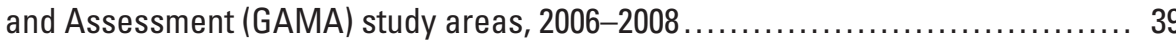

Figure 16. Maps showing concentrations of gross-alpha radioactivity in grid wells relative to health-based benchmarks in the California Desert Region Groundwater Ambient Monitoring and Assessment (GAMA) study areas, 2006-2008 _......... 41

Figure 17. Maps showing concentrations of uranium in grid wells relative to health-based benchmarks in the California Desert Region Groundwater Ambient Monitoring and Assessment (GAMA) study areas, 2006-2008

Figure 18. Maps showing concentrations of perchlorate in grid wells relative to health-based benchmarks in the California Desert Region Groundwater Ambient Monitoring and Assessment (GAMA) study areas, 2006-2008

Figure 19. Graph showing concentrations of chloride, iron, manganese, sulfate, and total dissolved solids in grid wells relative to non-health-based benchmarks in the California Desert Groundwater Ambient Monitoring and Assessment (GAMA) study areas, 2006-2008

Figure 20. Maps showing concentrations of total dissolved solids in grid wells relative to non-health-based benchmarks in the California Desert Region Groundwater Ambient Monitoring and Assessment (GAMA) study areas, 2006-2008

Figure 21. Maps showing concentrations of manganese in grid wells relative to non-health-based benchmarks in the California Desert Region Groundwater Ambient Monitoring and Assessment (GAMA) study areas, 2006-2008

Figure 22. Maps showing concentrations of sulfate in grid wells relative to non-health-based benchmarks in the California Desert Region Groundwater Ambient Monitoring and Assessment (GAMA) study areas, 2006-2008

Figure 23. Maps showing concentrations of iron in grid wells relative to non-health-based benchmarks in the California Desert Region Groundwater Ambient Monitoring and Assessment (GAMA) study areas, 2006-2008

Figure 24. Maps showing concentrations of chloride in grid wells relative to non-health-based benchmarks in the California Desert Region Groundwater Ambient Monitoring and Assessment (GAMA) study areas, 2006-2008

Figure 25. Graph showing detection frequencies and maximum relative-concentrations for organic constituents detected in grid wells in the California Desert Region Groundwater Ambient Monitoring and Assessment (GAMA) study areas, 2006-2008

Figure 26. Graphs showing concentrations relative to health-based benchmarks and detection frequencies of volatile organic compounds in grid wells in the California Desert Region Groundwater Ambient Monitoring and Assessment (GAMA) study areas, 2006-2008

Figure 27. Maps showing concentrations of chloroform relative to health-based benchmarks in the California Desert Region Groundwater Ambient Monitoring and Assessment (GAMA) study areas, 2006-2008

Figure 28. Graphs showing concentrations relative to health-based benchmarks and detection frequencies of pesticide compounds in grid wells in the California Desert Region Groundwater Ambient Monitoring and Assessment (GAMA) study areas, 2006-2008 


\section{Figures-Continued}

Figure 29. Maps showing concentrations of dieldrin and simazine relative to health-based benchmarks in the California Desert Region Groundwater Ambient Monitoring and Assessment (GAMA) study areas, 2006-2008. ...

Figure 30. Graph showing detection frequency and concentrations of $\mathrm{N}$-nitrosodimethylamine in 77 grid wells relative to health-based benchmarks in the California Desert Region Groundwater Ambient Monitoring and Assessment (GAMA) study areas, 2006-2008

Figure 31. Maps showing concentrations of $\mathrm{N}$-nitrosodimethylamine relative to health-based benchmarks in the California Desert Region Groundwater Ambient Monitoring and Assessment (GAMA) study areas, 2006-2008

\section{Tables}

Table 1. Historical and current periods of record available in the California Department of Public Health database in the California Desert Region Groundwater Ambient Monitoring and Assessment (GAMA) study areas.

Table 2. Number of grid wells used for assessment of status of inorganic constituents in the California Desert Region Groundwater Ambient Monitoring and Assessment (GAMA) study areas.

Table 3. Constituents historically reported in the California Department of Public Health database with high maximum relative-concentrations (above benchmarks) in the California Desert Region Groundwater Ambient Monitoring and Assessment (GAMA) study areas.

Table 4. Number of constituents analyzed and number detected by the U.S. Geological Survey in grid wells, with associated benchmarks for each constituent class, California Desert Region Groundwater Ambient Monitoring and Assessment (GAMA) study areas, September 2006 to April 2008

Table 5. Current aquifer proportions from grid-based and spatially weighted methods for constituents with moderate or high relative-concentrations, California Desert Region Groundwater Ambient Monitoring and Assessment (GAMA) study areas, September 2006 to April 2008.

Table 6. Summary of aquifer-scale proportions for inorganic constituent classes in the California Desert Region Groundwater Ambient Monitoring and Assessment (GAMA) study areas.

Table 7. Summary of grid-based aquifer-scale proportions for organic constituent classes in the California Desert Groundwater Ambient Monitoring and Assessment (GAMA) study areas. 


\title{
Conversion Factors, Datums, and Abbreviations and Acronyms
}

\author{
Conversion Factors \\ Inch/foot/mile to SI
}

\begin{tabular}{|c|c|c|}
\hline Multiply & By & To obtain \\
\hline \multicolumn{3}{|c|}{ Length } \\
\hline inch (in.) & 2.54 & centimeter $(\mathrm{cm})$ \\
\hline inch (in.) & 25.4 & millimeter (mm) \\
\hline foot (ft) & 0.3048 & meter (m) \\
\hline mile (mi) & 1.609 & kilometer (km) \\
\hline \multicolumn{3}{|c|}{ Area } \\
\hline square foot $\left(\mathrm{ft}^{2}\right)$ & 0.09290 & square meter $\left(\mathrm{m}^{2}\right)$ \\
\hline square mile $\left(\mathrm{mi}^{2}\right)$ & 2.590 & square kilometer $\left(\mathrm{km}^{2}\right)$ \\
\hline \multicolumn{3}{|c|}{ Flow rate } \\
\hline inch per year (in/yr) & 25.4 & millimeter per year $(\mathrm{mm} / \mathrm{yr})$ \\
\hline
\end{tabular}

Concentrations of chemical constituents in water are given either in milligrams per liter (mg/L) or micrograms per liter ( $\mu \mathrm{g} / \mathrm{L})$. One milligram per liter is equivalent to 1 part per million $(\mathrm{ppm})$; 1 microgram per liter is equivalent to 1 part per billion $(\mathrm{ppb}) ; 1$ nanogram per liter $(\mathrm{ng} / \mathrm{L})$ is equivalent to 1 part per trillion (ppt); 1 per mil is equivalent to 1 part per thousand.

\section{Datums}

Vertical coordinate information is referenced to the North American Vertical Datum of 1988 (NAVD 88).

Horizontal coordinate information is referenced to the North American Datum of 1983 (NAD 83). 


\title{
Conversion Factors, Datums, and Abbreviations and Acronyms-Continued
}

\author{
Abbreviations and Acronyms \\ AL-US U.S. Environmental Protection Agency action level \\ GAMA Groundwater Ambient Monitoring and Assessment Program \\ HAL-US U.S. Environmental Protection Agency lifetime health advisory level \\ LRL laboratory reporting level \\ MCL-CA California Department of Public Health maximum contaminant level \\ MCL-US U.S. Environmental Protection Agency maximum contaminant level \\ NL-CA California Department of Public Health notification level \\ $\mathrm{RC} \quad$ relative concentration \\ RSD5-US U.S. Environmental Protection Agency risk-specific dose at a risk factor of $10^{-5}$ \\ SMCL-CA California Department of Public Health secondary maximum contaminant level \\ SMCL-US U.S. Environmental Protection Agency secondary maximum contaminant level \\ U.S. United States \\ $>\quad$ greater than \\ $<\quad$ less than \\ $\leq \quad$ less than or equal to \\ Organizations \\ CDPH California Department of Public Health (Department of Health Services prior to July 1, 2007) \\ CDWR California Department of Water Resources \\ LLNL Lawrence Livermore National Laboratory \\ SWRCB State Water Resources Control Board (California) \\ USEPA U.S. Environmental Protection Agency \\ USGS U.S. Geological Survey \\ Selected Chemical Names \\ NDMA $\quad \mathrm{N}$-nitrosodimethylamine \\ 1,2,3-TCP 1,2,3-trichloropropane \\ TDS total dissolved solids \\ VOC volatile organic compound
}




\title{
Status of Groundwater Quality in the California Desert Region, 2006-2008: California GAMA Priority Basin Project
}

\author{
By Barbara J.M. Dawson and Kenneth Belitz
}

\section{Abstract}

Groundwater quality in six areas in the California Desert Region (Owens, Antelope, Mojave, Coachella, Colorado River, and Indian Wells) was investigated as part of the Priority Basin Project of the Groundwater Ambient Monitoring and Assessment (GAMA) Program. The GAMA Priority Basin Project is being conducted by the California State Water Resources Control Board in collaboration with the U.S. Geological Survey (USGS) and the Lawrence Livermore National Laboratory.

The six Desert studies were designed to provide a spatially unbiased assessment of the quality of untreated groundwater in parts of the Desert and the Basin and Range hydrogeologic provinces, as well as a statistically consistent basis for comparing groundwater quality to other areas in California and across the Nation. Samples were collected by the USGS from September 2006 through April 2008 from 253 wells in Imperial, Inyo, Kern, Los Angeles, Mono, Riverside, and San Bernardino Counties. Two-hundred wells were selected using a spatially distributed, randomized gridbased method to provide a spatially unbiased representation of the study areas (grid wells), and fifty-three wells were sampled to provide additional insight into groundwater conditions (additional wells).

The status of the current quality of the groundwater resource was assessed based on data from samples analyzed for volatile organic compounds (VOCs), pesticides, and inorganic constituents such as major ions and trace elements. Water-quality data from the California Department of Public Health (CDPH) database also were incorporated in the assessment. The status assessment is intended to characterize the quality of untreated groundwater resources within the primary aquifer systems of the Desert Region, not the treated drinking water delivered to consumers by water purveyors. The primary aquifer systems (hereinafter, primary aquifers) in the six Desert areas are defined as that part of the aquifer corresponding to the perforation intervals of wells listed in the CDPH database.
Relative-concentrations (sample concentration divided by the benchmark concentration) were used as the primary metric for evaluating groundwater quality for those constituents that have Federal and (or) California benchmarks. A relative-concentration (RC) greater than (>) 1.0 indicates a concentration above a benchmark, and an RC less than or equal to $(\leq) 1.0$ indicates a concentration equal to or below a benchmark. Organic and special-interest constituent RCs were classified as "low" $(\mathrm{RC} \leq 0.1)$, "moderate" $(0.1<\mathrm{RC}$ $\leq 1.0)$, or "high" ( $\mathrm{RC}>1.0)$. Inorganic constituent RCs were classified as "low" $(\mathrm{RC} \leq 0.5)$, "moderate" $(0.5<\mathrm{RC} \leq 1.0)$, or "high" $(\mathrm{RC}>1.0)$. A lower threshold value $\mathrm{RC}$ was used to distinguish between low and moderate RCs for organic constituents because these constituents are generally less prevalent and have smaller RCs than inorganic constituents.

Aquifer-scale proportion was used as the primary metric for evaluating regional-scale groundwater quality. High aquifer-scale proportion was defined as the percentage of the area of the primary aquifers with an RC greater than 1.0 for a particular constituent or class of constituents; percentage is based on an areal rather than a volumetric basis. Moderate and low aquifer-scale proportions were defined as the percentage of the primary aquifers with moderate and low RCs, respectively. Two statistical approaches_-grid-based and spatially weighted - were used to evaluate aquiferscale proportions for individual constituents and classes of constituents. Grid-based and spatially weighted estimates were comparable in the Desert Region (within 90 percent confidence intervals).

The status assessment determined that one or more inorganic constituents with health-based benchmarks had high RCs in 35.4 percent of the Desert Region's primary aquifers, moderate RCs in 27.4 percent, and low RCs in 37.2 percent. The inorganic constituents with health-based benchmarks having the largest high aquifer-scale proportions were arsenic (17.8 percent), boron (11.4 percent), fluoride (8.9 percent), gross-alpha radioactivity (6.6 percent), molybdenum (5.7 percent), strontium (3.7 percent), vanadium (3.6 percent), uranium (3.2 percent), and perchlorate ( 2.4 percent). Inorganic constituents with non-health-based benchmarks were also detected at high RCs in 18.6 percent and at moderate RCs in 16.0 percent of the Desert Region's primary aquifers. 
In contrast, organic constituents had high RCs in only 0.3 percent of the Desert Region's primary aquifers, moderate in 2.0 percent, low in 48.0 percent, and were not detected in 49.7 percent of the primary aquifers in the Desert Region. Of 149 organic constituents analyzed for all six study areas, 42 constituents were detected. Six organic constituents, carbon tetrachloride, chloroform, 1,2-dichloropropane, dieldrin, 1,2-dichloroethane, and tetrachloroethene, were found at moderate RCs in one or more of the grid wells. One constituent, $N$-nitrosodimethylamine, a special-interest VOC, was detected at a high RC in one well. Thirty-nine organic constituents were detected only at low concentrations. Three organic constituents were frequently detected (in more than 10 percent of samples from grid wells): chloroform, simazine, and deethylatrazine.

\section{Introduction}

Groundwater composes nearly half of the water used for drinking-water supply in California (Hutson and others, 2004). To assess the quality of ambient groundwater in aquifers used for drinking-water supply and to establish a baseline groundwater-quality monitoring program, the State Water Resources Control Board (SWRCB), in collaboration with the U.S. Geological Survey (USGS) and Lawrence Livermore National Laboratory (LLNL), implemented the Groundwater Ambient Monitoring and Assessment (GAMA) Program (http://www.waterboards.ca.gov/gama). The statewide GAMA Program currently consists of three projects: GAMA Priority Basin Project, conducted by the USGS (http://ca.water.usgs. gov/gama/); GAMA Domestic Well Project, conducted by the SWRCB; and GAMA Special Studies, conducted by LLNL. On a statewide basis, the Priority Basin Project focused primarily on the deeper portion of the groundwater resource, and the SWRCB Domestic Well Project generally focused on the shallower aquifer systems. The primary aquifer systems in some areas may be at less risk of contamination than shallower or deeper parts of the groundwater systems. As a result, concentrations of some contaminants in wells screened in the (deeper) primary aquifer system could be lower or higher than those in shallower (Nolan and Hitt, 2006; Zogorski and others, 2006) or deeper wells.

The SWRCB initiated the GAMA Program in 2000 in response to a legislative mandate (Supplemental Report of the 1999 Budget Act 1999-00 Fiscal Year). The GAMA Priority Basin Project was initiated in response to the Groundwater Quality Monitoring Act of 2001 \{Section 10780-10782.3 of the California Water Code, Assembly Bill 599\} to assess and monitor the quality of groundwater in California. The GAMA Priority Basin Project is a comprehensive assessment of statewide groundwater quality designed to help better understand and identify risks to groundwater resources, and to increase the availability of information about groundwater quality to the public. For the Priority Basin Project, the USGS, in collaboration with the SWRCB, developed the monitoring plan to assess groundwater basins through direct and other statistically reliable sample approaches (Belitz and others, 2003; State Water Resources Control Board, 2003). Additional partners in the GAMA Priority Basin Project include the California Department of Public Health (CDPH), California Department of Pesticide Regulation (CDPR), California Department of Water Resources (CDWR), local water agencies, and well owners (Kulongoski and Belitz, 2004).

The range of hydrologic, geologic, and climatic conditions that exist in California should be considered in an assessment of groundwater quality. Belitz and others (2003) partitioned the State into 10 hydrogeologic provinces, each with distinctive hydrologic, geologic, and climatic characteristics (fig. 1). All of these hydrogeologic provinces include groundwater basins and subbasins designated by the CDWR (California Department of Water Resources, 2003). Groundwater basins generally consist of relatively permeable, unconsolidated deposits of alluvial or volcanic origin. Eighty percent of California's approximately 16,000 public-supply wells are located in designated groundwater basins (Belitz and others, 2003). Groundwater basins and subbasins were prioritized for sampling on the basis of the number of public-supply wells, with secondary consideration given to municipal groundwater use, agricultural pumping, the number of historically leaking underground fuel tanks, and registered pesticide applications (Belitz and others, 2003). The 116 priority basins, plus additional areas outside of defined groundwater basins, were grouped into 35 study units, which include approximately 95 percent of public-supply wells in California.

\section{Purpose and Scope}

The purposes of this report are to (1) describe the hydrogeologic setting of six Desert areas (refered to in this report as the Desert Region) studied as part of the Priority Basin Project (fig. 1), and (2) provide a status assessment of the current quality of groundwater in the primary aquifers in the Desert Region.

This report is one in a series of USGS reports presenting the status of current water-quality conditions in GAMA study areas. Five USGS data-series reports (Densmore and others, 2009; Goldrath and others, 2009, 2010; Mathany and Belitz, 2009; Schmitt and others, 2009) provide tabulated results of water-quality analyses for samples collected by the Priority Basin Project in the Desert Region.

Subsequent reports will address the relation of groundwater quality to selected explanatory factors and to the change in groundwater quality over time with respect to these water-quality assessments. This report describes water-quality conditions in the Owens Valley, Antelope, Mojave, Coachella, Colorado River, and Indian Wells GAMA study areas (fig. 1). 


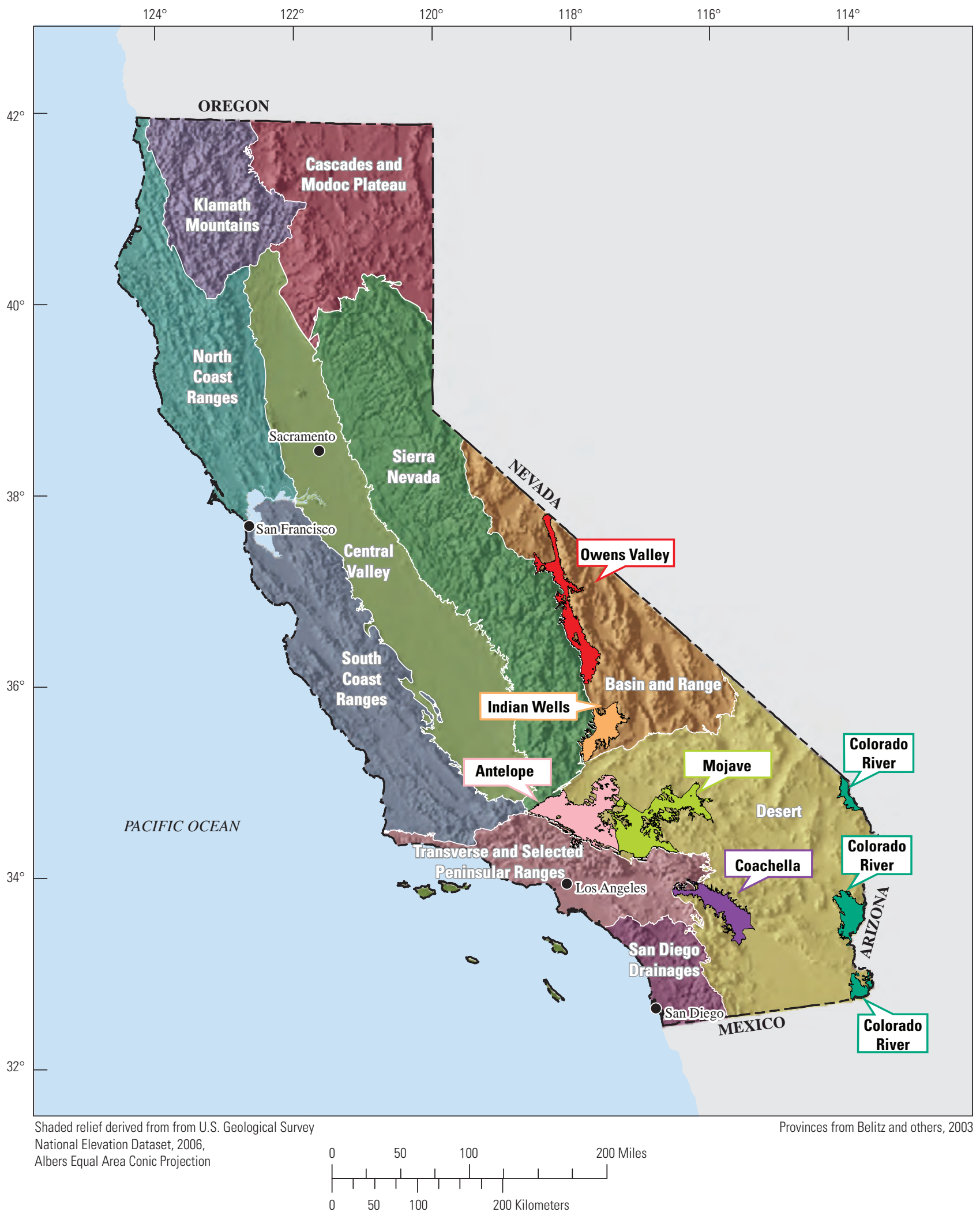

Figure 1. Locations of the California Desert Region Groundwater Ambient Monitoring and Assessment (GAMA) study areas and California hydrogeologic provinces. 
Three additional study areas in the Desert hydrogeologic province, the Central Desert, Low-Use Basins, and the

Borrego Springs areas, will be discussed in a future report.

The status assessment in this report includes analyses of water-quality data from 200 wells selected for sampling by the USGS within spatially distributed grid cells across the Desert Region, referred to as USGS-grid wells (table B1). Most of these are public water-supply wells (PSWs), but the USGS-grid wells also include other well types with similar perforation depth intervals. Samples were collected from these wells for analysis of constituents such as volatile organic compounds (VOCs) and pesticides, and inorganic constituents such as major ions and trace elements. Water-quality data from the CDPH database were also used to supplement data collected by USGS for the GAMA Program. The 200 USGSgrid-well samples were supplemented with 51 samples from the CDPH database to provide data in 251 grid cells (table B1) for the status assessment. The resulting set of USGS-grid data and selected CDPH data was considered to be representative of the primary aquifers in the Desert Region; the primary aquifers are defined as that part of the aquifer corresponding to the perforation intervals of wells listed in the CDPH database for the Desert Region. GAMA status assessments are designed to provide a statistically robust characterization of groundwater quality in the primary aquifers at the basin scale (Belitz and others, 2003). The statistically robust design also allows for comparison between basins and for synthesis of results at regional and statewide scales.

For the purposes of providing context, the water-quality data discussed in this report were compared to State and Federal health-based and non-health-based drinking-water benchmarks. The assessments in this report are intended to characterize the quality of untreated groundwater resources in the primary aquifers within the GAMA study areas, not the drinking water delivered to consumers by water purveyors. After withdrawal from the ground, water typically is treated, disinfected, and (or) blended with other waters to maintain acceptable water quality. Benchmarks apply to treated drinking water that is served to the consumer, not to untreated groundwater.

Water-quality data for samples collected by the USGS for the GAMA Program in the Desert Region and details of sample collection, analysis, and quality-assurance procedures are presented by Densmore and others (2009), Goldrath and others (2009, 2010), Mathany and Belitz (2009), and Schmitt and others (2009). Utilizing that same data, this report describes methods used in designing the sampling network, identifying CDPH data for use in the status assessment, and estimating aquifer-scale proportions (Belitz and others, 2010).

\section{Hydrogeologic Setting and Description of Study Areas}

The study areas discussed in this report cover approximately 6,050 square miles $\left(\mathrm{mi}^{2}\right)(15,670$ square kilometers, $\mathrm{km}^{2}$ ) in the Desert and the Basin and Range hydrogeologic provinces defined by Belitz and others (2003) (fig. 1). Together, these areas compose the Desert Region that is the subject of this report. The Desert hydrogeologic province occupies the southeastern corner of California and is the largest of the 10 hydrogeologic provinces in California (Belitz and others, 2003). It is bounded on the north by the Sierra Nevada and Basin and Range hydrogeologic provinces, to the east by the Colorado River, to the south by the U.S./ Mexico border, and to the west by the crystalline rocks of the San Gabriel Mountains, San Bernardino Mountains, and the Peninsular Ranges of Southern California. The Basin and Range hydrogeologic province (Belitz and others, 2003) is located in the eastern part of California (fig. 1). It is bounded to the northeast by the California-Nevada State line, to the west by the crystalline rocks of the Sierra Nevada, and to the south by the Desert hydrogeologic province.

The climate varies from semiarid to arid, with average precipitation amounts ranging from 8 inches per year in the north (Owens Valley) to less than 1 inch per year in the south (Yuma area in the Colorado River study area) (PRISM Group, Oregon State University, 2007). Northern Owens Valley is in the Great Basin Desert; southern Owens Valley and the Indian Wells, Antelope, and Mojave study areas are located in the Mojave Desert (Duell, 1987; Berenbrock and Martin, 1991; Putnam and Smith, 1995, p. 4; Izbicki and others, 2000). The Coachella and Colorado River study areas are located in the Sonoran Desert, in the part locally known as the Colorado Desert (Phillips and Comus, 2000, p. 14). Except for the Colorado River, all of the study areas have internal surface-water drainages, with streamflow originating in the surrounding mountains or along valley edges and flowing to dry lake beds. The Colorado River study area includes three separate groundwater basins along the Colorado River. The Desert study areas are dominated by natural land use, but include some urban and agricultural areas (iggs. 2 and $\underline{3}$ ). The aquifers are made up of alluvium with highly variable lithology from surrounding mountains. 


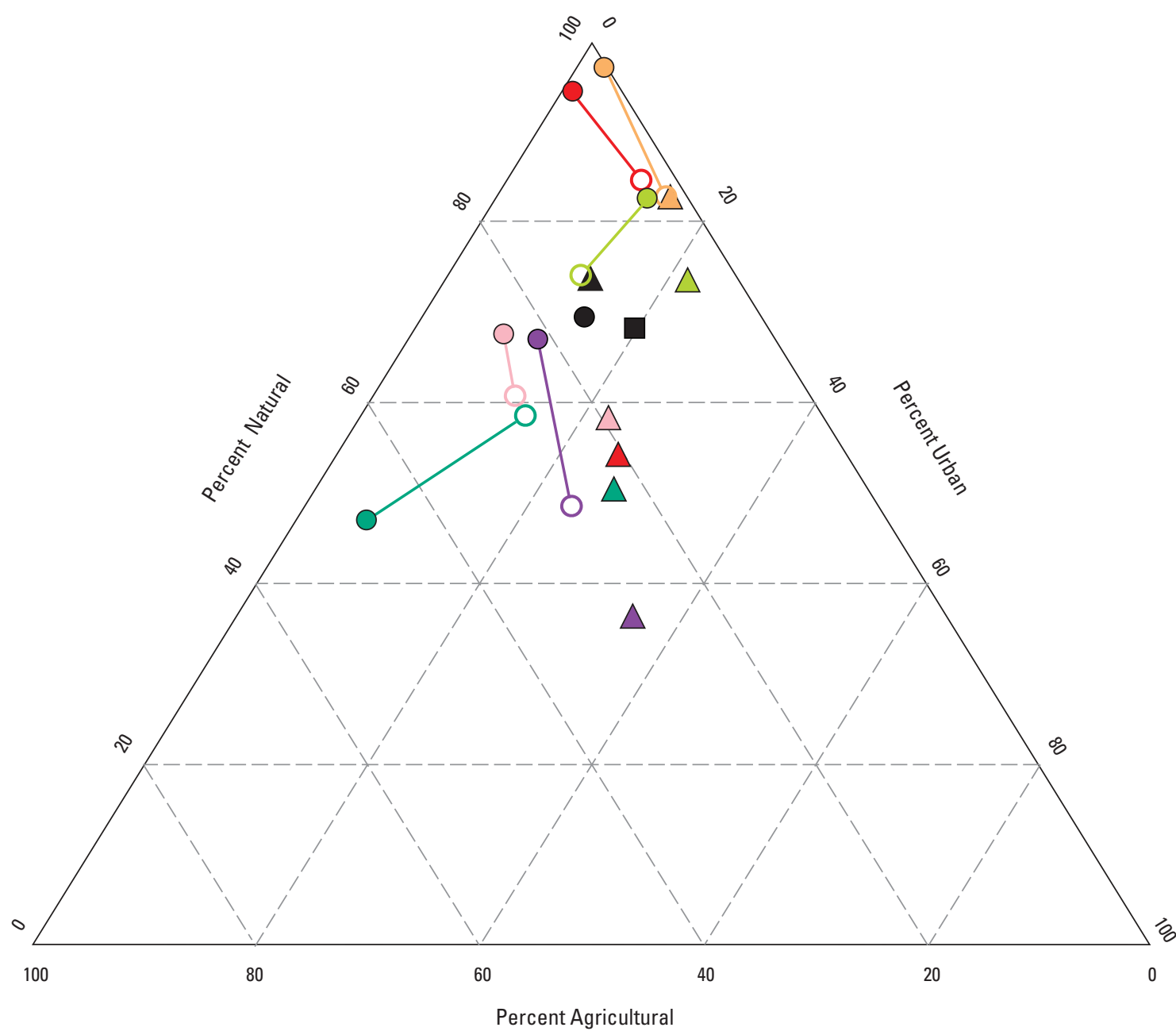

EXPLANATION

\begin{tabular}{|c|c|c|}
\hline Study Area & $\begin{array}{l}\text { Grid data points, } \\
\text { land use within a } \\
500 \text {-meter radius }\end{array}$ & $\begin{array}{l}\text { All CDPH data points, } \\
\text { land use within a } \\
500 \text {-meter radius }\end{array}$ \\
\hline Owens Valley & 0 & $\Delta$ \\
\hline Indian Wells $\bigcirc$ & 0 & $\triangle$ \\
\hline Coachella $\bigcirc$ & 0 & 1 \\
\hline Colorado River $\bigcirc$ & 0 & $\triangle$ \\
\hline Antelope $\bigcirc$ & O & $\triangle$ \\
\hline Mojave $\bigcirc$ & 0 & $\triangle$ \\
\hline
\end{tabular}

All grid points with USGS data. Land use within a 500-meter radius.

All grid points with CDPH data. Land use within a 500-meter radius.

All additional data points with USGS data. Land use within a 500-meter radius.

Figure 2. Proportions of urban, agricultural, and natural land use in the California Desert Region Groundwater Ambient Monitoring and Assessment (GAMA) study areas and within a 500-meter radius of data points in those study areas. 


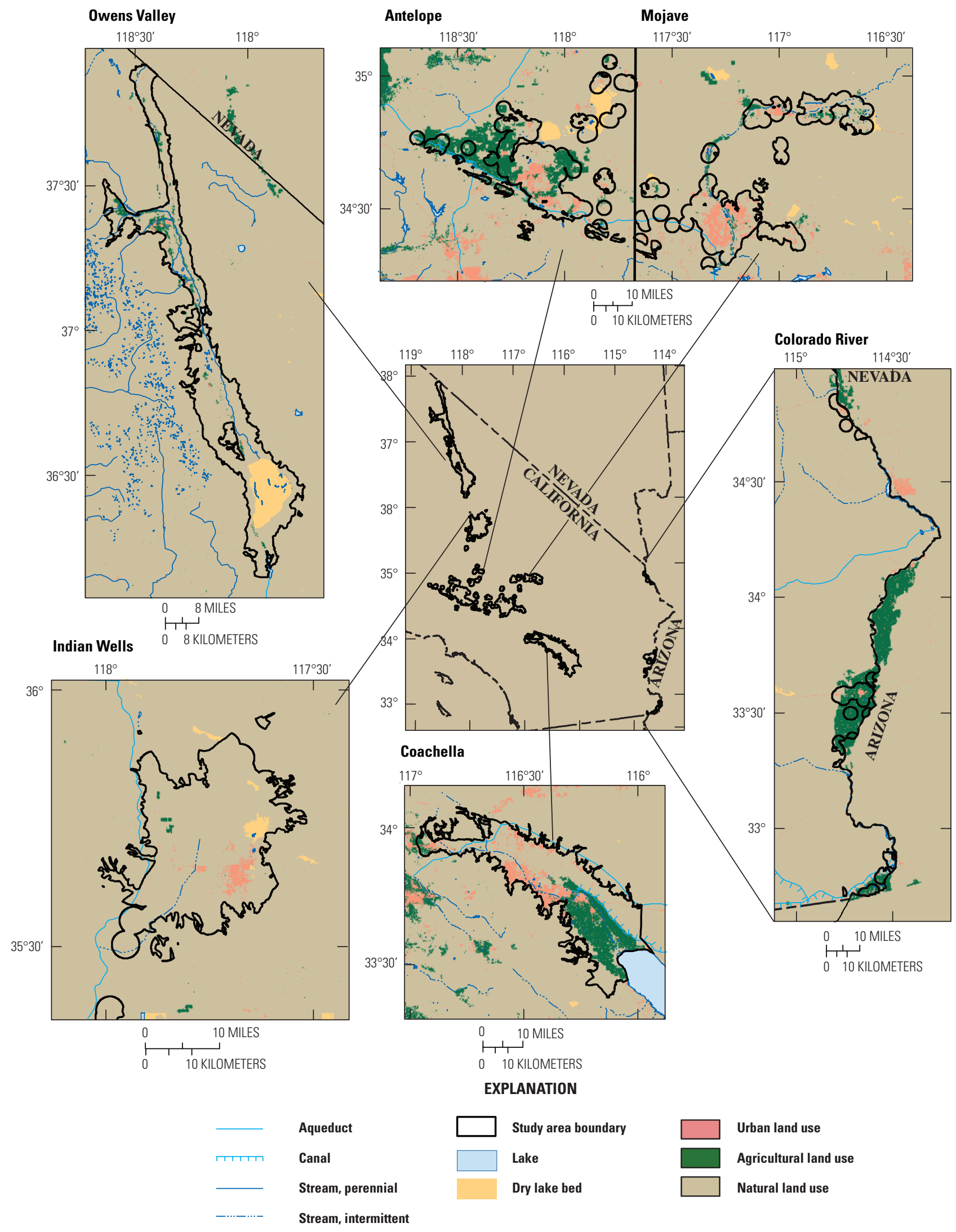

Figure 3. General land use from the 1990s in the California Desert Region Groundwater Ambient Monitoring and Assessment (GAMA) study areas. 


\section{Owens Valley}

The Owens Valley study area (OV) covers about 1,030 $\mathrm{mi}^{2}$ in Mono and Inyo Counties and includes the Owens Valley CDWR groundwater basin (California Department of Water Resources, 2003). OV is bounded on the west by the Sierra Nevada Mountains, on the east by the Inyo and White Mountains, on the south by the Coso Range, and on the north by the Volcanic Tablelands (California Department of Water Resources, 2004a) (fig. 4A).

The primary aquifer system in $\mathrm{OV}$ is contained in the alluvial valley-fill deposits (fig. 4A), and consists of an upper unconfined unit that is up to 100 feet thick and a lower confined unit that is from 10 to 500 feet (ft) thick; along the edges of the valley, there is no confining unit, and both units form one aquifer. Groundwater recharge is primarily from tributary streams, mountain-front runoff, canals, ditches, ponds, and irrigation drainage. The general direction of groundwater flow is from north to south (Danskin, 1998) (fig. 5). South of the city of Big Pine, a bedrock high separates the northern Bishop Basin from the Owens Lake Basin to the south; groundwater from the Bishop Basin discharges over the bedrock high into the Owens Lake Basin. Several faults and volcanic deposits restrict groundwater flow locally. Groundwater discharge is primarily through pumping or flowing wells, evapotranspiration, and underflow to the Owens Lake dry lakebed (Danskin, 1998).

\section{Antelope}

The Antelope study area (ANT) covers approximately 1,600 $\mathrm{mi}^{2}$ in Kern and Los Angeles Counties with small portions in San Bernardino County, at the northwestern part of the Desert hydrogeologic province (igss. 1 and $\underline{4 B}$ ). The study area includes one groundwater basin (the Antelope Valley groundwater basin), as defined by the CDWR (California Department of Water Resources, 2003). ANT is bounded to the northwest by the Tehachapi Mountains, to the south by the San Gabriel Mountains, and to the north and east by several fault systems and low-lying bedrock hills (Londquist and others, 1993; Rewis, 1995; California Department of Water Resources, 2004b) (fig. 4B).

The primary aquifers in ANT are in alluvium of Pliocene and Pleistocene age (Durbin, 1978; Duell, 1987; Sneed and Galloway, 2000; Nishikawa and others, 2001; Leighton and Phillips, 2003). In the southern part of the study area, near the mountain front, the primary aquifer is the upper aquifer described by Leighton and Phillips (2003); in previous work (such as Durbin, 1978, and Duell, 1987), this was referred to as the "principal aquifer." The upper aquifer consists of interbedded clay, silt, sand, and gravel and is unconfined. In the northern part of the study area, the primary aquifer is the confined middle aquifer, which is below the upper aquifer and a confining layer of lacustrine deposits (Sneed and
Galloway, 2000; Nishikawa and others, 2001; Leighton and Phillips, 2003). The main source of groundwater recharge is runoff from the San Gabriel and Tehachapi Mountains; additional sources are drainage from irrigation and septic systems. Imported water from the California State Water Project is used for irrigation (Duell, 1987). The general direction of groundwater flow is north and east, away from the mountains, toward the dry lakebeds and pumping (fig. 5) (Leighton and Phillips, 2003). Several faults in the study area act as partial barriers to groundwater flow (Leighton and Phillips, 2003). Groundwater discharge currently is mainly to pumping wells; prior to the start of groundwater pumping in the late 1800s, groundwater discharge was predominantly by evapotranspiration and as subsurface flow into Fremont Valley to the north (Nishikawa and others, 2001).

\section{Mojave}

The Mojave study area (MOJ) includes four contiguous CDWR-defined groundwater basins: the Upper, Middle, and Lower Mojave River Basins, and the El Mirage Valley Basin (California Department of Water Resources, 2004c-f). These basins define the extent of MOJ and cover an area of approximately 1,500 $\mathrm{mi}^{2}$ in San Bernardino County, with small portions in Kern and Los Angeles Counties (figs. 1 and $\underline{4 C}$ ). The MOJ study area is bounded on the west by the Antelope groundwater basin, the Shadow Mountains, and the Kramer Hills. It is bordered to the north by the Harper Valley groundwater basin, Iron Mountain, the Coyote Lake Valley groundwater basin, and the Calico Mountains. The eastern boundaries of the study area include the Coyote Lake groundwater basin and the Cady, Newberry, Ord, and Granite Mountains. The southernmost border of MOJ is formed by the San Gabriel and San Bernardino Mountains.

The primary aquifers in MOJ are the flood-plain aquifer and the regional aquifer. The flood-plain aquifer consists of Holocene-age deposits located in and adjacent to the current flood plain of the Mojave River. The regional aquifer consists of older Pleistocene-Pliocene-age deposits of the Mojave River that extend throughout the study area and are beneath the flood-plain aquifer. The main source of recharge to both aquifers is runoff from the San Bernardino and San Gabriel Mountains, mostly through the Mojave River channel; additional sources are irrigation, treated sewage effluent, septic systems, and imported water from Northern California delivered by the California aqueduct. Groundwater flow is generally north and then east, away from the mountain front and following the Mojave River (ig. 5). Groundwater discharge is mainly through pumping and evapotranspiration, and possibly as underflow through Afton Canyon. Historically, groundwater discharged to the dry lakebeds, but pumping beginning in the late 1800s has changed flow directions away from the dry lakes and decreased the amount of groundwater discharging to the dry lakebeds (Stamos and others, 2001). 


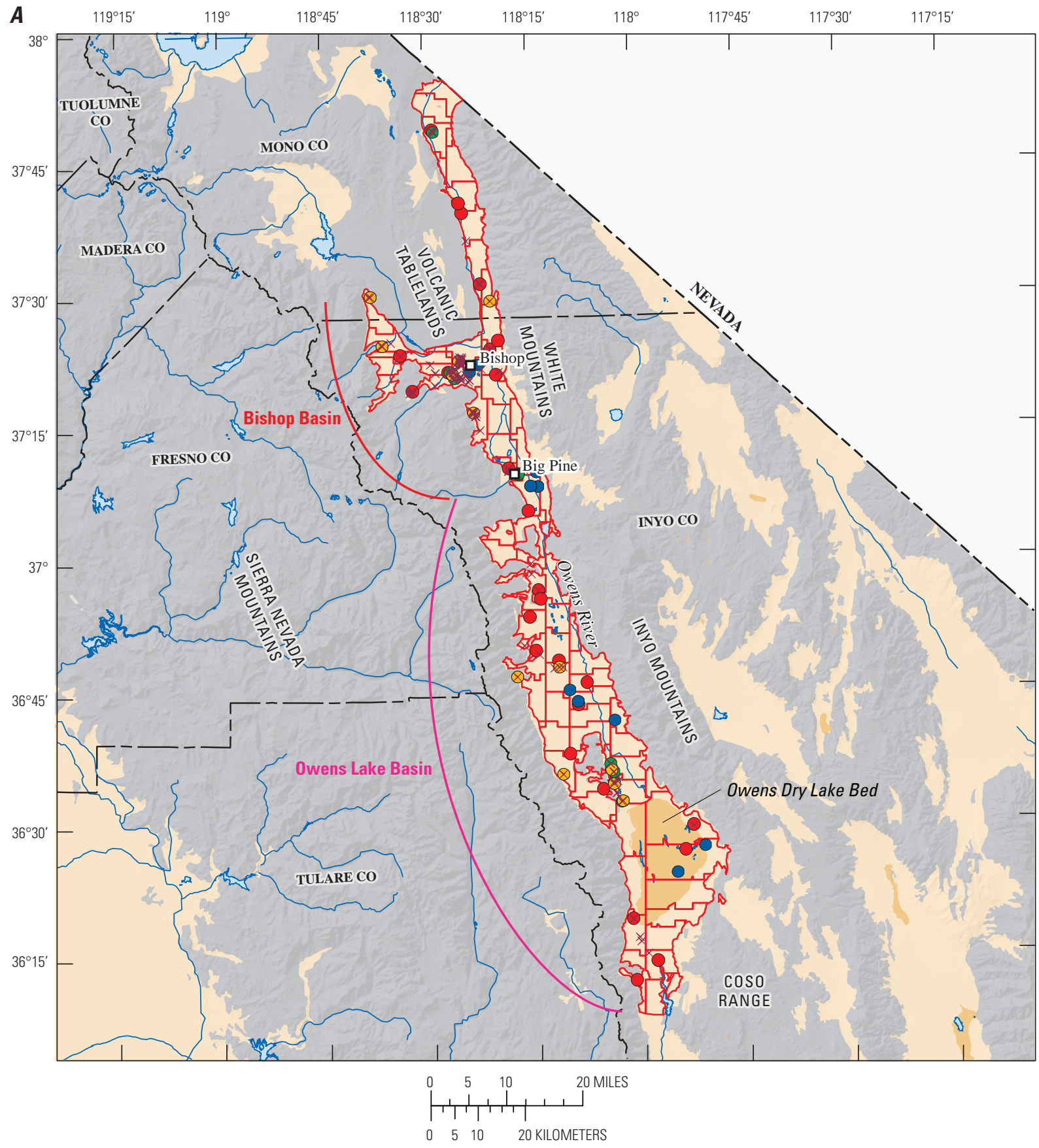

EXPLANATION

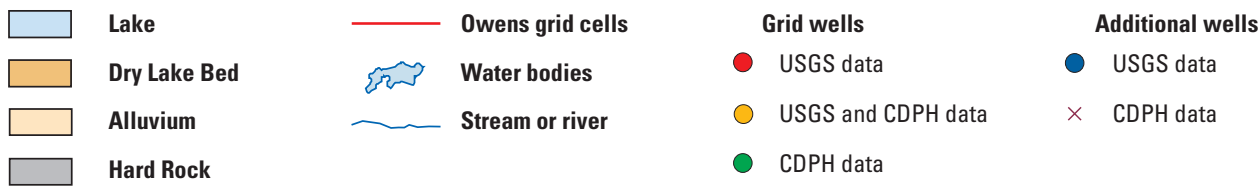

Figure 4. Geology and locations of grid cells and grid wells used for the Groundwater Ambient Monitoring and Assessment (GAMA) Program in the California Desert Region study areas, 2006-2008: (A) Owens Valley, $(B)$ Antelope Valley, $(C)$ Mojave, $(D)$ Coachella Valley, $(E-G)$ Colorado River, and $(H)$ Indian Wells Valley. 


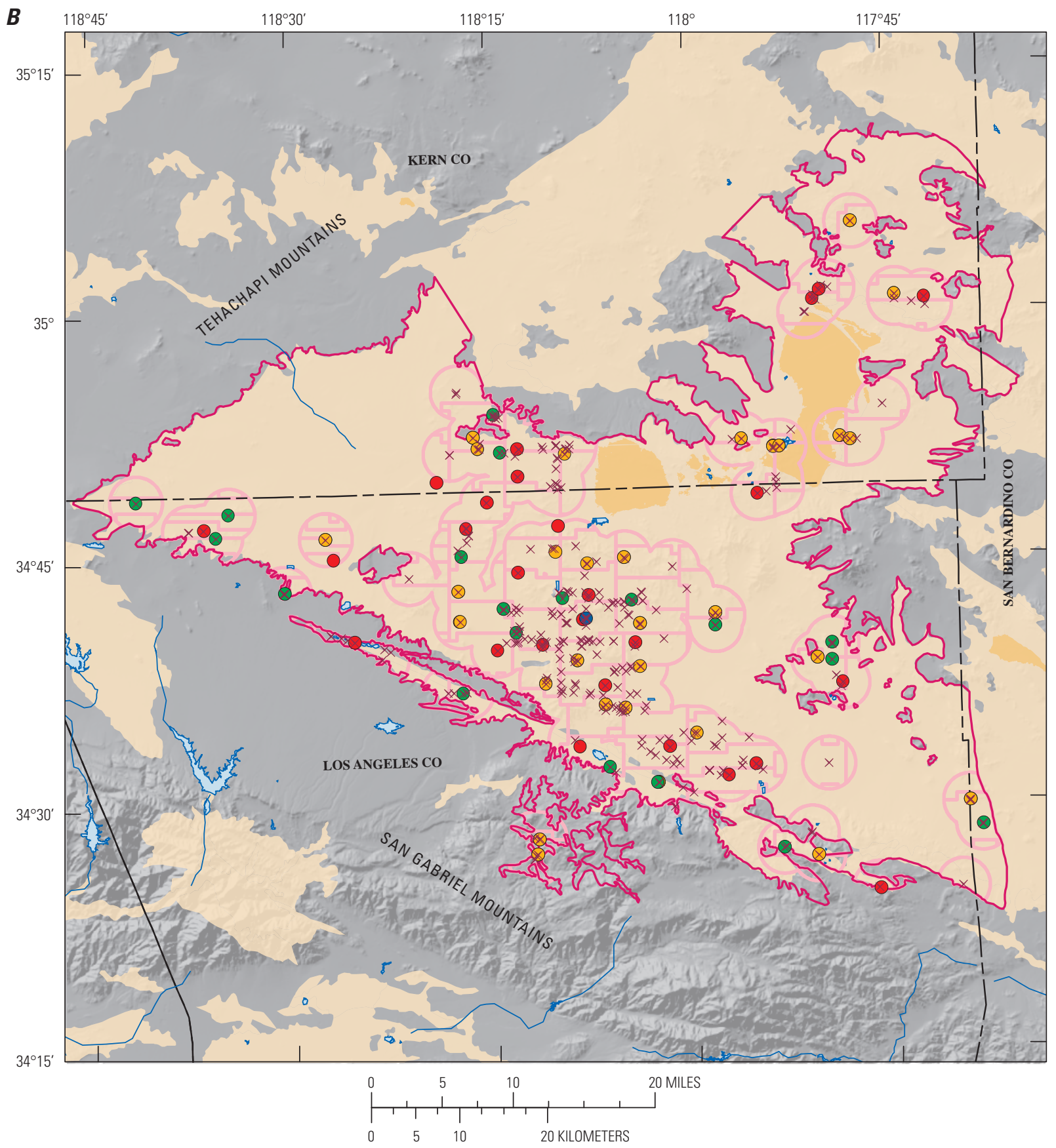

\section{EXPLANATION}
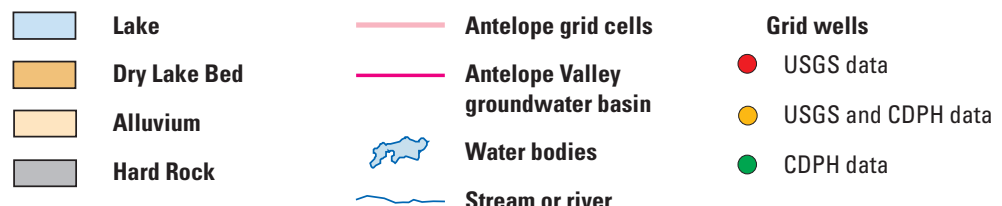

Additional wells

USGS data

$\times \quad \mathrm{CDPH}$ data

Figure 4.-Continued 


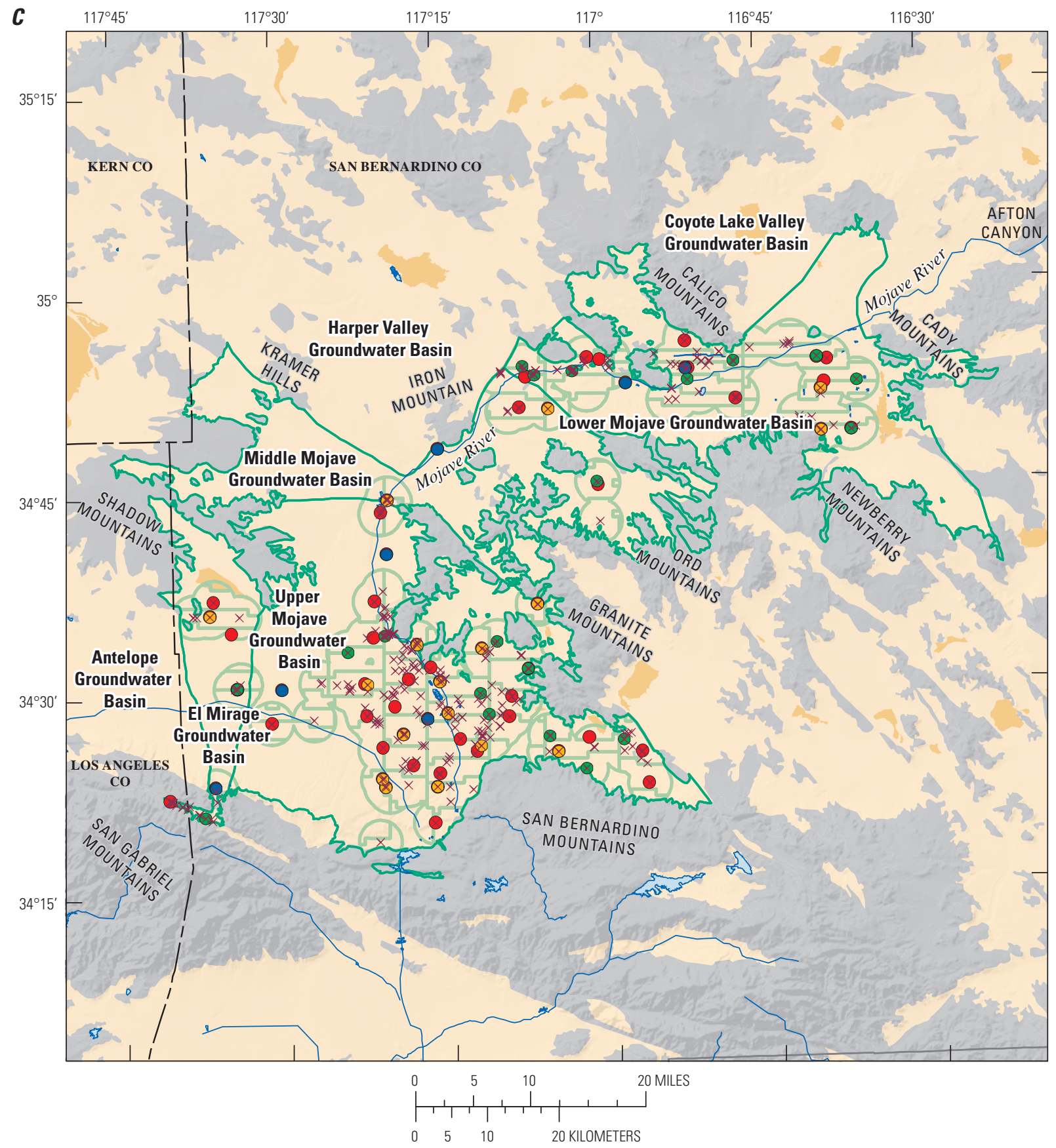

EXPLANATION

\begin{tabular}{|c|c|c|c|c|c|}
\hline Lake & & Mojave grid cells & Grid wells & & Additional wells \\
\hline Dry Lake Bed & 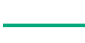 & Mojave groundwater & - USGS data & ○ & USGS data \\
\hline Alluvium & & basın & USGS and CDPH data & $x$ & $\mathrm{CDPH}$ data \\
\hline Hard Rock & End & $\begin{array}{l}\text { Water bodies } \\
\text { Stream or river }\end{array}$ & - $\mathrm{CDPH}$ data & & \\
\hline
\end{tabular}

Figure 4.-Continued 
D

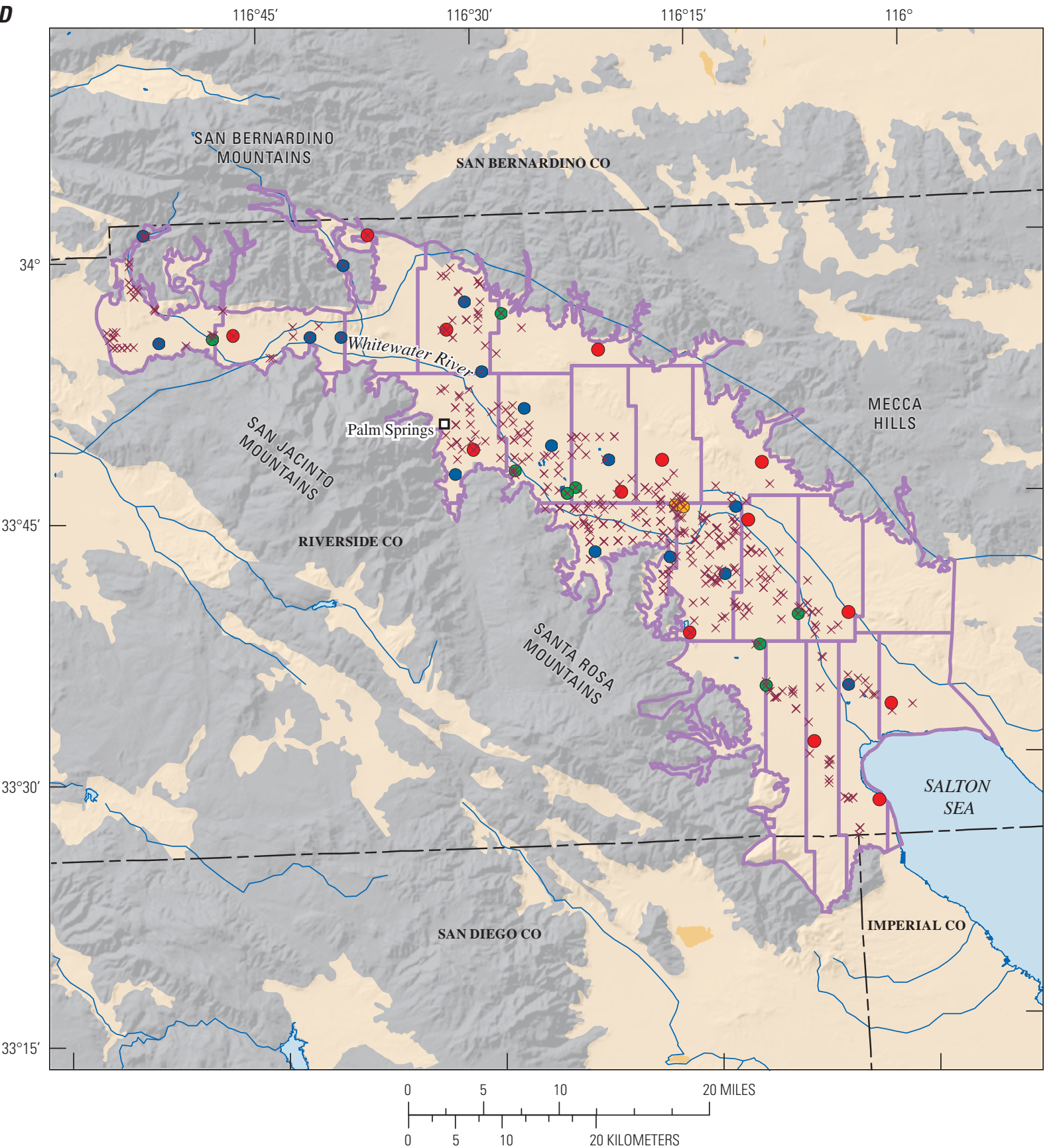

EXPLANATION

\begin{tabular}{|c|c|c|c|c|c|}
\hline Lake & 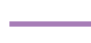 & Coachella grid cells & Grid wells & & Additional wells \\
\hline Dry Lake Bed & हnत्र & Water bodies & - USGS data & 0 & USGS data \\
\hline Alluvium & $\sim$ & Stream or river & USGS and CDPH data & $x$ & $\mathrm{CDPH}$ data \\
\hline Hard Rock & & & CDPH data & & \\
\hline
\end{tabular}

Figure 4.-Continued 


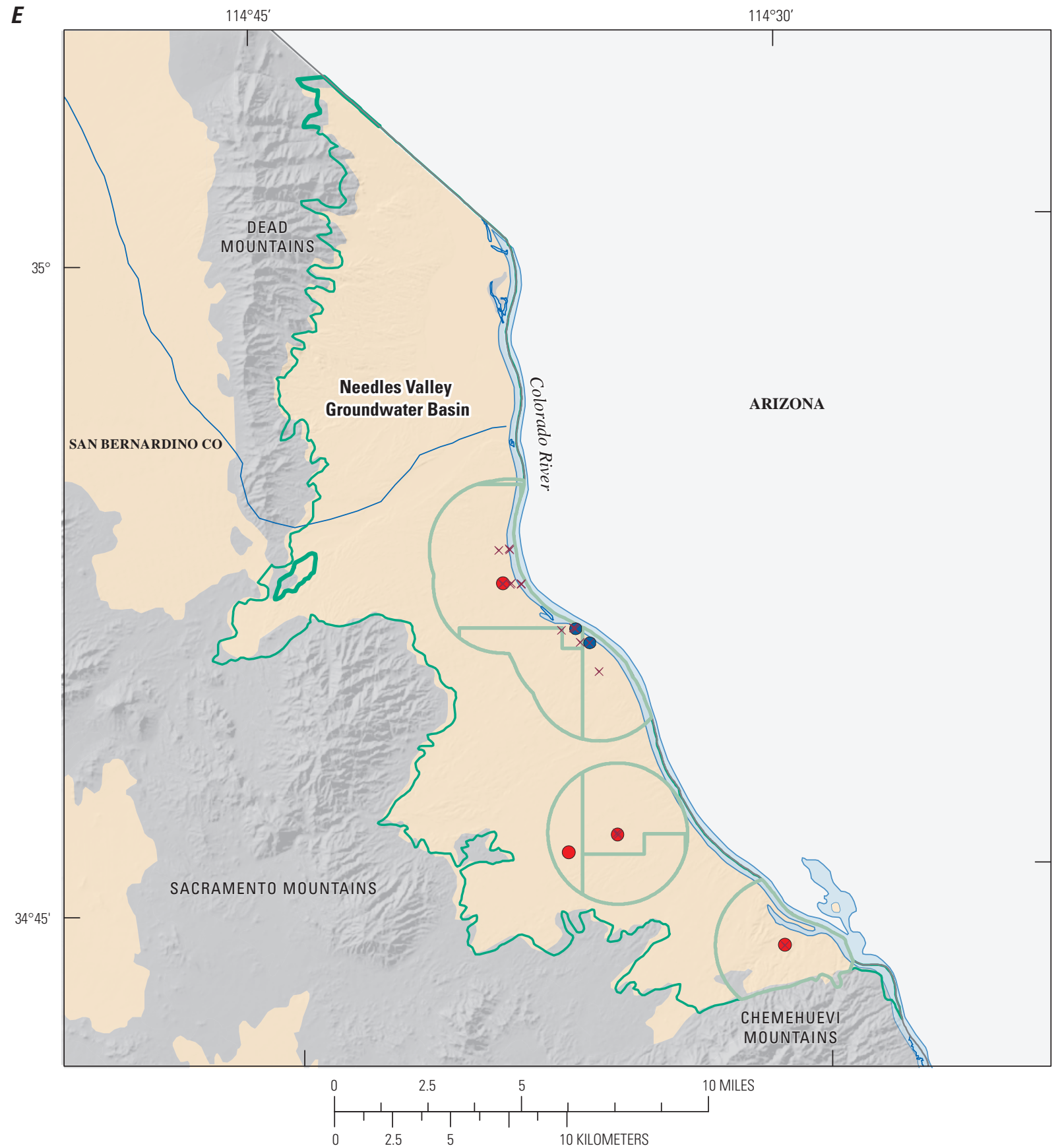

EXPLANATION

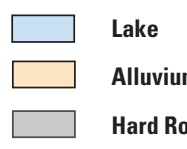

Hard Rock
Colorado River grid cells

Colorado River Groundwater basin

Water bodies
Additional wells

Grid wells
USGS data

USGS data

$\times \quad \mathrm{CDPH}$ data

Figure 4.-Continued 


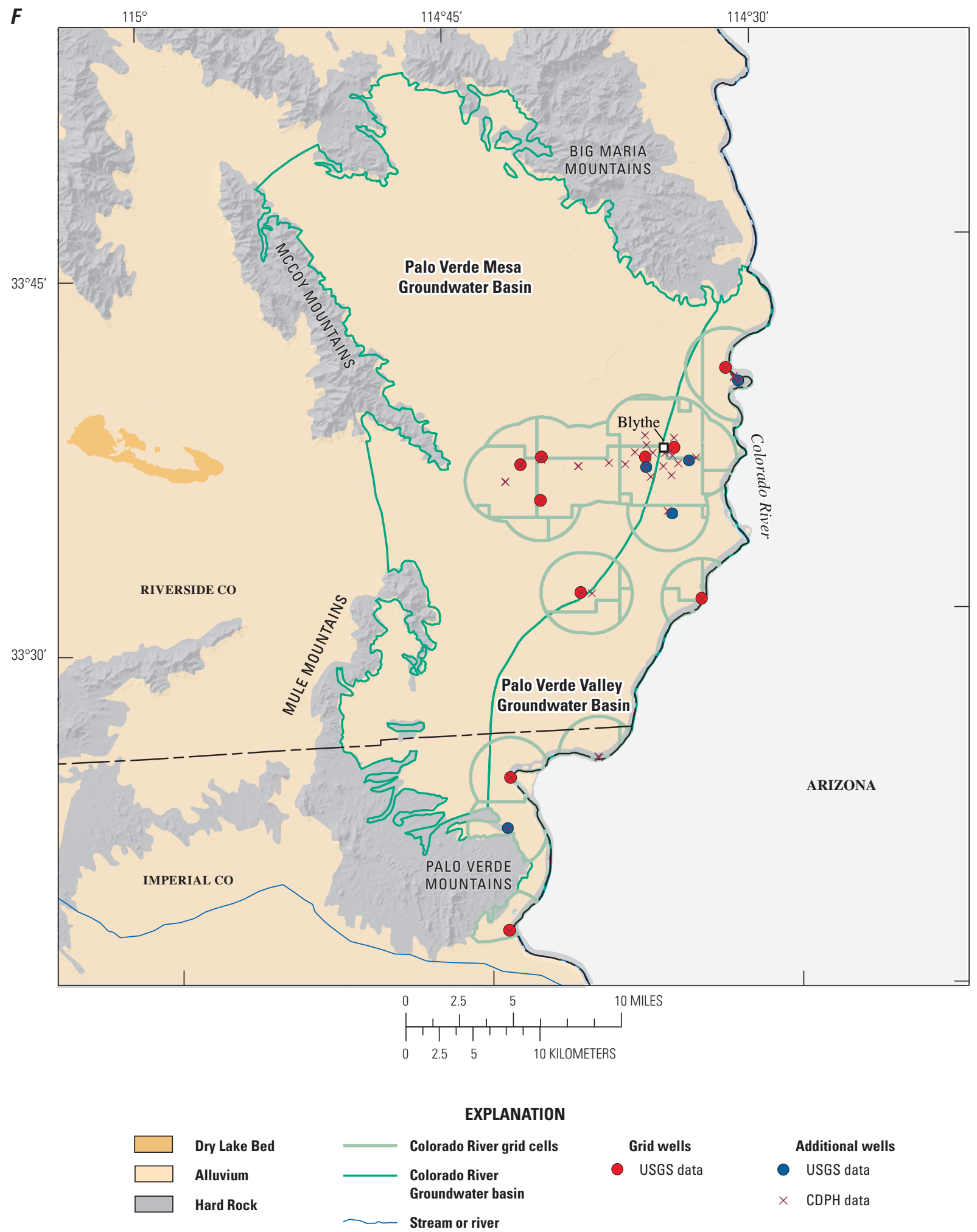

Figure 4.-Continued 


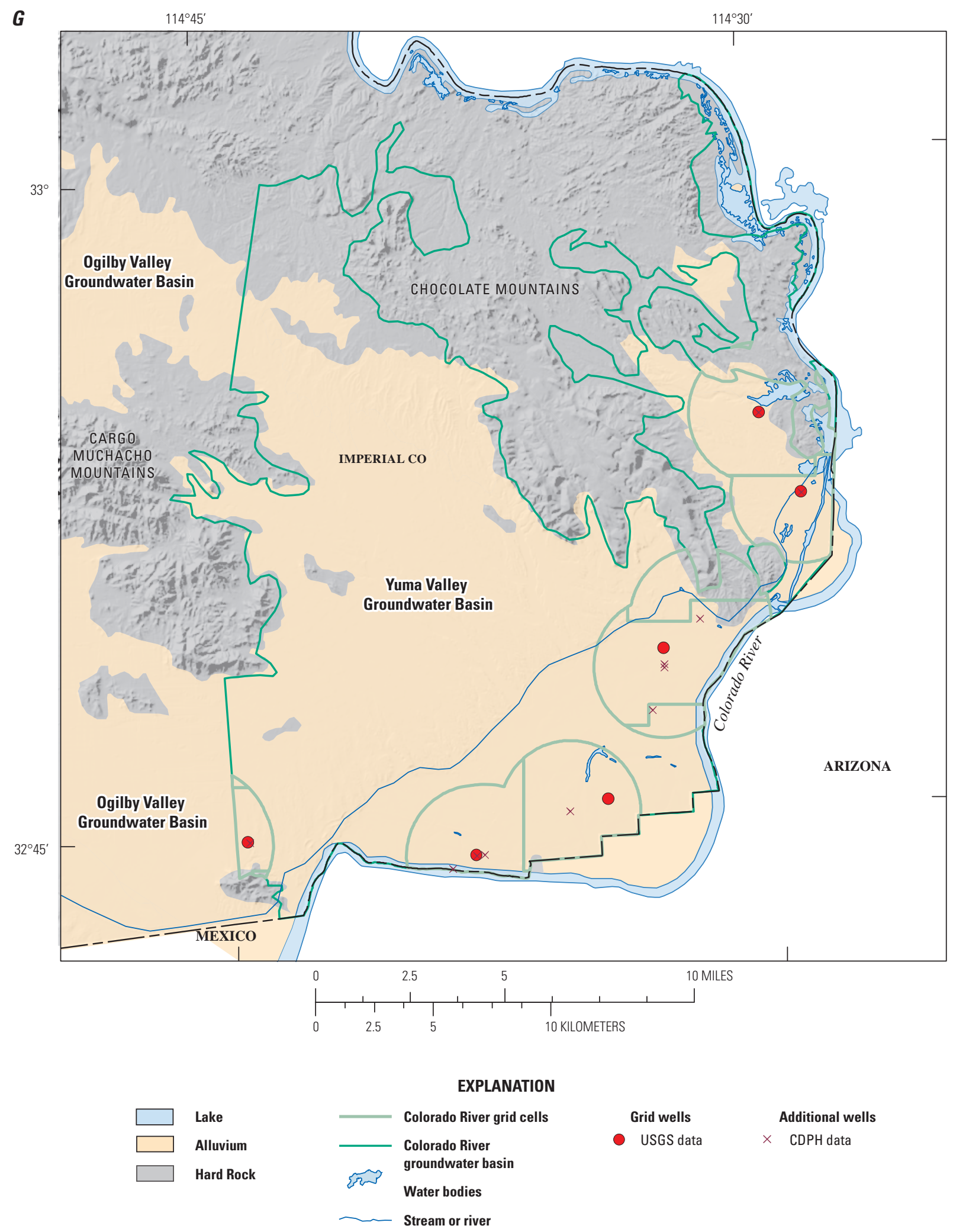

Figure 4.-Continued 


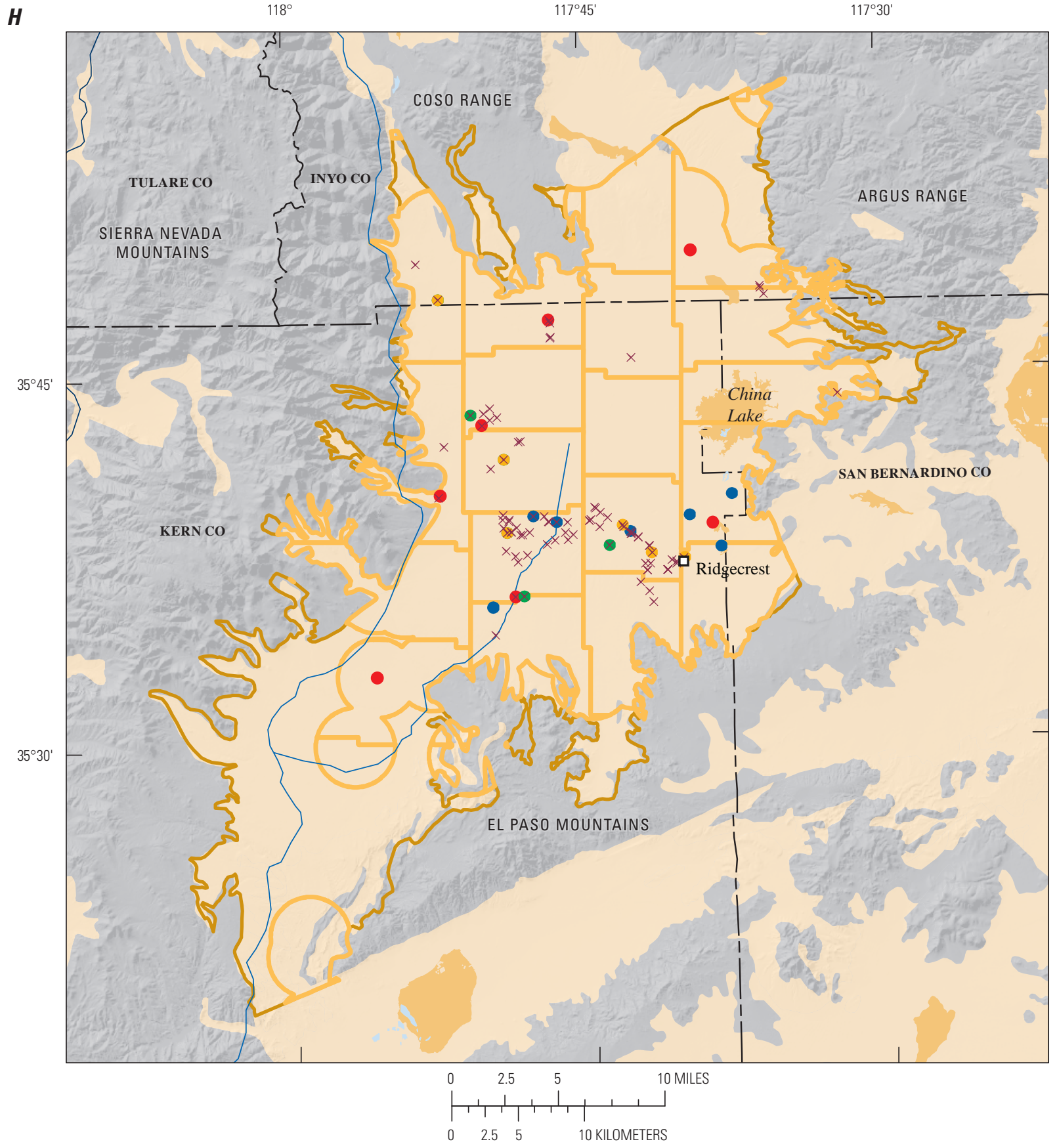

EXPLANATION

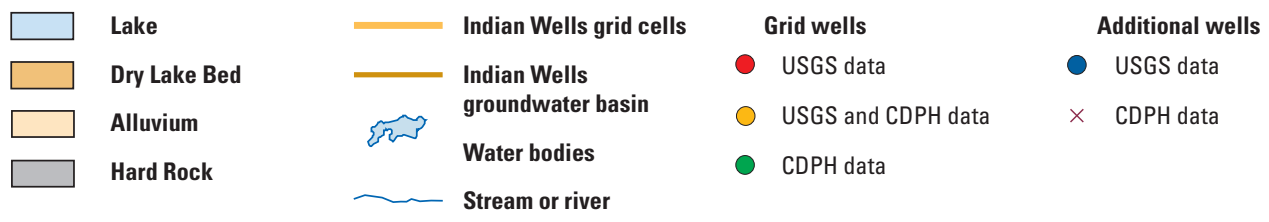

Figure 4.-Continued 


\section{Coachella}

The Coachella study area (COA), approximately $820 \mathrm{mi}^{2}$, is located almost entirely in Riverside County, but sections extend into San Bernardino, San Diego, and Imperial Counties (fig. 4D). COA includes the Coachella Valley CDWR-defined groundwater basin, which is made up of the Desert Hot Springs, Indio, Mission Creek, and San Gorgornio Pass subbasins (California Department of Water Resources, 2004g-j). The Coachella Valley is the northern expression of the Salton Trough, a landward extension of the Gulf of California (Goldrath and others, 2009). The San Bernardino Mountains and the Mecca Hills form the northern and the eastern boundaries of the valley; the San Jacinto and Santa Rosa Mountains bound the valley to the south and west; the southeastern boundary for the COA is the Salton Sea.

The primary aquifer system in the COA is in the unconsolidated, Pleistocene-Holocene valley fill. Throughout the valley, many faults in the San Andreas Fault system act as barriers to groundwater flow (Tyley, 1974). Groundwater flow is generally from the northwest to the southeast (fig. 5). Groundwater recharge is primarily runoff from the surrounding mountains, local precipitation, irrigation return, streamflow from the Whitewater River and other rivers and creeks (Tyley, 1974), and from imported Colorado River water supplied to the Whitewater River spreading grounds near Palm Springs (California Department of Water Resources, 2004h). Groundwater discharge is to evapotranspiration, to underflow to the Salton Sea and Imperial Valley areas, and to pumping wells (Tyley, 1974).

\section{Colorado River}

The Colorado River study area (COL) includes three separate subareas: Needles, Palo Verde, and Yuma (figs. $4 E-G$ ). The exterior boundaries of the study area correspond to four CDWR-delineated groundwater basins: Needles Valley, Palo Verde Mesa, Palo Verde Valley, and Yuma Valley (California Department of Water Resources, $2004 \mathrm{k}-\mathrm{n})$. The Needles Valley groundwater basin is $138 \mathrm{mi}^{2}$ and underlies the Mohave Valley in the eastern portion of San Bernardino County (fig. 4E). The basin is bounded by the Colorado River on the east, the non-water-bearing rocks of the Dead Mountains to the northwest, the Sacramento Mountains to the southwest, and the Chemehuevi Mountains to the south (Bishop, 1963). The Palo Verde groundwater basins, which include the CDWR Palo Verde Mesa and Palo Verde Valley groundwater basins, occupy $553 \mathrm{mi}^{2}$ and underlie Parker Valley in the eastern portion of Riverside County (fig. 4F). The basin is bounded by the Colorado River to the east, the non-water-bearing rocks of the Big Maria Mountains to the north, the McCoy and Mule Mountains to the west, and the Palo Verde Mountains to the South (Jennings, 1967; California Department of Water Resources, 1979). The Yuma Valley groundwater basin is approximately $193 \mathrm{mi}^{2}$ and underlies a southeast-trending valley in Imperial County (California
Department of Water Resources, 2004n) (fig. 4G). The basin is bounded by the Colorado River to the east and south, the nonwater-bearing rocks of the Cargo Muchacho Mountains on the west, and the Chocolate Mountains to the north and northeast.

The primary aquifers in each of the COL subareas are contained in alluvial deposits of the Colorado River (figs. 4E-G). These deposits consist of sand, gravel, silt, and clay laid down by the Colorado River, ranging from 100 to $600 \mathrm{ft}$ thick. In the Palo Verde basins, near Blythe, CA, some deep wells tap the Bouse Formation beneath the alluvium, which is made up of interbedded clay, silt, and sand from the Colorado River. In the Needles and Palo Verde basins, the main source of groundwater recharge is the Colorado River (fig. 5). Minor recharge is from irrigation return flows, local precipitation/runoff, and underflow from basins to the west (Metzger and Loeltz, 1973; California Department of Water Resources, 2004k-m). Groundwater discharge is to pumping wells, evapotranspiration, and occasionally to the Colorado River. In the Yuma basin, groundwater recharge is from subsurface inflow from the Ogilby Valley groundwater basin to the west and from mountain runoff; groundwater generally flows southeast and discharges to the Colorado River (California Department of Water Resources, 2004n) (fig. 5).

\section{Indian Wells}

The Indian Wells study area (IW) covers about $597 \mathrm{mi}^{2}$ in Inyo, Kern, and San Bernardino Counties and includes the Indian Wells Valley CDWR groundwater basin (California Department of Water Resources, 2004o). Indian Wells Valley is bounded on the west by the southern terminus of the Sierra Nevada, on the north by a low ridge of volcanic rocks and the Coso Range, on the east by the Argus Range, and on the south by the El Paso Mountains (fig. $4 H$ ).

The primary aquifer in IW is the "deep aquifer" described in Berenbrock and Schroeder (1994), which consists of alluvial deposits that occupy most of the valley (fig. $4 \mathrm{H}$ ) and are up to $1,000 \mathrm{ft}$ thick. In the center of the valley, beneath China Lake and other dry lakebeds, the deep aquifer is overlain by a shallow aquifer that consists of lacustrine, alluvial, playa, and sand-dune deposits. Groundwater flow is generally from the sides of the valley toward the dry lake beds (Berenbrock and Schroeder, 1994) (fig. 5). Groundwater recharge is primarily from infiltration of surface runoff from the Sierra Nevada to the west, with minor contribution by runoff from the mountains to the north, east, and south, and locally from irrigation. Prior to groundwater pumping in the 1920s, groundwater discharge from the deep aquifer was to the shallow aquifer. Starting in the late 1900s and continuing to the present, discharge was also to pumping wells in the southern parts of the Valley, and cones of depression have formed in the deep aquifer near Ridgecrest. Because of this increase in pumping, the shallow aquifer is now a source of recharge to the deep aquifer (Berenbrock and Schroeder, 1994). 


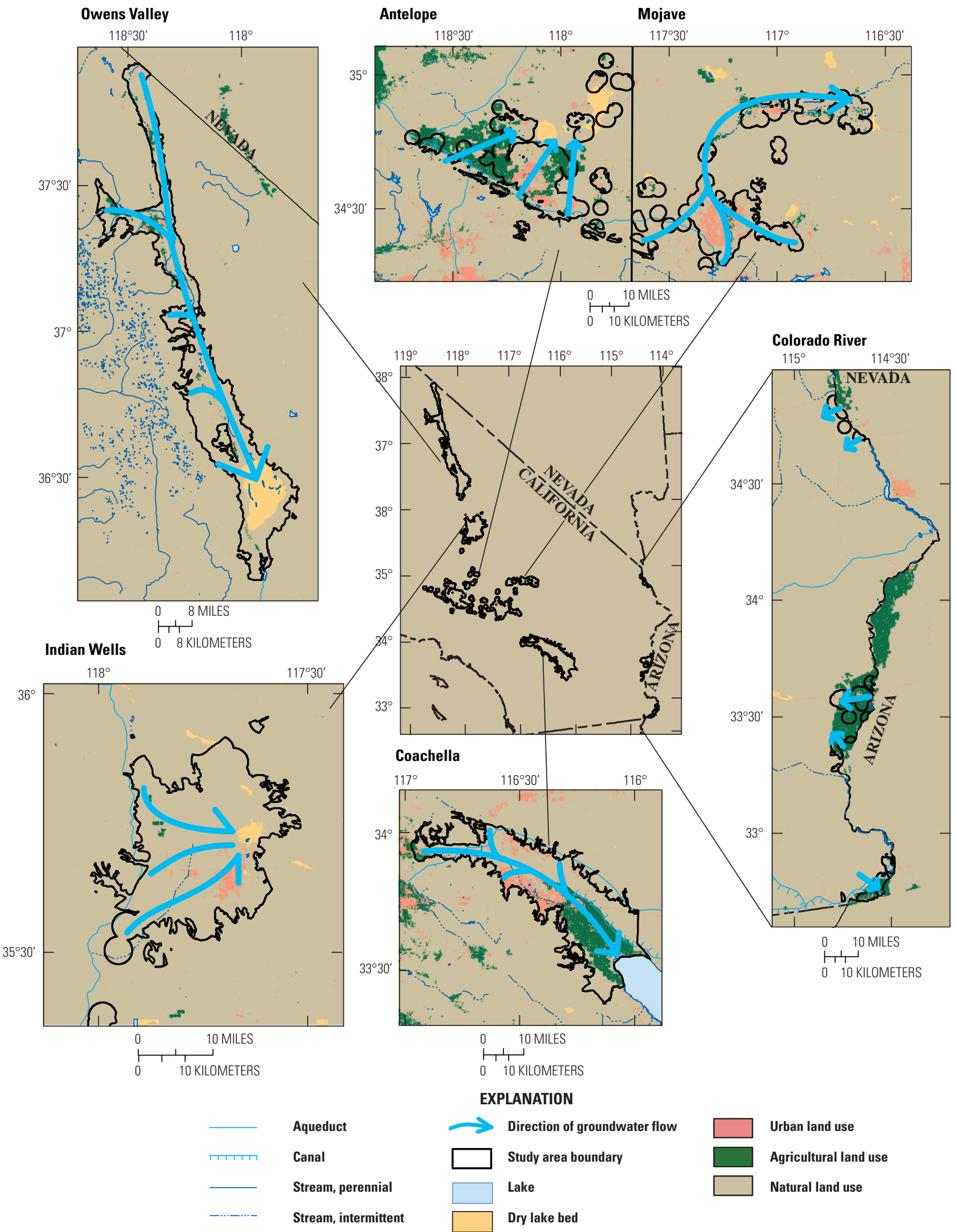

Figure 5. Generalized directions of groundwater flow in the California Desert Region Groundwater Ambient Monitoring and Assessment (GAMA) study areas, 2006-2008. 


\section{Methods}

The status assessment was designed to provide a spatially unbiased assessment of untreated groundwater quality in the primary aquifer systems. This section describes the methods used for (1) defining levels of groundwater quality, (2) assembling the datasets used for the assessment, (3) determining which constituents will be discussed in this assessment, and (4) calculating aquifer-scale proportions for particular constituents or classes of constituents.

The primary metric for defining levels of groundwater quality in this report is relative concentration (RC), which compares groundwater chemistry to regulatory and nonregulatory benchmarks used to evaluate drinking-water quality. A subset of constituents was selected for this assessment on the basis of objective criteria using these RCs. Groundwater-quality data collected by the USGS for the GAMA Program (USGS-GAMA) and data compiled in the CDPH database were used in the status assessment. Two statistical methods based on spatially unbiased grids with equal-area cells in each study area were used to calculate aquifer-scale proportions (Belitz and others, 2010): (1) the "grid-based" method, which uses one value per cell to represent groundwater quality, and (2) the "spatially weighted" method, which uses all available values per cell.

The CDPH database contains historical records from more than 25,000 wells, necessitating targeted retrievals to effectively access water-quality data. The CDPH data were used in three ways in the status assessment: (1) to fill in gaps in USGS-GAMA data for the grid-based calculations of aquifer-scale proportions, (2) to identify constituents for inclusion in the status assessment, and (3) to provide most of the data used in the spatially weighted calculations of aquifer-scale proportions. Methods used for selection of CDPH data for these three purposes are described in appendix A.

\section{Relative-Concentrations and Water-Quality Benchmarks}

Concentrations of constituents in the status assessment are presented as RCs:

$$
\text { Relative-concentration }=\frac{\text { Sample concentration }}{\text { Benchmark concentration }}
$$

Relative-concentrations less than 1.0 indicate sample concentrations that are less than the benchmark, and RCs greater than 1.0 indicate sample concentrations greater than the benchmark. The use of RCs standardized to the benchmark of each constituent facilitates comparisons between constituents that have water-quality benchmarks at different concentrations, even for benchmarks that differ by several orders of magnitude.

Regulatory and non-regulatory benchmarks used for drinking water apply to the water that is served to the consumer, not to the untreated groundwater that was analyzed in this study. However, to provide some context for the results, concentrations of constituents measured in the untreated groundwater were compared with benchmarks established by the U.S. Environmental Protection Agency (USEPA) and CDPH (California Department of Public Health, 2008, 2010a, 2010b; U.S. Environmental Protection Agency, 2011), which are listed in appendix B, tables B2A-F. The benchmarks used for each constituent were selected in the following order of priority:

1. Regulatory, health-based CDPH and USEPA maximum contaminant levels (MCL-CA and MCL-US) and action levels (AL-US).

2. Non-regulatory CDPH and USEPA secondary maximum contaminant levels (SMCL-CA and SMCL-US).

For constituents with both recommended and upper SMCL-CA levels, the values for the upper levels were used.

3. Non-regulatory, health-based CDPH notification levels (NL-CA), USEPA lifetime health advisory levels (HAL-US), and USEPA cancer risk-specific doses for 1:100,000 (RSD5-US).

For constituents with multiple types of benchmarks, this hierarchy may not result in selection of the benchmark with the lowest concentration. Additional information on the types of benchmarks and listings of the benchmarks for all constituents analyzed is provided by Densmore and others (2009), Goldrath and others (2009, 2010), Mathany and Belitz (2009), and Schmitt and others (2009).

Toccalino and others (2004), Toccalino and Norman (2006), and Rowe and others (2007) previously used the ratio of measured concentration to a benchmark [either MCLs or Health-Based Screening Levels (HBSLs)] and defined this ratio as the benchmark quotient. Relative-concentrations used in this report are equivalent to the benchmark quotient of Toccalino and others (2004) for constituents with water-quality benchmarks; however, HBSLs were not used in this report because they are not currently used as benchmarks by California drinking-water regulatory agencies. Relative-concentrations can be computed only for constituents with water-quality benchmarks; therefore, constituents lacking water-quality benchmarks were not included in the status assessment.

In this report, RCs of constituents were classified into high, moderate, and low categories: 


\begin{tabular}{lcc}
\hline Category & $\begin{array}{c}\text { Relative-concentrations } \\
\text { for organic and } \\
\text { special-interest } \\
\text { constituents }\end{array}$ & $\begin{array}{c}\text { Relative-concentrations } \\
\text { for inorganic } \\
\text { constituents }\end{array}$ \\
\hline High & $>1.0$ & $>1.0$ \\
Moderate & $>0.1$ and $\leq 1.0$ & $>0.5$ and $\leq 1.0$ \\
Low & $\leq 0.1$ & $\leq 0.5$ \\
\hline
\end{tabular}

The boundary between moderate and low RCs was set at 0.1 for organic and special-interest constituents for consistency with other studies and reporting requirements (U.S. Environmental Protection Agency, 1998; Toccalino and others, 2004). In a national survey of water quality in aquifers used for public drinking-water supply, Toccalino and others (2004) found that organic constituents (pesticides and VOCs) were detected at high or moderate benchmark quotients $(>0.1)$ in about 10 percent of samples and that, in contrast, inorganic constituents (trace elements and radioactive constituents) were detected at high or moderate benchmark quotients in about 80 percent of samples. Therefore, to provide an indication of the potential groundwater contamination issues that are of the highest and most immediate concern, the boundary between "moderate" and "low" RCs was set at 0.5 for inorganic constituents in this report.

Concentrations of the man-made organic constituents may change rapidly in groundwater; thus, early warning is vital for planning and implementing measures to protect aquifer systems from further contamination and to mitigate existing contamination. Inorganic constituents generally are naturally occurring in groundwater, and their concentrations generally are stable or change slowly compared to concentrations of organic constituents; thus, early warning of potential groundwater contamination may be less critical for management of potential water-quality problems. By choosing a boundary between low and moderate RCs (or benchmark quotient) that is greater than 0.1, inorganic constituents can be identified from among the many that may be present at concentrations approaching benchmarks that may warrant more immediate attention from water-resource managers.

\section{Data Used for Status Assessment}

Two datasets were used in the status assessment: data from wells sampled by the USGS for the GAMA PBP, and data from the CDPH database. Each dataset is described and summarized here, with a discussion comparing the USGS and $\mathrm{CDPH}$ sources presented in appendix C.

\section{Grid Values: USGS Data}

The primary data used for the grid-based calculations of aquifer-scale proportions were data from grid wells sampled by USGS-GAMA. Detailed descriptions of the methods used to identify samples and wells are given in Densmore and others (2009), Goldrath and others (2009, 2010), Mathany and Belitz (2009), and Schmitt and others (2009). Briefly, each study area was divided into equal-area grid cells; one well was randomly selected to represent each cell (Scott, 1990). Wells were selected from the population of wells in statewide databases maintained by CDPH and USGS.

The six Desert study areas contained 251 grid cells, and the USGS sampled wells in 200 of those cells (USGS-grid wells). Of the 200 USGS-grid wells, 159 were public-supply wells also listed in the CDPH database. The other 41 USGS-grid wells were domestic, irrigation, monitoring, industrial, aquaculture, commercial, and recreation-use wells perforated at depths similar to the depths of CDPH wells in the specified cell or neighboring cells. USGS-grid samples were named with an alphanumeric GAMA_ID consisting of a prefix identifying the study area and a number indicating the order of sample collection (fig. B1A-F, table B1). In the Desert Region, the following prefixes were used to indicate study areas: ANT, Antelope Valley study area; COA, Coachella study area; COL, Colorado River study area; IW, Indian Wells study area; MOJ, Mojave study area; and OV, Owens Valley study area.

Groundwater samples collected from USGS-grid wells were analyzed for up to 207 constituents (tables B2A-F). VOCs, pesticides, tritium, noble gases, perchlorate, and stable isotopes of hydrogen and oxygen were analyzed in water samples from all wells. Major and minor inorganic ions, trace elements, and nutrients were analyzed in samples from most wells, and radiochemical constituents, carbon isotopes, and NDMA were analyzed in samples from some wells. The sample-collection methods, analysis methods, and qualitycontrol data for the constituents listed in tables B2A-F are described by Densmore and others (2009), Goldrath and others (2009, 2010), Mathany and Belitz (2009), and Schmitt and others (2009).

\section{Grid Values: CDPH Data}

Of the 251 grid cells in the 6 study areas, 51 cells did not have a USGS-grid sample, 71 cells had a USGS-grid sample but did not have USGS data for major ions, trace elements, nutrients, and radiochemical constituents, and 129 cells had a USGS-grid sample but did not have USGS data for radiochemical constituents. The CDPH database was queried to identify wells that could provide the missing inorganic and radiochemical data. CDPH wells with samples collected within 3 years of the USGS-GAMA sampling periods were considered (table 1 ). If more than one analysis for a constituent in a well was available in the 3-year interval, then the most recent data were selected. Using this method, an additional 15 grid cells were populated with data from the CDPH database, and USGS data were supplemented with CDPH data in 89 grid cells. 
Table 1. Historical and current periods of record available in the California Department of Public Health database in the California Desert Region Groundwater Ambient Monitoring and Assessment (GAMA) study areas.

\begin{tabular}{lcc}
\hline \multicolumn{1}{c}{ Study area } & $\begin{array}{c}\text { Full period of record } \\
\text { available for use in this report }\end{array}$ & $\begin{array}{c}\text { Current period } \\
\text { (3-year interval prior to } \\
\text { USGS-GAMA sample collection) }\end{array}$ \\
\hline Owens Valley and Indian Wells & $08-15-1980$ to 09-11-2006 & $09-11-03$ to 09-11-06 \\
Coachella & $01-04-1984$ to 02-25-2007 & $02-25-04$ to 02-25-07 \\
Colorado River & $03-04-1982$ to 01-11-2006 & $01-11-03$ to 01-11-06 \\
Antelope Valley & $05-02-1980$ to 01-27-2008 & $01-27-05$ to 01-27-08 \\
Mojave & $04-04-1983$ to 02-30-2008 & $02-03-05$ to 02-03-08 \\
\hline
\end{tabular}

The decision tree used to identify suitable CDPH samples is described in detail in appendix A. Briefly, the first choice was to use CDPH data from the same well that was sampled by the USGS ("DG” CDPH-grid samples; fig. B1, table B1). If the CDPH sample did not have all of the needed data or if there was no well sampled by the USGS, another well was randomly selected from the CDPH database if it had data for the missing constituents ("DPH" CDPH-grid samples). No more than one CDPH-grid sample was selected for each cell. The combination of the USGS-grid data and the CDPH-grid data produced a grid-data network covering 215 of the 251 grid cells in the 6 study units.

The CDPH database generally did not contain data for all of the missing inorganic constituents for every CDPH-grid sample; therefore, the number of values used for the gridbased assessment differed for various inorganic constituents (table 2). Although other organizations also collect waterquality data, the CDPH database is the only statewide database of groundwater-chemistry data available during this study for comprehensive analysis.

CDPH data were not used to supplement USGS-grid data for VOCs, pesticides, or perchlorate for the status assessment. A larger number of VOCs and pesticide compounds were analyzed for the USGS-GAMA Program than are available from the CDPH database. USGS-GAMA collected data for 84 VOCs and 64 pesticides and pesticide degradates at every well (tables B2A and B2B). Laboratory reporting levels used for USGS-GAMA analyses of organic constituents typically were one to two orders of magnitude lower than the reporting levels used for analyses compiled by the CDPH.

\section{Selection of Constituents for Status Assessment}

As many as 207 constituents were analyzed in groundwater samples from the Desert study areas; however, only a subset of these constituents is evaluated in this report. Three criteria were used to select constituents for further analysis in the status assessment:
1. Constituents detected at high or moderate RCs in the CDPH database within the 3-year intervals prior to USGS-GAMA sampling periods,

2. Constituents detected at high or moderate RCs in the USGS-grid wells or USGS-understanding wells used in the status assessment, or

3. Organic constituents with detection frequencies greater than 10 percent in the USGS-grid well dataset for a particular study unit.

These criteria resulted in the identification of 14 inorganic constituents and 3 organic constituents for further evaluation in the status assessment. An additional 43 organic constituents and 36 inorganic constituents were detected by USGS-GAMA and were not selected for further evaluation in the status assessment because they either have no established benchmarks, or they were only detected at low RCs. The remaining constituents that were not detected by USGS-GAMA in any of the six study units are listed in Densmore and others (2009), Goldrath and others (2009, 2010), Mathany and Belitz (2009), and Schmitt and others (2009).

The CDPH database also was used to identify constituents that have been reported at high RCs historically. The historical period was defined as the earliest record maintained in the CDPH database to just prior to the 3-year intervals used for the status assessments. Constituent concentrations in the CDPH database may have decreased from historically high values because of improvement in groundwater quality or because of abandonment of wells with high concentrations. Historically high constituent concentrations in wells in the Desert Region are shown in table 3. Constituents with high concentrations only in the historical time period (and that were not detected at high concentrations in current samples) did not meet the criteria for further evaluation in the status assessment and are not considered representative of current concerns about groundwater quality in the study areas. 


\begin{tabular}{|c|c|c|c|c|c|}
\hline \multirow{2}{*}{ 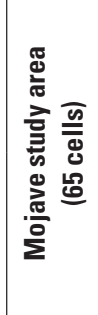 } & 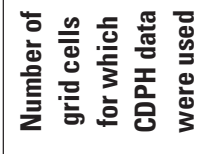 & & 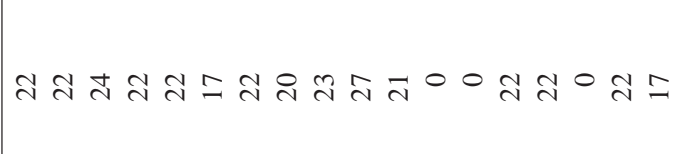 & & 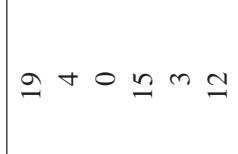 \\
\hline & 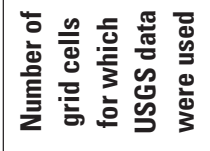 & & 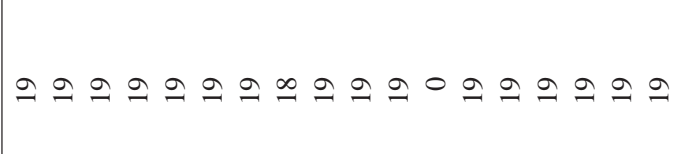 & & $\stackrel{\neg}{\rightarrow} 9 \stackrel{\neg}{\rightarrow} 9$ \\
\hline \multirow{2}{*}{ 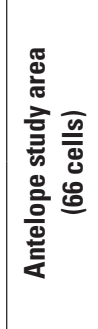 } & 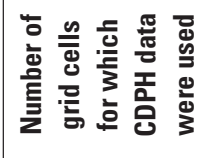 & & 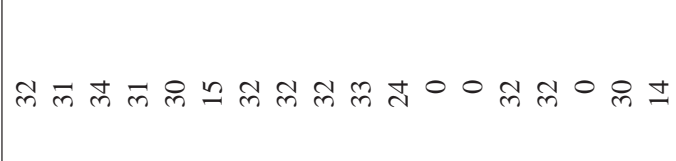 & & 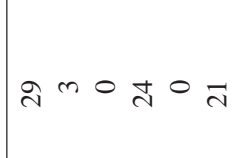 \\
\hline & 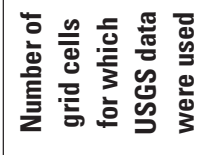 & & $\stackrel{\infty}{\sim} \stackrel{\infty}{\sim} \stackrel{\infty}{\sim} \stackrel{\infty}{\sim} \stackrel{\infty}{\sim} \stackrel{\infty}{\sim} \stackrel{\infty}{\sim} \stackrel{\infty}{\sim} \stackrel{\infty}{\sim} \stackrel{\infty}{\sim} \stackrel{\infty}{\sim} \sim \stackrel{\infty}{\sim} \stackrel{\infty}{\sim} \stackrel{\infty}{\sim} \stackrel{\infty}{\sim} \stackrel{\infty}{\sim} \stackrel{\infty}{\sim}$ & & $\stackrel{\infty}{\sim} \stackrel{\infty}{\sim} \stackrel{\infty}{\sim} \stackrel{\infty}{\sim} \stackrel{\infty}{\sim} \stackrel{\infty}{\sim}$ \\
\hline \multirow{2}{*}{ 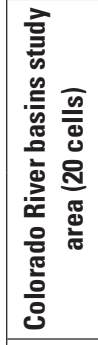 } & 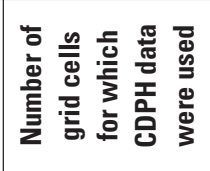 & & 000000000000000000 & & 000000 \\
\hline & 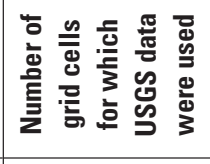 & & 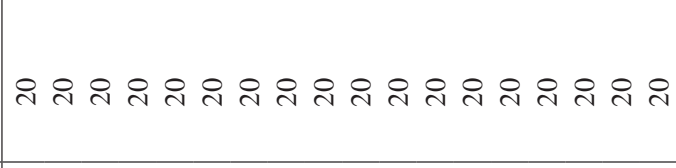 & & ㄱ กิ ฉ \\
\hline \multirow{2}{*}{ 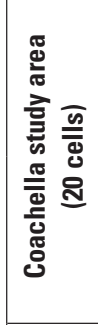 } & 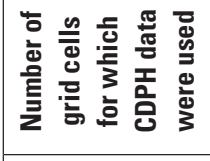 & & $00000000000 m 000000$ & & $\rightarrow 00 \rightarrow 00$ \\
\hline & 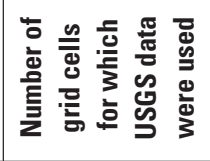 & & 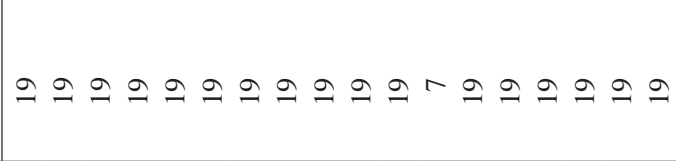 & & $\wedge \wedge \wedge \wedge \curvearrowleft$ \\
\hline \multirow{2}{*}{ 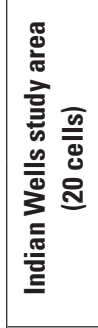 } & 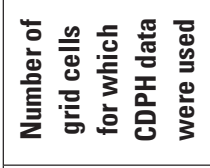 & & 000000000000000000 & & $000+00$ \\
\hline & 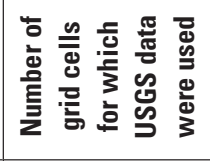 & & 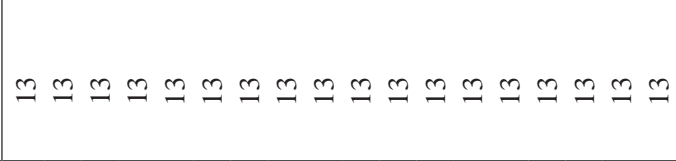 & & 00000009 \\
\hline \multirow{2}{*}{ 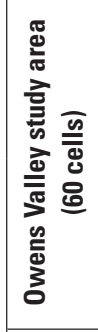 } & 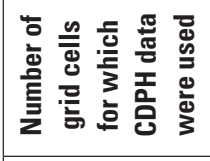 & \multirow{3}{*}{ 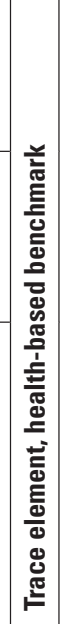 } & 000000000000000000 & & $\stackrel{\neg}{\forall} \wedge 000$ \\
\hline & 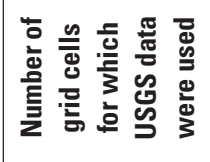 & & 种 $q$ q $q$ q $q$ q $q$ q $q$ q $q$ q $q$ q $q$ q & \multirow{2}{*}{ 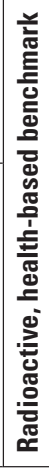 } & $\wedge \wedge \wedge \wedge \curvearrowleft q$ \\
\hline & $\begin{array}{l}\text { 䓂 } \\
\text { 蒂 } \\
\text { 产 }\end{array}$ & & 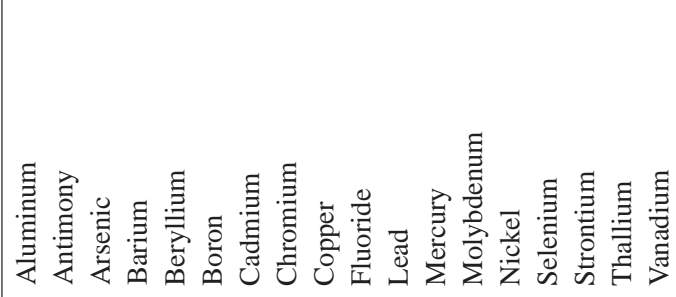 & & 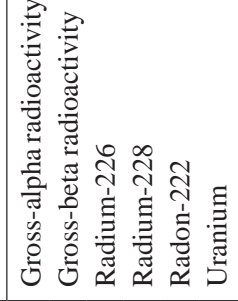 \\
\hline
\end{tabular}




\begin{tabular}{|c|c|c|c|c|c|}
\hline \multirow{2}{*}{ 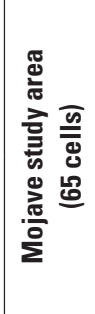 } & 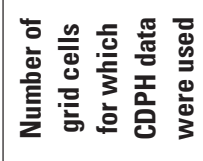 & & 0 मे & & 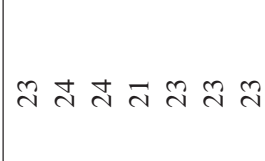 \\
\hline & 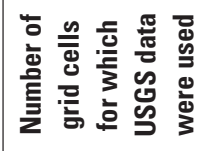 & & $\rightarrow 9$ & & 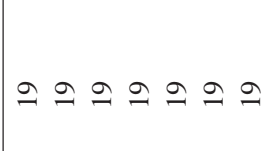 \\
\hline \multirow{2}{*}{ 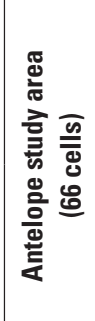 } & 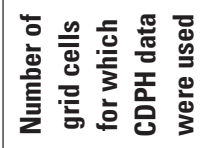 & & $m$ c్ల & & $\ddot{m} \approx \tilde{m} \tilde{m} \vec{m} \tilde{m} \tilde{m} \tilde{m}$ \\
\hline & 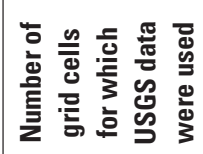 & & $\stackrel{\infty}{\sim} \stackrel{\infty}{\sim} \stackrel{\infty}{\sim}$ & & $\stackrel{\infty}{\sim} \stackrel{\infty}{\sim} \stackrel{\infty}{\sim} \stackrel{\infty}{=} \stackrel{\infty}{=} \stackrel{\infty}{\sim} \stackrel{\infty}{\sim}$ \\
\hline \multirow{2}{*}{ 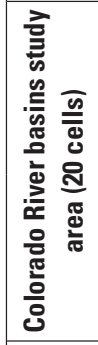 } & 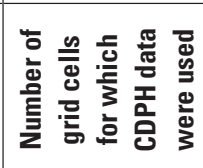 & & $\begin{array}{lll}0 & 0 & 0\end{array}$ & & 0000000000 \\
\hline & 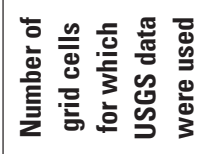 & & กิ ฉి ని & & 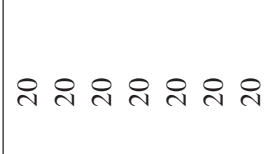 \\
\hline \multirow{2}{*}{ 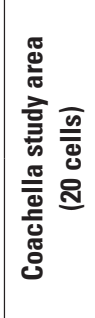 } & 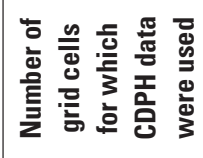 & & $0 \begin{array}{lll}0 & 0 & 0\end{array}$ & & 00000000 \\
\hline & 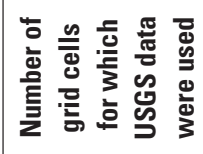 & & 99 & & 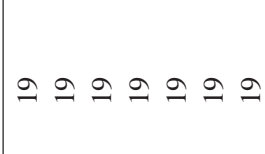 \\
\hline \multirow{2}{*}{ 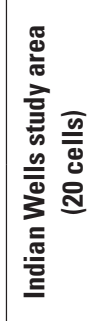 } & 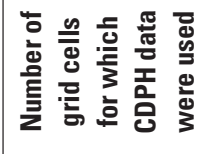 & & 000 & & 00000000 \\
\hline & 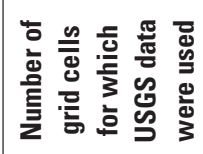 & & $\stackrel{M}{\rightarrow} \stackrel{m}{\rightarrow}$ & & 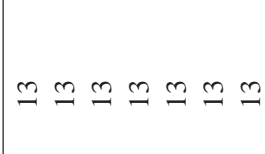 \\
\hline \multirow{2}{*}{ 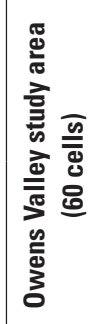 } & 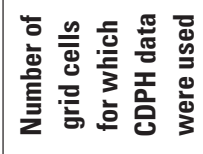 & & 000 & 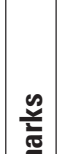 & 000000000 \\
\hline & 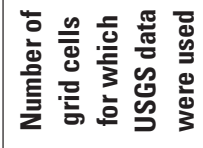 & \multirow[b]{2}{*}{ 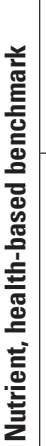 } & $q$ q $q$ & 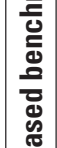 & q $q$ q $q$ q $q$ \\
\hline & 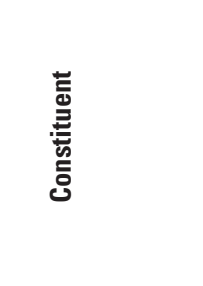 & & 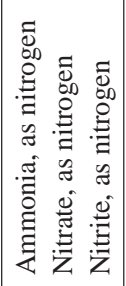 & 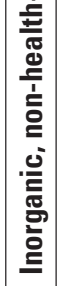 & 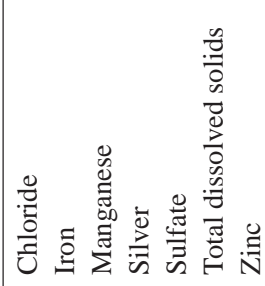 \\
\hline
\end{tabular}



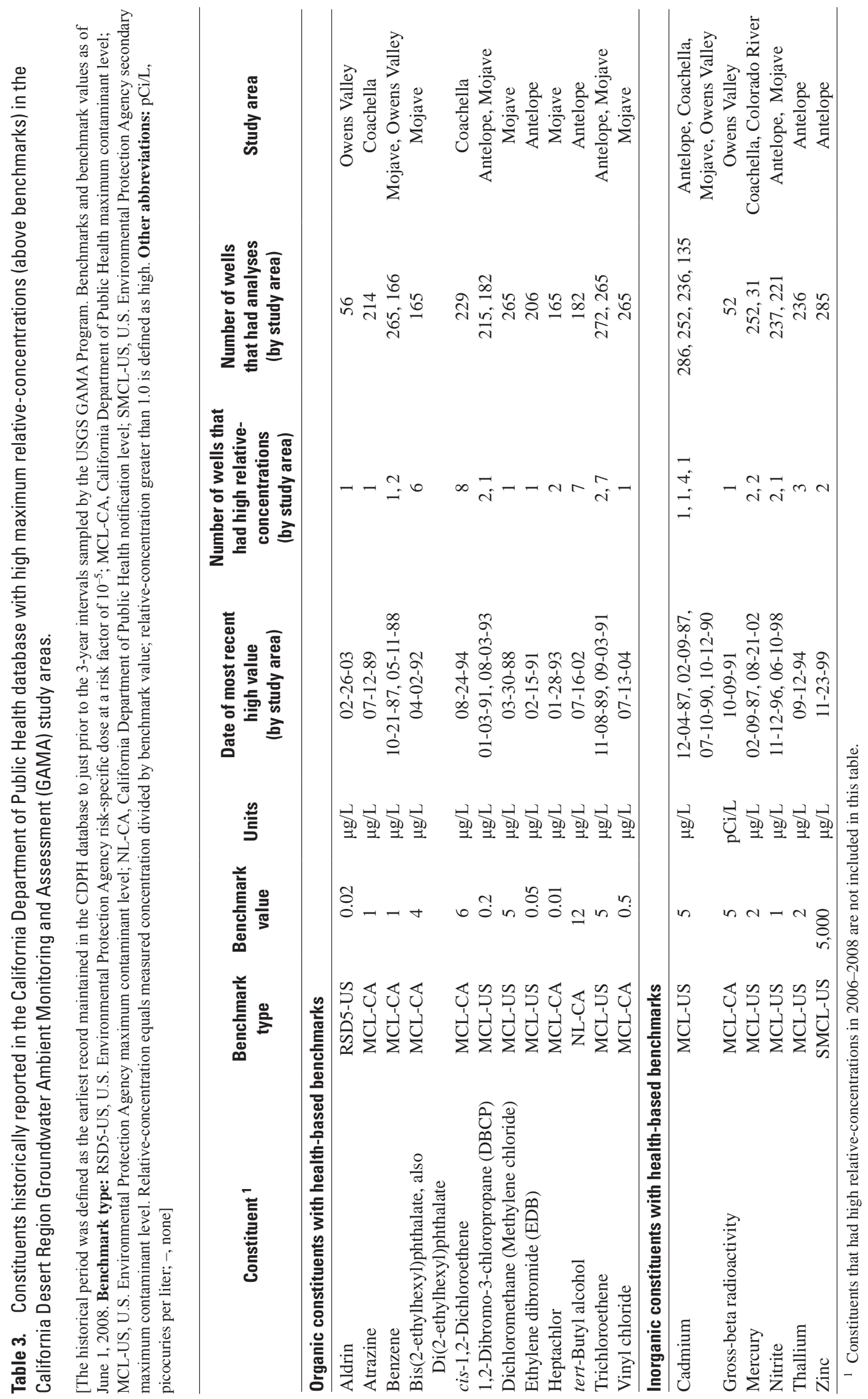


\section{Calculation of Aquifer-Scale Proportions}

Aquifer-scale proportions are defined as the percentage of the area (rather than the volume) of the primary aquifer system with concentrations greater than or less than specified thresholds relative to water-quality benchmarks. This status assessment is intended to characterize the quality of groundwater resources in the primary aquifers of the Desert Region study areas. The primary aquifers are defined by the depth intervals over which wells listed in the CDPH database are perforated. The use of the term "primary aquifer" does not imply that there is a single discrete aquifer unit. The primary aquifer corresponds to the portion of the aquifer system tapped by municipal and community supply wells. To the extent that domestic wells in the six study areas are perforated over the same depth intervals as the CDPH wells, the assessments presented in this report also may be applicable to the portions of the aquifer systems used for domestic drinking-water supplies.

Two approaches, grid-based and spatially weighted (Belitz and others, 2010), were selected to determine the areal proportions of the primary aquifers in the six study areas with high and moderate RCs of constituents. These proportions are referred to as "high" and "moderate" aquifer-scale proportions. Calculations of aquifer-scale proportions were made for individual constituents meeting the criteria for inclusion in the status assessment and for classes of constituents. Classes of constituents with health-based benchmarks included VOCs, pesticides, special-interest constituents, any organic constituent (combination of all VOCs, pesticides, and organic special-interest constituents), radioactive constituents, trace elements, nutrients, and any inorganic constituent (combination of all radioactive constituents, trace elements, nutrients, and inorganic special-interest constituents).

\section{Grid-Based Aquifer-Scale Proportions}

The grid-based calculation used the grid-well dataset assembled from the USGS-grid and CDPH-grid samples as described in the section "Data Used for Status Assessment." For each constituent, the high aquifer-scale proportion was calculated by dividing the number of cells with a high RC for that constituent by the total number of grid cells with data for that constituent. The moderate aquifer-scale proportion was calculated similarly for each constituent. Confidence intervals for the high aquifer-scale proportions were computed using the Jeffreys interval for the binomial distribution (Brown and others, 2001; Belitz and others, 2010). The grid-based estimate is designed to be spatially unbiased. However, the grid-based approach may not detect constituents that are present at high concentrations in small proportions of the primary aquifers. Additionally, estimates of aquifer-scale proportion for constituents based on a smaller number of wells have a larger error associated with the 90 percent confidence intervals.
For classes of constituents, the high aquifer-scale proportion was calculated by dividing the number of cells with a high concentration for any of the constituents in that class by the total number of cells with data for that class of constituents. The moderate aquifer-scale proportion was calculated by dividing the number of cells with a moderate concentration for any of the constituents (not counting cells that also had high concentrations) by the total number of cells with data for that class of constituents.

\section{Spatially Weighted Aquifer-Scale Proportions}

The spatially weighted calculation used a larger, non-gridded dataset assembled from CDPH and USGS samples, including 53 additional samples collected by USGS-GAMA, and all wells in the CDPH database that have water-quality data from the 3-year intervals prior to USGSGAMA sampling periods (for wells with USGS and CDPH data, only the USGS data were used). For each constituent, the high aquifer-scale proportion was calculated by computing the proportion of "high" wells in each cell and then averaging together the proportions for all cells for a particular study unit (Isaaks and Srivastava, 1989). The resulting proportions are spatially unbiased (Isaaks and Srivastava, 1989). Confidence intervals for spatially weighted estimates of aquifer-scale proportion are not described in this report. The moderate aquifer-scale proportion was calculated similarly.

For the calculation of high aquifer-scale proportion for a class of constituents, a class was considered high if the RC of any constituents in that class was high in any sample. A class was considered moderate if the RC of any constituent in that class was moderate for any sample and if the RC of none of the constituents was high.

\section{Raw Detection Frequencies}

In addition, for each constituent, the raw detection frequencies (number of detections above a specified concentration divided by number of analyses) for high and moderate RCs were calculated using the same dataset as was used for the spatially weighted calculations. However, these raw detection frequencies are not spatially unbiased because the wells in the CDPH database are not uniformly distributed (figs. 4A-H). For example, if a constituent was present at high RCs in a small region of the aquifer with a high density of wells, the raw detection frequency of high RCs would be greater than the grid-based high aquifer-scale proportion. Raw detection frequencies are provided for reference but were not used to assess aquifer-scale proportions.

\section{Area Correction Factors}

For the calculation of the grid-based and spatially weighted aquifer proportions for the entire Desert Region, an area correction factor was applied to the results of the 
individual study areas. This was done so that results from the smaller study areas would not be over-represented when combined with results from the larger study areas. The correction factors were calculated as the area of each study area, defined as the area covered by grid cells, divided by the sum of all grid cell areas in all of the study areas. These area correction factors were as follows: Owens Valley, 0.22; Antelope, 0.19; Mojave, 0.18; Coachella, 0.23; Colorado River, 0.06; Indian Wells, 0.13. Area correction factors for NDMA, which was not analyzed for in all six study areas, were calculated using a similar process for only the four study areas where samples were analyzed for NDMA. Similarly, area correction factors for radon-222 were calculated for the five study areas where samples were collected for radon-222 analysis.

Inorganic consituents with health-based benchmarks Number of constituents: 29

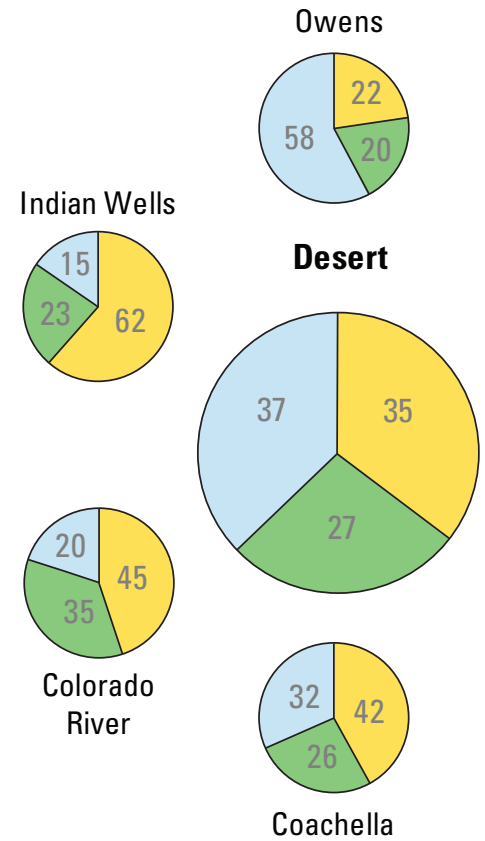

Antelope

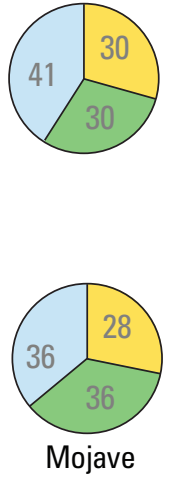

\section{EXPLANATION}

\section{Status of Groundwater Quality}

The RCs for the inorganic and organic constituent classes for grid samples for the Desert Region as a whole and in each study area are shown in figure 6. The maximum RCs in grid wells for each detected constituent in the Desert Region are shown in figure 7; the results for the individual study areas are shown in figures B2 and B3. As shown in all of these figures, there is a large contrast between the inorganic constituents compared to organic constituents. For the inorganic classes, a larger proportion of the aquifers in each study area and a higher number of constituents had high or moderate RCs; for organic classes, much smaller proportions of the aquifers and fewer constituents had high or moderate RCs. Organic constituents with health-based benchmarks
Number of constituents: 78

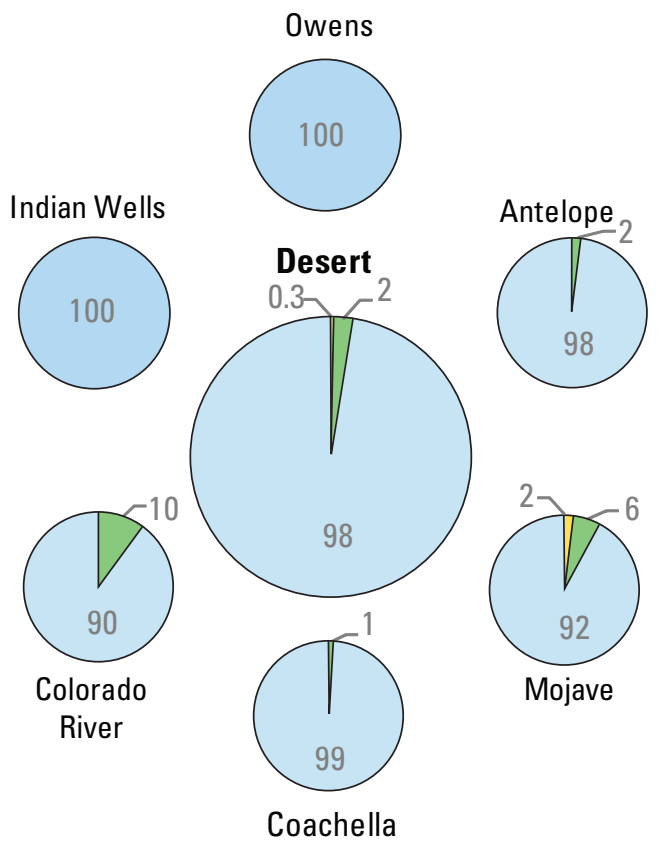

\footnotetext{
Aquifer-scale proportions Values on pie chart may not equal 100 due to rounding of percentages

Moderate - No constituents in any grid well had high relative-concentrations, and at least one constituent had a moderate relative-concentration, between 0.1 (for organic and special-interest constituents) or 0.5 (for inorganic constituents) and 1.0 of their respective benchmarks
}

Pie charts illustrate the proportions of the primary aquifers with concentrations in specified categories.

High - At least one constituent in any grid well had a high relative-concentration, greater than 1.0 of their respective benchmarks
Low or not detected - No constituents in any grid well had high or moderate relativeconcentrations; all concentrations were below 0.5 (for inorganic constituents) or below 0.1 (for organic and special-interest constituents) of their respective benchmarks

Figure 6. Aquifer-scale proportions for inorganic and organic constituent classes in the California Desert Region as a whole and for the individual California Desert Region Groundwater Ambient Monitoring and Assessment (GAMA) study areas, 2006-2008. 


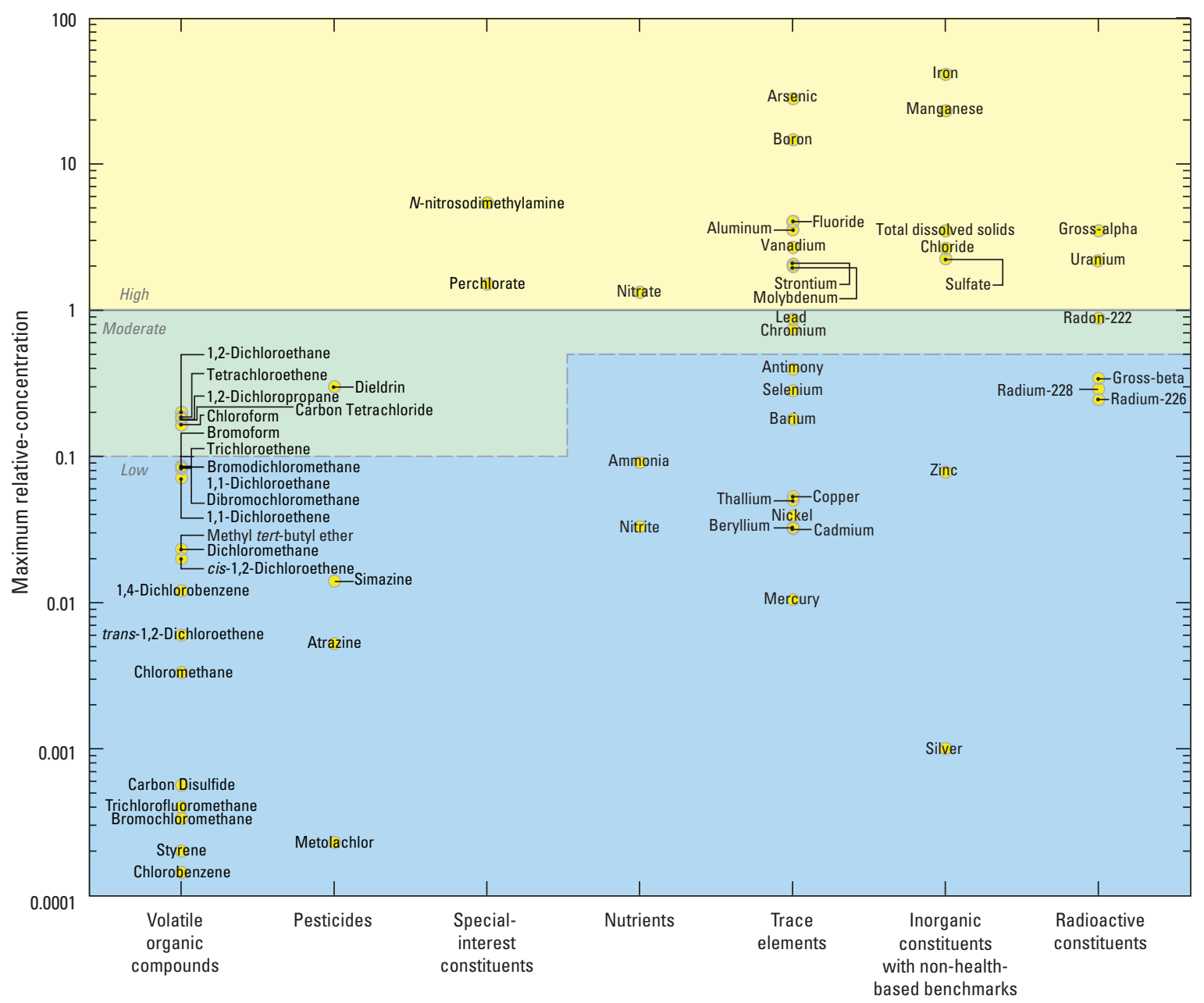

Figure 7. Maximum concentrations relative to health-based and non-health-based benchmarks in grid wells for classes of constituents detected in the California Desert Region Groundwater Ambient Monitoring and Assessment (GAMA) study areas, 2006-2008.

Of the 149 organic constituents analyzed in the Desert Region, 78 have a health-based benchmark. Forty-two organic constituents were detected, most of which (32 of the 42) have health-based benchmarks (tables 4 and $\underline{B 2 A-B 2 C}$ ). Of the 10 detected constituents that did not have benchmarks, two (desethylatrazine and 3,4-dichloroanaline) are possible degradates of pesticides (atrazine and diuron) that do have benchmarks. The other detected organic constituents that did not have benchmarks were four solvents (chloroethane, chloromethane, dibromomethane, and tetrahydrofuran), two herbicides (prometryn and terbuthylazine), and an insecticide and two of its degradation products (fipronil, desulfinylfipronil, and fipronil sulfide).

In contrast to organic constituents, all inorganic constituents (48 of 48) analyzed in the Desert Region were detected in at least one study area (tables 4 and B2C-B2F). Twenty-nine of these inorganic constituents have health-based benchmarks. Most of the constituents without benchmarks are major or minor ions that are present naturally in most groundwater.
The inorganic constituents that were detected in grid wells at high concentrations relative to health-based thresholds in the Desert Region are arsenic, boron, fluoride, aluminum, gross-alpha radioactivity, molybdenum, nitrate, strontium, uranium, and vanadium (fig. 7; table 5). The inorganic constituents that were detected in grid wells at high concentrations relative to non-health-based thresholds are chloride, iron, manganese, sulfate, and total dissolved solids (TDS) (fig. 7; table 5). No VOC or pesticide constituents were detected at high RCs in grid wells in any of the Desert Region study areas; however, the VOCs carbon tetrachloride (tetrachoromethane), chloroform (trichloromethane), 1,2-dichloropropane, 1,2-dichloroethane, and tetrachloroethene and the pesticide dieldrin were detected at moderate RCs. The special-interest constituents perchlorate and NDMA were detected at high RCs in one or more of the USGS-grid wells.

Spatially weighted high aquifer-scale proportions fell within the 90 percent confidence intervals for their respective grid-based high aquifer-scale proportions, showing that the grid-based and spatially weighted approaches yield statistically equivalent results (table 5). 

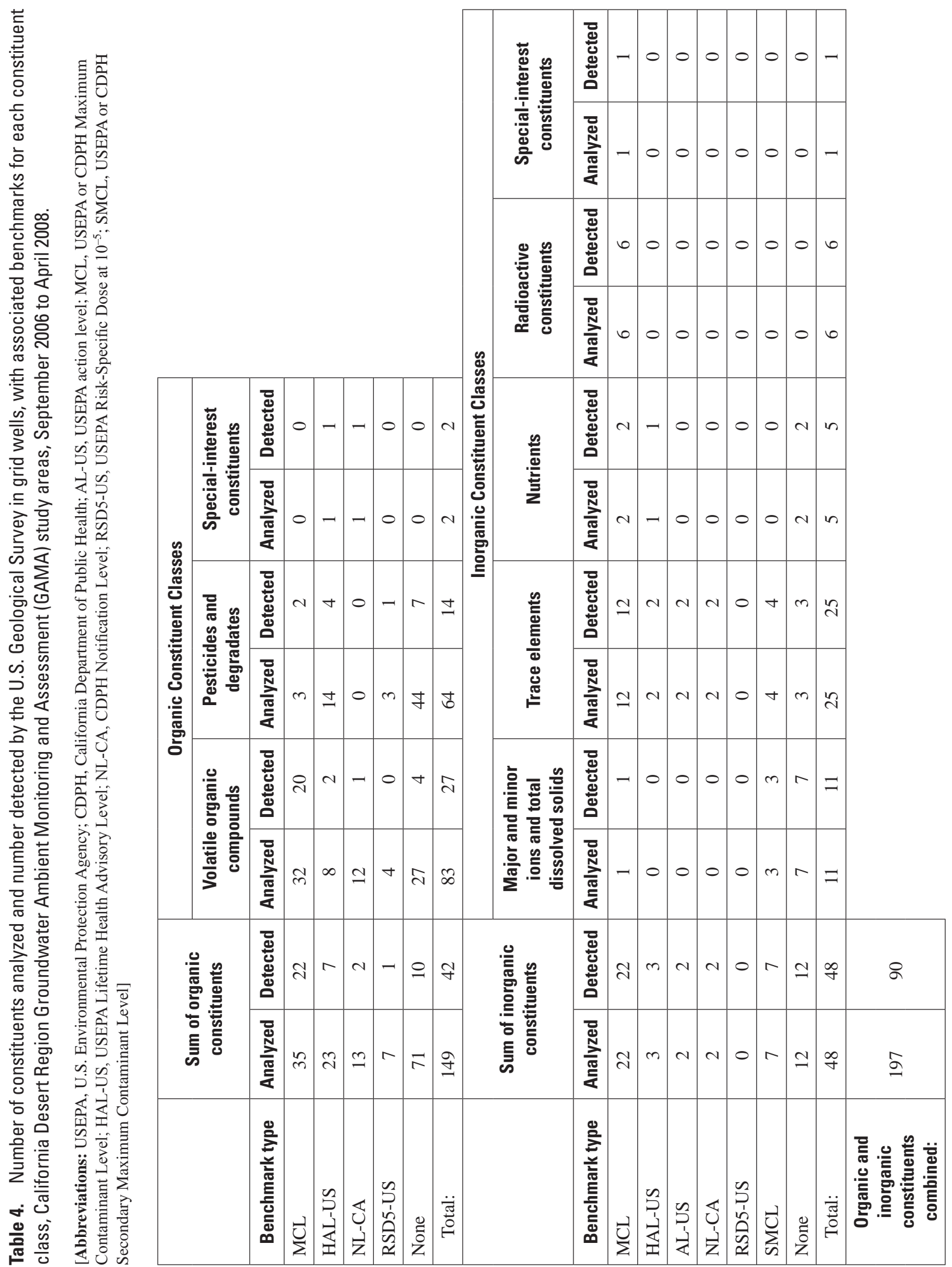


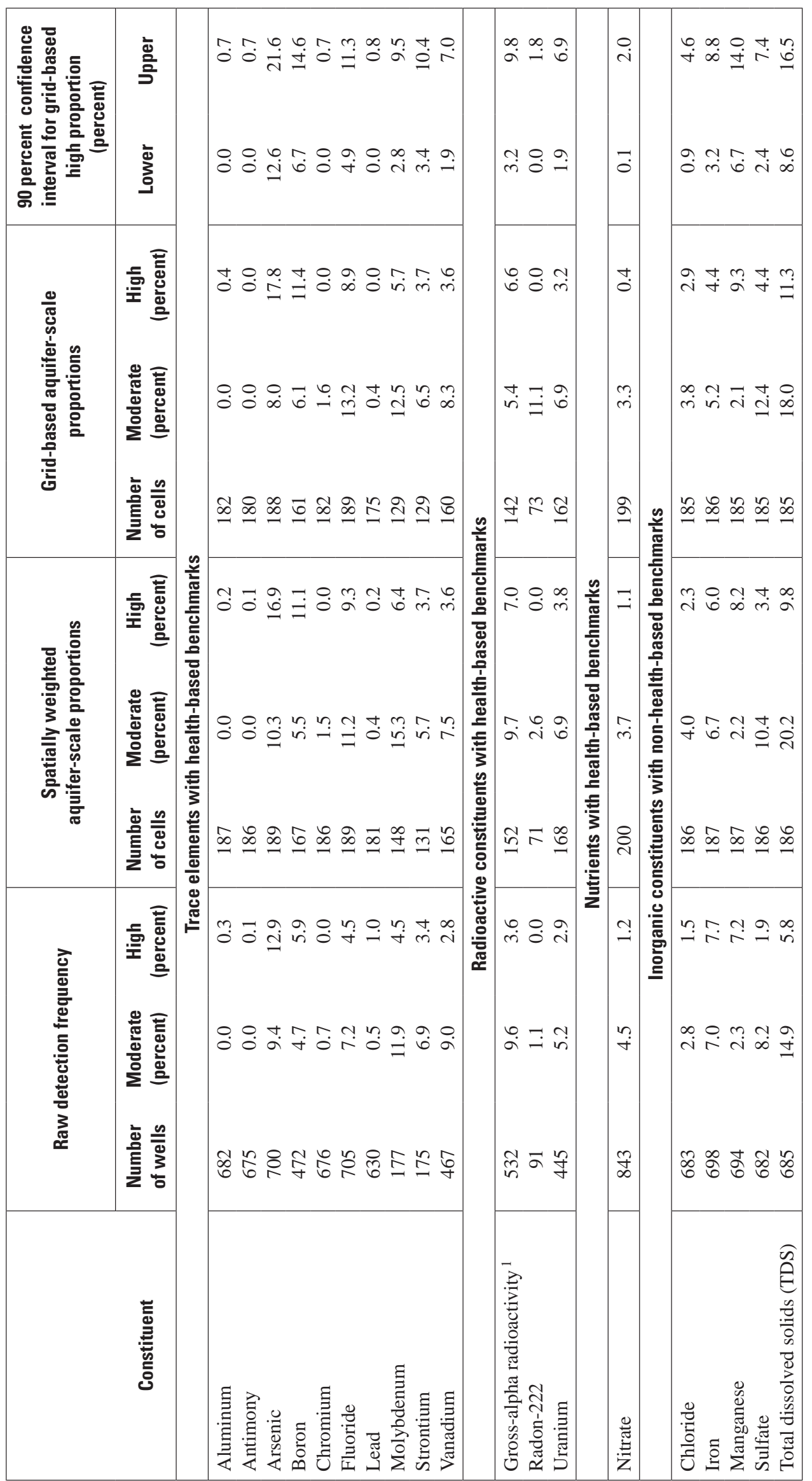



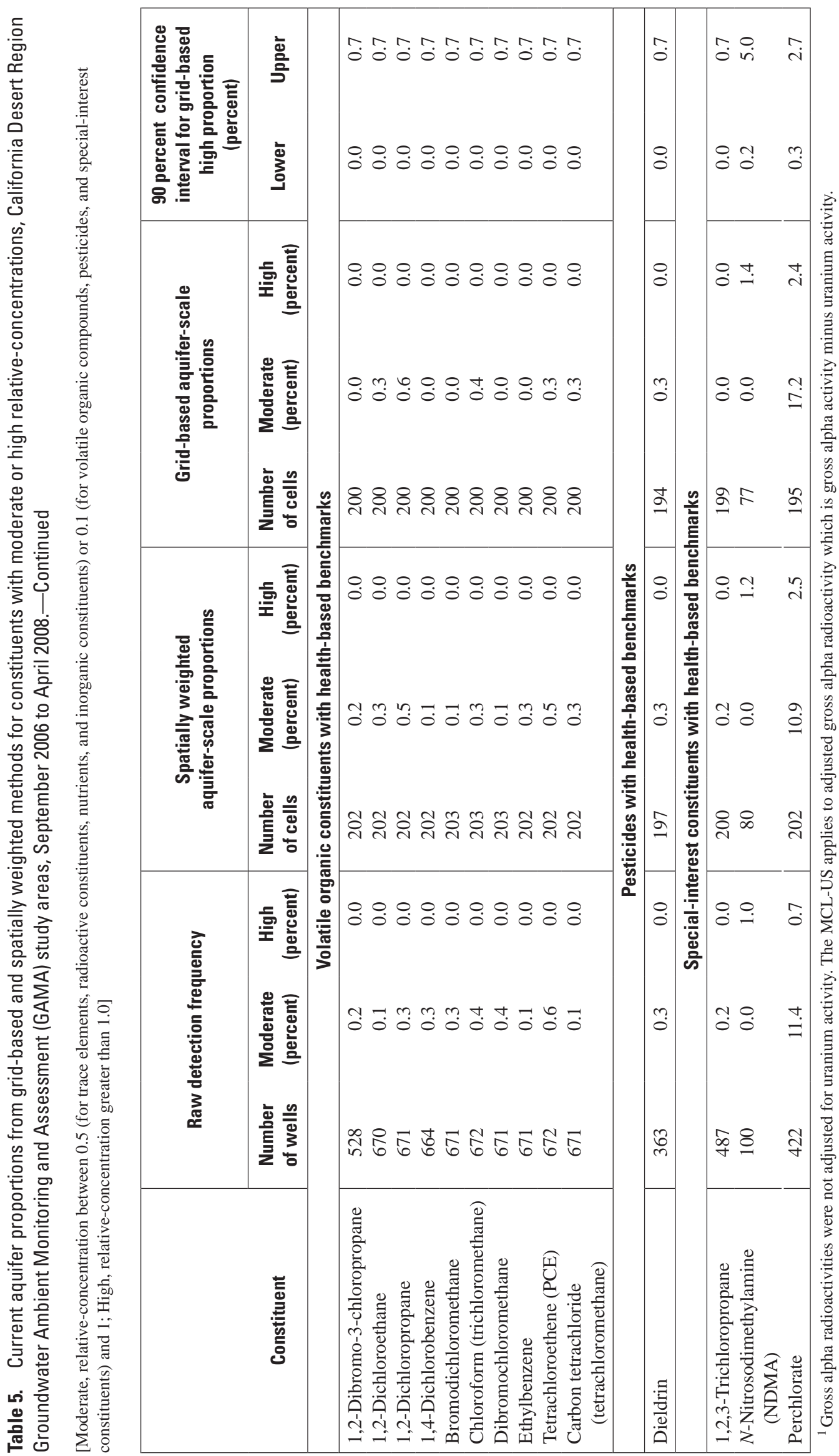


\section{Inorganic Constituents}

Data for 48 inorganic constituents were used for this study (11 major or minor ions, 25 trace elements, 5 nutrients, 6 radioactive constituents, and 1 special-interest constituent). All 48 inorganic constituents were detected at least once in the Desert Region (table 4). Of these, 29 have health-based benchmarks, and 7 have non-health-based benchmarks.

Eighteen inorganic constituents-arsenic, boron, chloride, chromium, fluoride, gross-alpha radioactivity, iron, lead, molybdenum, manganese, nitrate, perchlorate, radon222, strontium, sulfate, uranium, vanadium, and TDS — had moderate RCs in the grid-based aquifer proportions (table 5). Of these, 14 also had high RCs in more than 2 percent of the primary aquifers in the Desert Region (arsenic, boron, chloride, fluoride, gross-alpha radioactivity, iron, molybdenum, manganese, perchlorate, strontium, sulfate, uranium, vanadium, and TDS); maps showing the areal distributions of these constituents are presented later in the report.

\section{Inorganic Constituents with Health-Based Benchmarks}

Inorganic constituents with health-based benchmarks were the constituent class with the largest aquifer proportion of high RCs in the Desert Region. High RCs of one or more inorganic constituents with health-based benchmarks were found in 35.4 percent of the primary aquifers (table 6; fig. 6). Several inorganic constituents with health-based benchmarks were detected at high RCs in each of the Desert Region study areas (appendix B; tables B3A-F). This constituent class had moderate RCs in 27.4 percent of the Desert Region's primary aquifers, and low RCs in 37.2 percent (table 6; fig. 6).

\section{Trace Elements}

Trace elements, as a class, had high RCs for one or more constituents in 32.5 percent of the primary aquifers, moderate RCs in 20.2 percent, and low RCs in 47.3 percent of the Desert Region's primary aquifers (table 6). High RCs of trace elements reflected high arsenic, boron, fluoride, molybdenum, strontium, vanadium, and aluminum (table 5). Two trace elements, chromium and lead, were detected only at moderate RCs. The trace elements antimony and lead were not detected in grid wells, but had spatially weighted, high RCs in 0.1 percent and 0.2 percent of the primary aquifers, respectively; these detections were within the 90 percent confidence intervals for these trace elements for the grid-based approach. The spatially weighted approach includes data from a larger number of wells than used in the grid-based approach and, therefore, is more sensitive to constituents present in very small proportions of the primary aquifers.
Arsenic was detected at high RCs in 17.8 percent of the Desert Region's primary aquifers and at moderate concentrations in 8.0 percent (table 5). All six Desert Region study areas had high-relative concentrations of arsenic (figs. 8 and $\underline{9}$; tables B3A-F). The highest RC was in the ANT study area (fig. 8). The high RCs are distributed throughout some study areas (OV, ANT, and MOJ,), but occur only in parts of other study areas (IW, COA, and COL) (fig. 9).

Boron was detected at high RCs in 11.4 percent of Desert Region grid wells, and at moderate RCs in 6.1 percent (table 5). High RCs of boron occurred in all six study areas (figs. 8 and 10; tables B3A-F). The highest RC was detected in IW (fig. 8). High boron concentrations were found in wells near the downgradient parts of the regional groundwater flow systems (identified in fig. 5) in every study area (fig. 10).

Fluoride was detected at high RCs in 8.9 percent and at moderate RCs in 13.2 percent of the Desert Region's primary aquifers (table 5). It was detected at high RCs in COA, COL, MOJ, OV, and ANT; it was detected at moderate RCs in IW (tables B3A-F). The highest RC was in COA (fig. 8). The distributions of high fluoride concentrations varied in the study areas (fig. 11). In COA, OV, and IW, high and moderate concentrations were found in upgradient and downgradient areas. In ANT and MOJ, high concentrations were mostly in downgradient areas; in COL, high concentrations of fluoride were in the Needles and Palo Verde basins, but not in the Yuma basin.

Molybdenum was detected at high RCs in 5.7 percent and at moderate RCs in 12.5 percent of the primary aquifers in the Desert Region (table 5). It was detected at high RCs in all the study areas except ANT, where it was detected at moderate RCs (figs. 8 and 12; tables B3A-F). The highest RC was in COL (fig. 8). Moderate and high RCs were distributed throughout OV, IW, MOJ, and COA. A high RC was in the Palo Verde basin in COL; moderate RCs were only in downgradient wells in ANT (fig. 12).

Vanadium was detected at high RCs in 3.6 percent of the Desert Region's primary aquifers and at moderate RCs in 8.3 percent (table 5). It was detected at high RCs in MOJ, IW, and ANT; at moderate RCs in COA; and at low RCs in OV and COL (tables B3A-F). The highest RC was in IW; this RC was similar to the highest RCs in ANT and MOJ (fig. 8). The high RCs in IW and MOJ were in the middle or upper parts of the flow systems; in ANT, the highest concentrations were in downgradient wells (fig. 13). Moderate RCs were in the middle and downgradient areas in COA; only low RCs were in $\mathrm{OV}$ and COL.

Strontium was detected at high RCs in 3.7 percent of the Desert Region's primary aquifers and at moderate RCs in 6.5 percent (table 5). It was detected at high RCs in MOJ, COA, IW, and COL, and at low RCs in ANT and OV (fig. 14; tables B3A-F). The highest RC was in MOJ (fig. 14). High and moderate RCs of strontium were generally in the downgradient areas of the groundwater flow systems of the six study areas (fig. 15). 
Table 6. Summary of aquifer-scale proportions for inorganic constituent classes in the California Desert Region Groundwater Ambient Monitoring and Assessment (GAMA) study areas.

[Low, relative-concentration less than 0.5 (or 0.1 for perchlorate); Moderate, relative-concentration between 0.5 (or 0.1 for perchlorate) and 1 ; High, relative-concentration greater than 1.0; Values are grid-based except where footnoted]

\begin{tabular}{|c|c|c|c|c|c|}
\hline Study area & $\begin{array}{l}\text { Number of grid } \\
\text { cells with data }\end{array}$ & \multicolumn{4}{|c|}{ Aquifer-scale proportion (percent) } \\
\hline \multicolumn{6}{|c|}{ Trace elements with health-based benchmarks } \\
\hline Desert Region (all study areas) & 192 & 0.0 & 47.3 & 20.2 & 32.5 \\
\hline Owens Valley & 40 & 0.0 & 72.5 & 12.5 & 15.0 \\
\hline Antelope & 54 & 0.0 & 51.8 & 16.7 & 31.5 \\
\hline Colorado River & 20 & 0.0 & 30.0 & 30.0 & 40.0 \\
\hline Indian Wells & 13 & 0.0 & 15.4 & 30.8 & 53.8 \\
\hline \multicolumn{6}{|c|}{ Radioactive constituents with health-based benchmarks ${ }^{2}$} \\
\hline Desert Region (all study areas) & 182 & 0.0 & 81.9 & 11.1 & ${ }^{1} 7.1$ \\
\hline Owens Valley & 40 & 0.0 & 75.0 & 15.0 & 10.0 \\
\hline Indian Wells & 13 & 0.0 & 76.9 & 7.7 & 15.4 \\
\hline \multicolumn{6}{|c|}{ Nutrient constituents with health-based benchmarks } \\
\hline Desert Region (all study areas) & 199 & 3.0 & 92.8 & 3.4 & ${ }^{1} 0.8$ \\
\hline Owens Valley & 40 & 0.0 & 100.0 & 0.0 & 0.0 \\
\hline Antelope & 54 & 7.3 & 81.5 & 9.3 & 1.9 \\
\hline Mojave & 53 & 3.8 & 94.3 & 1.9 & 0.0 \\
\hline Coachella & 19 & 0.0 & 92.8 & 5.3 & ${ }^{1} 1.9$ \\
\hline Colorado River & 20 & 0.0 & 99.0 & 1.01 & 0.0 \\
\hline Indian Wells & 13 & 7.7 & 92.3 & 0.0 & 0.0 \\
\hline \multicolumn{6}{|c|}{ Inorganic constituents with non-health-based benchmarks } \\
\hline \multicolumn{6}{|c|}{ Special-interest constituent: Perchlorate } \\
\hline Desert Region (all study areas) & 195 & 58.3 & 22.1 & 17.2 & 2.4 \\
\hline Owens Valley & 40 & 97.5 & 2.5 & 0.0 & 0.0 \\
\hline Antelope & 56 & 14.3 & 57.1 & 28.6 & 0.0 \\
\hline Mojave & 50 & 40.0 & 38.0 & 22.0 & 0.0 \\
\hline Coachella & 19 & 63.2 & 10.5 & 15.8 & 10.5 \\
\hline Colorado River & 20 & 55.0 & 10.0 & 35.0 & 0.0 \\
\hline Indian Wells & 13 & 84.6 & 0.0 & 15.4 & 0.0 \\
\hline \multicolumn{6}{|c|}{ Any inorganic constituents with health-based benchmarks ${ }^{2}$} \\
\hline Desert Region (all study areas) & 206 & 0.0 & 37.2 & 27.4 & 35.4 \\
\hline Owens Valley & 40 & 0.0 & 57.5 & 20.0 & 22.5 \\
\hline Antelope & 61 & 0.0 & 41.0 & 29.5 & 29.5 \\
\hline Mojave & 53 & 0.0 & 35.9 & 35.8 & 28.3 \\
\hline Coachella & 19 & 0.0 & 31.6 & 26.3 & 42.1 \\
\hline Colorado River & 20 & 0.0 & 20.0 & 35.0 & 45.0 \\
\hline Indian Wells & 13 & 0.0 & 15.4 & 23.1 & 61.5 \\
\hline
\end{tabular}

\footnotetext{
${ }^{1}$ Spatially weighted value.

${ }^{2}$ Aquifer-scale proportions for radioactive constituents and for any inorganic constituents with health-based benchmarks were calculated using unadjusted gross alpha activity. The MCL-US applies to adjusted gross alpha radioactivity which is gross alpha activity minus uranium activity.
} 


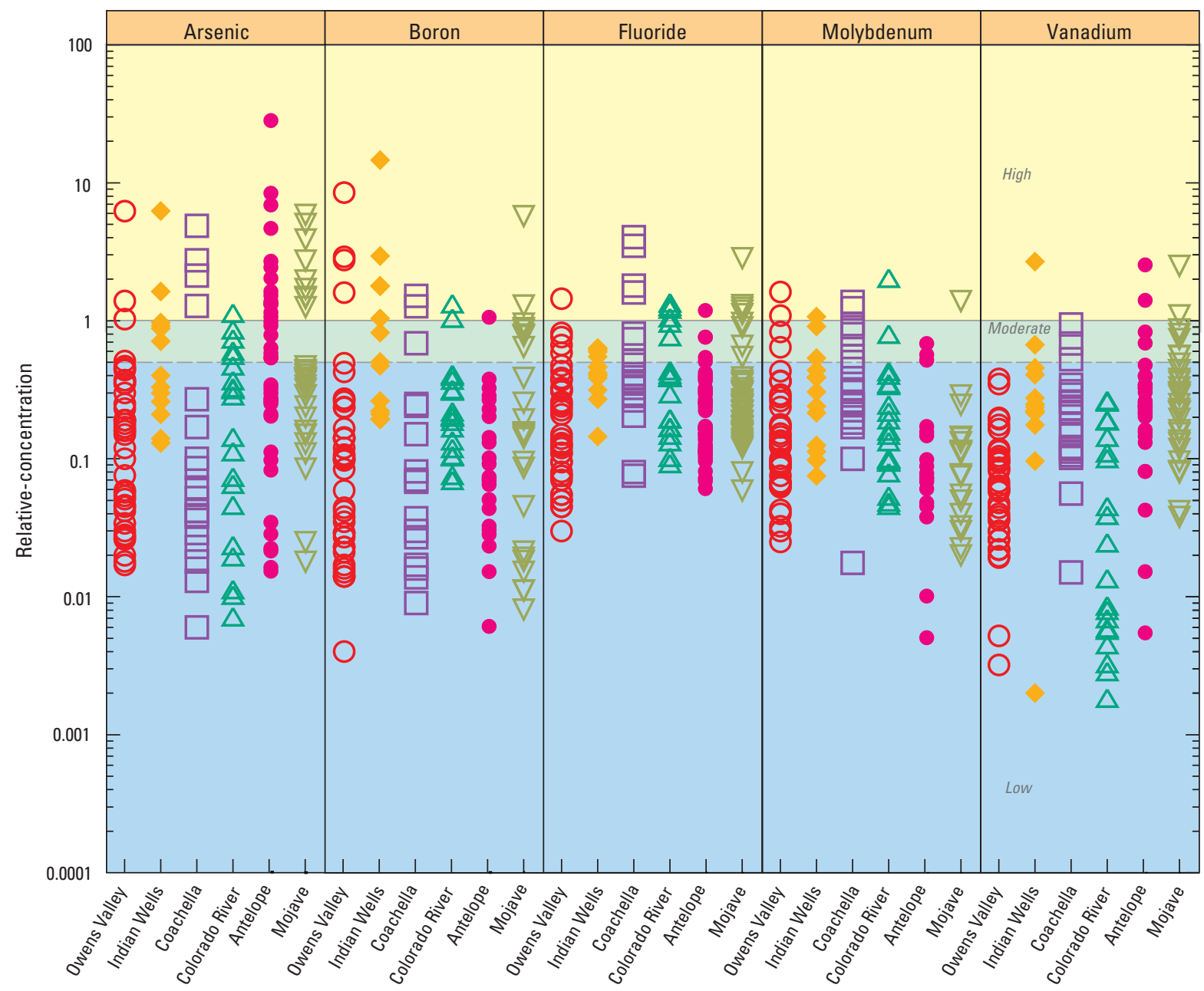

Figure 8. Detected concentrations of arsenic, boron, fluoride, molybdenum, and vanadium in grid wells relative to health-based benchmarks in the California Desert Region Groundwater Ambient Monitoring and Assessment (GAMA) study areas, 2006-2008. 


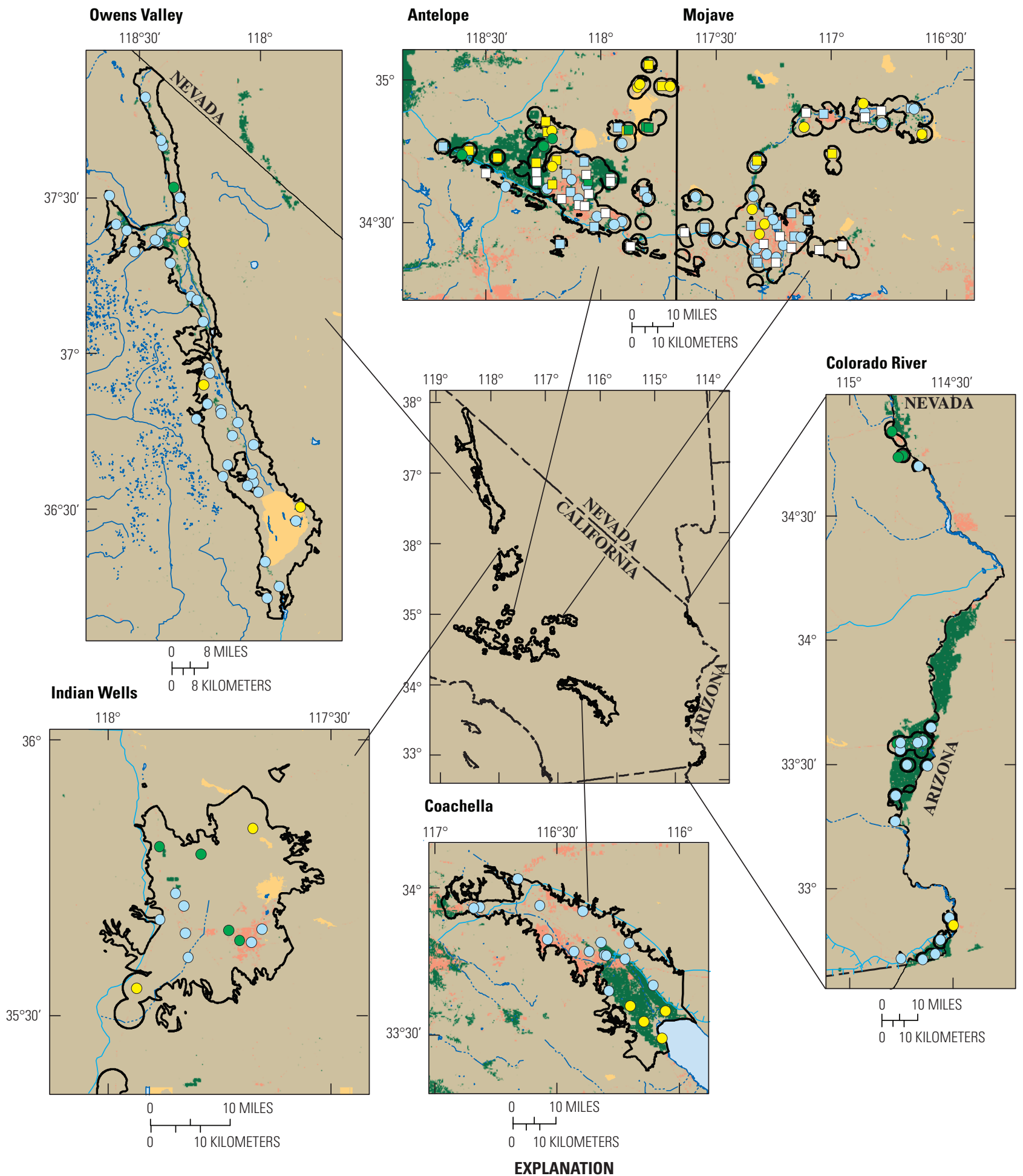

Arsenic, relative-concentration USGS-Grid Data

$\begin{array}{ccc}\bigcirc & \text { Not Detected } & \square \\ \bigcirc & \text { Low } & \square \\ \bigcirc & \text { Moderate } & \square \\ \bigcirc & \text { High } & \square\end{array}$

\section{Aqueduct}

Canal

Stream, perennial

Stream, intermittent

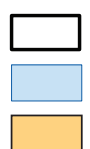

Study area boundary

Lake

Dry lake bed
Urban land use

Agricultural land use

Natural land use

Figure 9. Concentrations of arsenic in grid wells relative to health-based benchmarks in the California Desert Region Groundwater Ambient Monitoring and Assessment (GAMA) study areas, 2006-2008. 


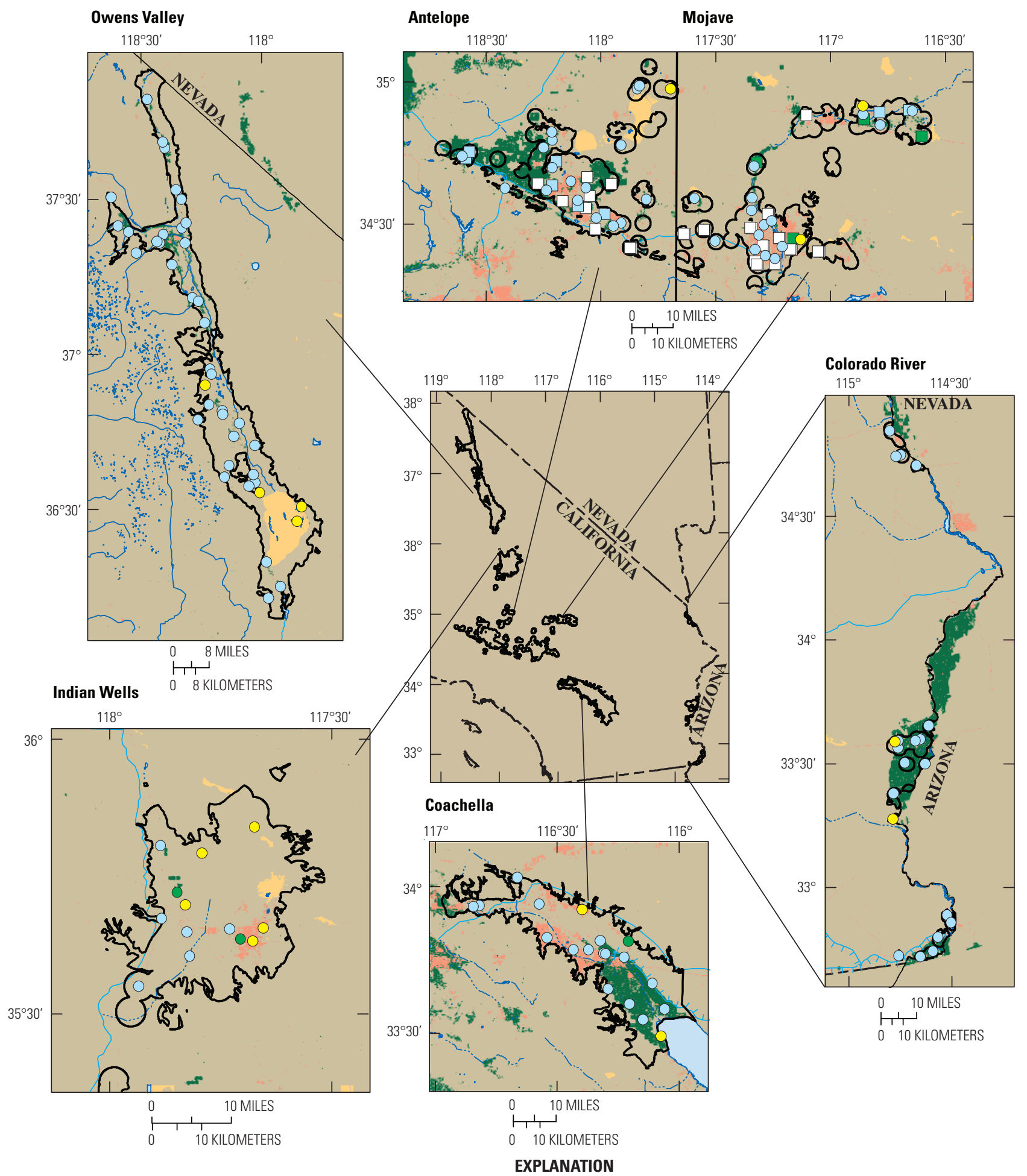

Boron, relative-concentration USGS-Grid Data CDPH-Grid Data

$\begin{array}{ccc}\bigcirc & \text { Not Detected } & \square \\ \bigcirc & \text { Low } & \square \\ \bigcirc & \text { Moderate } & \square \\ \bigcirc & \text { High } & \square\end{array}$

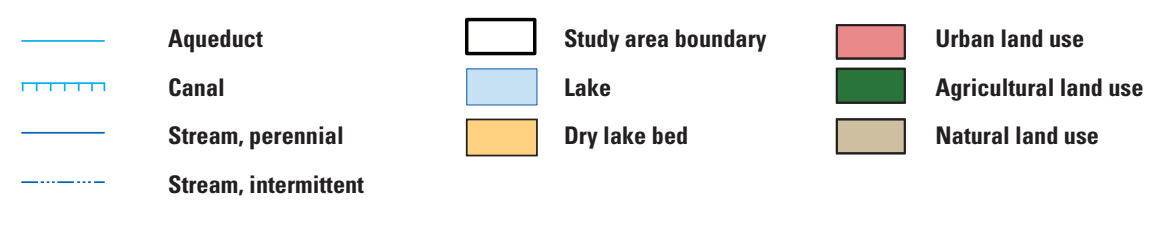

Figure 10. Concentrations of boron in grid wells relative to health-based benchmarks in the California Desert Region Groundwater Ambient Monitoring and Assessment (GAMA) study areas, 2006-2008. 


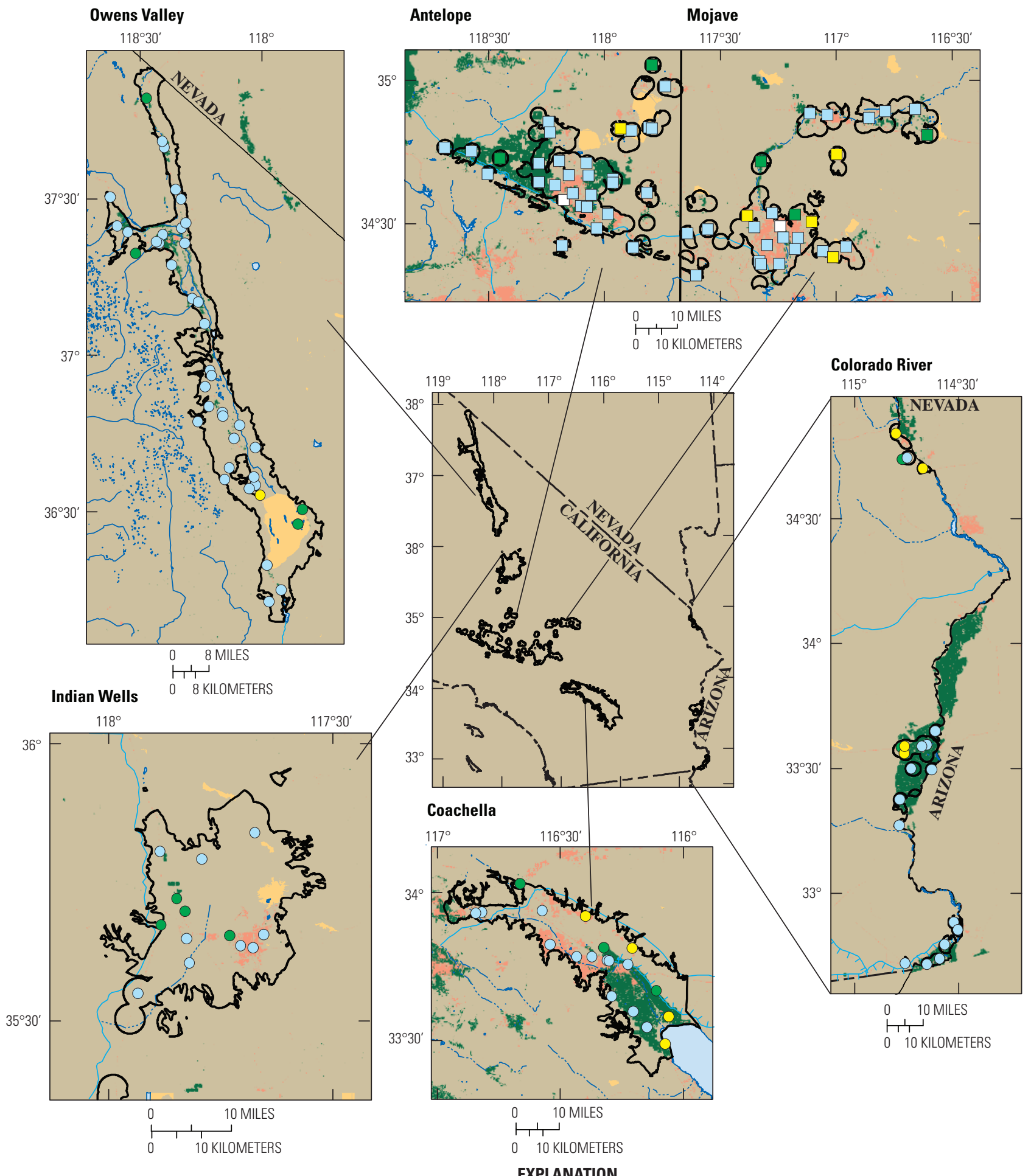

Fluoride, relative-concentration USGS-Grid Dat

\section{CDPH-Grid Data}$$
\text { ○ }
$$

○

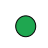

○

$\begin{array}{cr} & \text { CDPH-Grid } \\ \text { Not Detected } & \square \\ \text { Low } & \square \\ \text { Moderate } & \square \\ \text { High } & \square\end{array}$

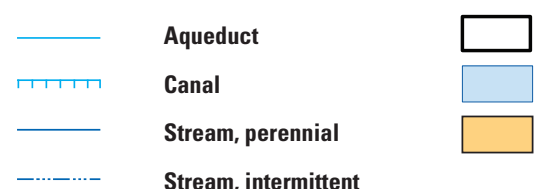

Study area boundary

Lake

Dry lake bed
Urban land use

Agricultural land use

Natural land use

Figure 11. Concentrations of fluoride in grid wells relative to health-based benchmarks in the California Desert Region Groundwater Ambient Monitoring and Assessment (GAMA) study areas, 2006-2008. 


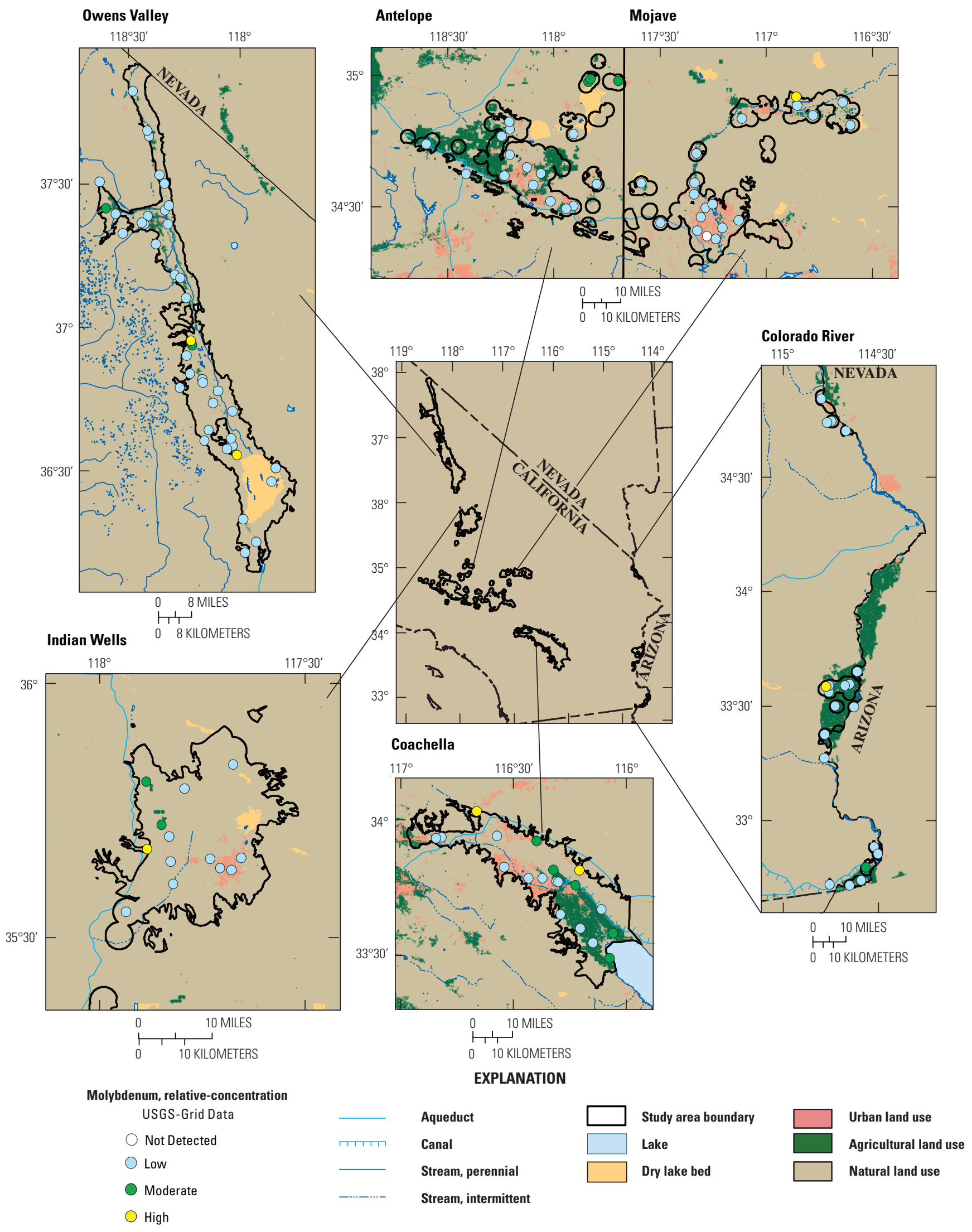

Figure 12. Concentrations of molybdenum in grid wells relative to health-based benchmarks in the California Desert Region Groundwater Ambient Monitoring and Assessment (GAMA) study areas, 2006-2008. 


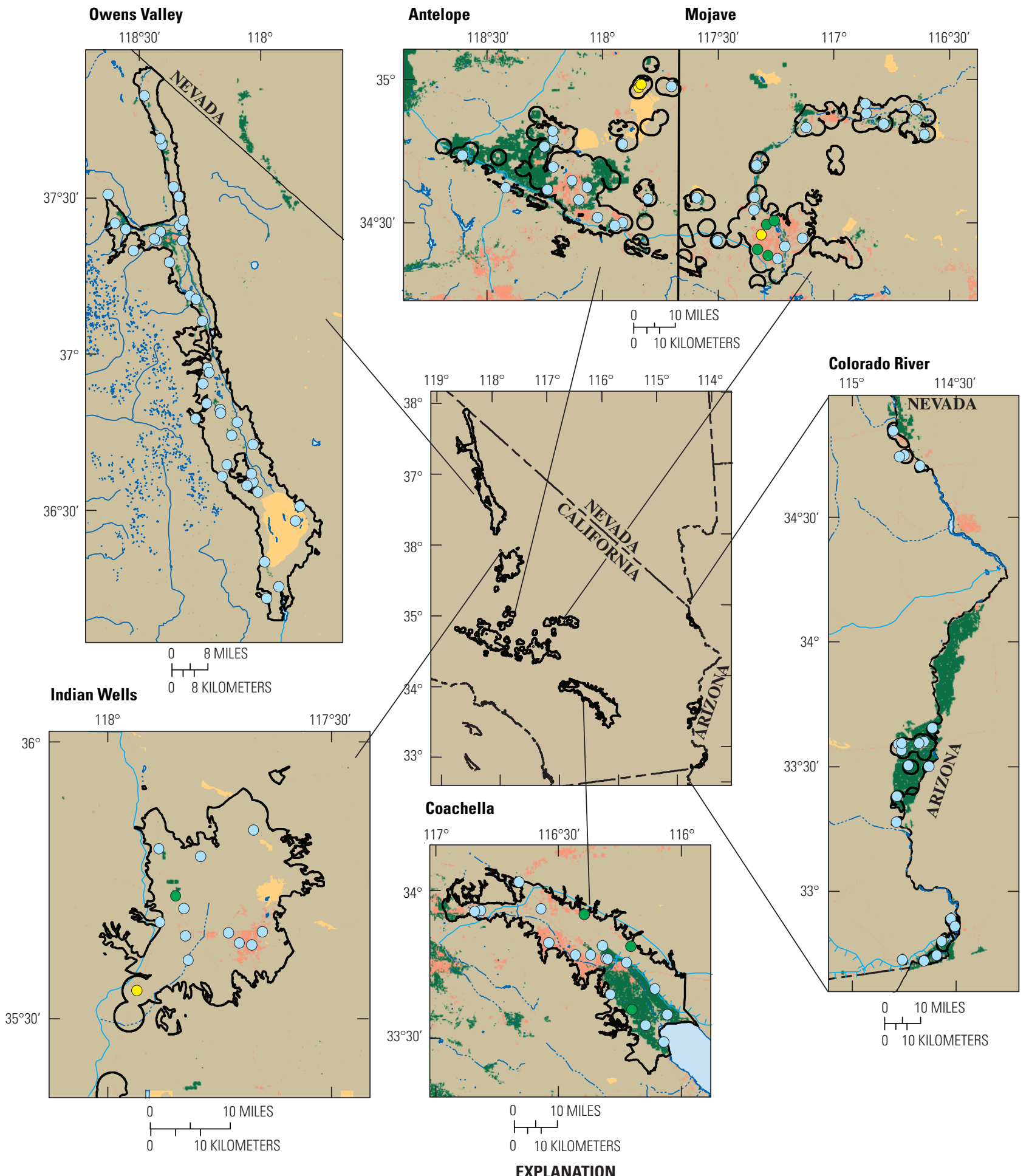

Vanadium, relative-concentration

USGS-Grid Data CDPH-Grid Data

$\begin{array}{ccccl}\bigcirc & \text { Low } & \square & \text { Canal } \\ \bigcirc & \text { Moderate } & \square & - & \text { Stream, perennial } \\ 0 & \text { High } & \square & -\cdots-\cdots- & \text { Stream, intermittent }\end{array}$

Figure 13. Concentrations of vanadium in grid wells relative to health-based benchmarks in the California Desert Groundwater Ambient Monitoring and Assessment (GAMA) study areas, 2006-2008. 


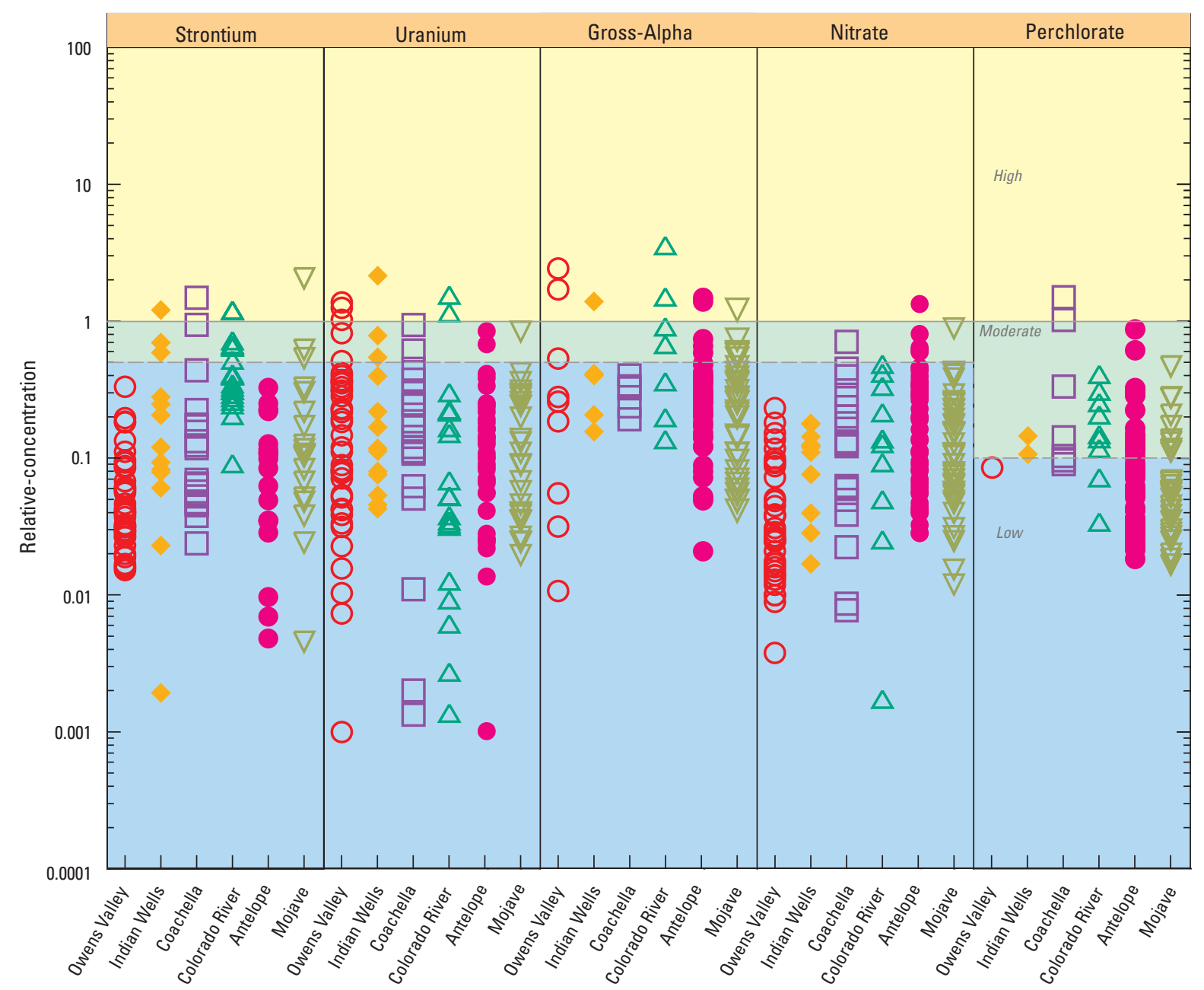

Figure 14. Concentrations of strontium, uranium, gross-alpha radioactivity, nitrate, and perchlorate in grid wells relative to health-based benchmarks in the California Desert Groundwater Ambient Monitoring and Assessment (GAMA) study areas, 2006-2008. 


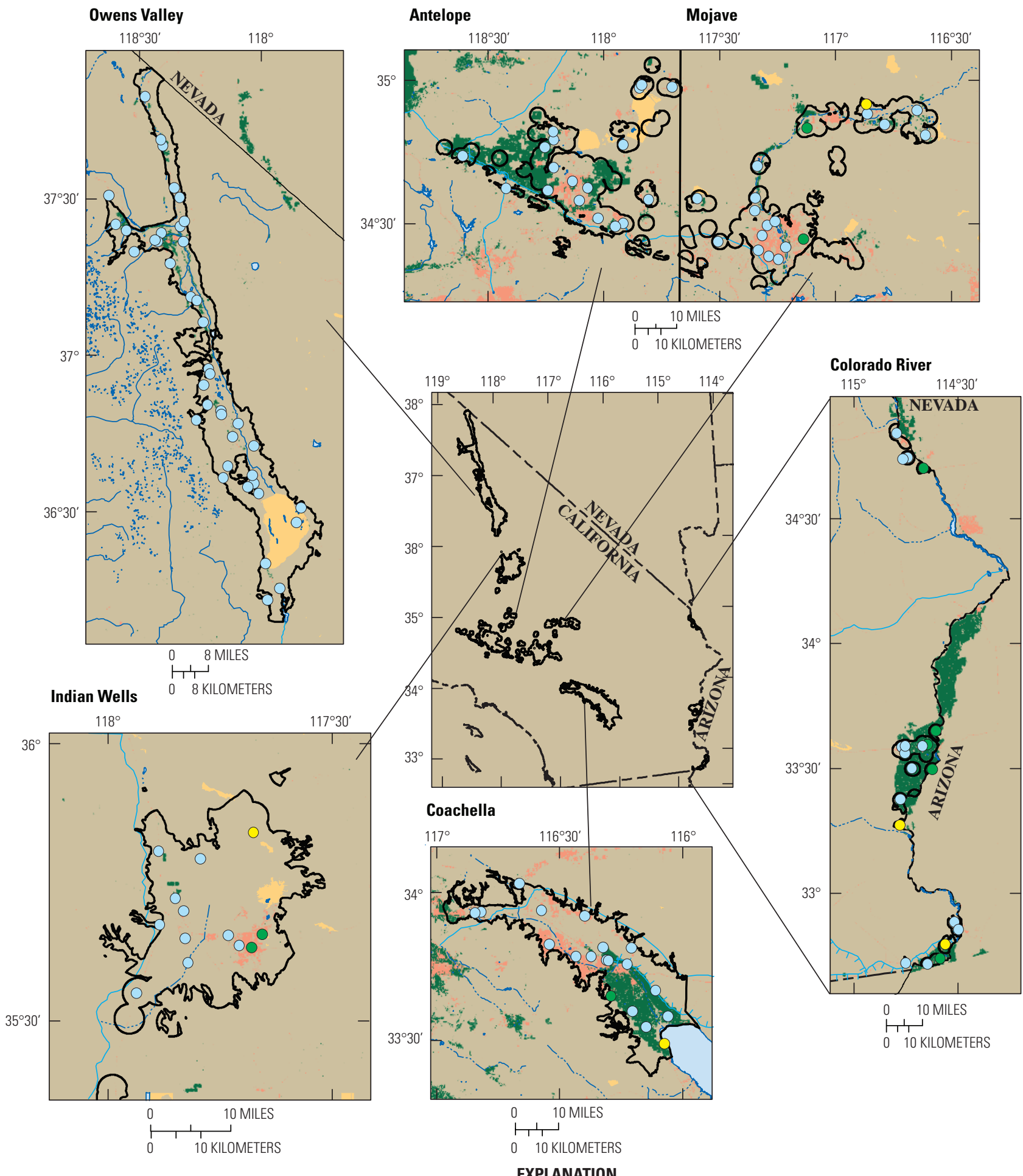

Strontium, relative-concentration

USGS-Grid Data CDPH-Grid Data

\begin{tabular}{cccll} 
& Low & $\square$ & & Aqueduct \\
& Moderate & $\square$ & - & Canal \\
& - & & Stream, perennial \\
\hline & High & $\square$ & $-\cdots-\cdots-$ & Stream, intermittent
\end{tabular}

Study area boundary

Lake

Dry lake bed
Urban land use

Agricultural land use

Natural land use

Figure 15. Concentrations of strontium in grid wells relative to health-based benchmarks in the California Desert Region Groundwater Ambient Monitoring and Assessment (GAMA) study areas, 2006-2008. 


\section{Radioactive Constituents}

Radioactive constituents had high RCs for one or more constituents in 7.1 percent of the Desert Region's primary aquifers, moderate RCs in 11.1 percent, and low RCs in 81.9 percent (table 6). The high RCs reflect detections of gross-alpha radioactivity and uranium (table 5). Radon-222 was detected at moderate concentrations in OV and COL, and at low RCs in COA, ANT, and MOJ; no data were available for IW. The other radioactive constituents were found only at low RCs in the primary aquifers in the Desert Region.

Gross-alpha radioactivity was found at high RCs in 6.6 percent of the Desert Region's primary aquifers and at moderate RCs in 5.4 percent (table 5). It was found at high RCs in all Desert Region study areas, except COA, where it was only found at low RCs (tables B3A-F). The highest $\mathrm{RC}$ was found in COL (fig. 14). The distributions of high RCs varied among the study areas. In OV, high RCs were in upgradient and downgradient wells; in ANT and MOJ, in downgradient wells; in IW, only in an upgradient well; and in COL, in the Palo Verde basin (fig. 16). These RCs were calculated using unadjusted gross-alpha radioactivity; the MCL-US applies to adjusted gross-alpha radioactivity, which is equal to the measured gross-alpha activity minus uranium activity (U.S. Environmental Protection Agency, 2000).

Uranium was detected at high RCs in 3.2 percent and moderate RCs in 6.9 percent of the Desert Region's primary aquifers (table 5); it was detected at high RCs in OV, IW, and COL, and at moderate RCs in ANT, COA, and MOJ (fig. 14; tables B3A-F). The highest RC was in IW (fig. 14). The distribution of high RCs varied in the study areas. In OV, high RCs of uranium were in the upgradient areas (fig. 17). In ANT and MOJ, the moderate uranium RCs were in the downgradient wells. In IW and COA, high RCs were in upgradient and downgradient areas; in COL, high RCs were only in the Palo Verde basin.

\section{Nutrients}

Nutrient constituents had high RCs in 0.8 percent of the Desert Region's primary aquifers and moderate RCs in 3.4 percent (table 6), reflecting the detections of nitrate (table 5). Ammonia and nitrite were detected only at low concentrations or were below reporting levels. Note that the high RC calculated for the Desert Region ( 0.8 percent) includes high nitrate values that were in wells used to calculate the spatially weighted aquifer proportion in COA (table 6).

Nitrate was detected at high RCs in grid wells in ANT, at moderate RCs in MOJ and COA, and at low RCs or not detected in OV, IW, and COL (fig. 14; tables B3A-F). The highest RC was in ANT (ig. 14).

\section{Special-Interest Constituent: Perchlorate}

Perchlorate was detected at high RCs in 2.4 percent of the primary aquifers in the Desert Region, moderate in 17.2 percent, and low in 22.1 percent; it was not detected in
58.3 percent of the primary aquifers (tables 5 and $\underline{6}$ ). The high RCs occurred in COA, in two grid wells on the southwestern side of the study area (fig. 18). Moderate RCs were detected in grid wells in IW, ANT, MOJ, and COL (fig. 14). Perchlorate was detected at low RCs in one grid well in OV. Moderate or high RCs occurred in all parts of the groundwater flow systems in COA, ANT, MOJ, and COL; moderate RCs were detected on the west side of IW (ig. 18).

\section{Inorganic Constituents with Non- Health-Based Benchmarks}

The inorganic constituents that have non-health-based benchmarks (SMCLs), as a class, had high RCs for one or more constituents in $\mathbf{1 8 . 6}$ percent of the primary aquifers in the Desert Region, moderate RCs in 16.0 percent, and low RCs in 65.4 percent (table 6). High RCs of three or more of these constituents were detected in all of the Desert Region study areas (appendix B, tables B3A-F). High RCs for this class of constituents reflected high RCs for TDS, manganese, sulfate, iron, and chloride (table 5 ).

Total dissolved solids were detected at high RCs in 11.3 percent of the Desert Region's primary aquifers and at moderate RCs in 18.0 percent (table 5). TDS was detected at high RCs in all of the Desert Region study areas (fig. 19; tables B3A-F). The highest RC was in COA (fig. 19). The high RCs of TDS were in the downgradient areas of the groundwater flow systems all six study areas (fig. 20).

Manganese was detected at high RC in 9.3 percent of the Desert Region's primary aquifers and at moderate RCs in 2.1 percent (table 5). High RCs occurred in all study areas (fig. 19). The highest RC was detected in COL. High RCs of manganese were in the downgradient areas of OV, IW, COA, and ANT (fig. 21). A high RC was detected in the upgradient area of MOJ. High RCs were in the Palo Verde and Yuma basins in COL.

Sulfate was detected at high RCs in 4.4 percent of the Desert Region's primary aquifers and at moderate RCs in 12.4 percent (table 5). High RCs occurred in MOJ, COA, and COL, moderate RCs occurred in ANT and IW, and low RCs occurred in OV. The highest RC was in MOJ (fig. 19). High and moderate RCs were generally in the downgradient areas within each of the study areas except OV (fig. 22).

Iron was detected at high RCs in 4.4 percent of the Desert Region's primary aquifers and at moderate RCs in 5.2 percent (table 5). High RCs were in OV, COL, ANT, and MOJ; iron was low or not detected in IW and COA (figs. 19 and 23). The highest RC was in OV (ig. 19).

Chloride was detected at high RCs in 2.9 percent of the Desert Region's primary aquifers and at moderate RCs in 3.8 percent (table 5). High RCs occurred in IW, COA, COL, and MOJ; moderate RCs occurred in ANT, and low RCs occurred in OV (figs. 19 and 24). The highest RC was in IW (fig. 19). 


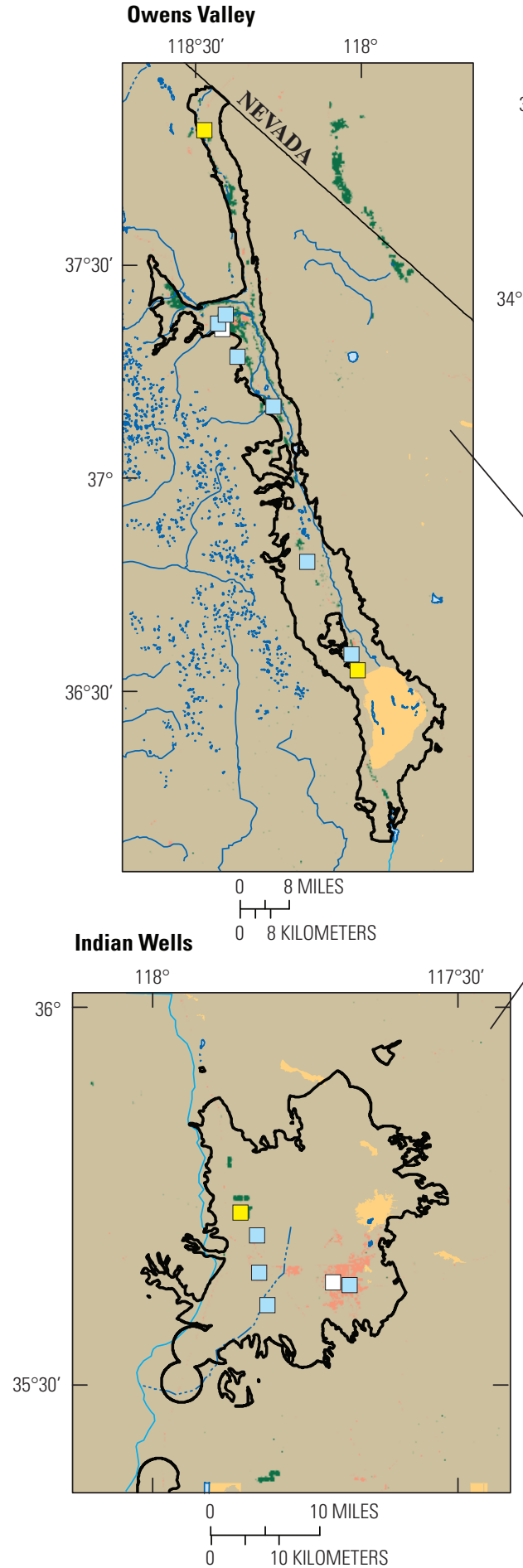

Gross alpha radioactivity, relative concentrationGross alpha radioactivities were not adjusted for uranium activity. The MCL-US applies to adjusted gross alpha radioactivity which is gross alpha minus uranium activity.

USGS Grid-Data

0

Not Detected

CDPH Grid-Data

Low

Moderate

High
Antelope

Mojave

$117^{\circ} 30^{\prime} \quad 117^{\circ} \quad 116^{\circ} 30^{\prime}$

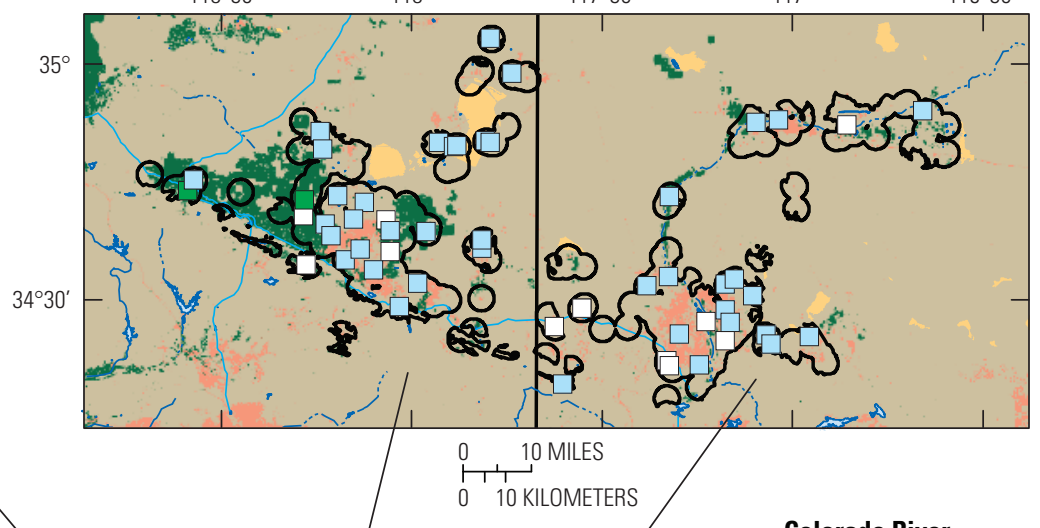

Colorado River
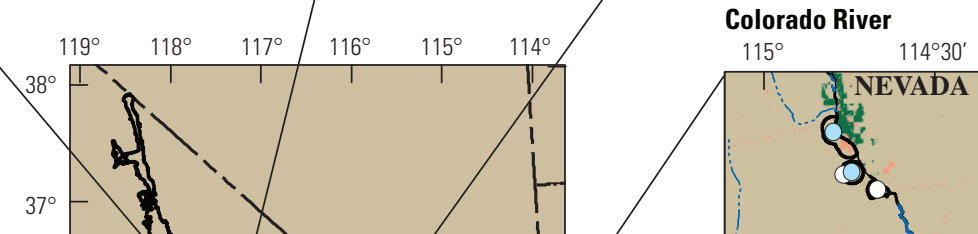

38
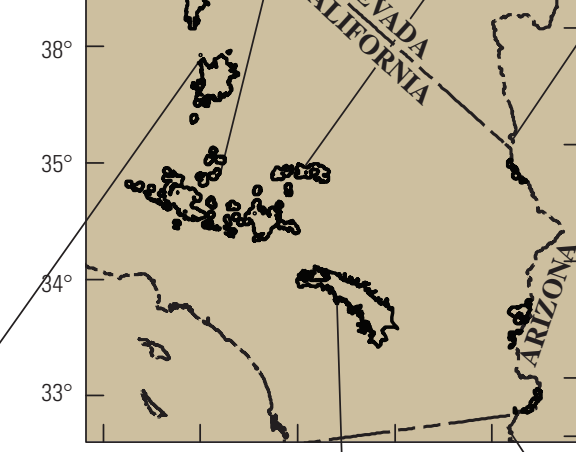

Coachella

EXPLANATION

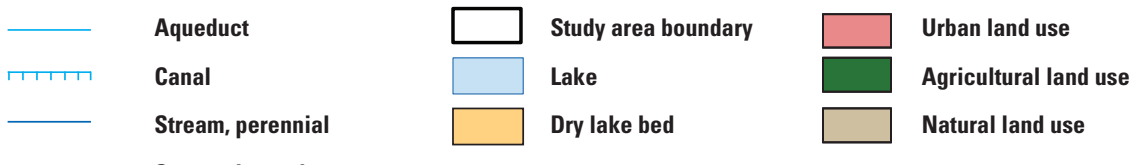

Stream, intermittent

Figure 16. Concentrations of gross-alpha radioactivity in grid wells relative to health-based benchmarks in the California Desert Region Groundwater Ambient Monitoring and Assessment (GAMA) study areas, 2006-2008. 


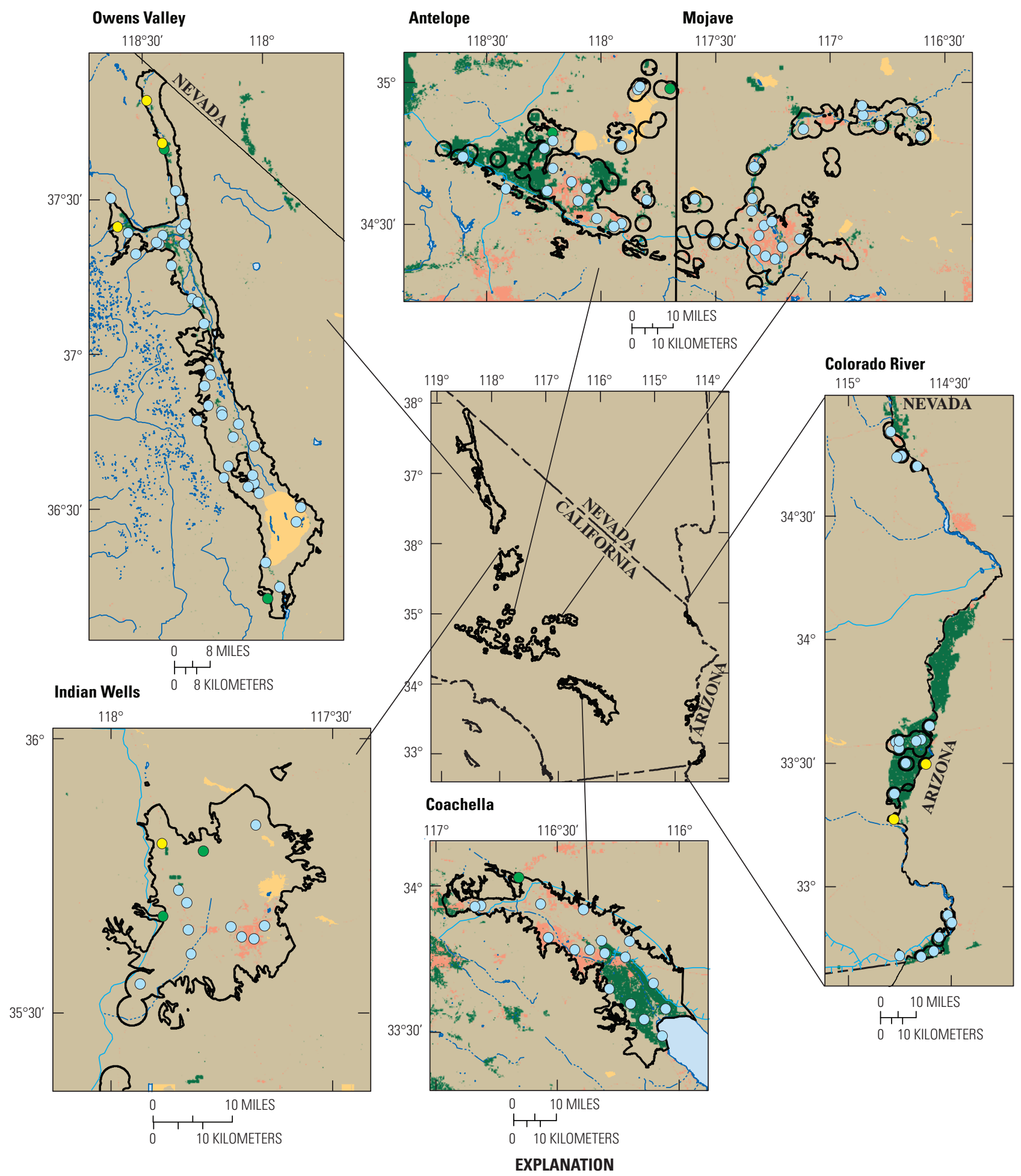

Uranium, relative-concentration

USGS-Grid Data CDPH-Grid Data

\begin{tabular}{ccccl}
$\bigcirc$ & Low & $\square$ & Canal \\
$\bigcirc$ & Moderate & $\square$ & - & Stream, perennial \\
\hline & High & $\square$ & $-\cdots-\cdots-$ & Stream, intermittent
\end{tabular}

Study area boundary

Lake

Dry lake bed
Urban land use Agricultural land use

Natural land use

Figure 17. Concentrations of uranium in grid wells relative to health-based benchmarks in the California Desert Region Groundwater Ambient Monitoring and Assessment (GAMA) study areas, 2006-2008. 


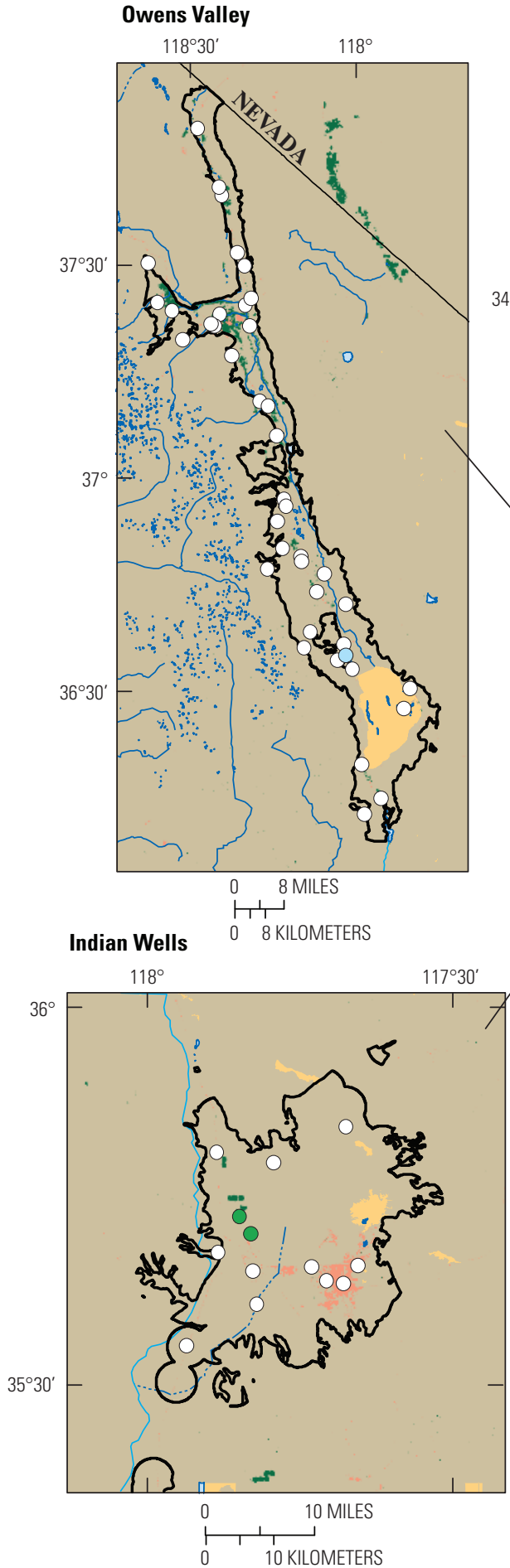

Perchlorate, relative-concentration USGS-Grid Data

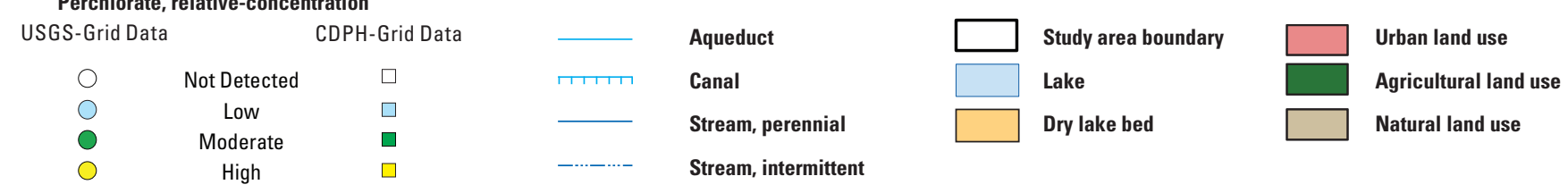

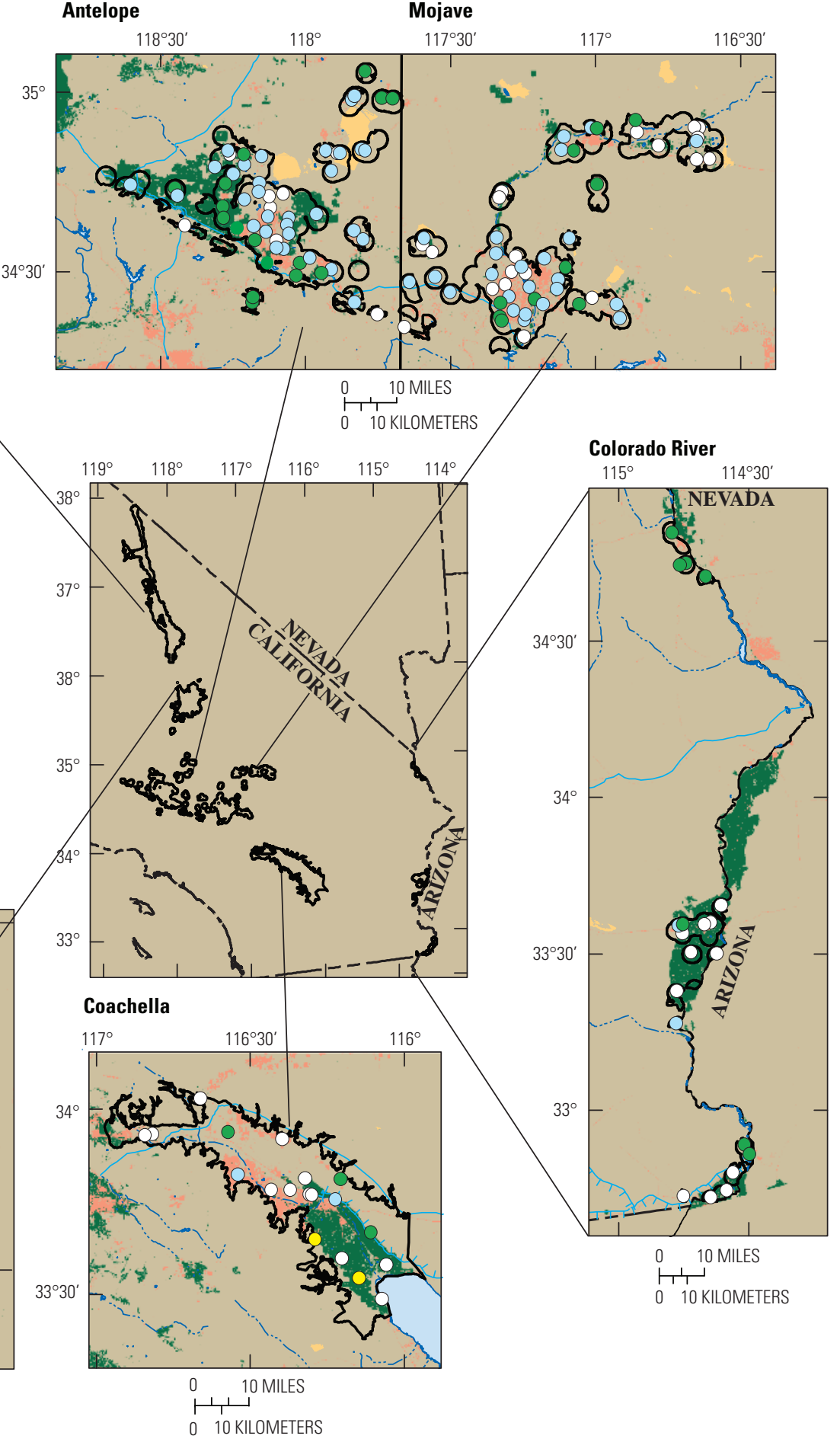

EXPLANATION

Figure 18. Concentrations of perchlorate in grid wells relative to health-based benchmarks in the California Desert Region Groundwater Ambient Monitoring and Assessment (GAMA) study areas, 2006-2008. 


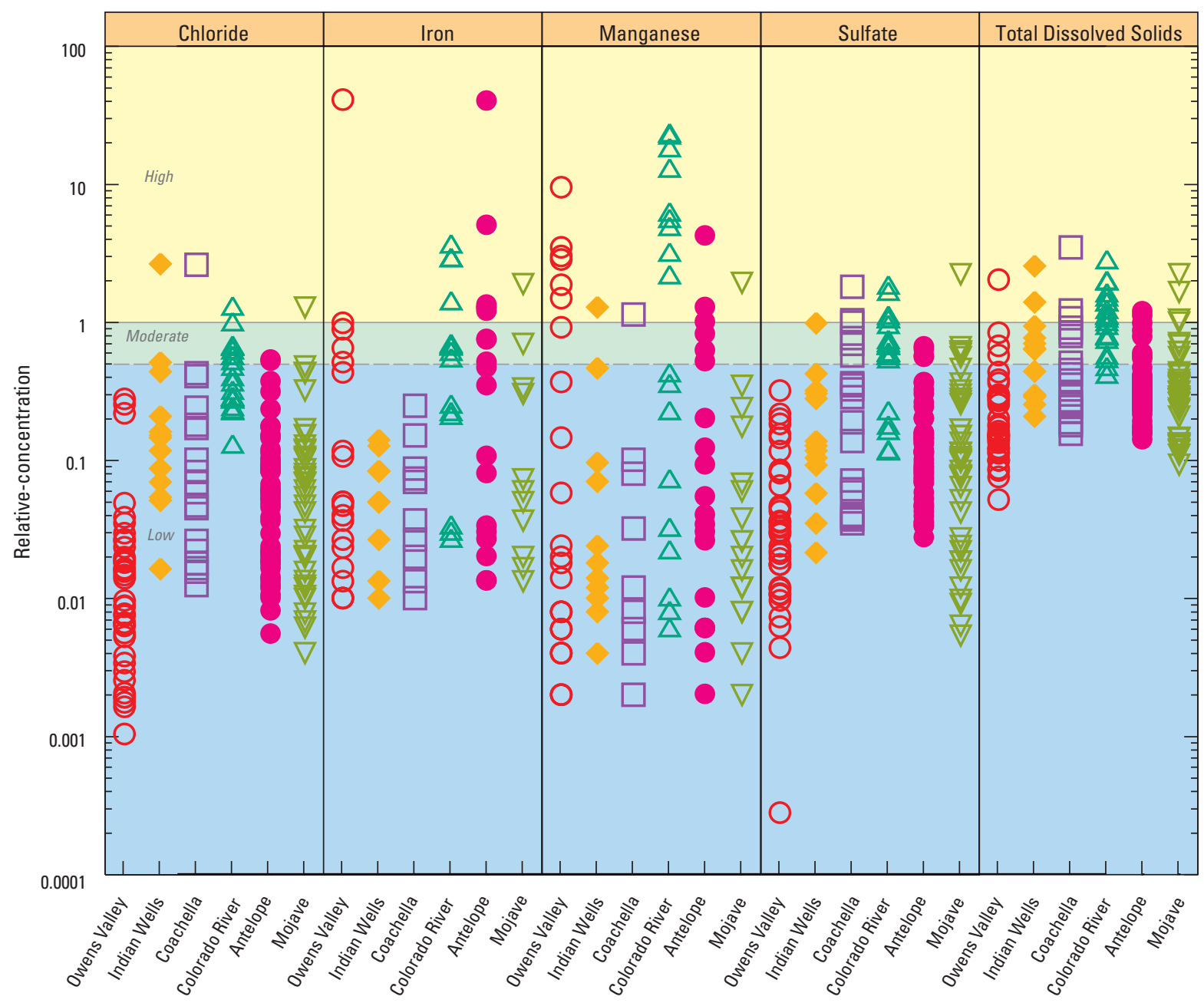

Figure 19. Concentrations of chloride, iron, manganese, sulfate, and total dissolved solids in grid wells relative to non-health-based benchmarks in the California Desert Groundwater Ambient Monitoring and Assessment (GAMA) study areas, 2006-2008. 


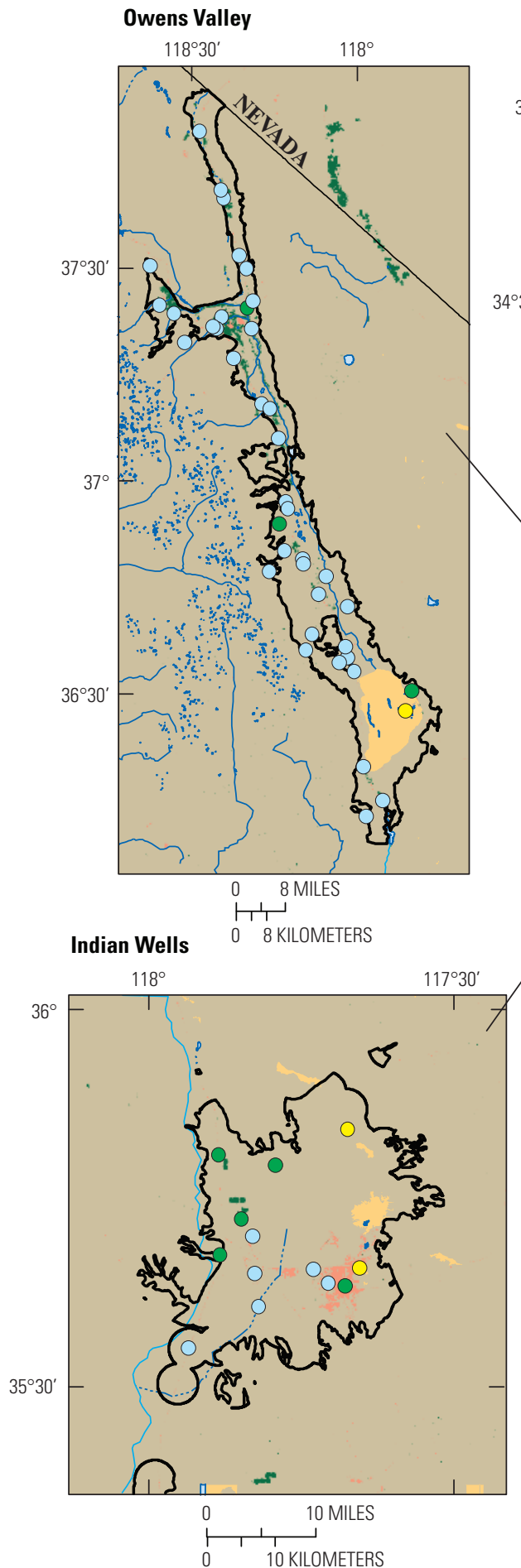

Total dissolved solids, relative-concentration USGS-Grid Data

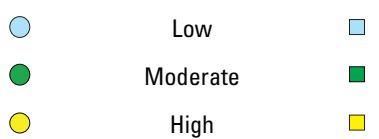

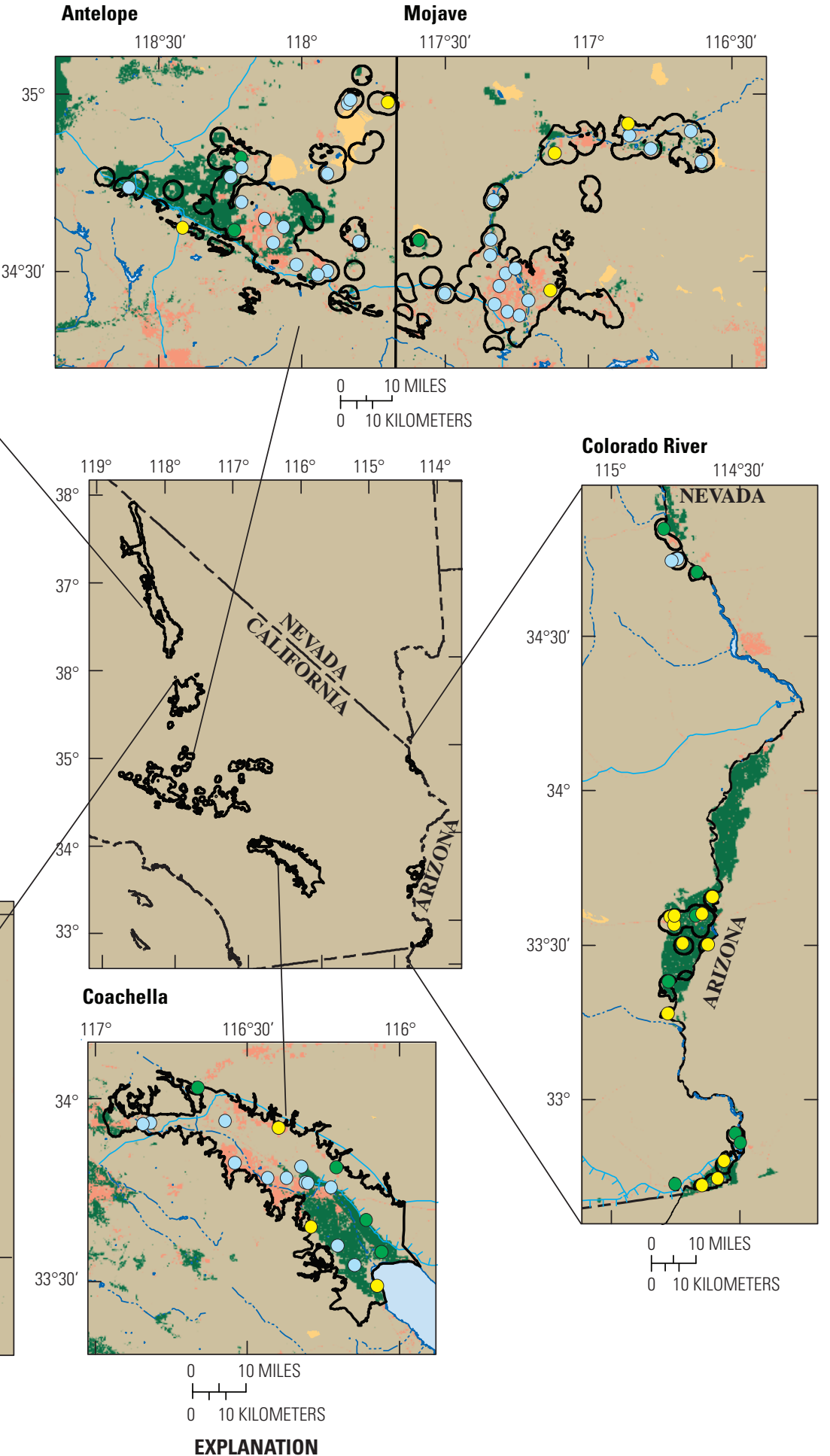

EXPLANATION

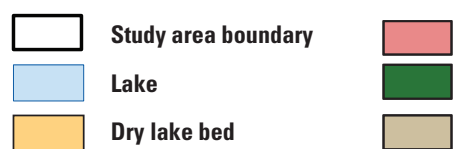

Dry lake bed
Urban land use

Agricultural land use

Natural land use

Figure 20. Concentrations of total dissolved solids in grid wells relative to non-health-based benchmarks in the California Desert Region Groundwater Ambient Monitoring and Assessment (GAMA) study areas, 2006-2008. 


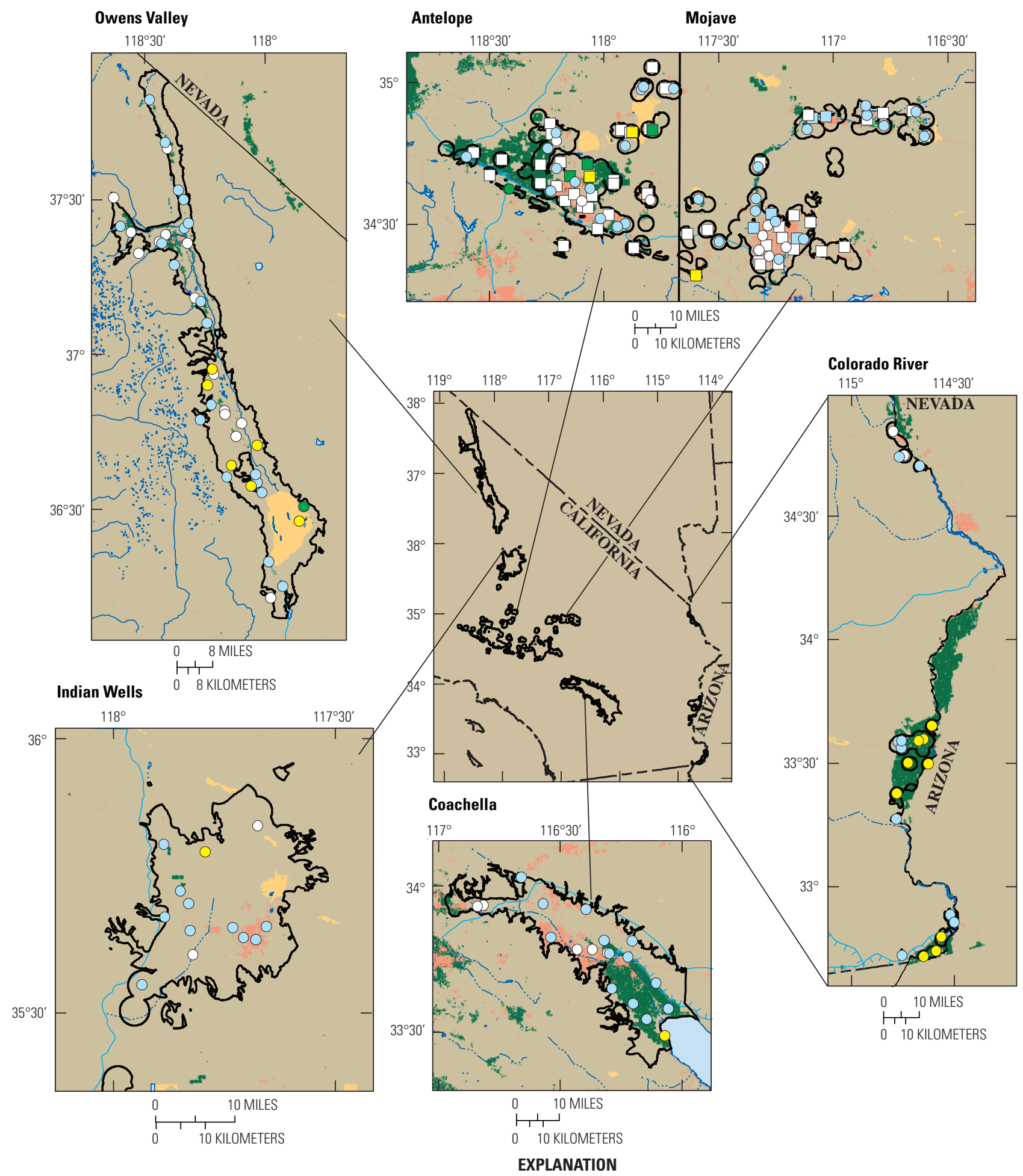

Manganese, relative-concentration

USGS-Grid Data CDPH-Grid Data

$\begin{array}{ccc}\bigcirc & \text { Not Detected } & \square \\ \bigcirc & \text { Low } & \square \\ \bigcirc & \text { Moderate } & \square \\ \bigcirc & \text { High } & \square\end{array}$

Aqueduct

Canal

Stream, perennial

Stream, intermittent

Figure 21. Concentrations of manganese in grid wells relative to non-health-based benchmarks in the California Desert Region Groundwater Ambient Monitoring and Assessment (GAMA) study areas, 2006-2008. 


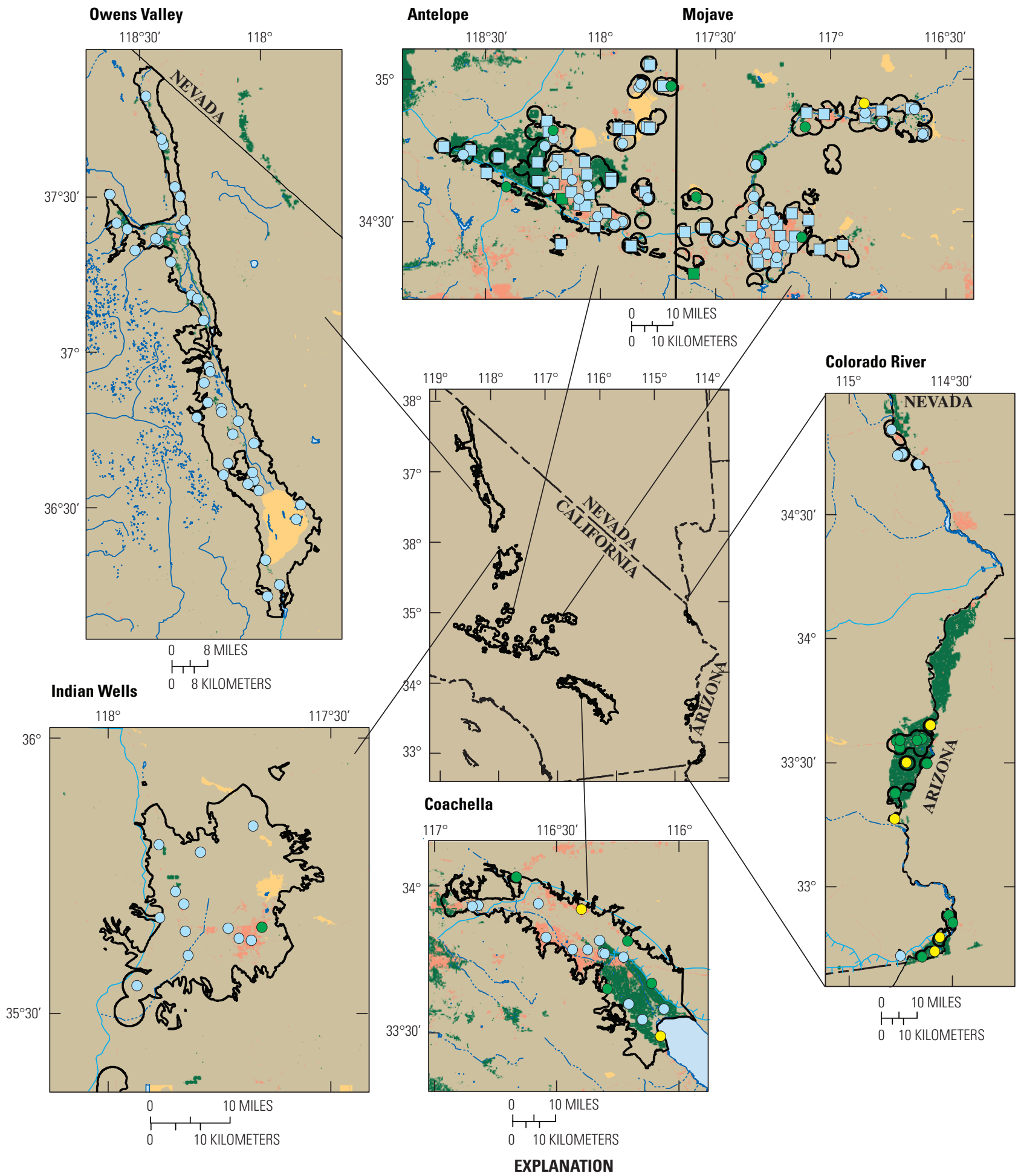

Sulfate, relative-concentration USGS-Grid Dat CDPH-Grid Data

$\begin{array}{ccccl}\bigcirc & \text { Low } & \square & \square+11 & \text { Canal } \\ \bigcirc & \text { Moderate } & \square & - & \text { Stream, perennial } \\ 0 & \text { High } & \square & -\ldots-\ldots- & \text { Stream, intermittent }\end{array}$

Figure 22. Concentrations of sulfate in grid wells relative to non-health-based benchmarks in the California Desert Region Groundwater Ambient Monitoring and Assessment (GAMA) study areas, 2006-2008. 


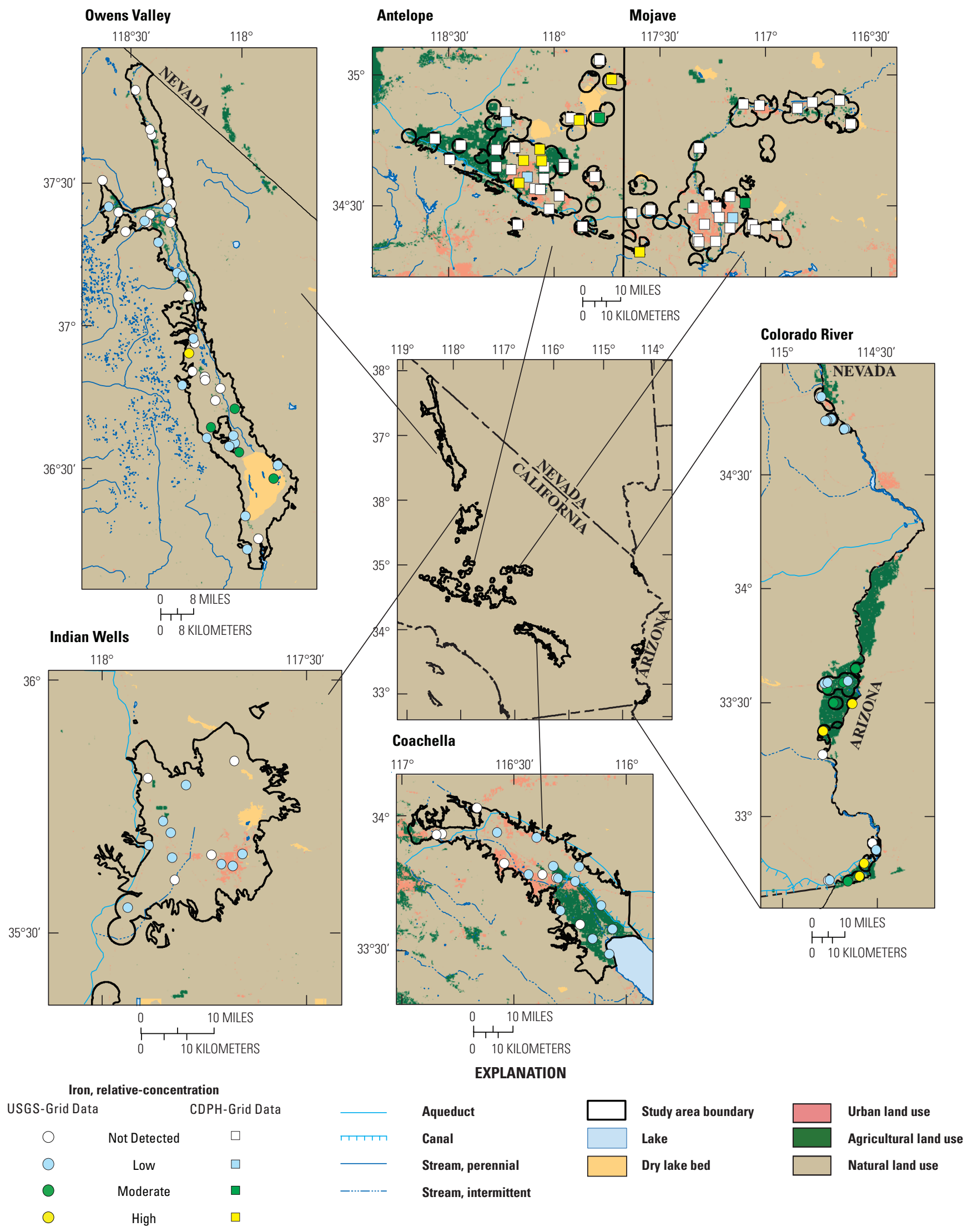

Figure 23. Concentrations of iron in grid wells relative to non-health-based benchmarks in the California Desert Region Groundwater Ambient Monitoring and Assessment (GAMA) study areas, 2006-2008. 


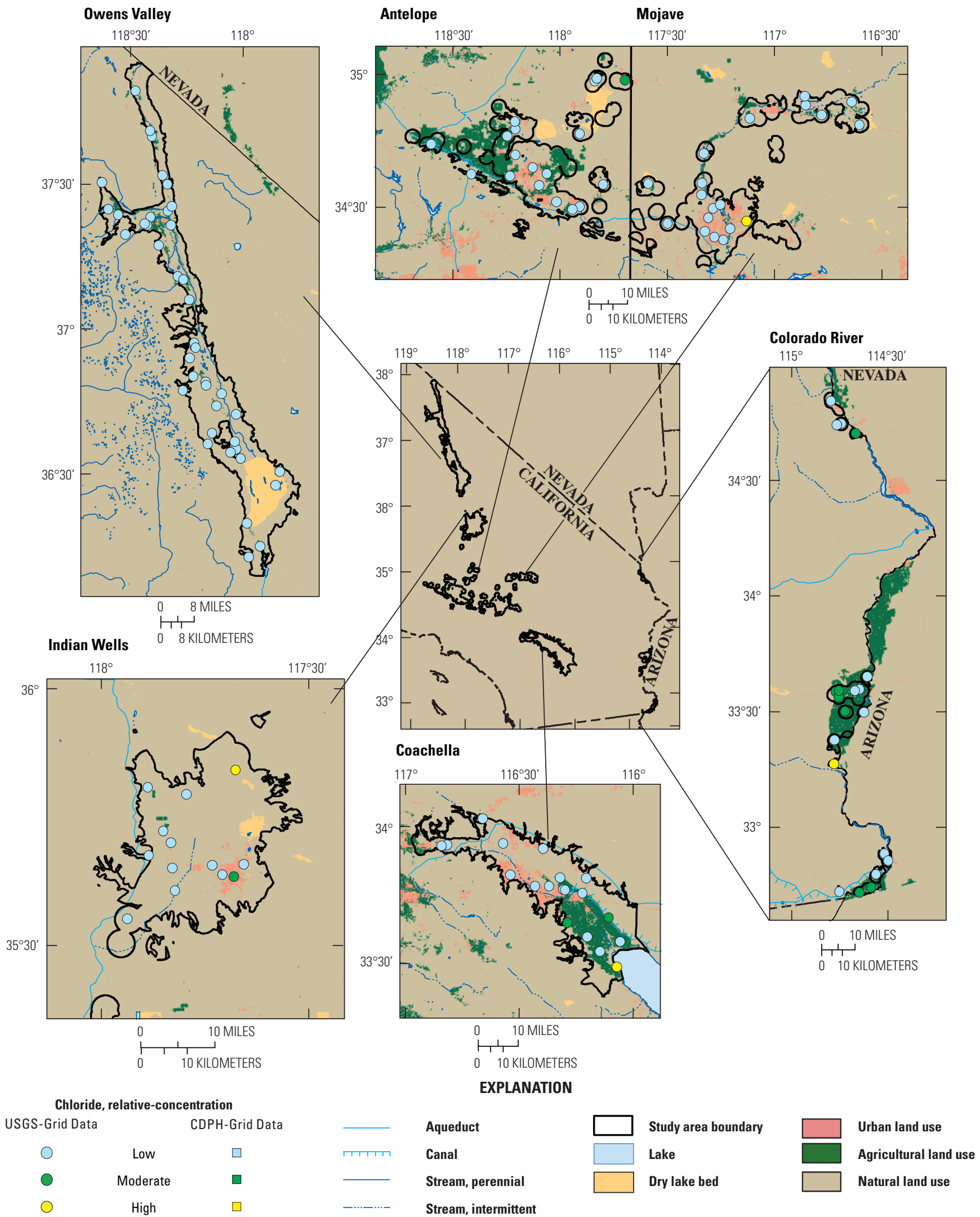

Figure 24. Concentrations of chloride in grid wells relative to non-health-based benchmarks in the California Desert Region Groundwater Ambient Monitoring and Assessment (GAMA) study areas, 2006-2008. 


\section{Organic Constituents}

Data for 149 organic compounds were used in this report, including 83 volatile organic compounds (VOCs), 64 pesticides and pesticide degradates, and 2 special-interest constituents (NDMA and 1,2,3-trichloropropane) (tables 4 and B2A-C). Of these, 42 were detected in at least one grid well in the Desert Region's primary aquifers. Of the 200 grid wells sampled in the Desert Region, 49.7 percent had no detections of any organic constituents, and 48.0 percent of the primary aquifer systems had RCs that were considered low $(\leq 0.1$ of benchmarks) (table 7).

Among all organic constituents with health-based benchmarks (78 constituents), the proportion of the Desert Region's primary aquifers with high concentrations was 0.3 percent (table 7), which reflects one detection of NDMA (table 7) in the Mojave study unit. This was the only detection of an organic constituent at a concentration greater than a health-based benchmark.

The proportion of the Desert primary aquifers having moderate RCs of organic constituents was 2.0 percent (table 7). Five VOCs were detected at moderate concentrations in grid wells: carbon tetrachloride (tetrachloromethane), chloroform (trichloromethane), 1,2-dichloropropane, tetrachoroethylene (PCE), and 1,2-dichloroethane (table 5). One pesticide constituent, dieldrin, was detected at a moderate RC. Of these six constituents detected at moderate RCs, only chloroform was detected (at low and moderate RCs) in more than 10 percent of the grid wells in the Desert Region (fig. 25).

Twenty-five organic constituents having health-based benchmarks were detected at only low RCs (ig. 25). Of these, only one pesticide, simazine, was detected in more than 10.0 percent of the grid wells in the Desert Region. The proportion of the Desert Region's primary aquifers having low RCs of organic constituents was 48.0 percent. The proportion of the Desert Region's primary aquifers having no detections of organic constituents with health-based benchmarks was 49.7 percent (table 7).

Nine organic constituents that have no health-based benchmarks were detected in grid wells in the Desert Region. Of these, desethylatrazine, a degradation product of the herbicide atrazine and other triazine pesticides, was detected in more than 10 percent of the 200 grid wells (fig. 25).

\section{Volatile Organic Compounds}

Of the 83 VOCs analyzed, 27 were detected in at least one grid well in the Desert Region (table 4 and table B2A). The detection frequency for VOCs in the 200 grid wells was 32.5 percent. Four VOCs were detected that do not have health-based benchmarks: tetrahydrofuran (detected in two grid wells), chloroethane (detected in one grid well), chloromethane (detected in one grid well), and dibromomethane (detected in one grid well).
In grid wells in the Desert Region, 23 VOCs were detected that have health-based benchmarks. Of these, 18 were detected only at low RCs. None of these were detected in more than 10 percent of the grid wells. Five VOCs were detected in grid wells at moderate RCs: carbon tetrachloride, chloroform, 1,2-dichloroethane, 1,2-dichloropropane, and tetrachloroethene. Of these, only chloroform was detected in more than 10 percent of the grid wells. No VOCs were detected above a health-based benchmark (figs. 25 and $\underline{26}$ ).

Chloroform was detected at moderate RCs in 0.4 percent of the Desert Region's primary aquifers (table 5), at low concentrations in 20.2 percent, and not detected in 79.4 percent. It was detected in all six study areas, with the highest RC in ANT (fig. 26). Chloroform was detected in 23 percent of 200 grid wells in the Desert Region study areas. The one moderate RC was in a downgradient grid well in ANT; low RCs were distributed throughout most study areas (fig. 27). No chloroform was detected in grid wells in the Yuma subbasin in COL.

\section{Pesticides and Pesticide Degradates}

Of the 64 pesticides and pesticide degradates analyzed in all study areas, 14 were detected; 7 were parent compounds with benchmarks, 3 were parent compounds without benchmarks, and 4 were degradates without benchmarks (table B2B). Pesticides or pesticide degradates were detected in 17.1 percent of the Desert Region's primary aquifers at low RCs and in 0.3 percent (one grid well) at moderate RCs (table 7). The moderate RC was found in MOJ. All detected concentrations of pesticides were below health-based benchmarks (fig. 28). The individual constituents that were not detected and the wells sampled in the Desert Region are listed in Densmore and others (2009), Goldrath and others (2009, 2010), Mathany and Belitz (2009), and Schmitt and others (2009).

Dieldrin, an insecticide, was detected at a moderate RC in 0.3 percent of the Desert Region's primary aquifers. The detection was in one well in MOJ (figs. 28 and 29; table 5). This was the only detection of dieldrin.

Simazine, an herbicide, was detected at low RCs in 13.9 percent of the grid wells and was not detected in the remaining 86.1 percent of the grid wells, resulting in 100 percent of the wells being in the "low" category for the Desert Region's primary aquifers (ig. 28). It was detected in one or more wells within every study area except IW (fig. 29).

A trazine was detected at low RCs in 9.8 percent of the grid wells and was not detected in the remaining 90.2 percent of the grid wells (fig. 25). Atrazine was detected in one or more of the wells in all study areas except IW (ig. 28). Desethylatrazine, a degradate of atrazine and other triazine pesticides, was detected in 12.3 percent of the grid wells (fig. 25). The combined detection frequency of atrazine and desethylatrazine in grid wells was 13.9 percent. 
Table 7. Summary of grid-based aquifer-scale proportions for organic constituent classes in the California Desert Groundwater Ambient Monitoring and Assessment (GAMA) study areas.

[Low, relative-concentration less than 0.1; Moderate, relative-concentration between 0.1 and 1; High, relative-concentration greater than 1.0; Values are gridbased except where footnoted]

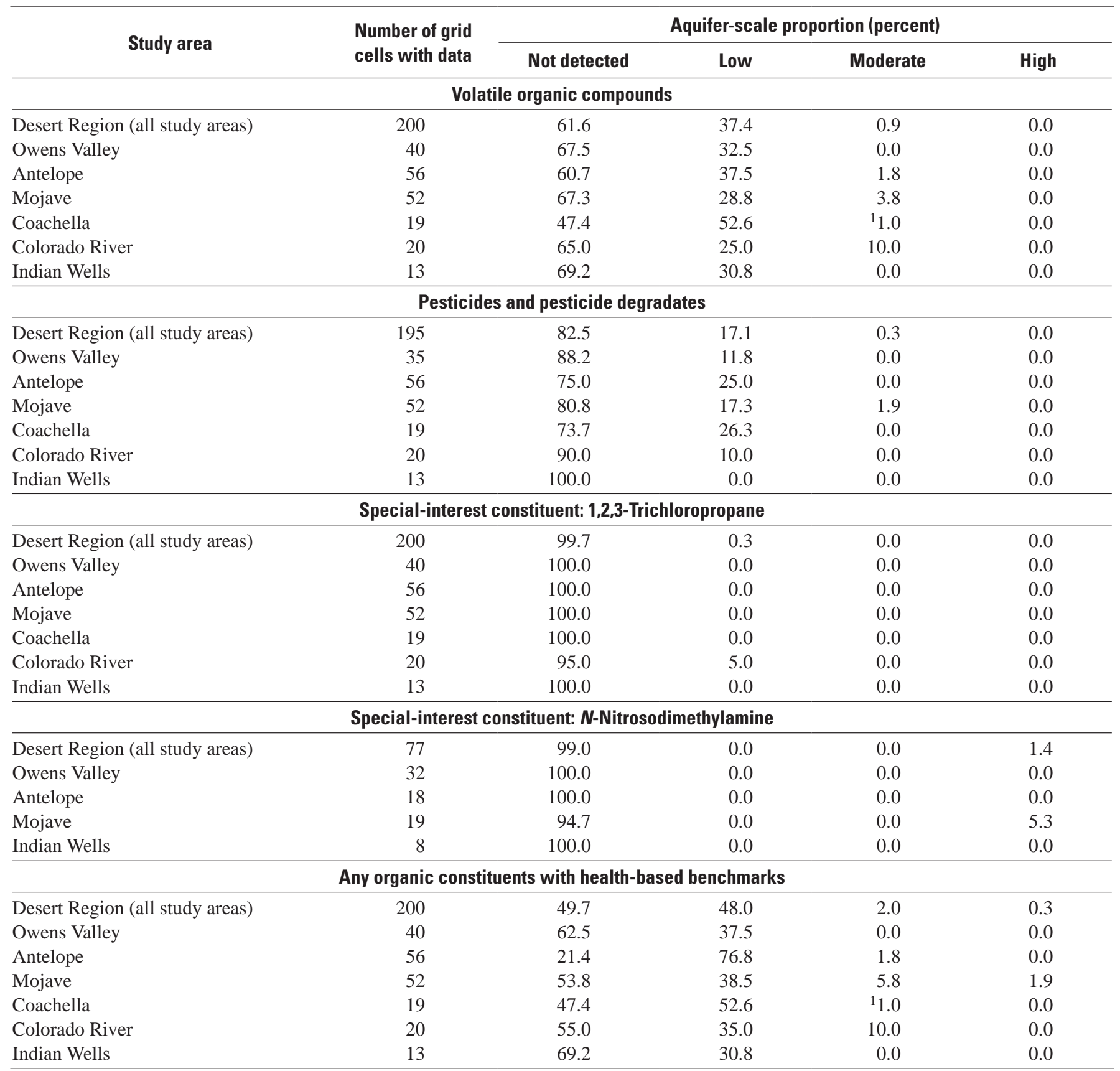

\footnotetext{
${ }^{1}$ Spatially weighted value.
} 


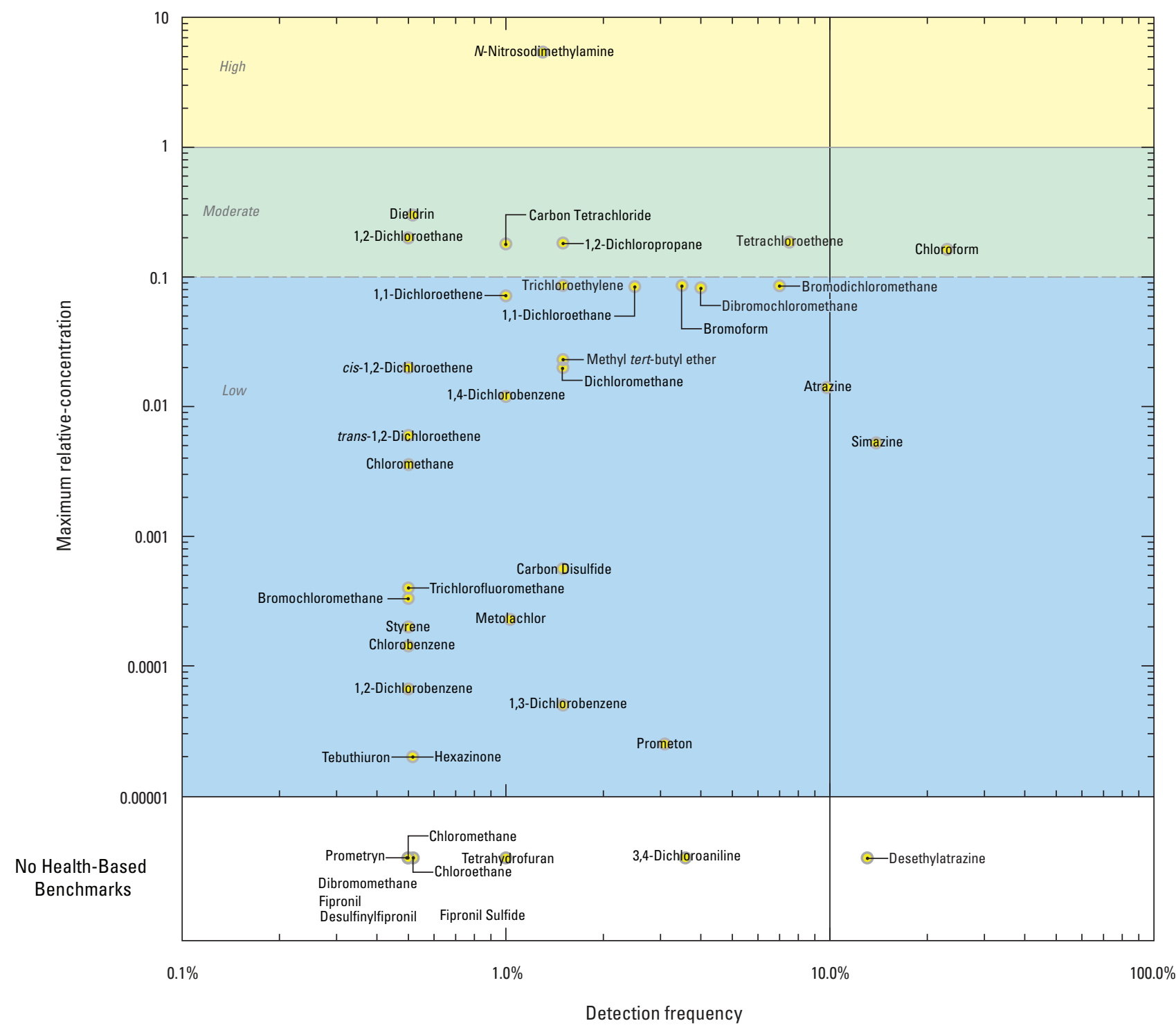

Figure 25. Detection frequencies and maximum relative-concentrations for organic constituents detected in grid wells in the California Desert Region Groundwater Ambient Monitoring and Assessment (GAMA) study areas, 2006-2008. 


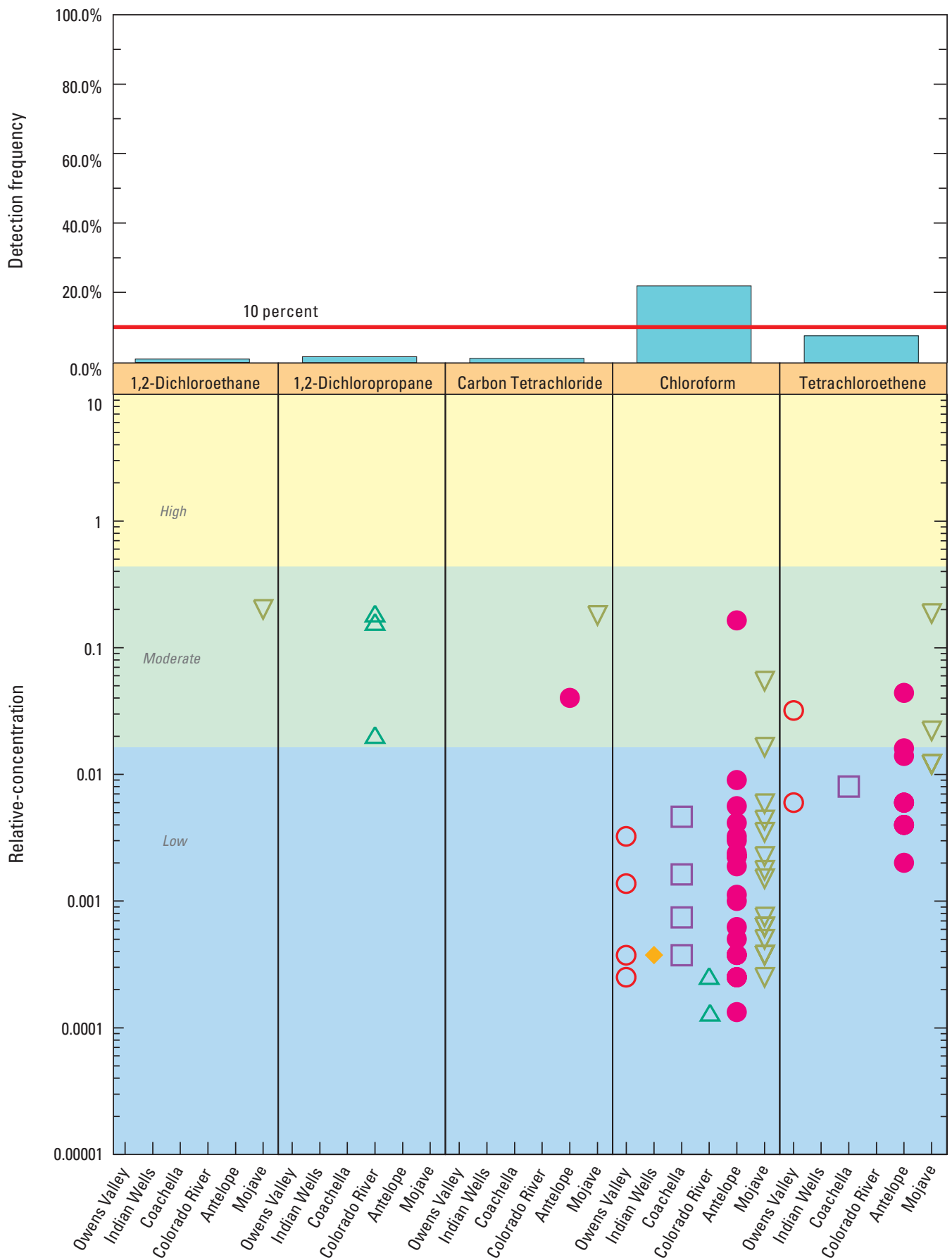

Figure 26. Concentrations relative to health-based benchmarks and detection frequencies of volatile organic compounds in grid wells in the California Desert Region Groundwater Ambient Monitoring and Assessment (GAMA) study areas, 2006-2008. 


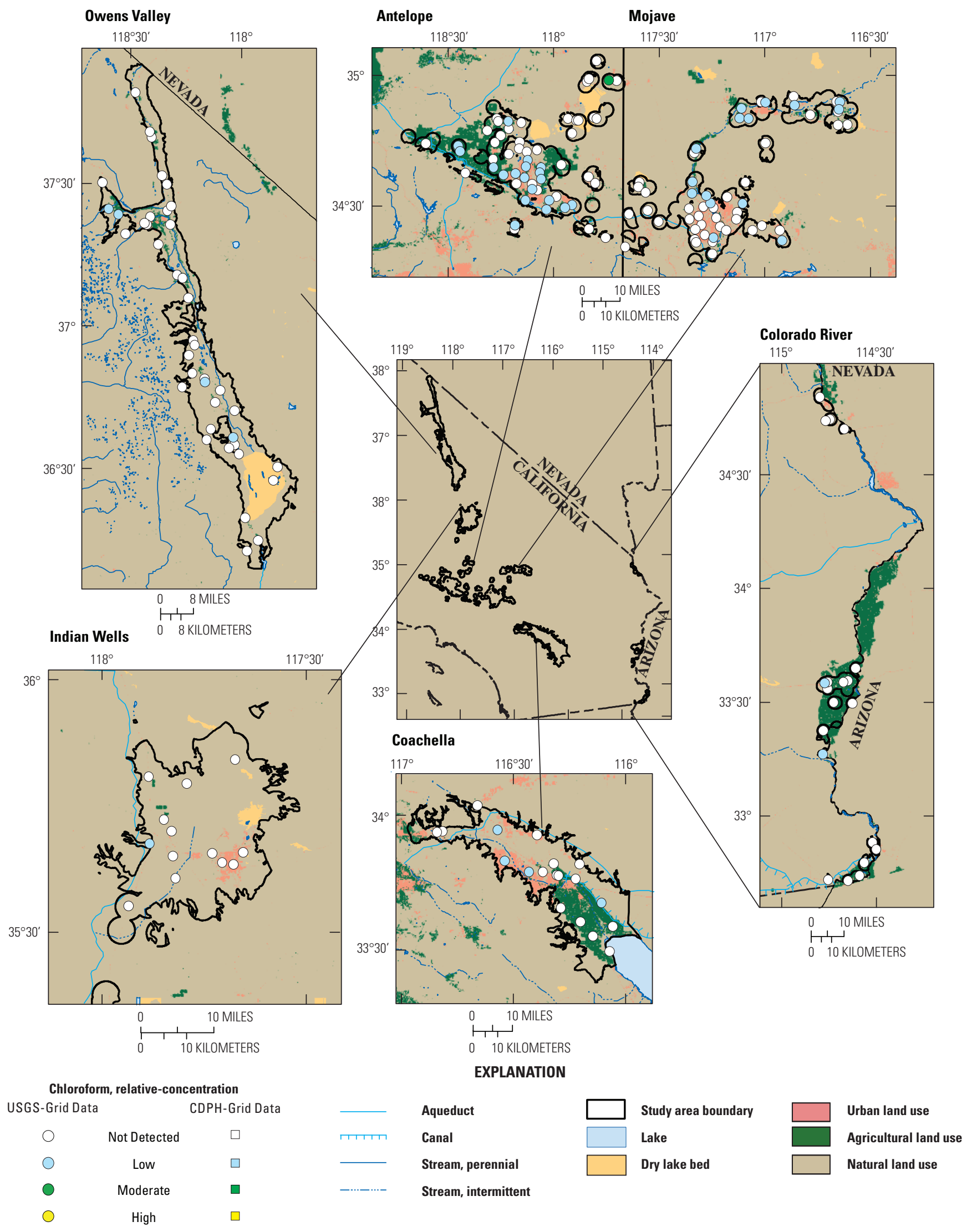

Figure 27. Concentrations of chloroform relative to health-based benchmarks in the California Desert Region Groundwater Ambient Monitoring and Assessment (GAMA) study areas, 2006-2008. 


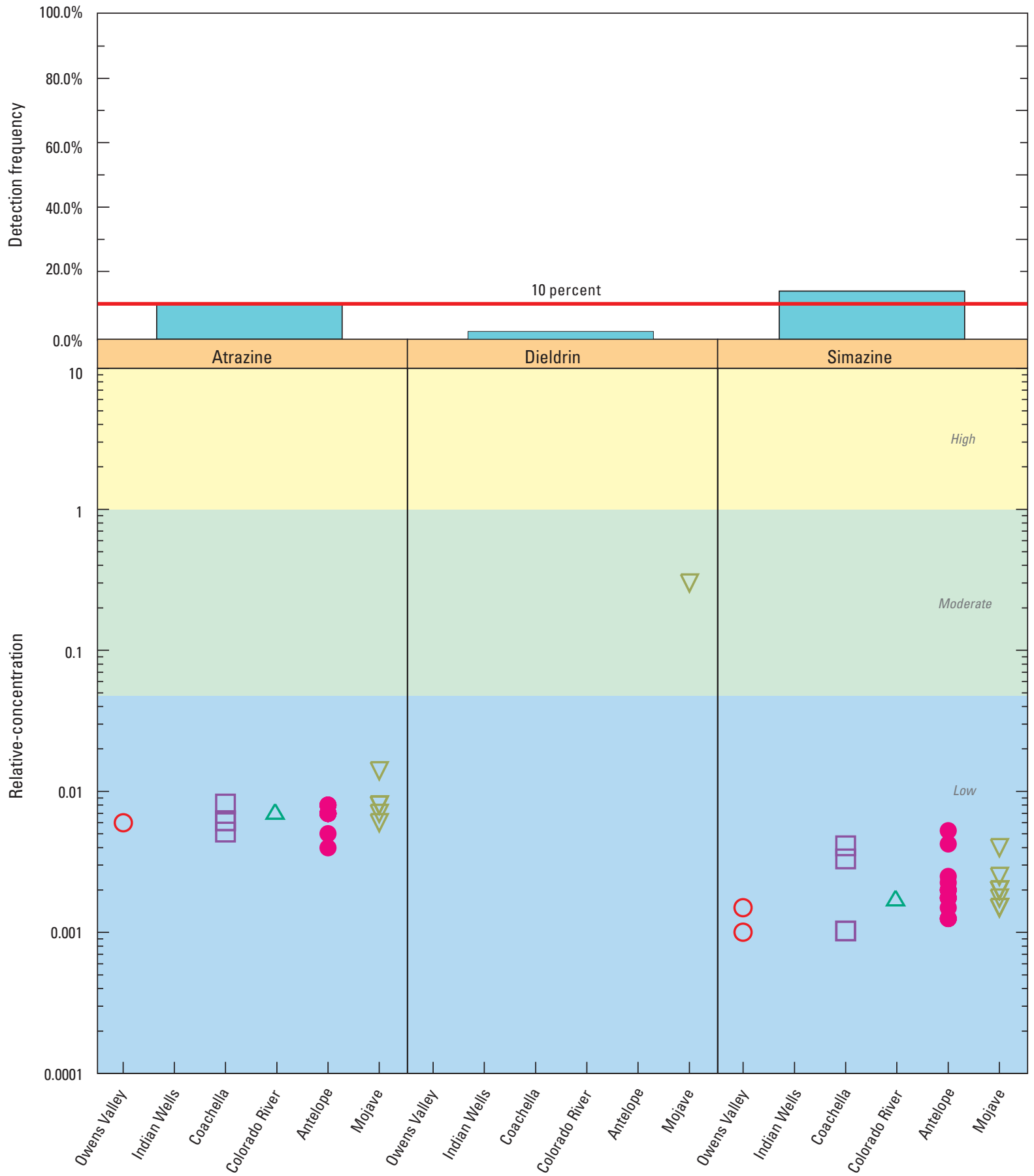

Figure 28. Concentrations relative to health-based benchmarks and detection frequencies of pesticide compounds in grid wells in the California Desert Region Groundwater Ambient Monitoring and Assessment (GAMA) study areas, 2006-2008. 


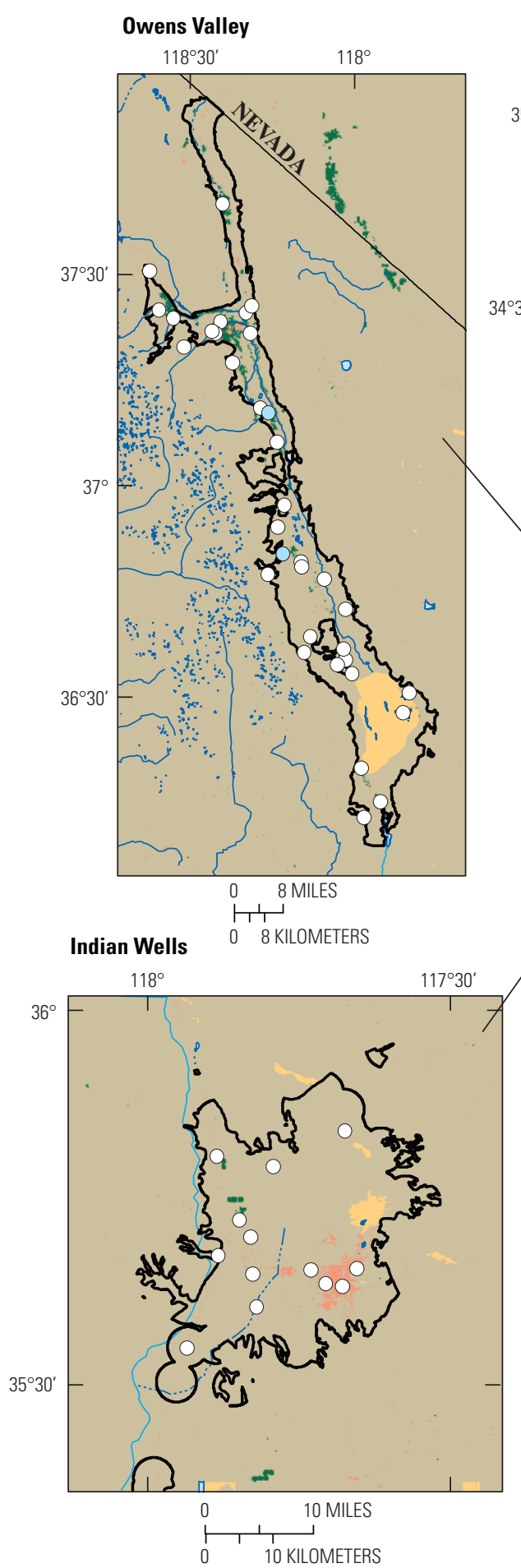

Simazine and Dieldrin, relative-concentration
Antelope Mojave

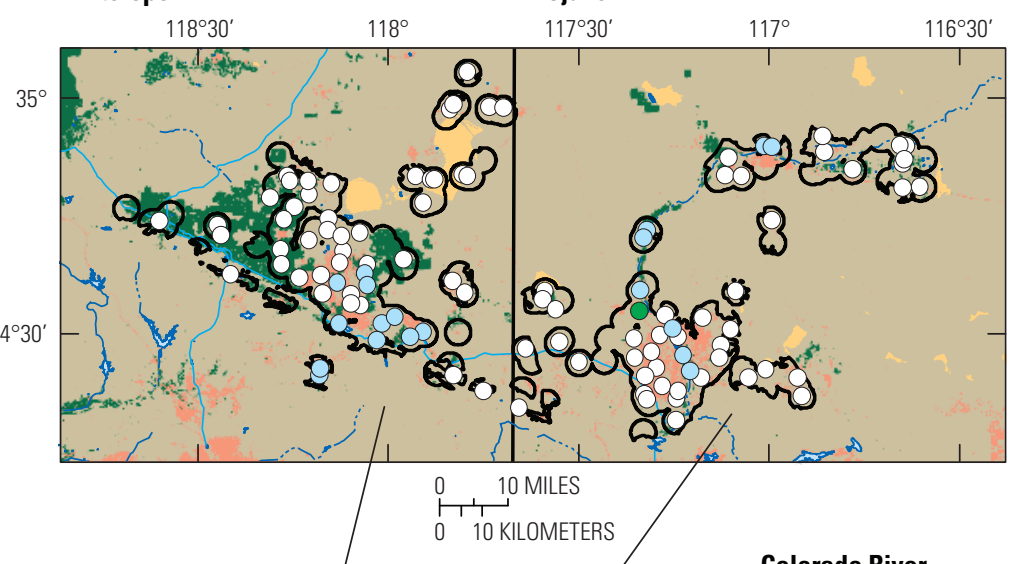

Colorado River
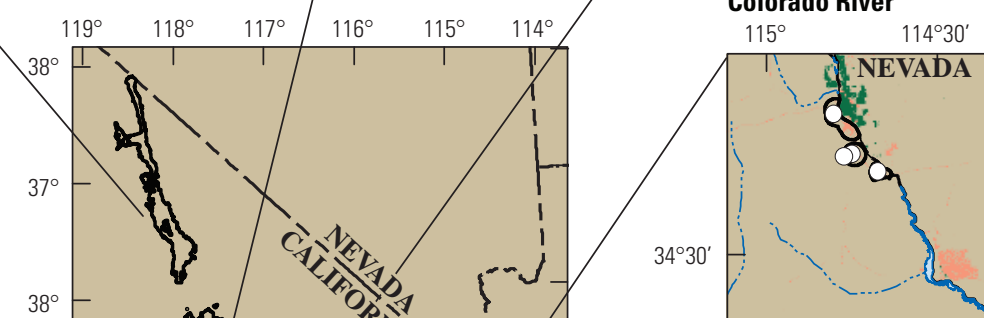

$33^{\circ}$

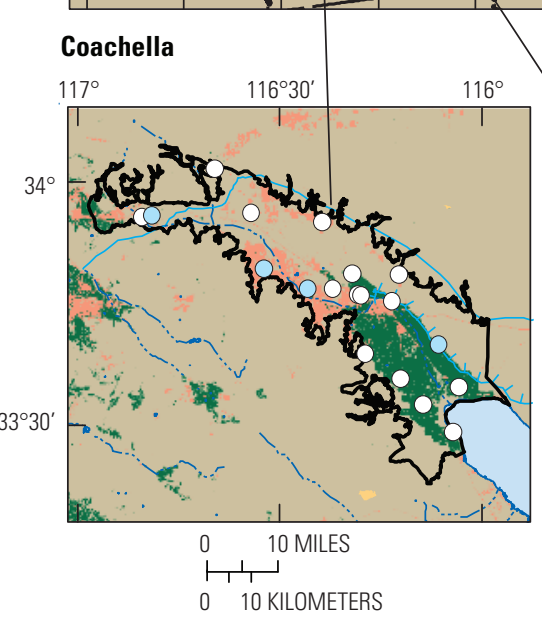

\begin{tabular}{llll}
\multicolumn{1}{c}{ USGS-Grid Data } & - & Aqueduct \\
Not Detected & $-1,1$ & Canal \\
\hline & Simazine, Low & - & Stream, perennial \\
\hline & Simazine, Low; Dieldrin, Moderate & $-\cdots \ldots-\cdots$ & Stream, intermittent
\end{tabular}
USGS-Grid Data

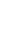

Figure 29. Concentrations of dieldrin and simazine relative to health-based benchmarks in the California Desert Region Groundwater Ambient Monitoring and Assessment (GAMA) study areas, 2006-2008. 


\section{Special-Interest Constituents}

Two organic special-interest constituents were analyzed in samples from the Desert Region. 1,2,3-Trichloropropane was sampled at all wells and was analyzed at laboratory reporting levels of 0.12 to 0.18 micrograms per liter (Densmore and others, 2009; Goldrath and others, 2009, 2010; Mathany and Belitz, 2009; Schmitt and others, 2009). At 94 wells, additional samples were analyzed for 1,2,3-trichloropropane at a method detection level of 0.005 microgram per liter. It was detected in one well in COL at a low RC.

$\mathrm{N}$-Nitrosodimethylamine (NDMA) was analyzed in samples collected in four study areas (OV, IW, ANT, MOJ). NDMA was detected at a high RC in one grid well in MOJ (figs. 30 and $\underline{31}$ ), equivalent to 1.4 percent of the Desert Region's primary aquifers (table 7). This was the only detection of an organic constituent above a health-based benchmark.

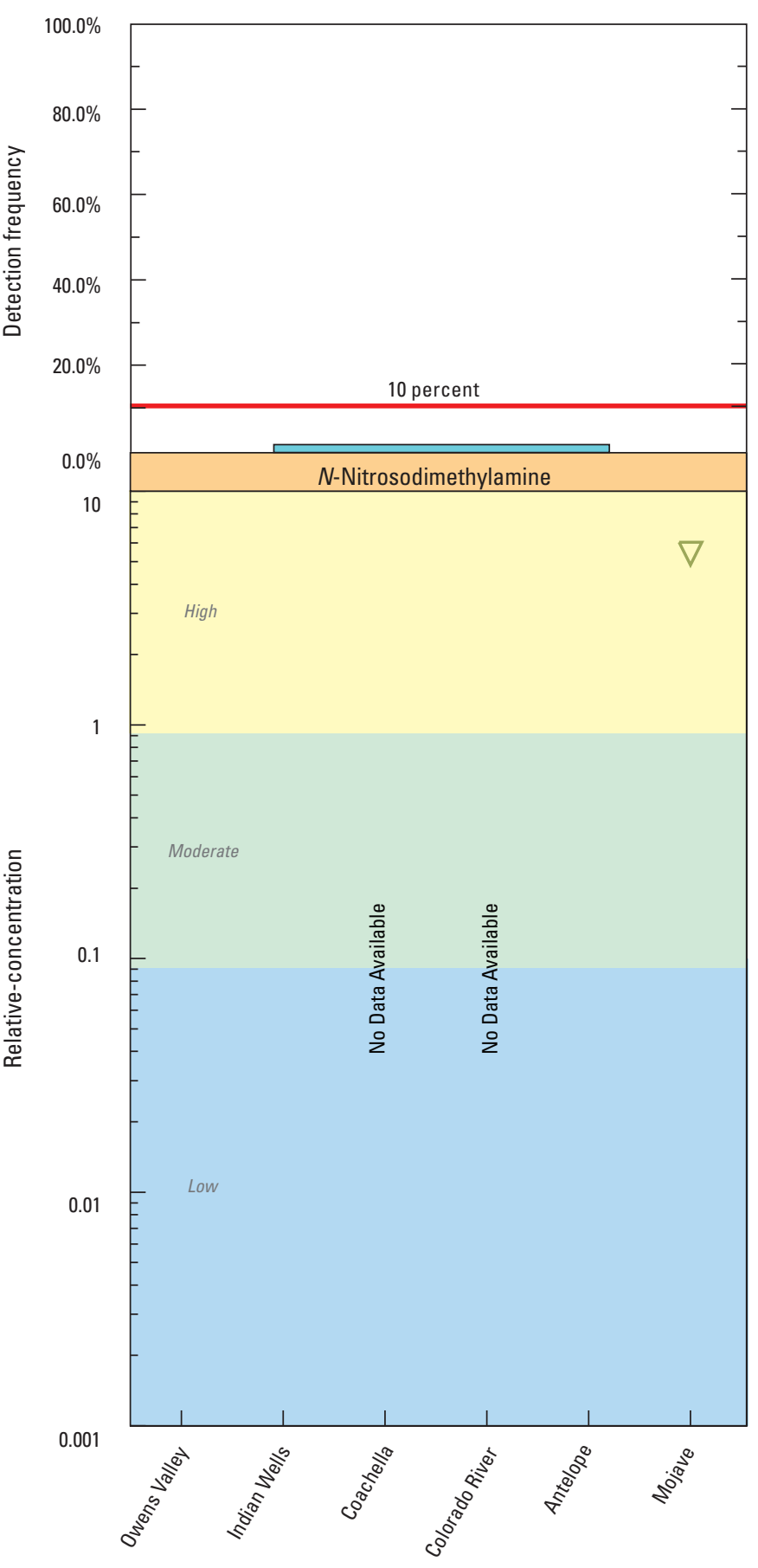

Figure 30. Detection frequency and concentrations of $\mathrm{N}$-nitrosodimethylamine in 77 grid wells relative to health-based benchmarks in the California Desert Region Groundwater Ambient Monitoring and Assessment (GAMA) study areas, 2006-2008. 


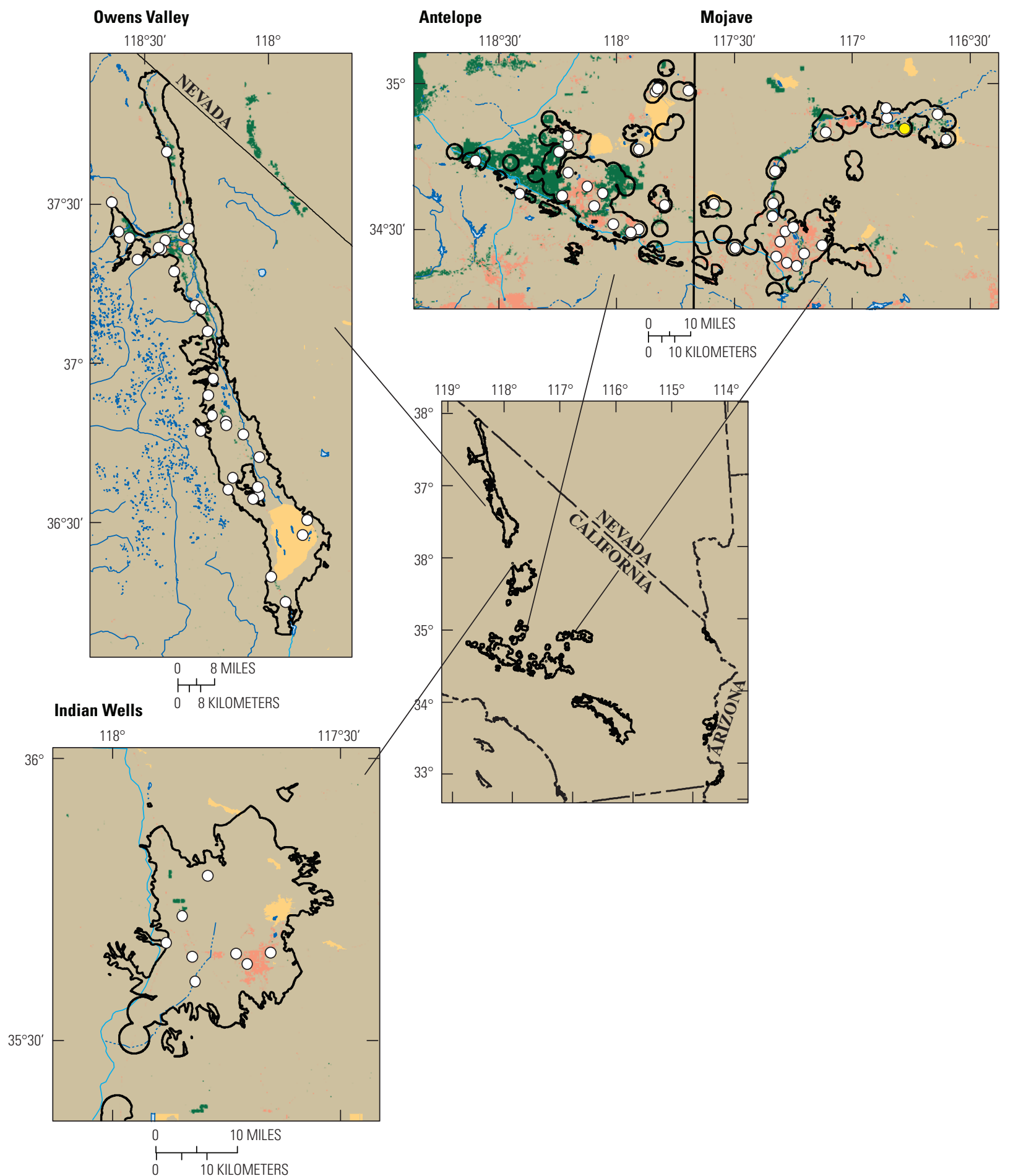

EXPLANATION

$N$-nitrosodimethylamine, relative-concentration

\begin{tabular}{|c|c|c|c|c|}
\hline USGS-Grid Data & $\longrightarrow$ & Aqueduct & Study area boundary & Urban land use \\
\hline Not Detected & חדודוד & Canal & Lake & Agricultural land use \\
\hline High & $\longrightarrow$ & Stream, perennial & Dry lake bed & Natural land use \\
\hline
\end{tabular}

Figure 31. Concentrations of $N$-nitrosodimethylamine relative to health-based benchmarks in the California Desert Region Groundwater Ambient Monitoring and Assessment (GAMA) study areas, 2006-2008. 


\section{Summary}

Groundwater quality in six California Desert Region study areas, covering approximately 6,050 square miles $\left(\mathrm{mi}^{2}\right)$ [15,670 square kilometers $\left.\left(\mathrm{km}^{2}\right)\right]$ was investigated by the U.S. Geological Survey (USGS) as part of the Priority Basin Project of the Groundwater Ambient Monitoring and Assessment (GAMA) Program. Samples were collected from September 2006 through April 2008 from 253 wells in the Owens, Indian Wells, Coachella, Antelope, and Mojave Valleys, and in three Colorado River Basins.

The GAMA Priority Basin Project is designed to provide a statistically robust characterization of untreated groundwater quality in the primary aquifer at the basin-scale. Two-hundred grid wells were selected within spatially distributed, randomized grid cells in the Desert Region study areas to assess the quality of the groundwater; fifty-three wells were sampled to provide additional insight into groundwater conditions. Current (2003-2008) California Department of Public Health (CDPH) data in each study area were used to complement USGS-grid-well data and provide additional information about groundwater quality. Because of the large number of constituents, relative-concentrations (RCs) (sample concentration divided by benchmark concentration) were used as the primary metric for comparing concentrations in groundwater, for those constituents that have Federal and (or) California benchmarks. An RC greater than (>) 1.0 indicates a concentration above a benchmark, and an RC less than or equal to $(\leq) 1.0$ indicates a concentration equal to or below a benchmark. Organic and special-interest constituent RCs were classified as "low" ( RC $\leq 0.1)$, "moderate" $(0.1<\mathrm{RC}$ $\leq 1.0$ ), or "high" ( $\mathrm{RC}>1.0)$. Inorganic constituent $\mathrm{RCs}$ were classified as "low" $(\mathrm{RC} \leq 0.5)$, "moderate" $(0.5<\mathrm{RC} \leq 1.0)$, or "high" ( $\mathrm{RC}>1.0)$. A lower threshold value $\mathrm{RC}$ was used to distinguish between low and moderate RCs for organic constituents because these constituents are generally less prevalent and have smaller RCs than inorganic constituents.

Grid-based and spatially weighted statistical approaches were used to assess aquifer-scale proportions of constituents at high, moderate, and low RCs in the primary aquifers to characterize the quality of untreated groundwater. The grid-based aquifer proportions, which were based on sampling one randomly selected well per grid cell, were verified by checking that the spatially weighted results, which incorporated the CDPH data from every well in each grid cell, fell within 90 percent confidence intervals of the grid-based values.

For inorganic constituents with health-based benchmarks, 35.4 percent of the Desert Region's primary aquifers had high RCs of at least one constituent, 27.4 percent had moderate RCs, and 37.2 percent had low RCs. Inorganic constituents detected at high concentrations relative to health-based benchmarks were arsenic, boron, fluoride, gross-alpha radioactivity, molybdenum, nitrate, strontium, uranium, and vanadium. Inorganic constituents detected at high concentrations relative to non-health-based benchmarks were chloride, iron, manganese, sulfate, and total dissolved solids. A special-interest constituent, perchlorate, was also detected at high RCs.

In contrast to the aquifer-scale proportions for high inorganic constituents, organic constituents were detected at high concentrations in only 0.3 percent of the Desert Region's primary aquifers. The proportion of the Desert Region's primary aquifers having moderate concentrations of organic constituents was 2 percent, and 48 percent had low concentrations or no detections. No organic constituents with health-based benchmarks were detected in 49.7 percent of the Desert Region's primary aquifers.

\section{Acknowledgments}

The authors thank the following cooperators for their support: the California State Water Resources Control Board, Lawrence Livermore National Laboratory, California Department of Public Health, and California Department of Water Resources. We especially thank the well owners and water purveyors for their generosity in allowing the U.S. Geological Survey to collect samples from their wells. Funding for this work was provided by State of California bonds authorized by Proposition 50 and administered by the California State Water Resources Control Board.

\section{References}

Belitz, K., Dubrovsky, N.M., Burow, K.R., Jurgens, B., and Johnson, T., 2003, Framework for a ground-water quality monitoring and assessment program for California: U.S. Geological Survey Water-Resources Investigations Report 03-4166, 28 p.

Belitz, Kenneth, Jurgens, B., Landon, M.K., Fram, M.S., and Johnson, T., 2010, Estimation of aquifer scale proportion using equal area grids-Assessment of regional scale groundwater quality: Water Resources Research, v. 46, W11550, doi:10.1029/2010WR009321.

Berenbrock, C., and Martin, P., 1991, The ground-water flow system in Indian Wells Valley, Kern, Inyo, and San Bernardino Counties, California: U.S. Geological Survey Water-Resources Investigations Report 89-4191, 81 p.

Berenbrock, C., and Schroeder, R.A., 1994, Ground-water flow and quality, and geochemical processes, in Indian Wells Valley, Kern, Inyo, and San Bernardino Counties, California, 1987-88: U.S. Geological Survey WaterResources Investigations Report 93-4003, 59 p. 
Bishop, C.C., 1963, Geologic map of California, Needles Sheet: California Division of Mines and Geology, scale 1:250,000, accessed March 13, 2012, at http://ngmdb.usgs. gov/ngm-bin/ILView.pl?sid=41 1.sid\&vtype=b.

Brown, L.D., Cai, T.T., and DasGupta, A., 2001, Interval estimation for a binomial proportion: Statistical Science, v. 16, no. 2, p. 101-117.

California Department of Public Health, 2008, Maximum contaminant levels and regulatory dates for drinking water, U.S. EPA vs California, November 2008, accessed August 4, 2011, at http://www.cdph.ca.gov/certlic/drinkingwater/ Documents/DWdocuments/EPAandCDPH-11-28-2008.pdf.

California Department of Public Health, 2010a, Drinking water notification levels and response levels-An overview, accessed August 4, 2011, at http://www.cdph.ca.gov/ certlic/drinkingwater/Documents/Notificationlevels/ NotificationLevels.pdf.

California Department of Public Health, 2010b, Title 22 of California Code of Regulations, accessed August 4, 2011, at http://www.cdph.ca.gov/certlic/drinkingwater/Pages/ Lawbook.aspx.

California Department of Water Resources, 1979, Sources of powerplant cooling water in the desert area of southern California-Reconnaissance study: California Department of Water Resources Bulletin 118, 135 p.

California Department of Water Resources, 2003, California's groundwater: California Department of Water Resources Bulletin 118, update 2003, 265 p., accessed March 13, 2012, at http://www.water.ca.gov/pubs/groundwater/bulletin 118/ california's groundwater bulletin 118 - update 2003 / bulletin118 entire.pdf.

California Department of Water Resources, 2004a, California's groundwater: California Department of Water Resources Bulletin 118, Owens Valley Groundwater Basin, 5 p., accessed April 10, 2012, at http://www.water.ca.gov/pubs/ groundwater/bulletin 118/basindescriptions/6-12.pdf.

California Department of Water Resources, 2004b, California's groundwater: California Department of Water Resources Bulletin 118, Antelope Valley Groundwater Basin, 4 p., accessed April 10, 2012, at http://www.water.ca.gov/pubs/groundwater/bulletin_118/ basindescriptions/6-44.pdf.

California Department of Water Resources, 2004c, California's groundwater: California Department of Water Resources Bulletin 118, Upper Mojave River Valley Groundwater Basin, 7 p., accessed April 10, 2012, at http://www.water.ca.gov/pubs/groundwater/bulletin 118/ basindescriptions/6-42.pdf.
California Department of Water Resources, 2004d, California's groundwater: California Department of Water Resources Bulletin 118, Middle Mojave River Valley Groundwater Basin, 6 p., accessed April 10, 2012, at http://www.water.ca.gov/pubs/groundwater/bulletin 118/ basindescriptions/6-41.pdf.

California Department of Water Resources, 2004e, California's groundwater: California Department of Water Resources Bulletin 118, Lower Mojave River Valley Groundwater Basin, 6 p., accessed April 10, 2012, at http://www.water.ca.gov/pubs/groundwater/bulletin 118/ basindescriptions/6-40.pdf.

California Department of Water Resources, 2004f, California's groundwater: California Department of Water Resources Bulletin 118, El Mirage Valley Groundwater Basin, 4 p., accessed April 10, 2012, at http://www.water.ca.gov/pubs/ groundwater/bulletin 118/basindescriptions/6-43.pdf.

California Department of Water Resources, 2004g, California's groundwater: California Department of Water Resources Bulletin 118, Coachella Valley Groundwater Basin, Desert Hot Springs Subbasin, 5 p., accessed April 10, 2012, at http://www.water.ca.gov/pubs/groundwater/ bulletin 118/basindescriptions/7-21.03.pdf.

California Department of Water Resources, 2004h, California's groundwater: California Department of Water Resources Bulletin 118, Coachella Valley Groundwater Basin, Indio Subbasin, 5 p., accessed April 10, 2012, at http://www.water.ca.gov/pubs/groundwater/bulletin 118/ basindescriptions/7-21.01.pdf.

California Department of Water Resources, 2004i, California's groundwater: California Department of Water Resources Bulletin 118, Coachella Valley Groundwater Basin, Mission Creek Subbasin, 4 p., accessed April 10, 2012, at http://www.water.ca.gov/pubs/groundwater/bulletin_118/ basindescriptions/7-21.02.pdf.

California Department of Water Resources, 2004j, California's groundwater: California Department of Water Resources Bulletin 118, Coachella Valley Groundwater Basin, San Gorgonio Pass Subbasin, 4 p., accessed April 10, 2012, at http://www.water.ca.gov/pubs/groundwater/bulletin 118/ basindescriptions/7-21.04.pdf.

California Department of Water Resources, 2004k, California's groundwater: California Department of Water Resources Bulletin 118, Needles Valley Groundwater Basin, 3 p., accessed April 10, 2012, at http://www.water.ca.gov/ pubs/groundwater/bulletin 118/basindescriptions/7-44.pdf.

California Department of Water Resources, 2004l, California's groundwater: California Department of Water Resources Bulletin 118, Palo Verde Valley Groundwater Basin, 4 p., accessed April 10, 2012, at http://www.water.ca.gov/pubs/ groundwater/bulletin 118/basindescriptions/7-38.pdf. 
California Department of Water Resources, 2004m, California's groundwater: California Department of Water Resources Bulletin 118, Palo Verde Mesa Groundwater Basin, 3 p., accessed April 10, 2012, at http://www.water.ca.gov/pubs/groundwater/bulletin 118/ basindescriptions/7-39.pdf.

California Department of Water Resources, 2004n, California's groundwater: California Department of Water Resources Bulletin 118, Yuma Valley Groundwater Basin, 3 p., accessed April 10, 2012, at http://www.water.ca.gov/ pubs/groundwater/bulletin 118/basindescriptions/7-36.pdf.

California Department of Water Resources, 2004o, California's groundwater: California Department of Water Resources Bulletin 118, Indian Wells Valley Groundwater Basin, 5 p., accessed April 10, 2012, at http://www.water.ca.gov/pubs/groundwater/bulletin 118/ basindescriptions/6-54.pdf.

Danskin, W.R., 1998, Evaluation of the hydrologic system and selected water-management alternatives in the Owens Valley, California: U.S. Geological Survey Water-Supply Paper 2370, 175 p.

Davis, S.N., and DeWiest, R.J., 1966, Hydrogeology: New York, John Wiley and Sons, 413 p.

Densmore, J.N., Fram, M.S., and Belitz, Kenneth, 2009, Ground-water quality data in the Owens and Indian Wells Valleys study unit, 2006-Results from the California GAMA Program: U.S. Geological Survey Data Series 427, 86 p. Available at http://pubs.usgs.gov/ds/427.

Duell, L.F.W., Jr., 1987, Geohydrology of the Antelope Valley area, California, and design for a ground-water-quality monitoring network: U.S. Geological Survey WaterResources Investigations Report 84-4081, 72 p.

Durbin, T.J., 1978, Calibration of a mathematical model of the Antelope Valley ground-water basin, California: U.S. Geological Survey Water-Supply Paper 2046, 51 p.

Gilliom, R.J., Barbash, J.E., Crawford, C.G., Hamilton, P.A., Martin, J.D., Nakagaki, N., Nowell, L.H., Scott, J.C., Stackelberg, P.E., Thelin, G.P., and Wolock, D.M., 2006, The quality of our nation's waters-Pesticides in the nation's streams and ground water, 1992-2001: U.S. Geological Survey Circular 1291, 172 p.

Goldrath, D.A., Wright, M.T., and Belitz, Kenneth, 2009, Ground-water quality data in the Coachella Valley study unit, 2007-Results from the California GAMA Program: U.S. Geological Survey Data Series 373, 70 p. Available at http://pubs.usgs.gov/ds/373.
Goldrath, D.A., Wright, M.T., and Belitz, Kenneth, 2010, Groundwater-quality data in the Colorado River study unit, 2007—Results from the California GAMA Program: U.S. Geological Survey Data Series 474, 66 p. Available at http:// pubs.usgs.gov/ds/474/.

Hem, J.D., 1989, Study and interpretation of the chemical characteristics of natural water (3d ed.): U.S. Geological Survey Water-Supply Paper 2254, 213 p.

Hutson, S.S., Barber, N.L., Kenny, J.F., Linsey, K.S., Lumia, D.S., and Maupin, M.A., 2004, Estimated use of water in the United States in 2000: U.S. Geological Survey Circular 1268, 46 p.

Isaaks, E.H., and Srivastava, R.M., 1989, Applied geostatistics: New York, Oxford University Press, 511 p.

Izbicki, J.A., Clark, D.A., Pimentel, M.I., Land, M., Radyk, J., and Michel, R.L., 2000, Data from a thick unsaturated zone underlying the Oro Grande and Sheep Creek Washes in the western part of the Mojave Desert, near Victorville, San Bernardino County, California: U.S. Geological Survey Open-File Report 00-262, 133 p.

Jennings, C.W., 1967, Geologic map of California, Salton Sea Sheet, scale 1:250,000.

Johnson, T.D., and Belitz, K., 2009, Assigning land use to supply wells for the statistical characterization of regional groundwater quality - Correlating urban land use and VOC occurrence: Journal of Hydrology, v. 370, p. 100-108.

Kulongoski, J., and Belitz, K., 2004, Groundwater ambient monitoring and assessment program: U.S. Geological Survey Fact Sheet 2004-3088.

Landon, M.K., Belitz, Kenneth, Jurgens, B.C., Kulongoski, J.T., and Johnson, T.D., 2010, Status and understanding of groundwater quality in the Central-Eastside San Joaquin Basin, 2006-California GAMA Priority Basin Project: U.S. Geological Survey Scientific Investigations Report 2009-5266, 97 p.

Leighton, D.A., and Phillips, S.P., 2003, Simulation of groundwater flow and land subsidence in the Antelope Valley ground-water basin, California: U.S. Geological Survey Water-Resources Investigations Report 03-4016, 107 p.

Londquist, C.J., Rewis, D.L., Galloway, D.L., and McCaffrey, W.F., 1993, Hydrogeology and land subsidence, Edwards Air Force Base, Antelope valley, California, January 1989December 1991: U.S. Geological Survey Water-Resources Investigations Report 93-4114, 74 p.

Mathany, T.M., and Belitz, K., 2009, Groundwater quality data in the Mojave study unit, 2008-Results from the California GAMA Program: U.S. Geological Survey Data Series Report 440, 69 p. 
Mendenhall, W.C., 1909, Ground waters of the Indio region, California, with a sketch of the Colorado Desert: U.S. Geological Survey Water-Supply Paper 225, 56 p.

Metzger, D.G., and Loeltz, O.J., 1973, Geohydrology of the Needles area, Arizona, California, and Nevada: U.S. Geological Survey Professional Paper 486-J, 54 p.

Nakagaki, N., Price, C.V., Falcone, J.A., Hitt, K.J., and Ruddy, B.C., 2007, Enhanced National Land Cover Data 1992 (NLCDe 92): U.S. Geological Survey Raster digital data, accessed March 13, 2012, at http://water.usgs.gov/lookup/ getspatial?nlcde92.

Nakagaki, N., and Wolock, D.M., 2005, Estimation of agricultural pesticide use in drainage basins using land cover maps and county pesticide data: U.S. Geological Survey Open-File Report 05-1188, 46 p.

Nishikawa, T., Rewis, D.L., and Martin, P., 2001, Numerical simulation of ground-flow and land subsidence at Edwards Air Force Base, Antelope Valley, California: U.S. Geological Survey Water-Resources Investigations Report 01-4038, 111 p.

Nolan, B.T., and Hitt, K.J., 2006, Vulnerability of shallow groundwater and drinking-water wells to nitrate in the United States: Environmental Science and Technology, v. 40 , no. 24 , p. $7834-7840$.

Phillips, S.J., and Comus, P.W., eds., 2000, A natural history of the Sonoran Desert: Arizona-Sonoran Desert Museum Press, $628 \mathrm{p}$.

Piper, A.M., 1944, A graphic procedure in the geochemical interpretation of water analyses: American Geophysical Union Transactions, v. 25, p. 914-923.

PRISM Group, Oregon State University, 2007, United States average annual precipitation, maximum and minimum temperature, 1971-2000, accessed August 9, 2007, at http:// prism.oregonstate.edu/.

Putnam, J., and Smith, G., eds., 1995, Deepest Valley—Guide to Owens Valley, its roadsides and mountain trails (2d ed.): Genny Smith Books, 280 p.

Rewis, D.L., 1995, Ground-water-level monitoring, basin boundaries, and potentiometric surfaces of the aquifer system at Edwards Air Force Base, California, 1992: U.S. Geological Survey Water-Resources Investigations Report 95-4131, 61 p.

Rowe, B.L., Toccalino, P.L., Moran, M.J., Zogorski, J.S., and Price, C.V., 2007, Occurrence and potential human-health relevance of volatile organic compounds in drinking water from domestic wells in the United States: Environmental Health Perspectives, v. 115, no. 11, p. 1539-1546.
Schmitt, S.J., Milby Dawson, B.J., and Belitz, K., 2009, Groundwater-quality data in the Antelope Valley study unit, 2008-Results from the California GAMA Program: U.S. Geological Survey Data Series 479, 79 p.

Scott, J.C., 1990, Computerized stratified random siteselection approaches for design of a ground-water-quality sampling network: U.S. Geological Survey Water-Resources Investigations Report 90-4101, 109 p.

Sneed, M., and Galloway, D.L., 2000, Aquifer-system compaction and land subsidence-Measurements, analyses, and simulations-The Holly site, Edwards Air Force Base, Antelope Valley, California: U.S. Geological Survey WaterResources Investigations Report 00-4015, 65 p.

Stamos, C.L., Martin, P., Nishikawa, T., and Cox, B.F., 2001, Simulation of ground-water flow in the Mojave River basin, California: U.S. Geological Survey Water-Resources Investigations Report 01-4002, 129 p.

State Water Resources Control Board, 2003, A comprehensive groundwater quality monitoring program for California: Assembly Bill 99 Report to the Governor and Legislature, March 2003, 100 p, Accessed on April 10, 2012, at http:// www.waterboards.ca.gov/gama/docs/final_ab 599 rpt to legis 731 03.pdf.

Toccalino, P.L., and Norman, J.E., 2006, Health-based screening levels to evaluate U.S. Geological Survey ground-water quality data: Risk Analysis, v. 26, no. 5, p. 1339-1348.

Toccalino, P.L., Norman, J.E., Phillips, R.H., Kauffman, L.J., Stackelberg, P.E., Nowell, L.H., Krietzman, S.J., and Post, G.B., 2004, Application of health-based screening levels to ground-water quality data in a state-scale pilot effort: U.S. Geological Survey Scientific Investigations Report 2004-5174, 64 p.

Tyley, S.J., 1974, Analog model study of the ground-water basin of the Upper Coachella Valley, California: U.S. Geological Survey Water-Supply Paper 2027, 77 p.

U.S. Environmental Protection Agency, 1998, Code of Federal Regulations, title 40-protection of environment, chapter 1-Environmental Protection Agency, subchapter E-pesticide programs, part 159—statements of policies and interpretations, subpart D-reporting requirements for risk/benefit information, 40 CFR 159.184: National Archives and Records Administration, September 19, 1997; amended June 19, 1998, Accessed September 5, 2008, at http://www.epa.gov/EPA-PEST/1997/ September/Day-19/p24937.htm.

U.S. Environmental Protection Agency, 2000, National primary drinking water regulations; radionuclides; final rule, accessed February 2012 at https://federalregister. gov/a/00-30421. 
U.S. Environmental Protection Agency, 2011, 2011 Edition of the Drinking Water Standards and Health Advisories, updated January 2011: U.S. Environmental Protection Agency, Office of Water EPA/822-R-11-002, accessed March 14, 2012, at http://water.epa.gov/action/advisories/ drinking/upload/dwstandards2011.pdf.

U.S. Geological Survey, 2011, USGS water data for the Nation help system, parameter help, accessed March 14, 2012, at http://waterdata.usgs.gov/nwis/help?parameters help.
Zogorski, J.S., Carter, J.M., Ivahnenko, T., Lapham, W.W., Moran, M.J., Rowe, B.L., Squillace, P.J., and Toccalino, P.L., 2006, Volatile organic compounds in the Nation's ground water and drinking-water supply wells: U.S. Geological Survey Circular 1292, 101 p. 


\section{Appendix A. Use of Data From the CDPH Database}

California requires regular sampling of public-supply wells under Title 22, and historical data are available from the CDPH database. The GAMA Program used CDPH's existing monitoring data along with data collected by USGS-GAMA to characterize the primary aquifers. The CDPH database provided additional water-quality data for the grid-based and statistically weighted approaches to estimating aquifer-scale proportions for constituents. Methods for the selection and use of CDPH data are described in the following sections.

\section{Spatially Weighted Assessment}

For each constituent, the spatially weighted approach (Belitz and others, 2010) used the most recent CDPH data within the current 3-year period (table 1) for every well in a grid cell. The average of all of the data selected in a grid cell, including the USGS-grid and USGS-additional data, was calculated; this average was used as the value of that constituent for that grid cell. This average value was then divided by the constituent's respective benchmark in order to calculate that constituent's RC for the grid cell. The aquifer proportion was then calculated as the percentage of grid cells with high, moderate, or low RCs.

\section{Grid-Based Assessment}

The grid-based approach is based on a single value from a well in each grid cell. Not all inorganic constituents sampled by the USGS were sampled in every grid cell, and for some grid cells, no well was available for sampling by the USGS. To supplement the USGS dataset, the CDPH database was used to fill in the missing constituents. The CDPH wells in each cell were ranked using the same method as for the selection of the USGS-grid wells (Scott, 1990). For cells that had no USGS-grid well, the highest ranked CDPH well that had data from the current sampling period in each study area (table 1) and a cation/anion balance of less than 10 percent, a commonly used quality-assurance check for water-sample analysis (Hem, 1989), was selected to complete the grid dataset. This step resulted in the selection of CDPHgrid data to fill 14 empty grid cells. For cells that did not have a complete set of inorganic data, two selection methods were used:

1. CDPH data were selected from the same well sampled by the USGS, if it met the selection criteria used to fill empty grid cells. This step resulted in the selection of inorganic data from the CDPH database for 59 grid cells that also contain USGS data.

2. If no acceptable CPDH data were available from the same well sampled by the USGS, data from the highest ranking well located in the same grid cell, that met the same criteria, were selected. This step resulted in the selection of CDPH-grid wells for 29 grid cells.

These selection methods resulted in one set of inorganic data per cell from either the USGS database or from the CDPH database, or a combination of data from both sources for 197 of the 251 grid cells (table B1, figs. 4A-H).

Analysis of the combined USGS and CDPH datasets for the evaluation of the occurrence of relatively high or moderate concentrations was not affected by differences in laboratory reporting levels or method detection levels between USGS-collected and CDPH data because concentrations high enough to be relevant to benchmarks were generally substantially higher than the highest reporting levels. Several types of comparisons between USGS-collected and CDPH data are described in appendix C. 


\section{Appendix B. Data For Individual Desert Study Areas}




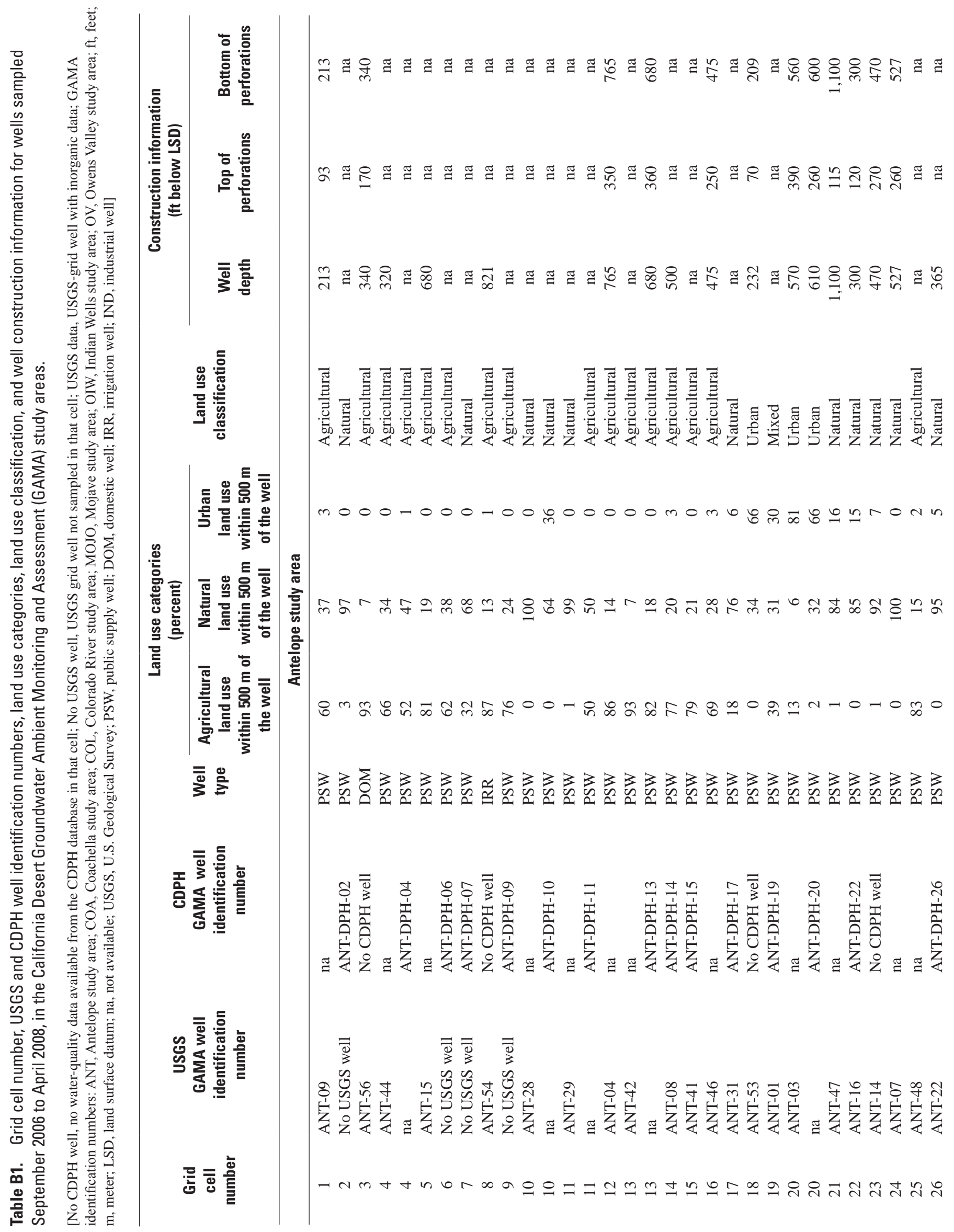




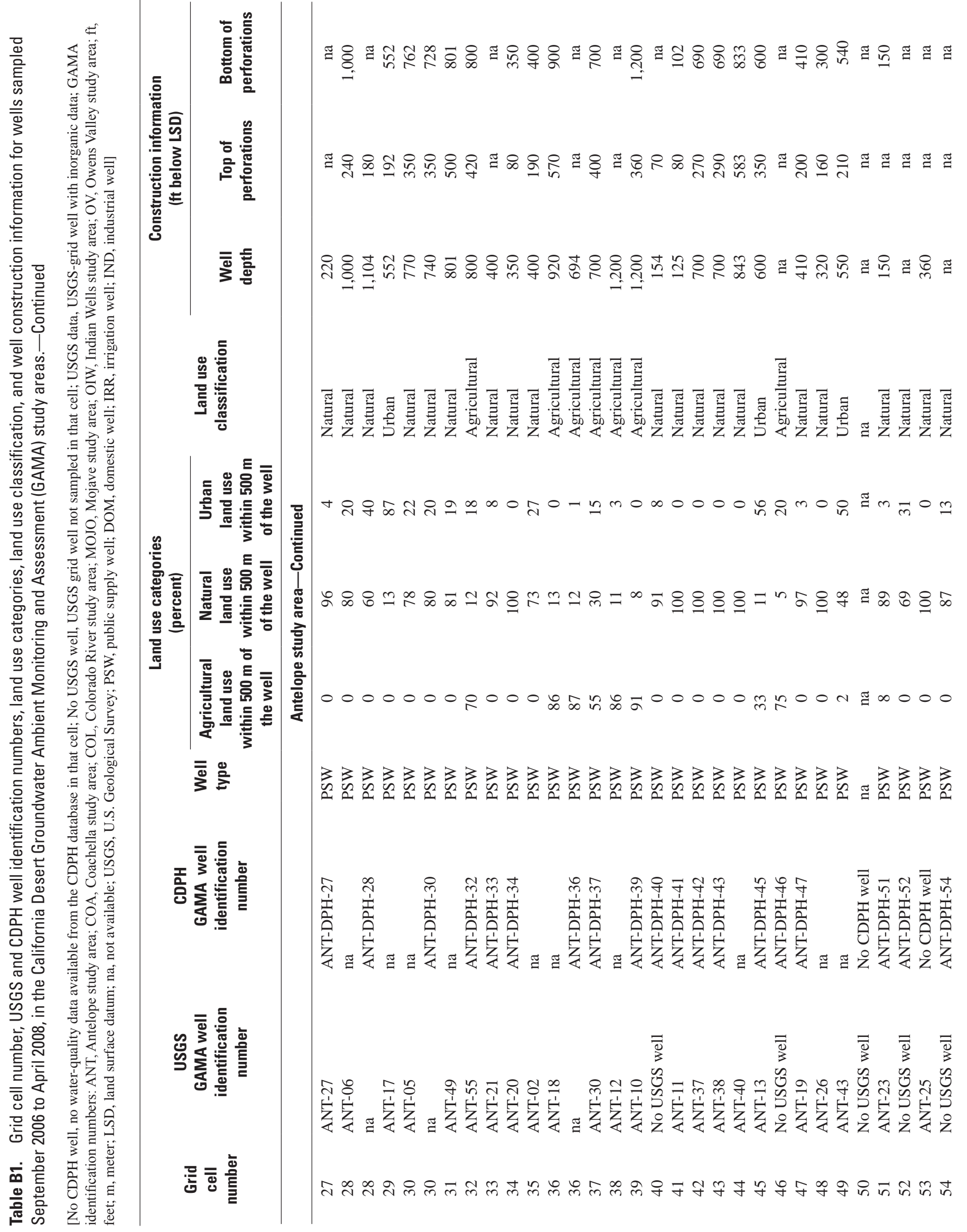




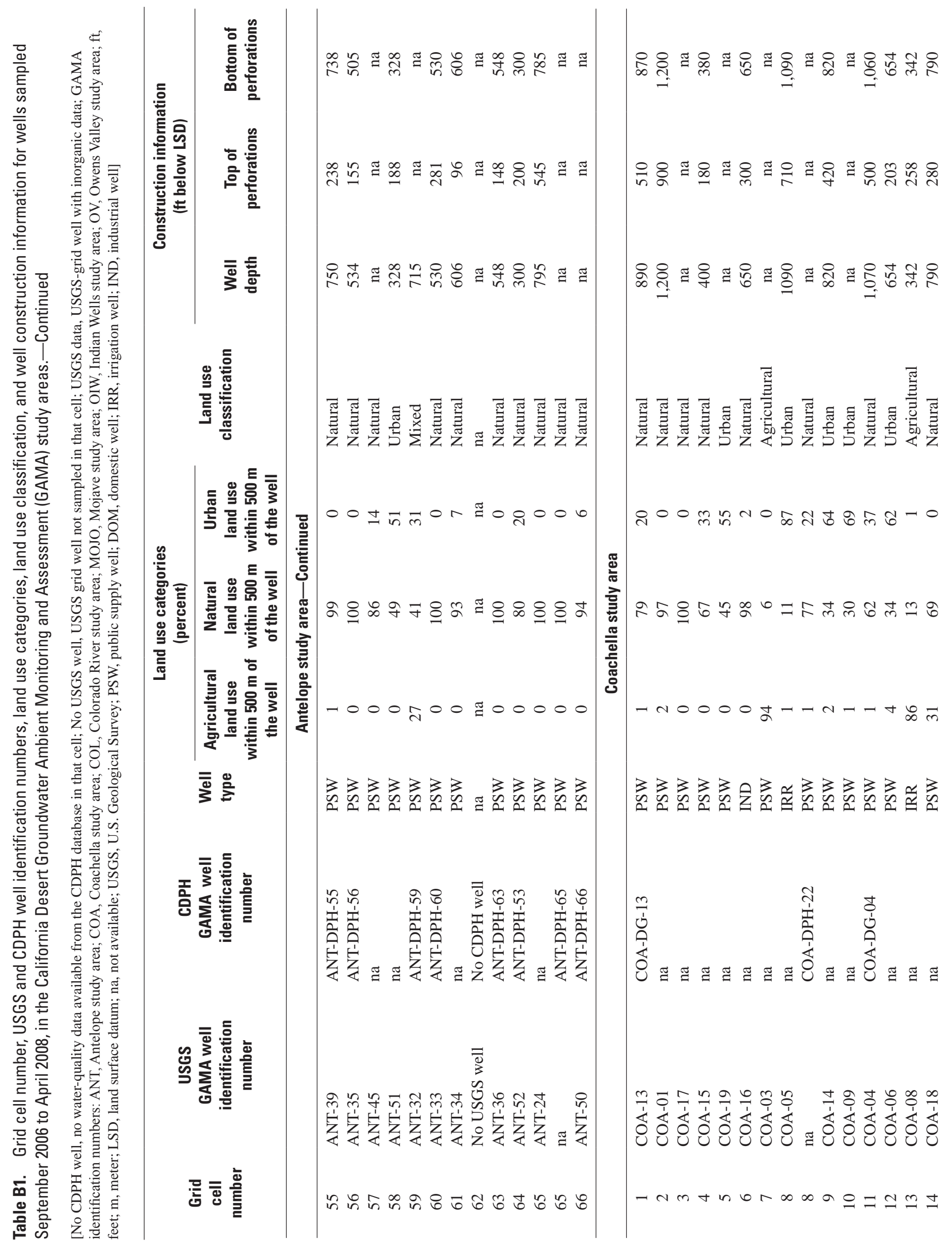




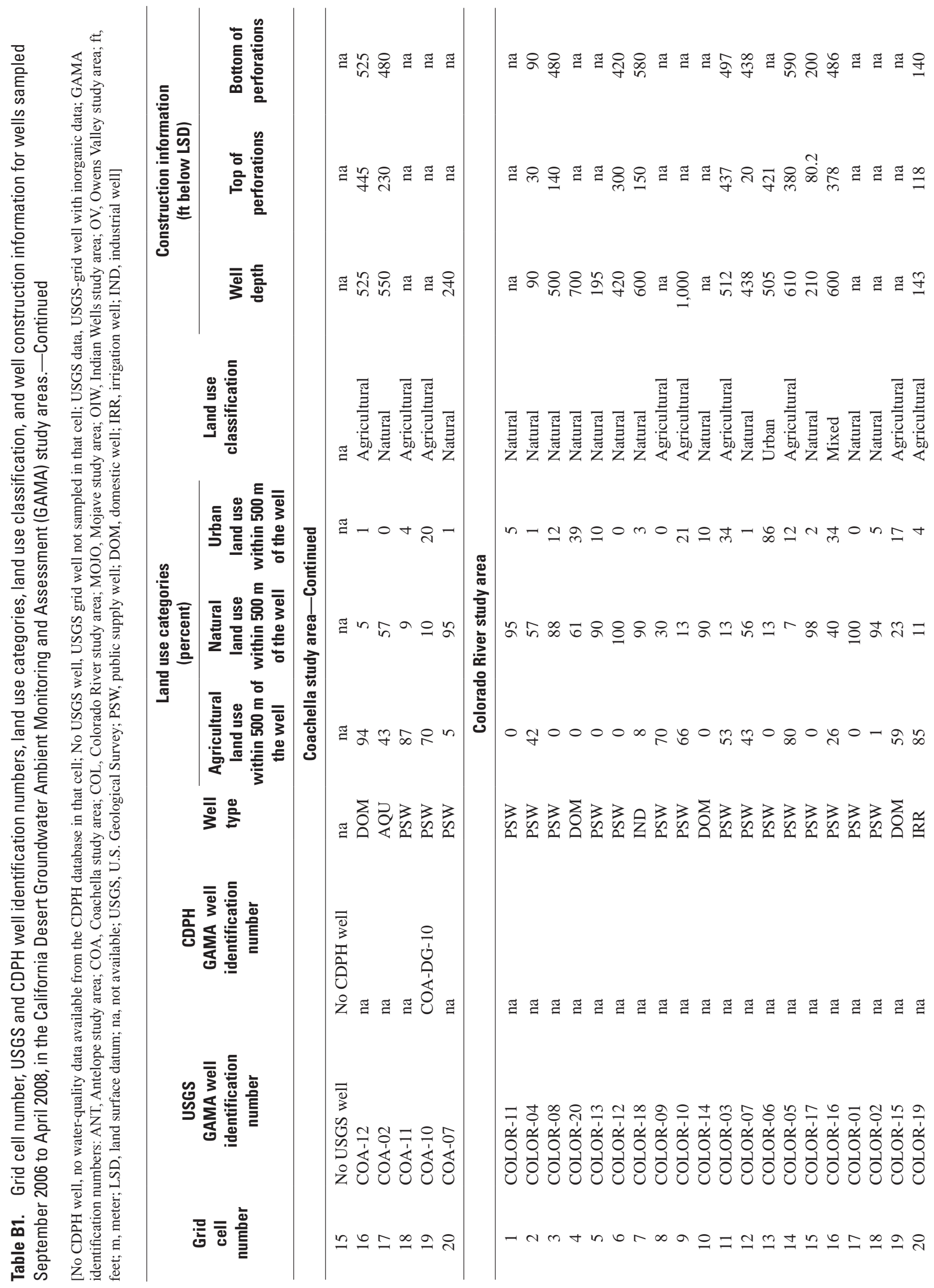




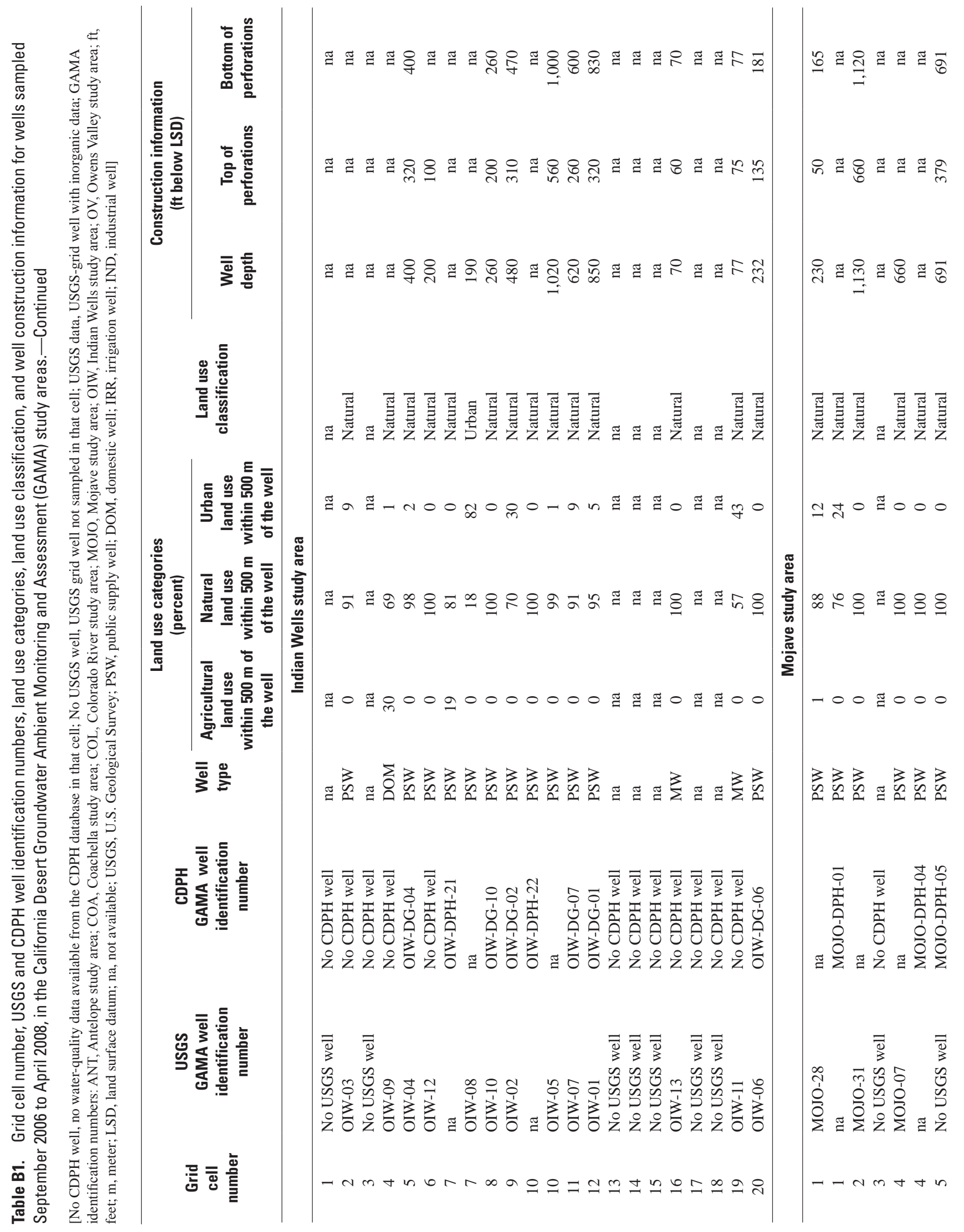




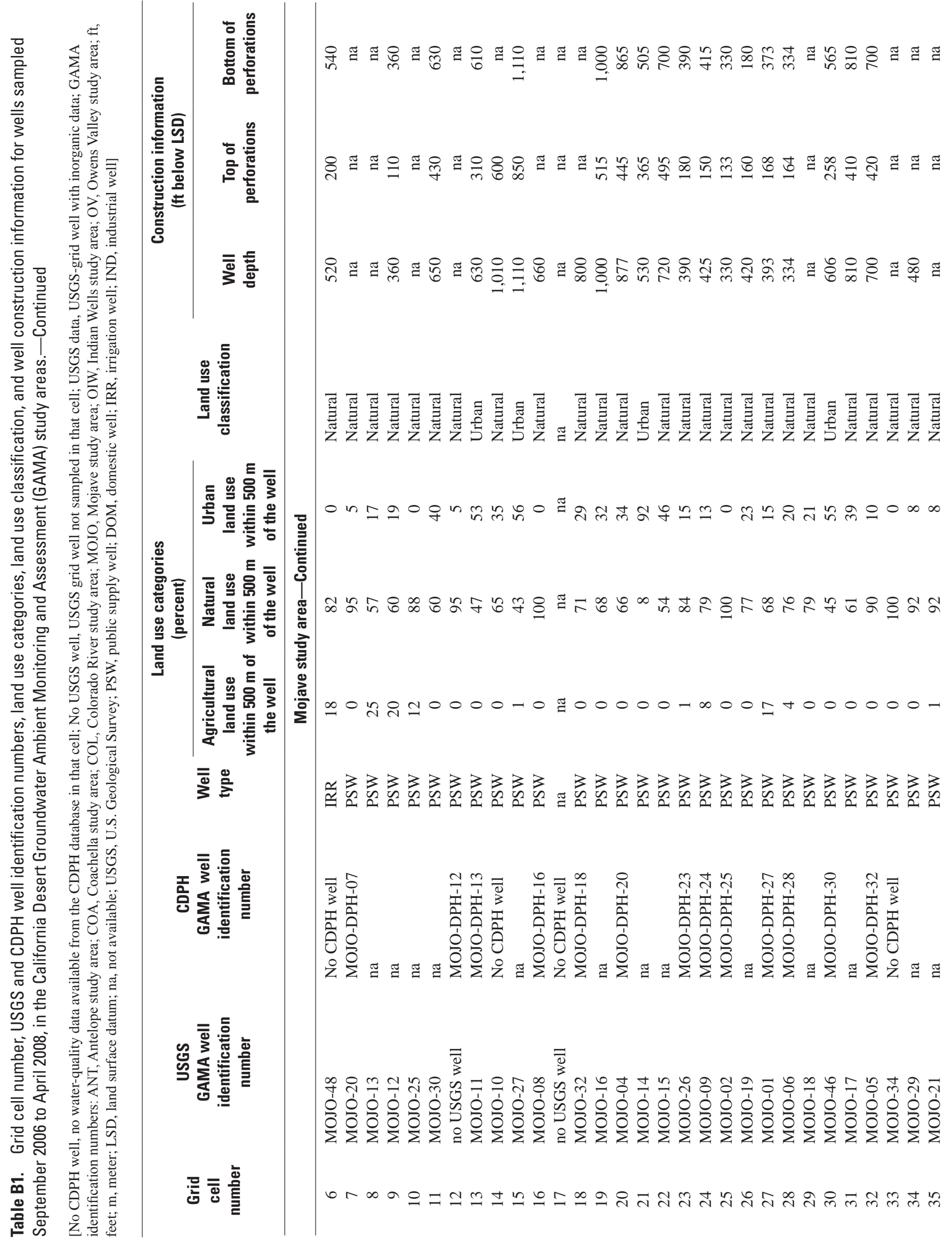




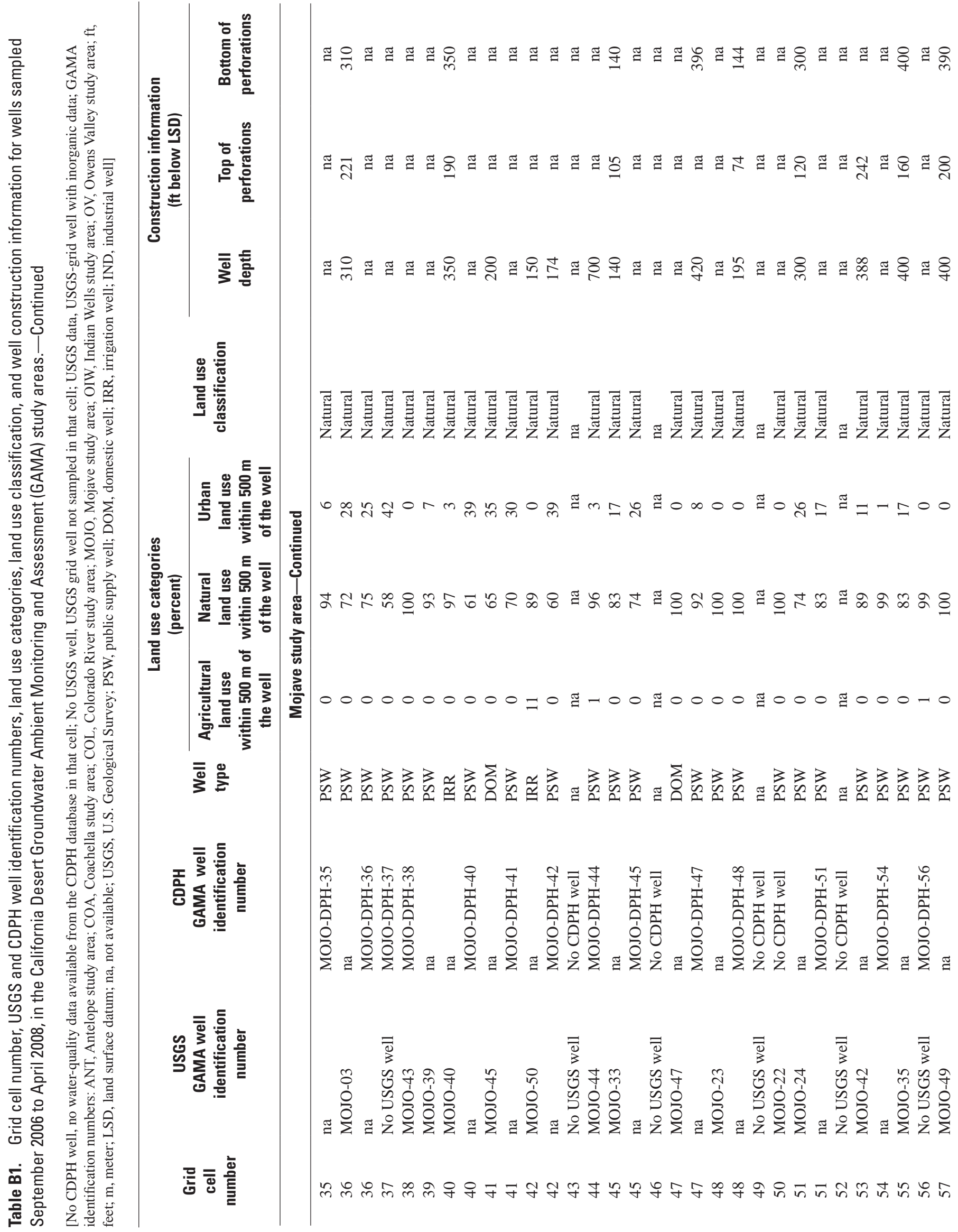




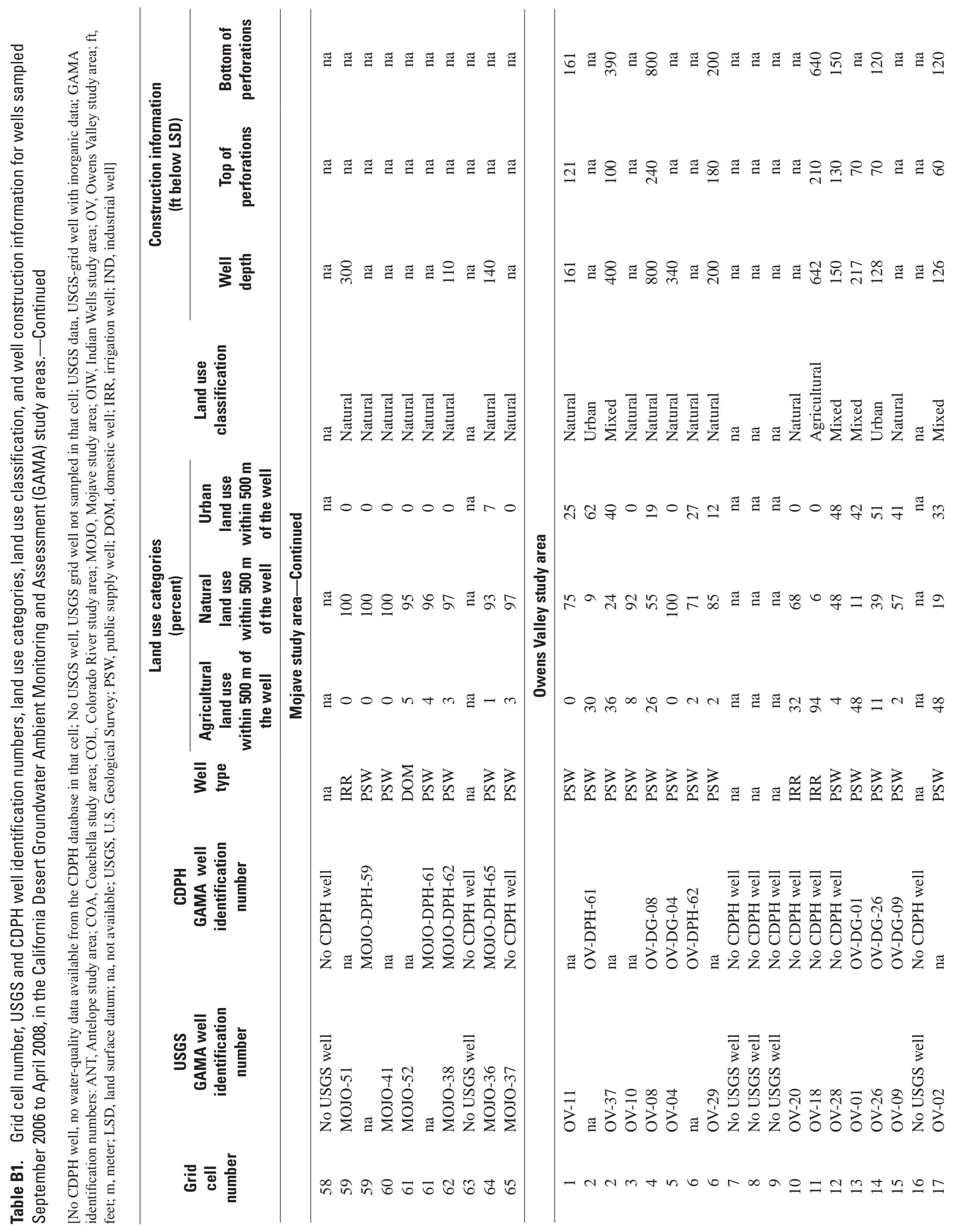




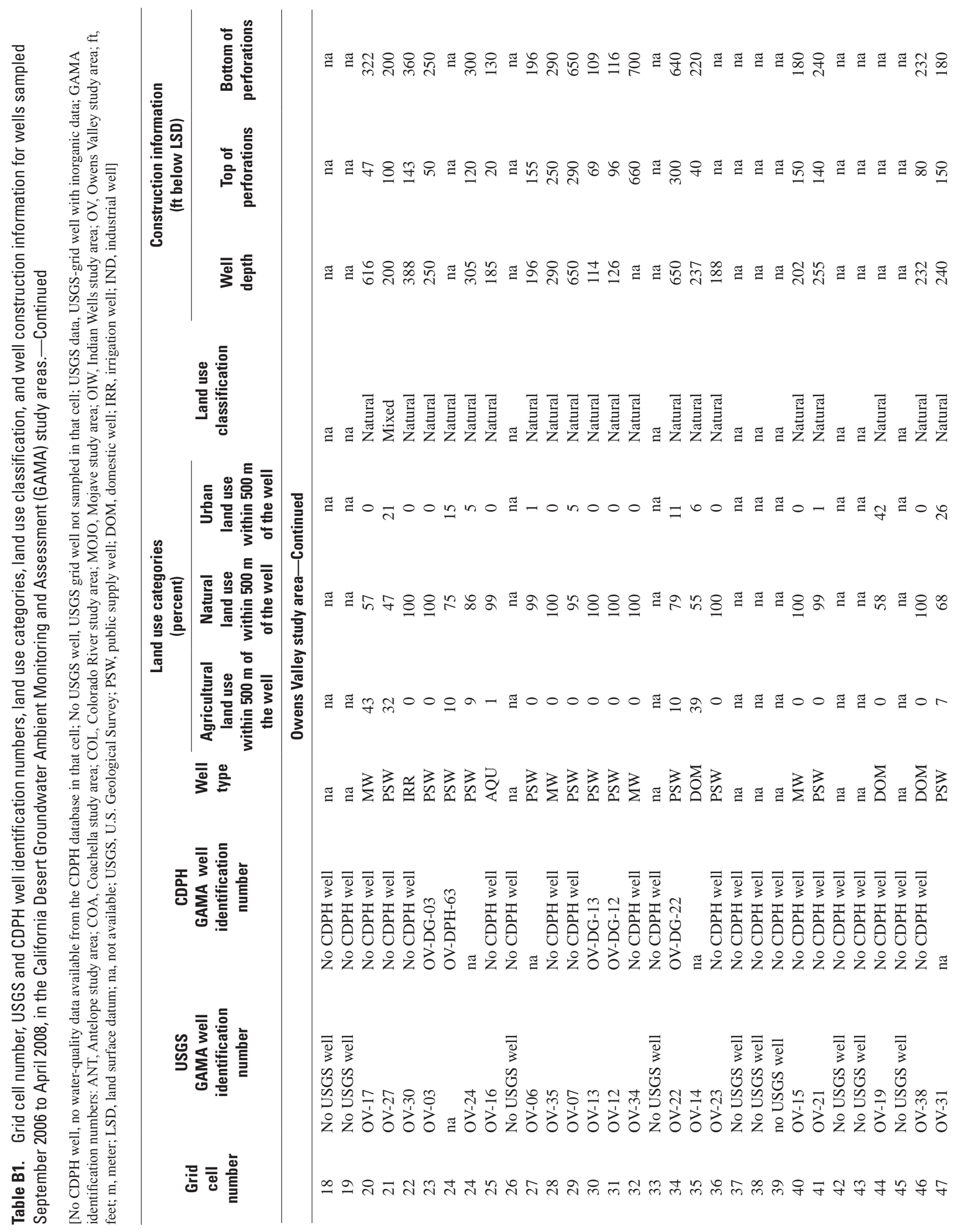




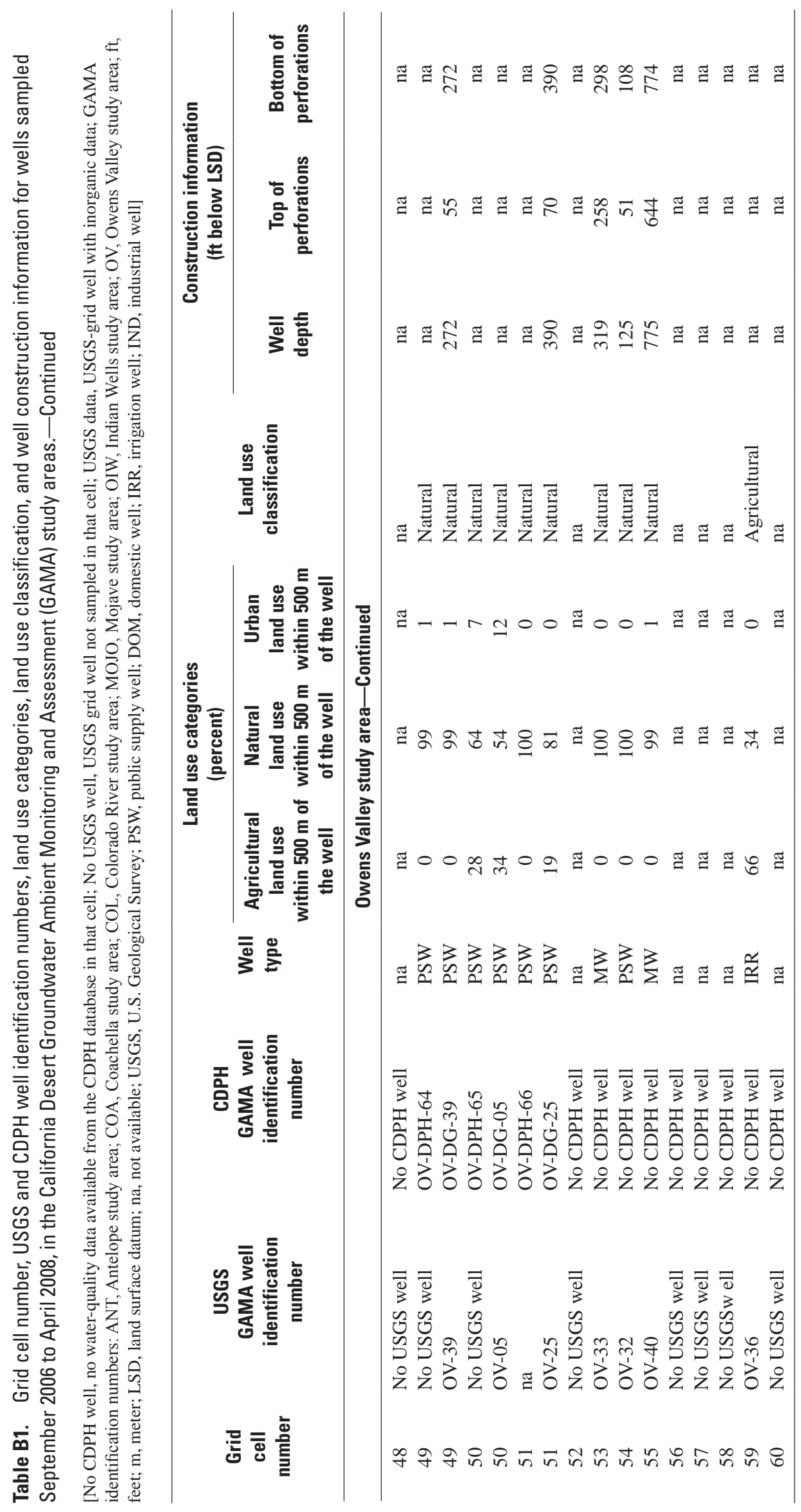



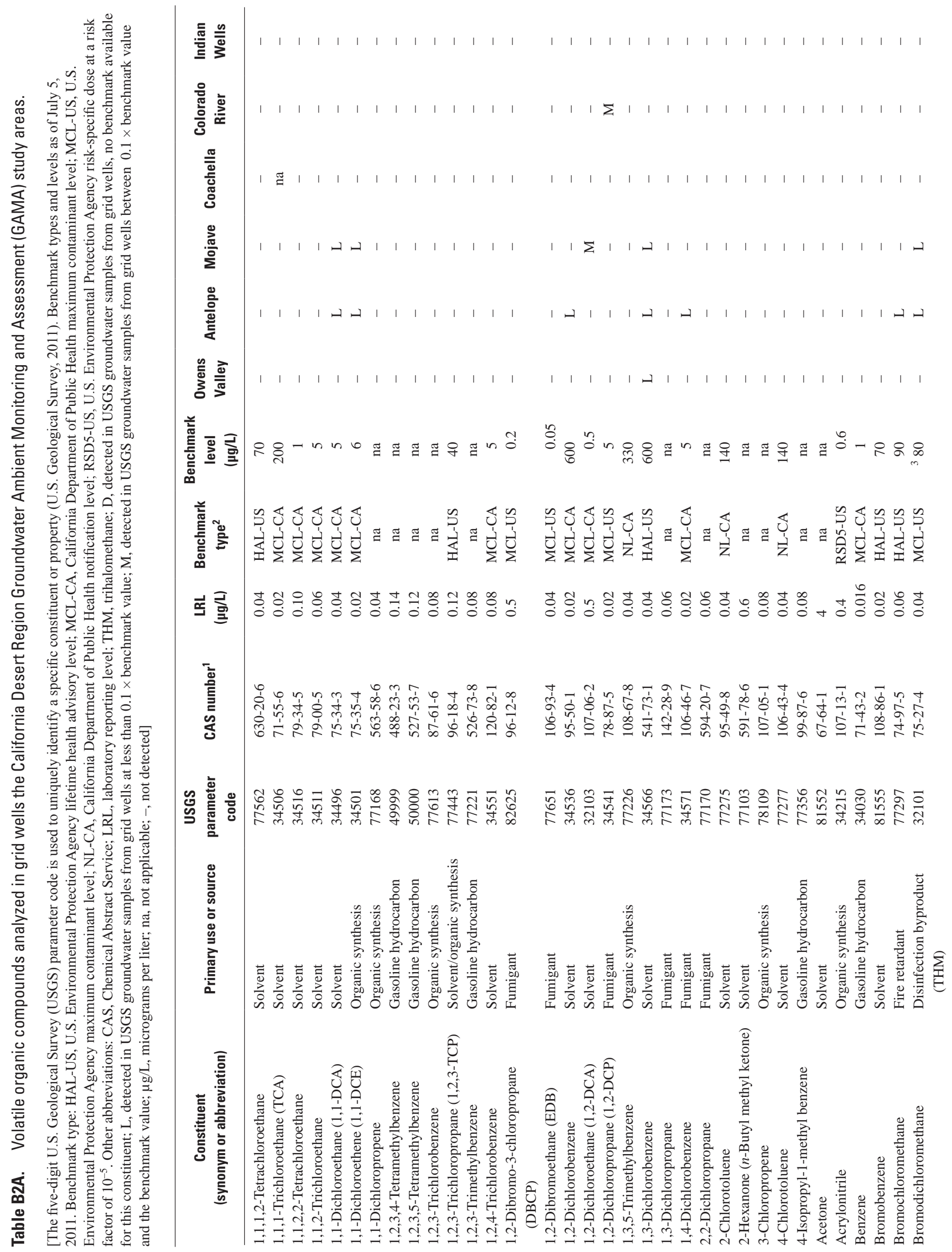


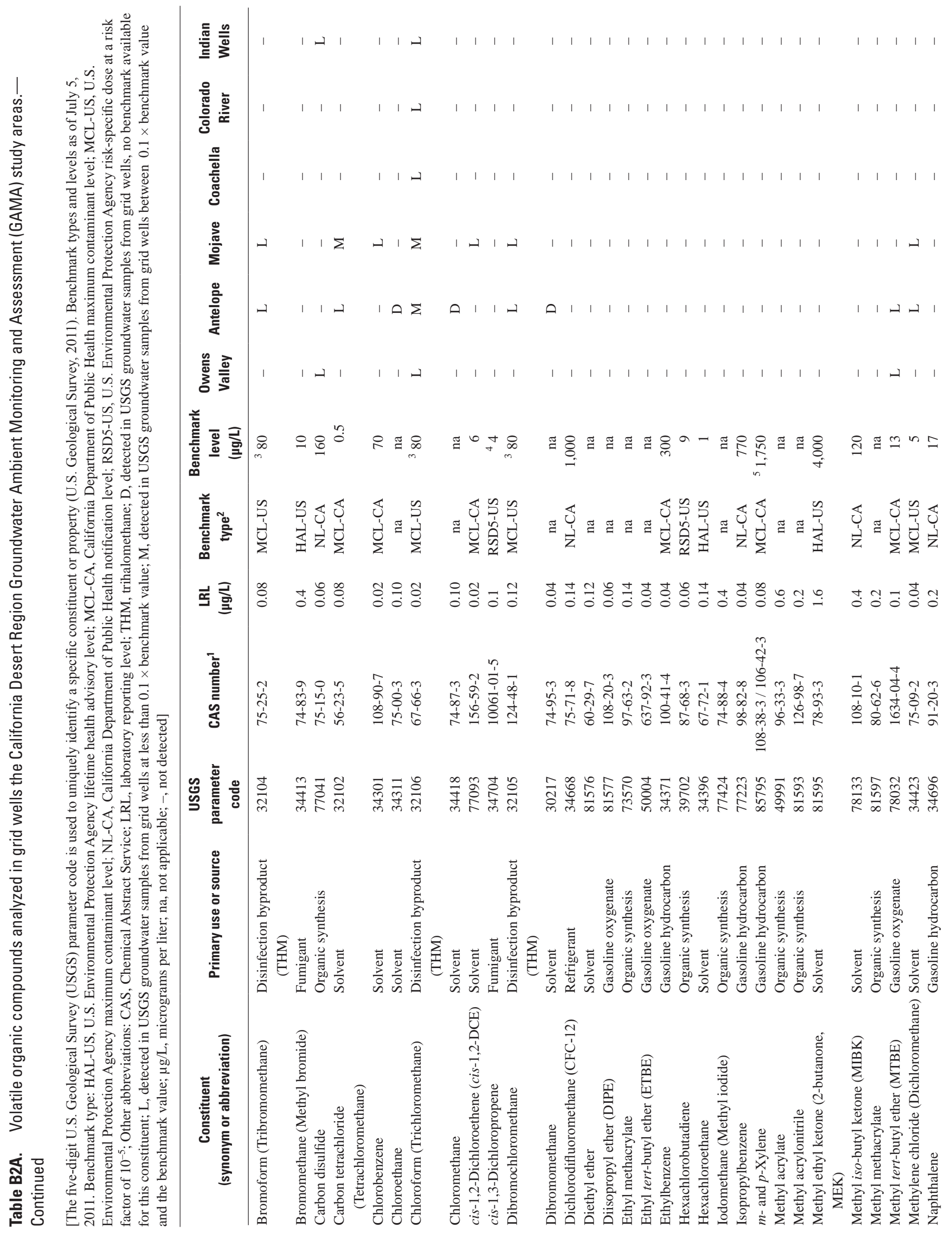



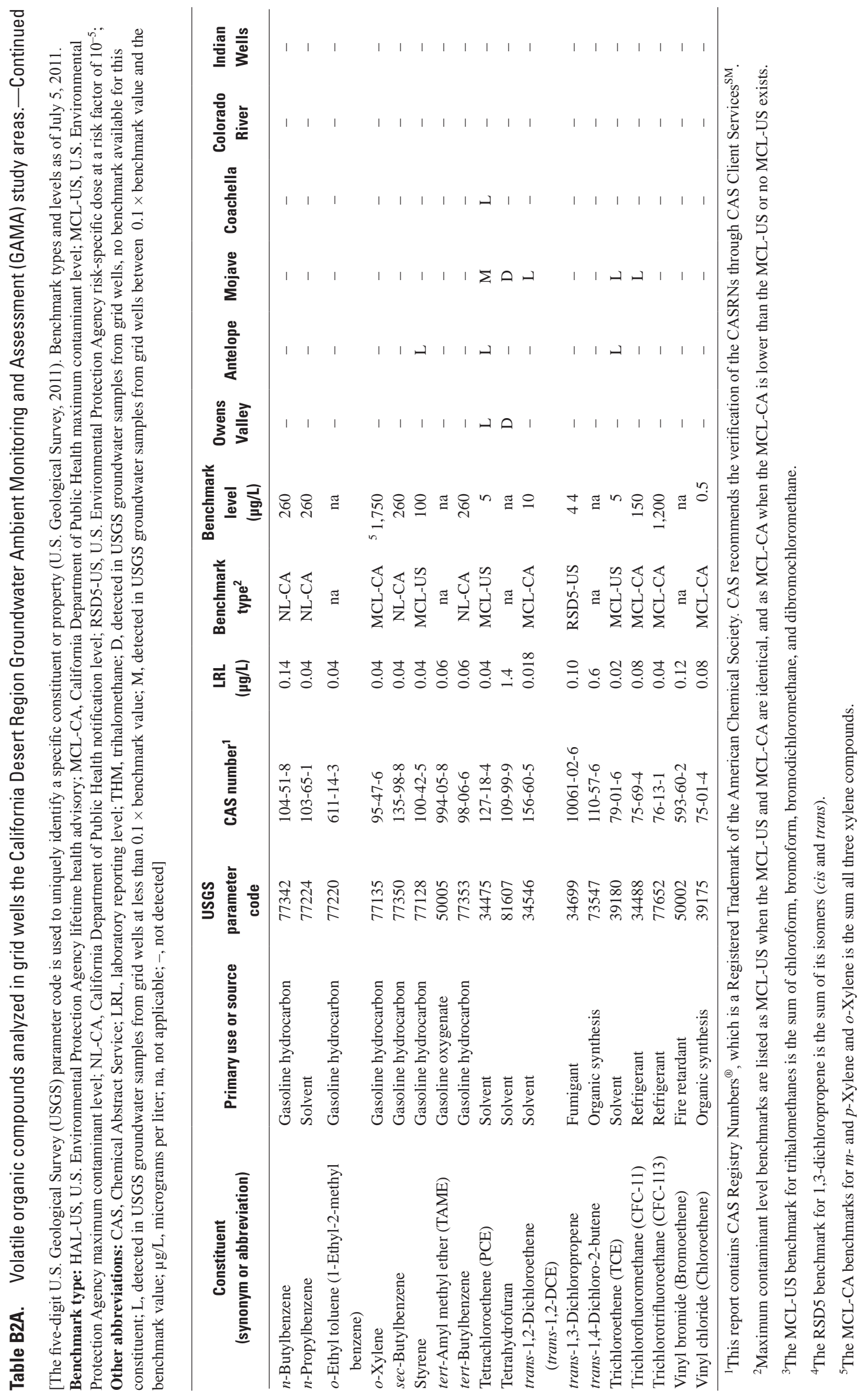

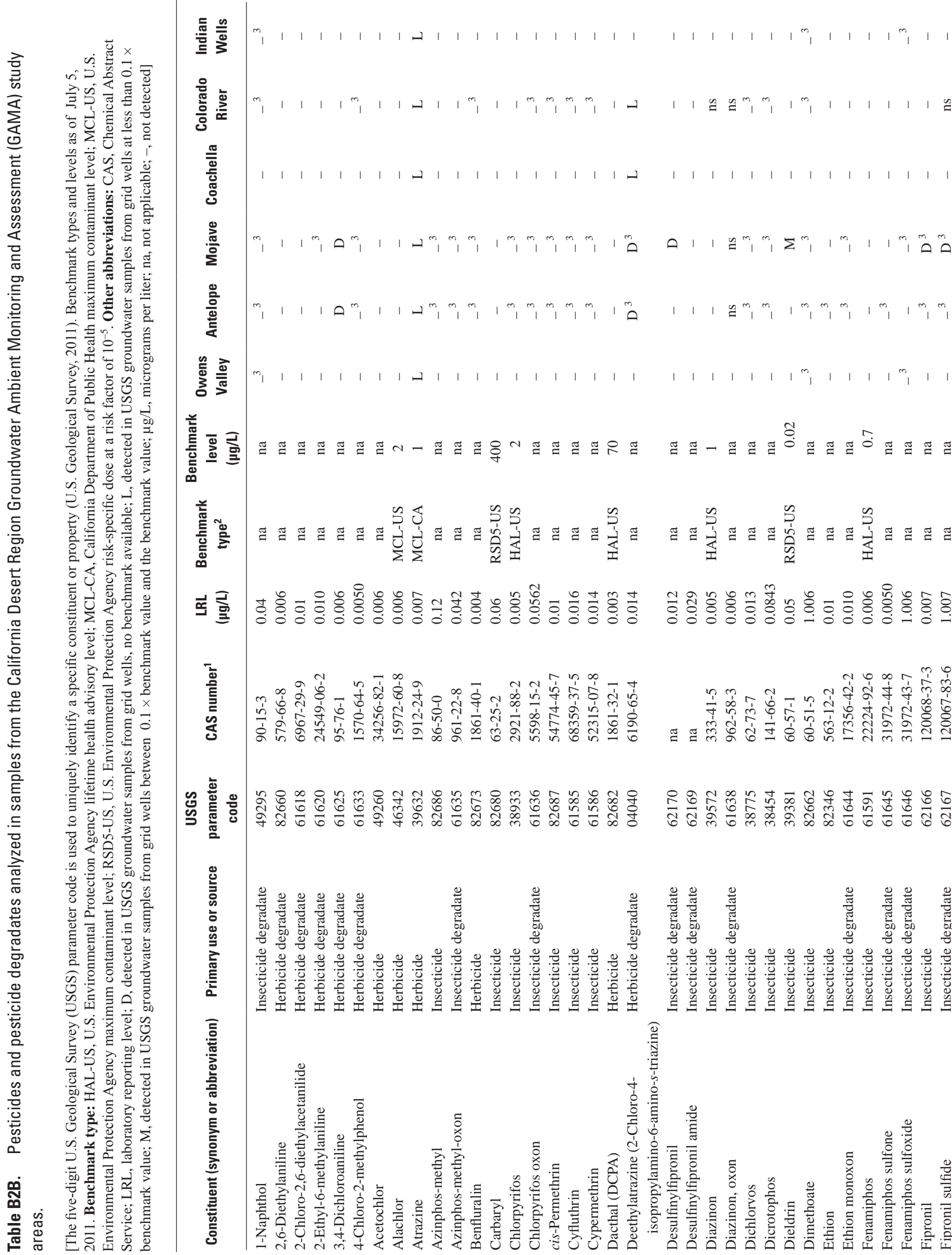

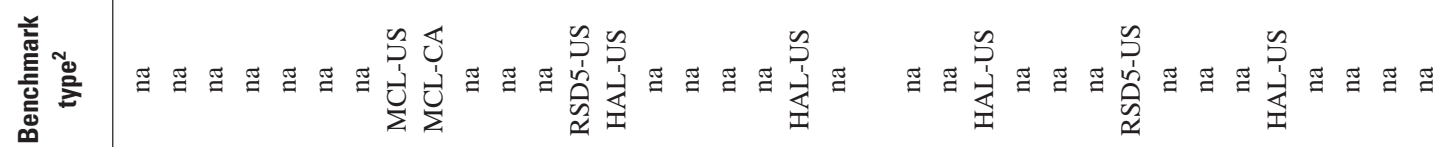

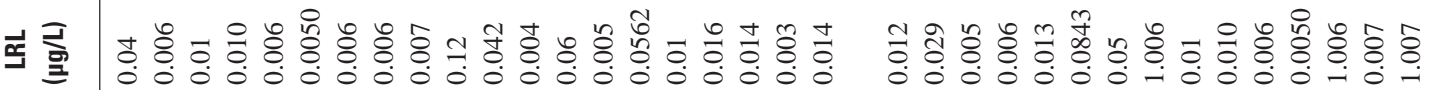

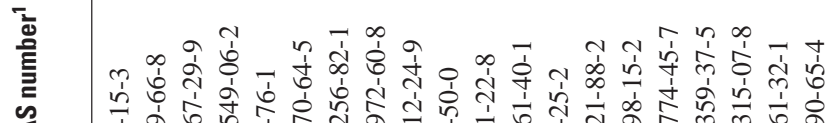

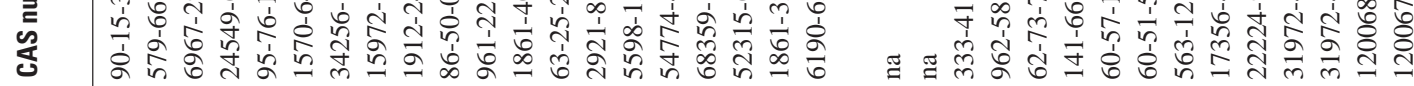

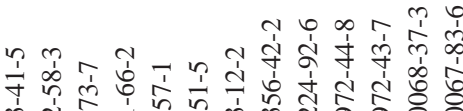

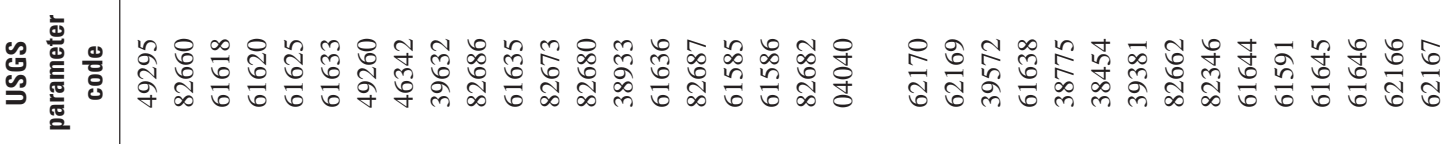

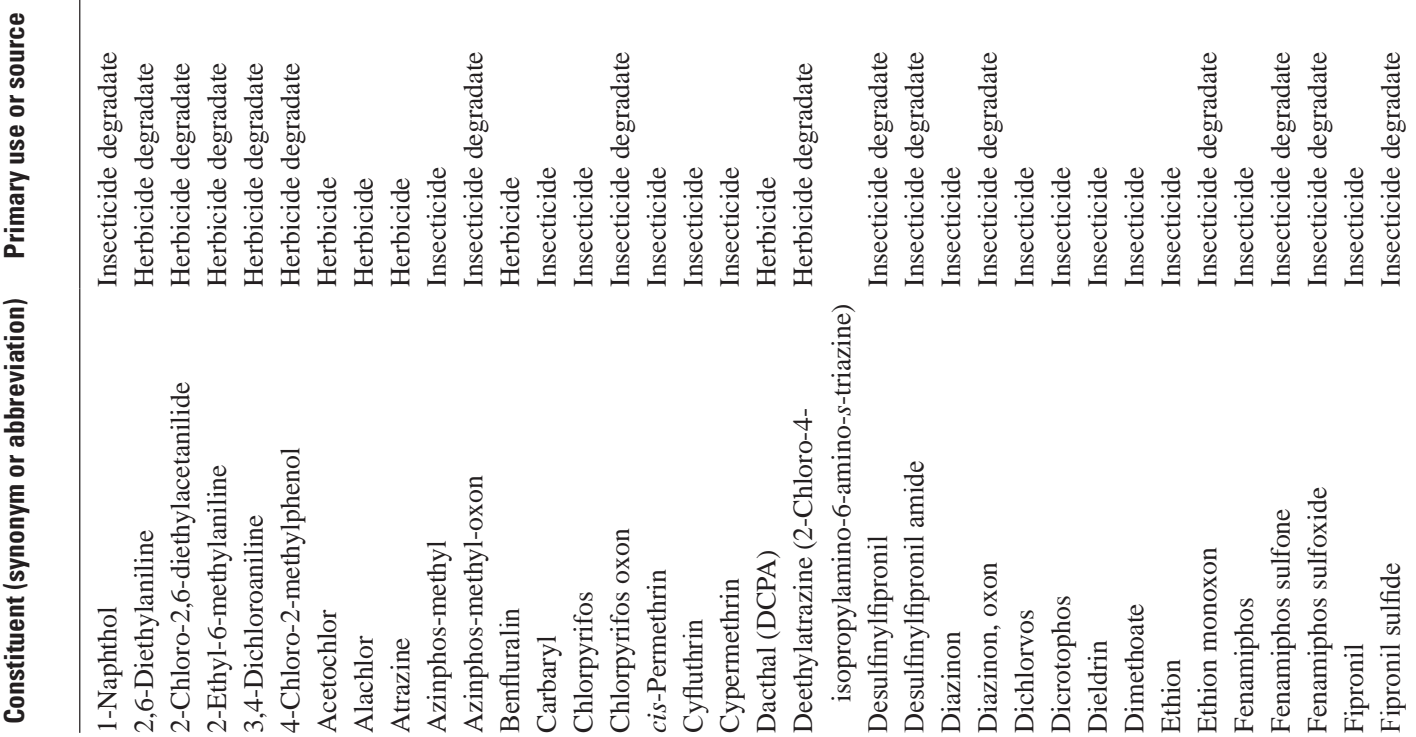




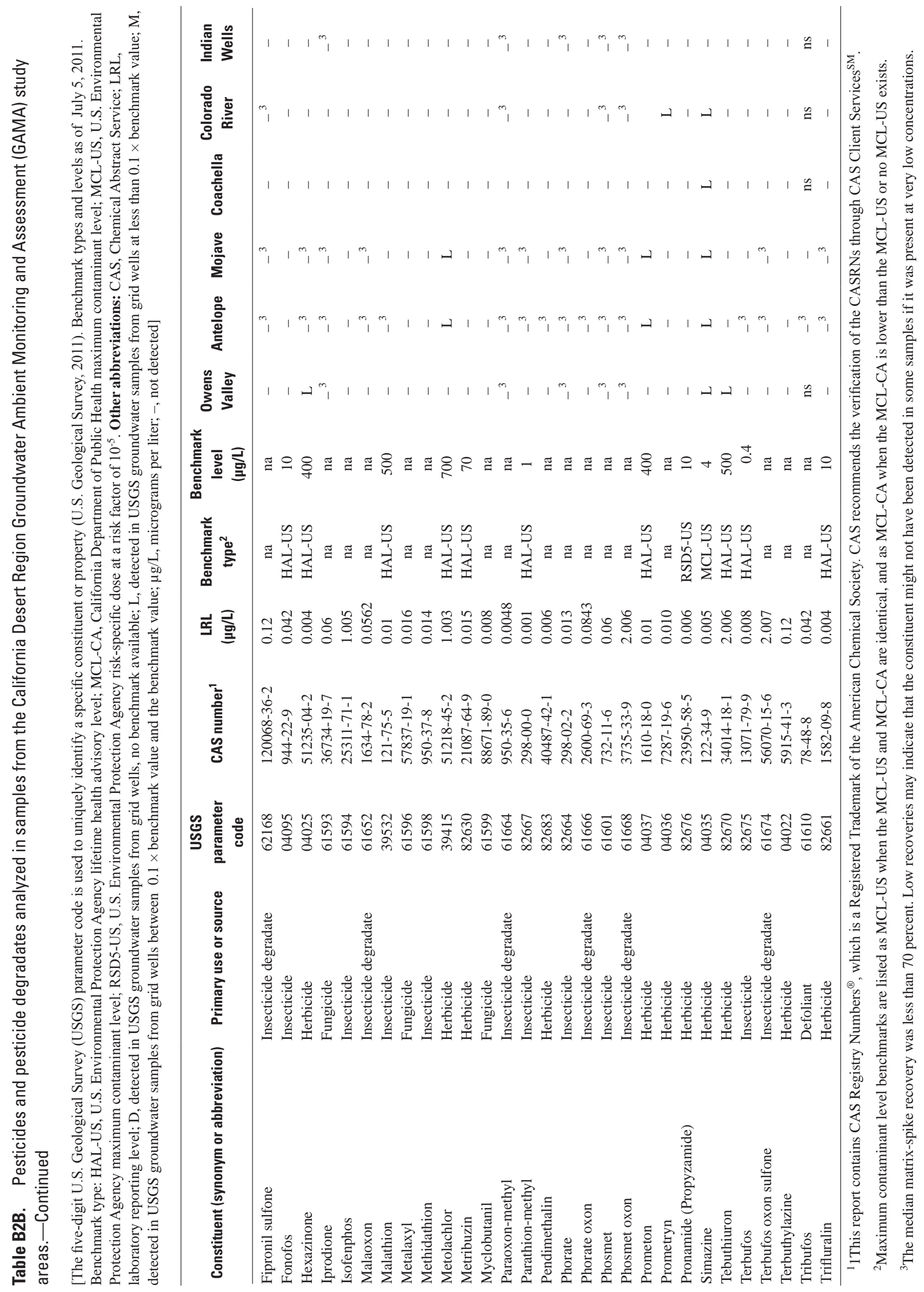




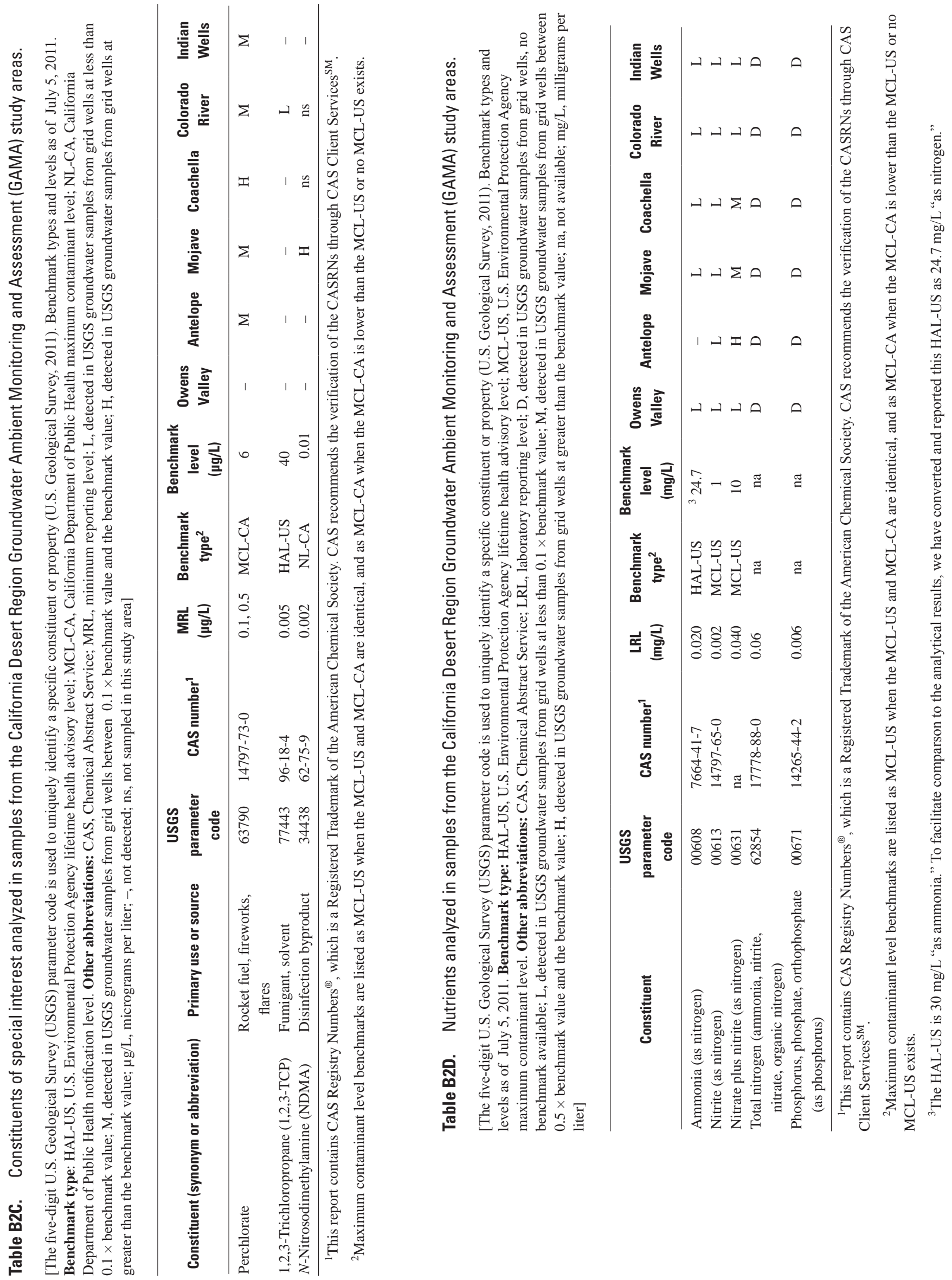



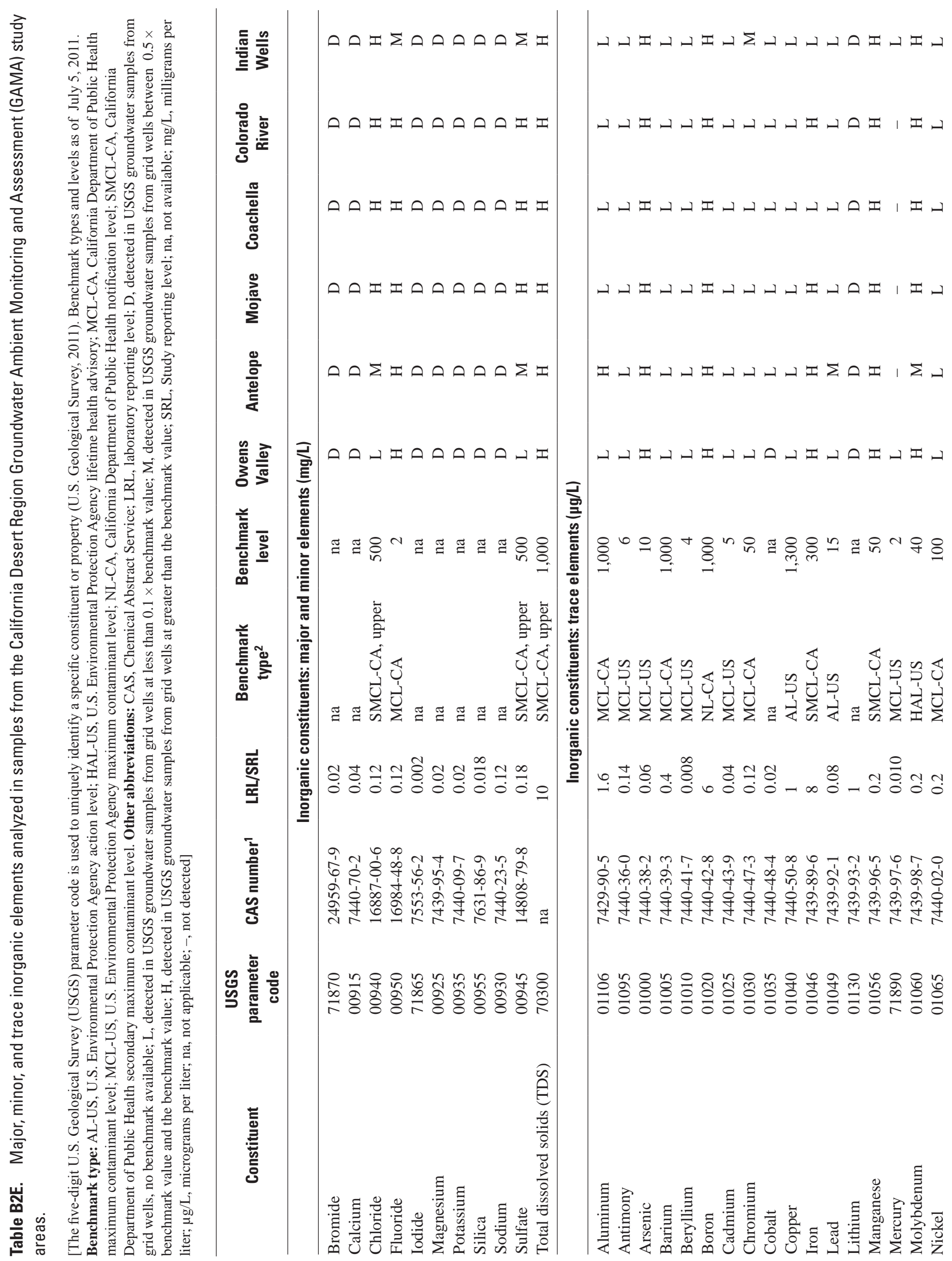


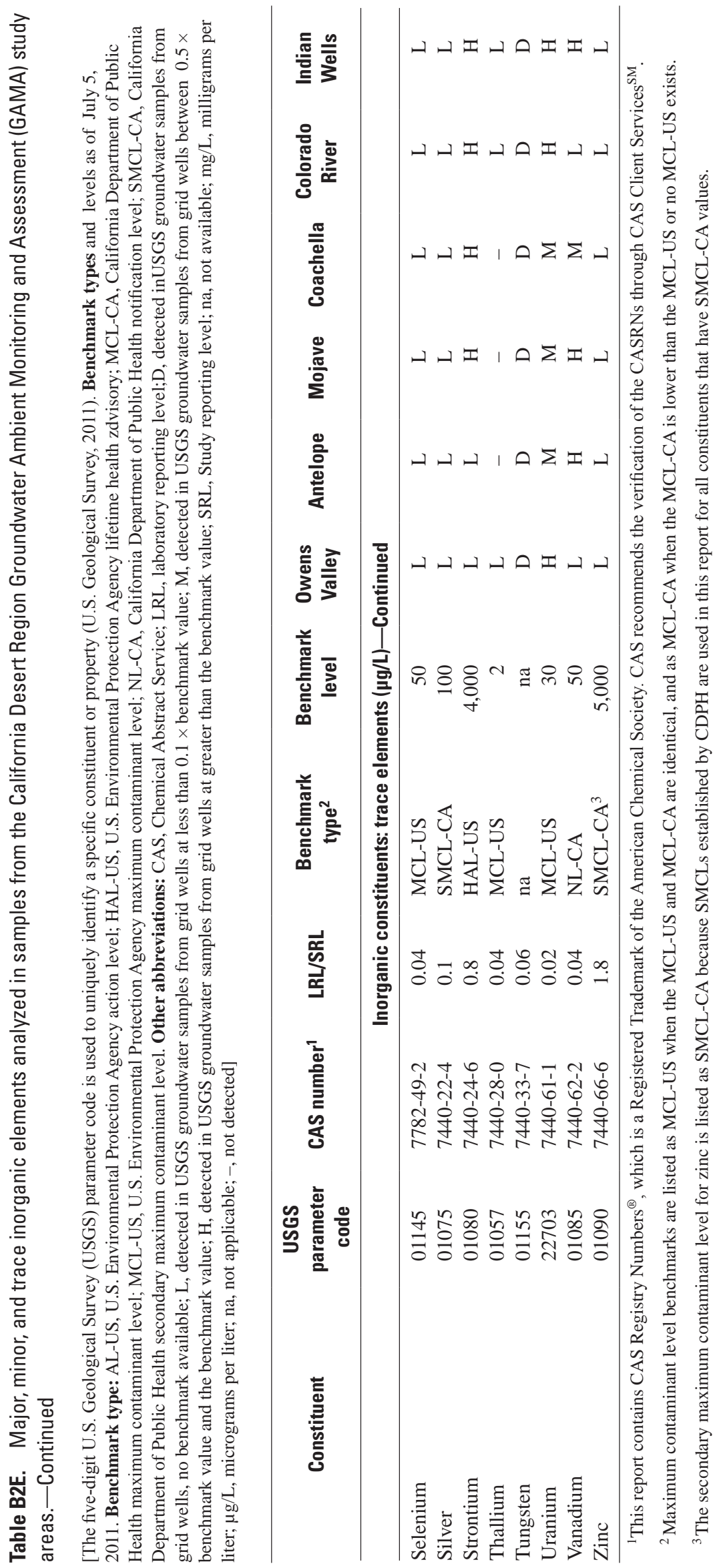




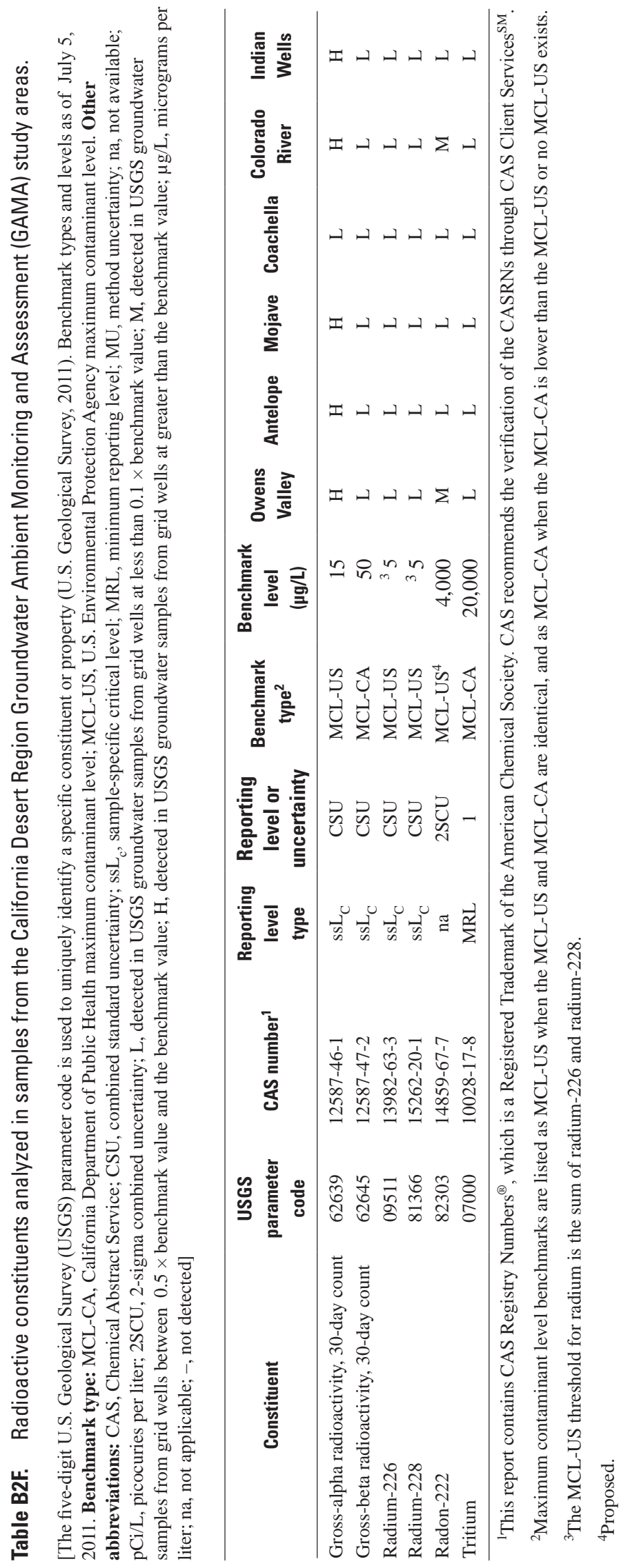




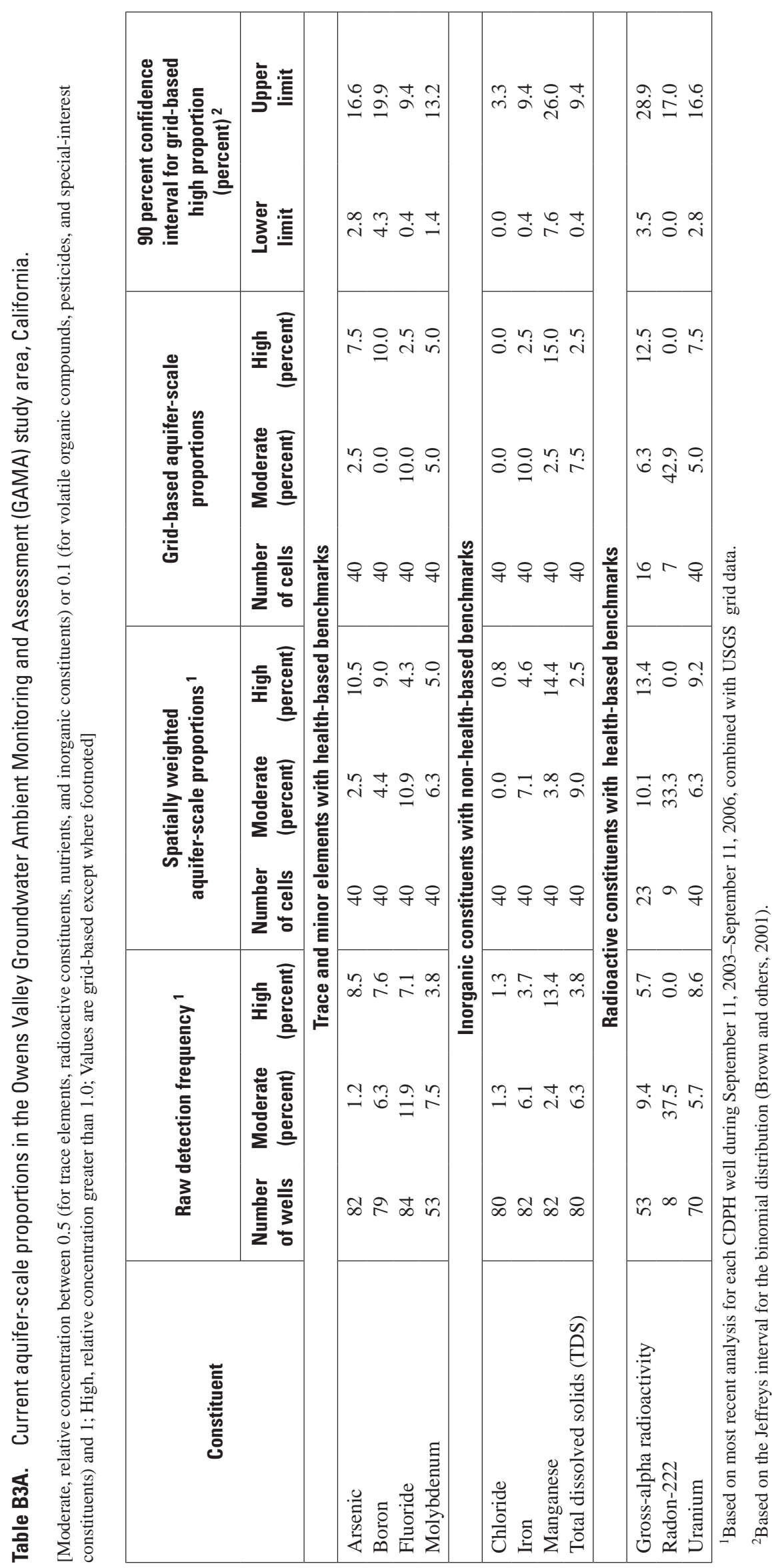




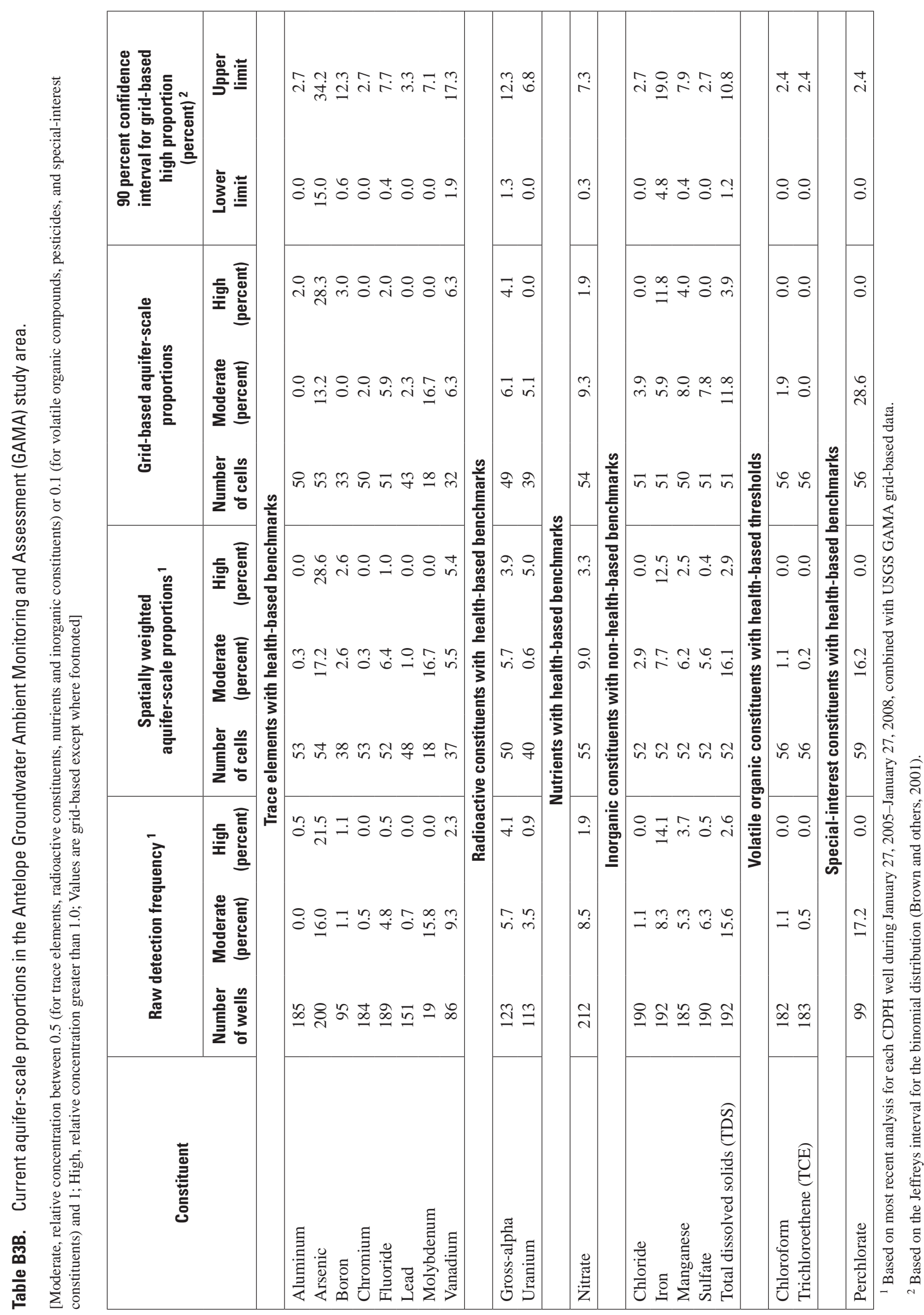




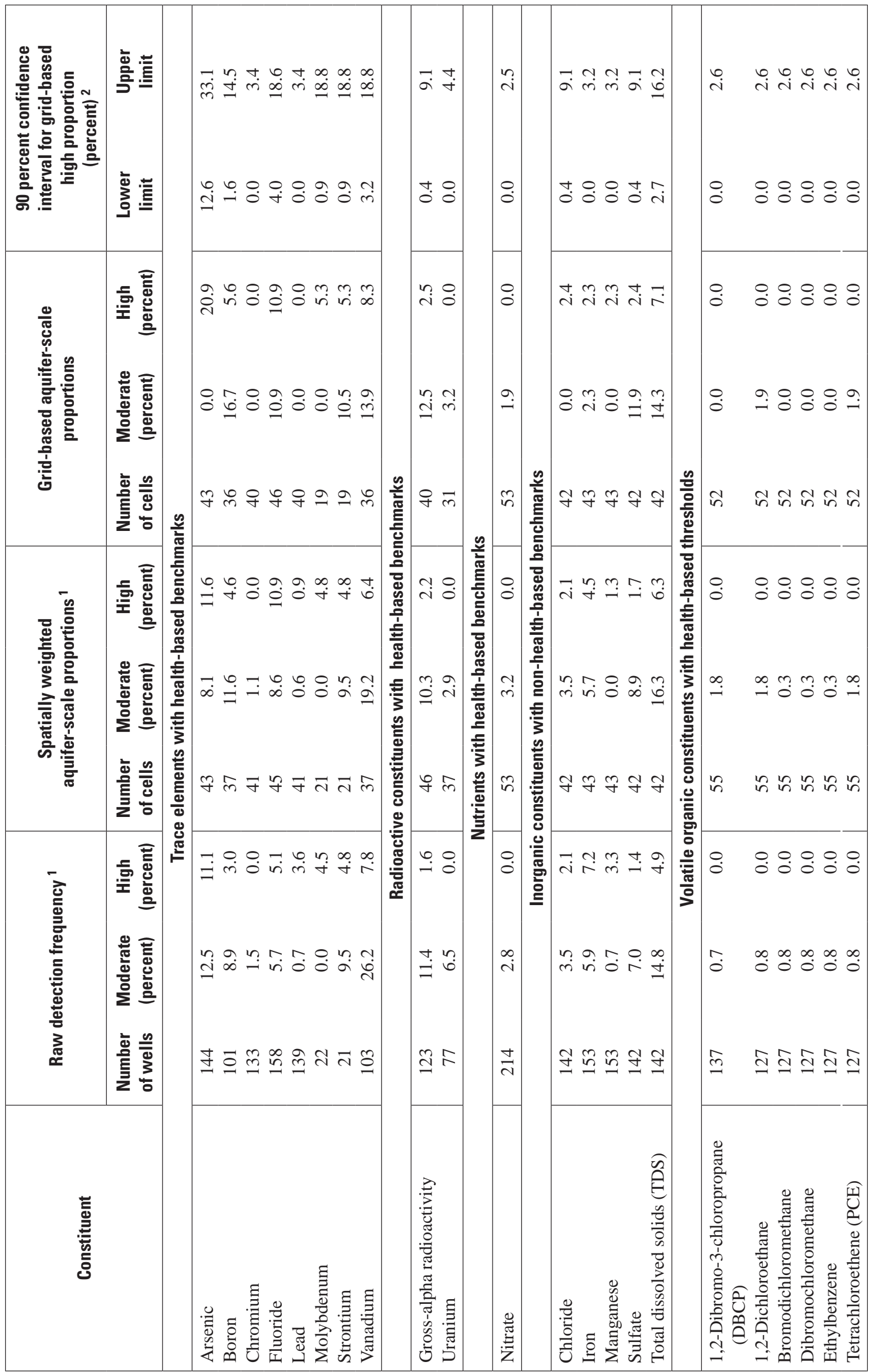




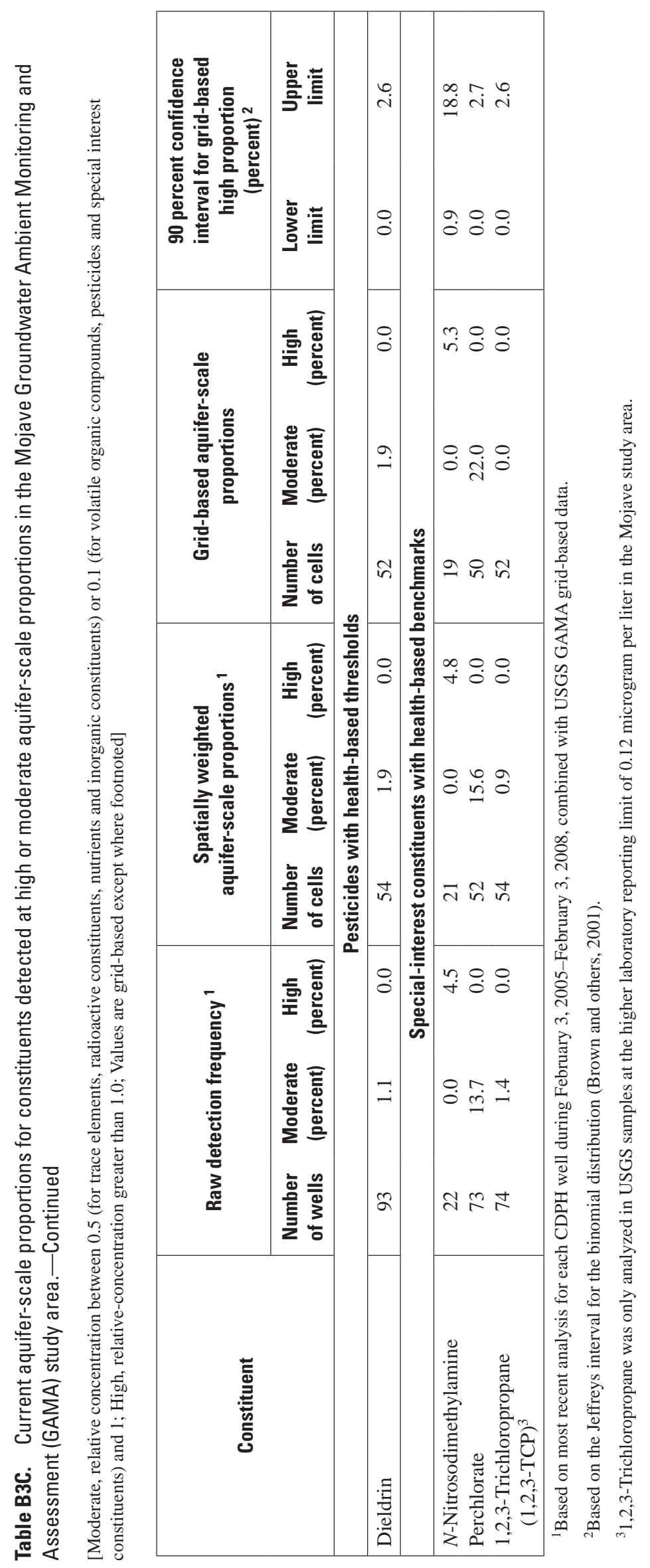




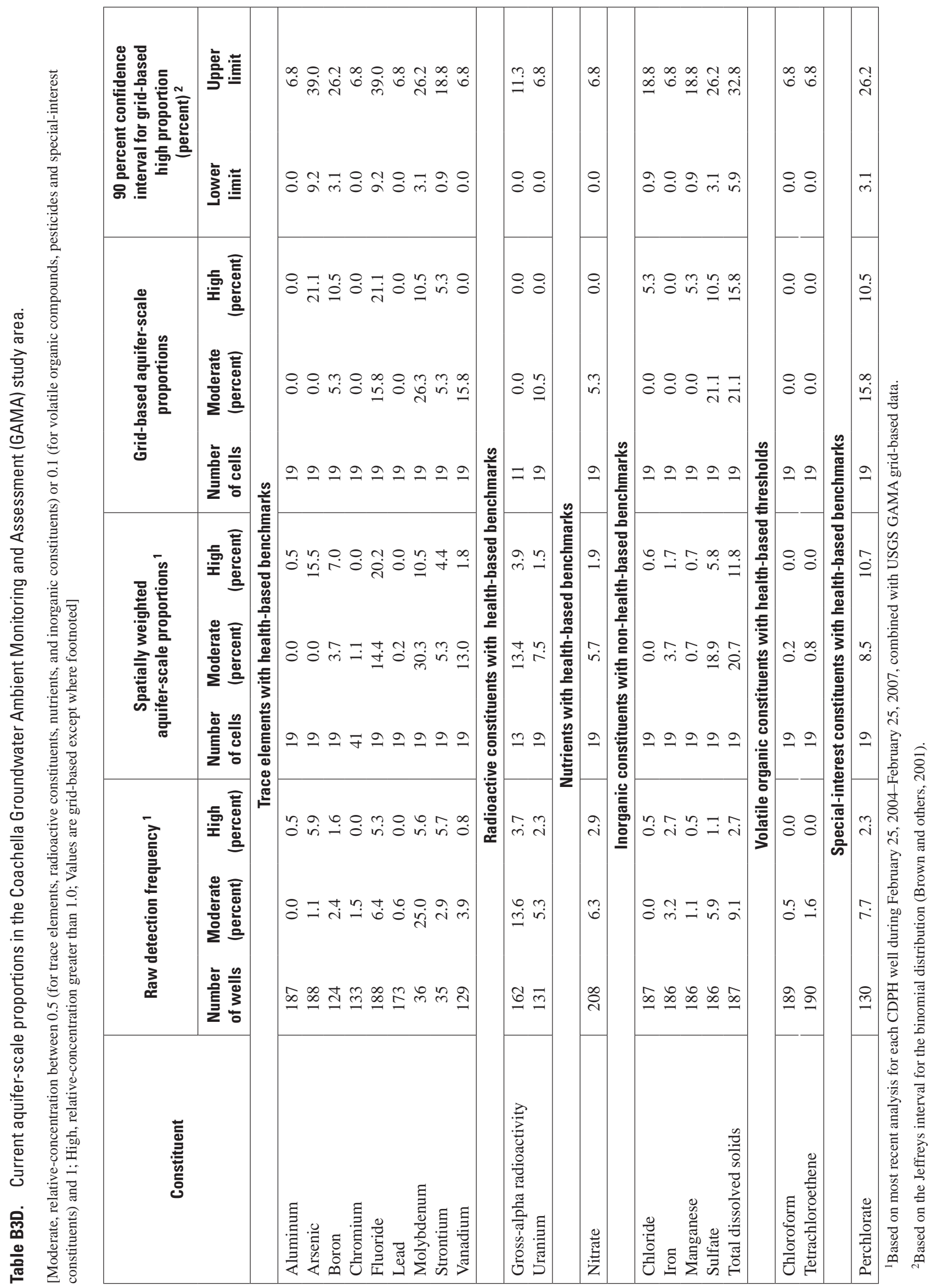




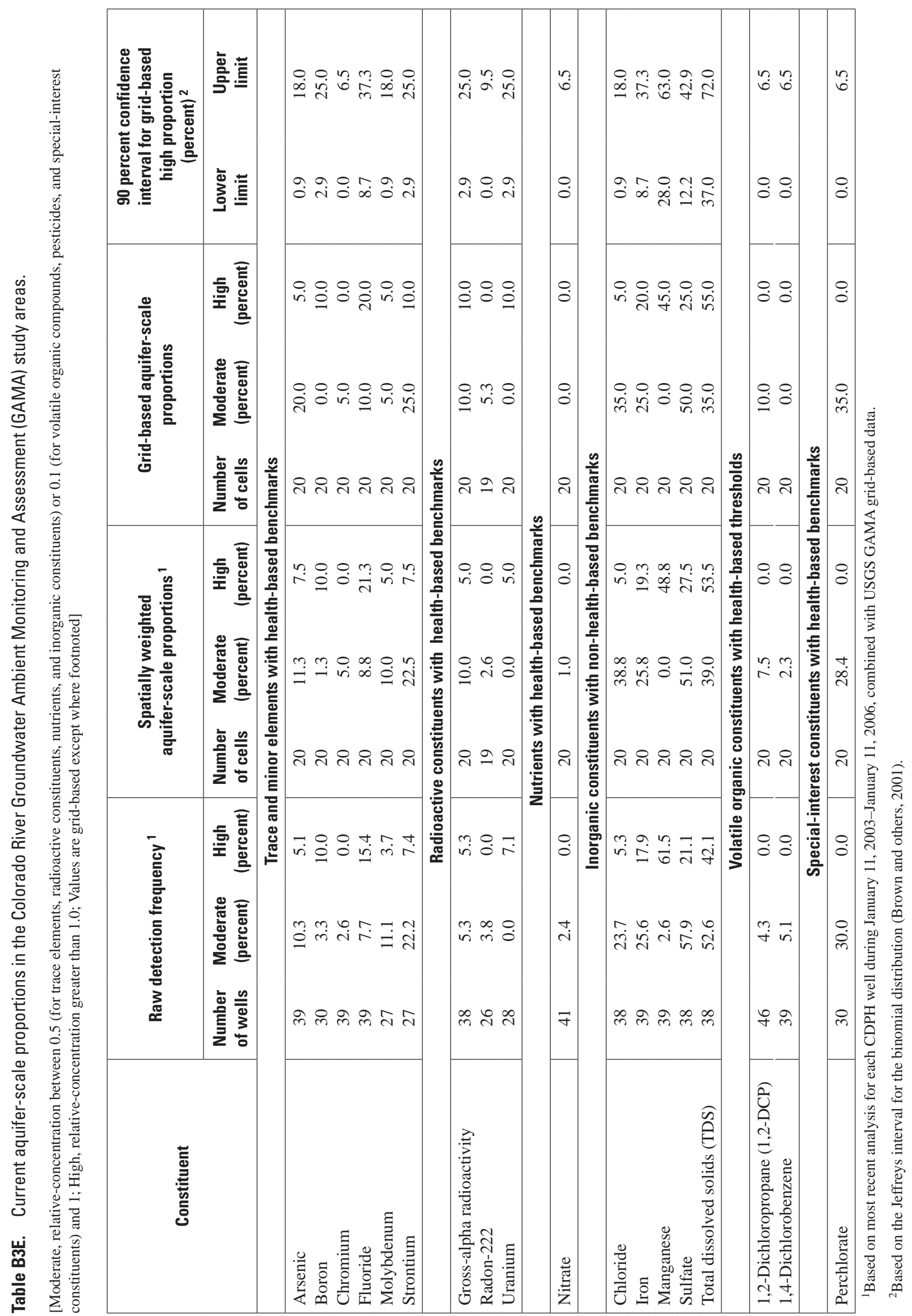




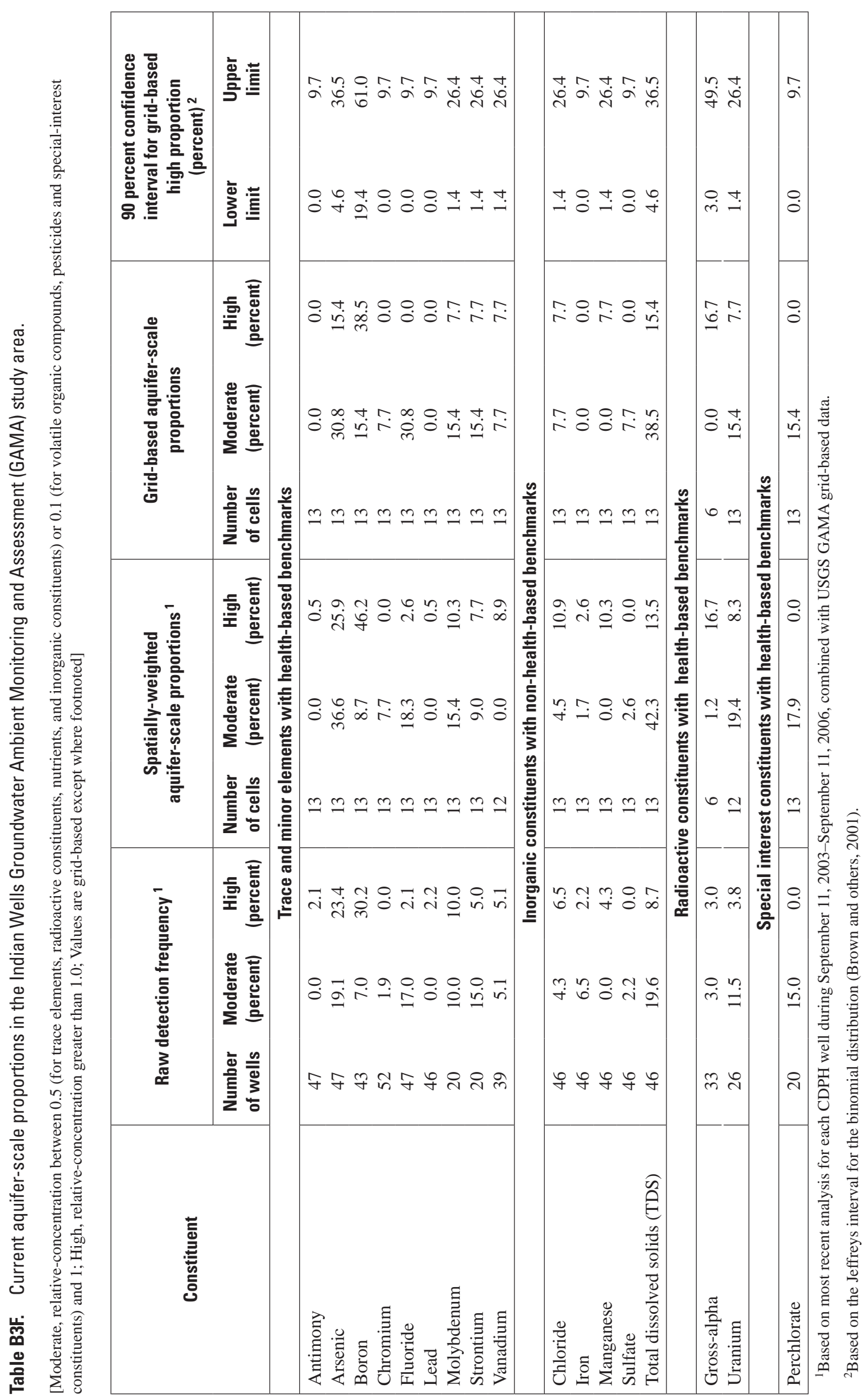




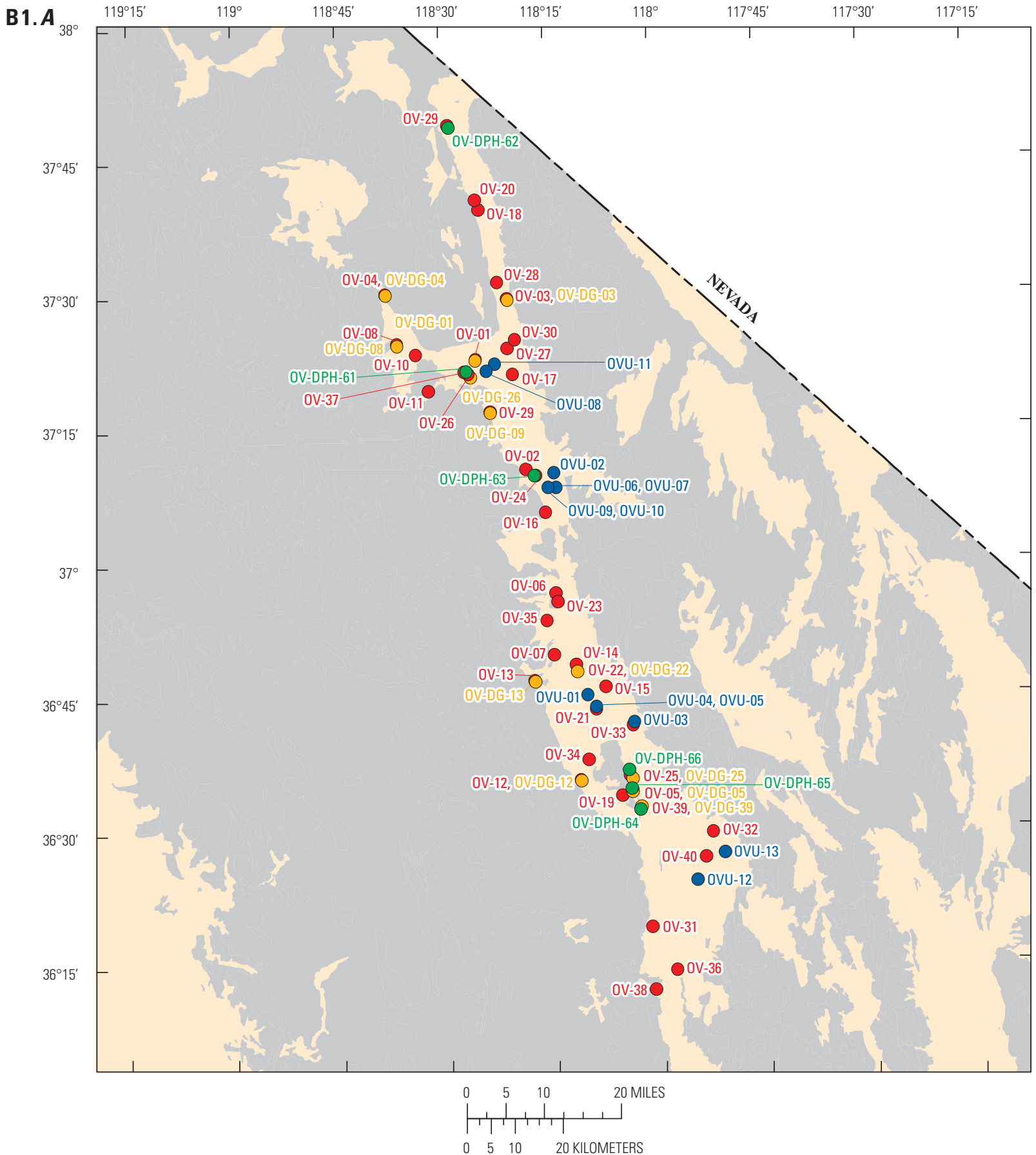

EXPLANATION

\begin{tabular}{lrll} 
Alluvium & \multicolumn{2}{c}{ Grid Data Points } \\
Hard Rock & OV-31 & $\bigcirc$ & USGS Data \\
& OV-12, OV-DG-12 & $\bigcirc$ & USGS and CDPH Data \\
& OV-DPH-64 & $\bigcirc$ & CDPH Data
\end{tabular}

Figure B1. Maps showing the locations and identification numbers of data points in the California Desert Region Groundwater Ambient Monitoring and Assessment (GAMA) study areas, 2006-2008: (A) Owens Valley, $(B)$ Antelope Valley, $(C)$ Mojave, $(D)$ Coachella Valley, $(E)$ Colorado River, and $(F$ Indian Wells Valley. 


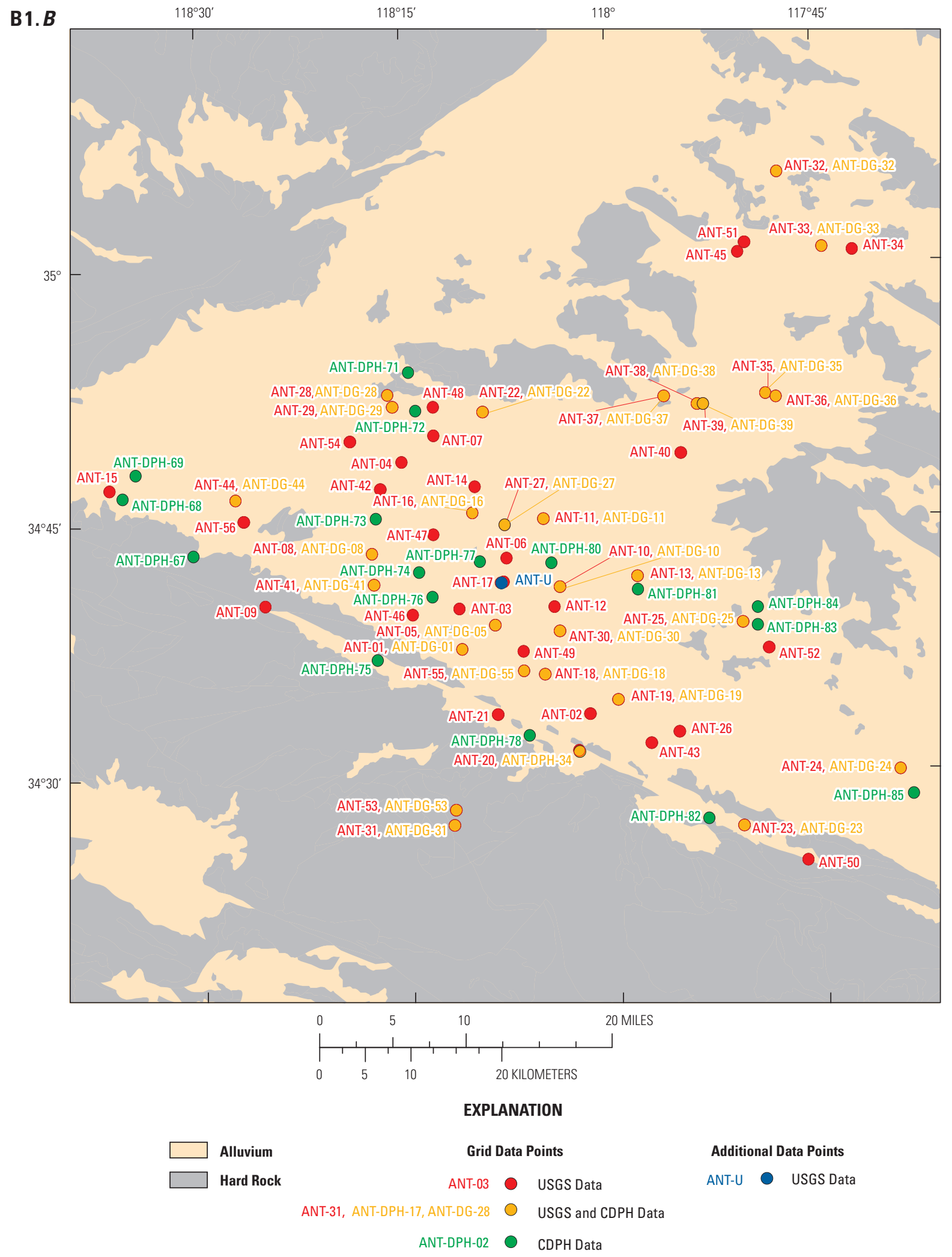

Figure B1.-Continued 
B1.C $117^{\circ} 30^{\prime}-117^{\circ} 15^{\circ}$

$117^{\circ}$ $116^{\circ} 45^{\prime}$

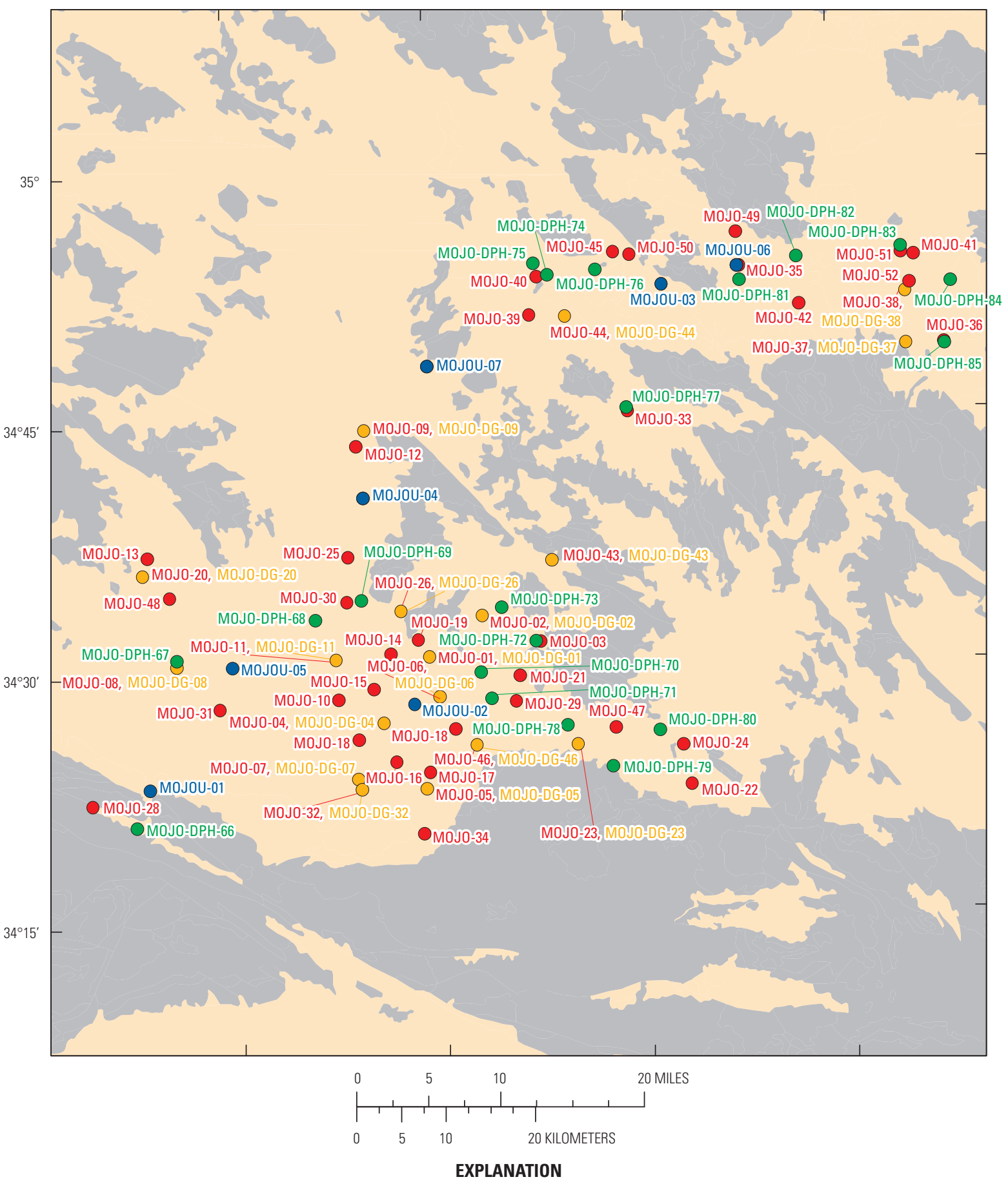

Alluvium

Hard Rock
Grid Data Points

MOJ0-03

MOJO-23, MOJO-DG-23

MOJO-DPH-66
Additional Data Points

MOJOU-02

USGS Data

USGS and CDPH Data

CDPH Data

Figure B1.-Continued 


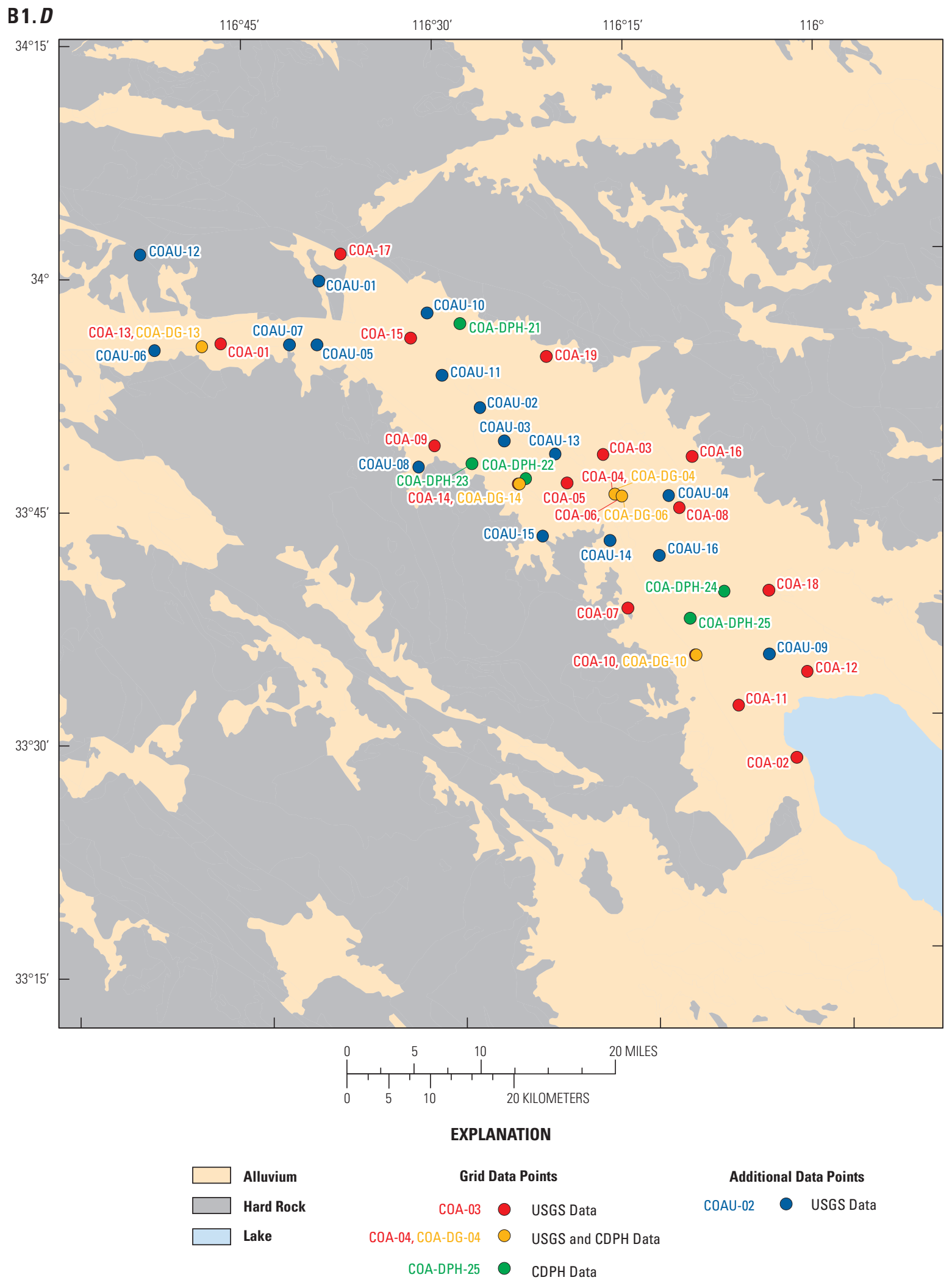

Figure B1.-Continued 


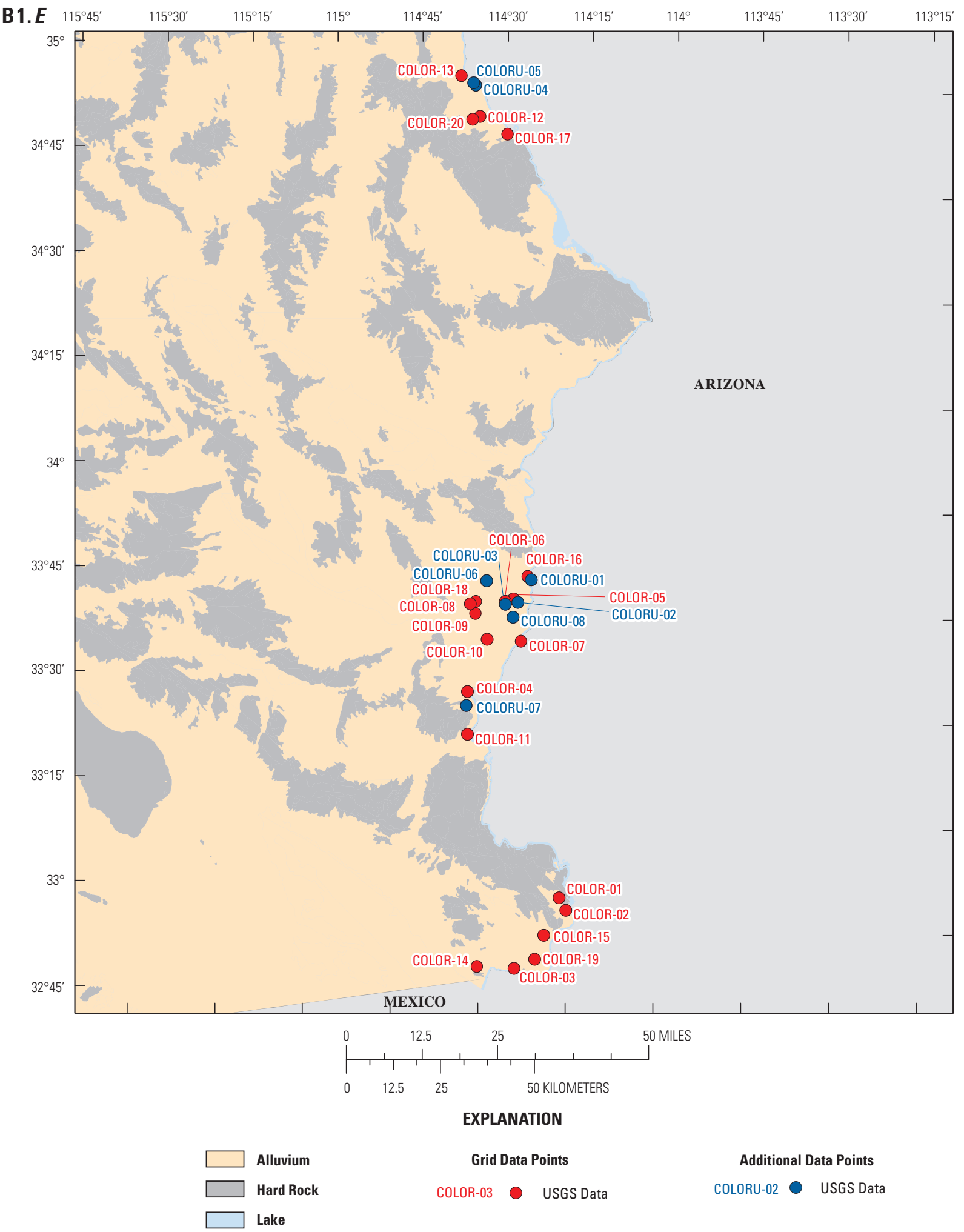

Figure B1.-Continued 


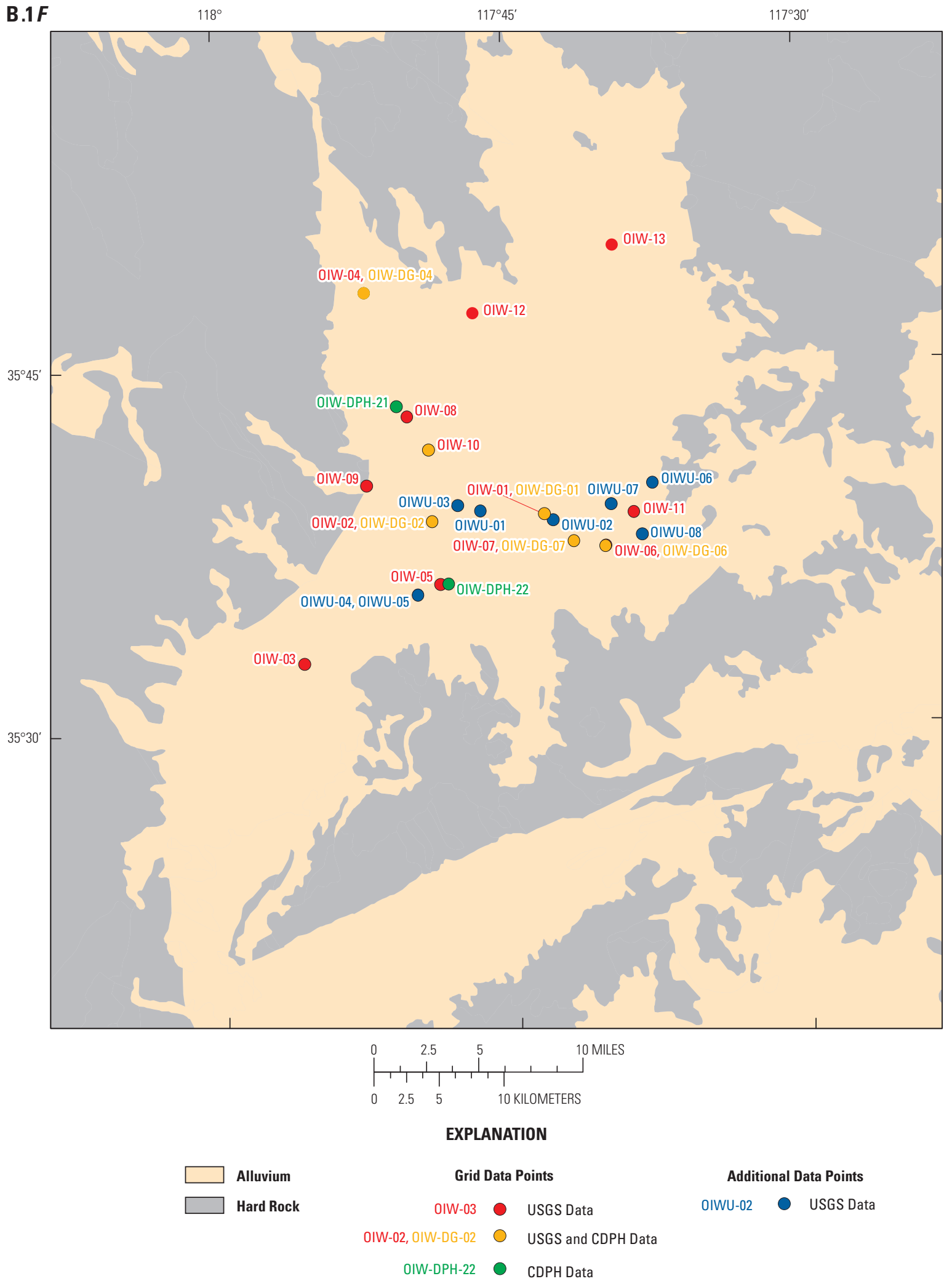

Figure B1.-Continued 

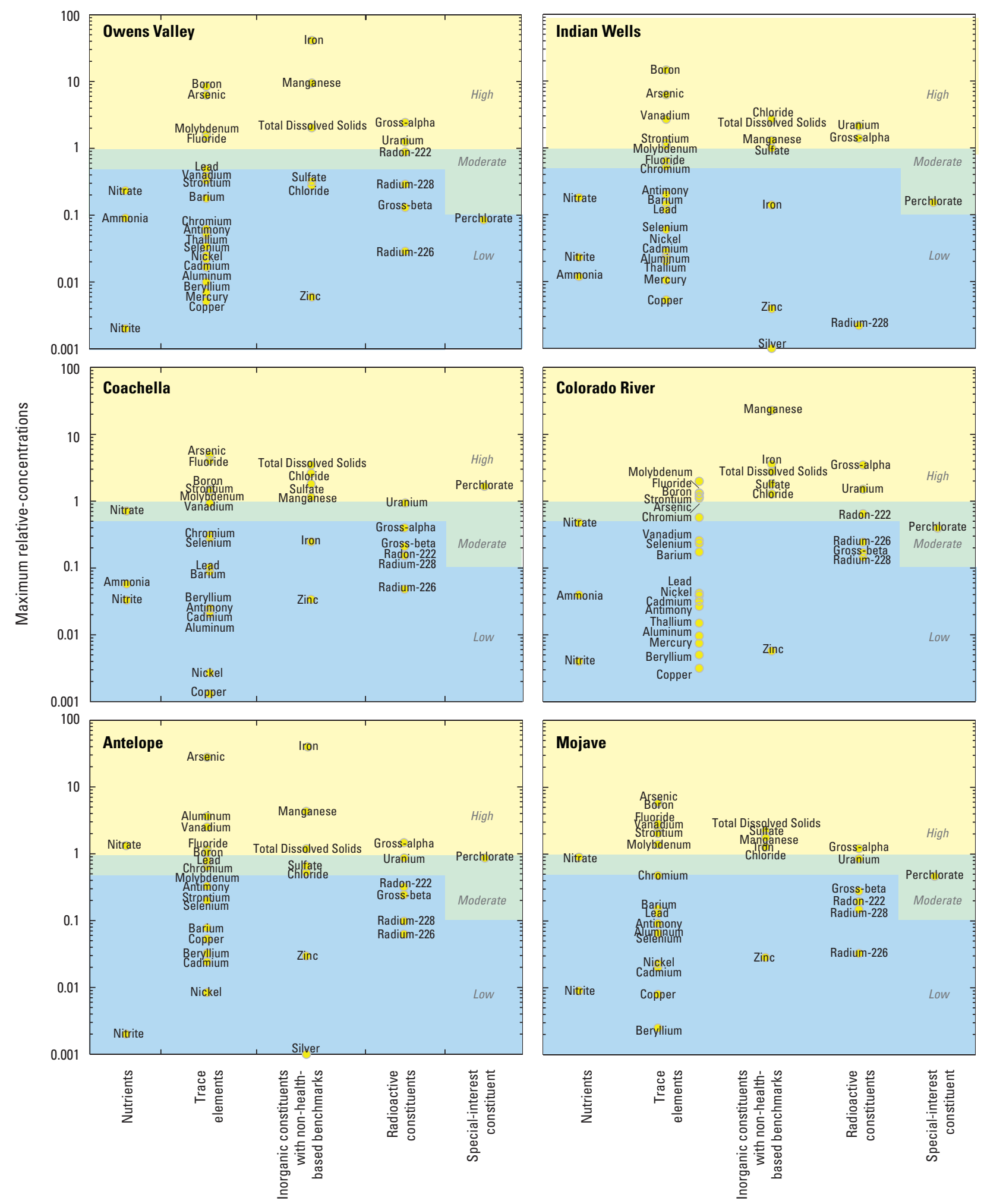

Figure B2. Graphs showing the maximum relative-concentrations of inorganic constituents with health-based or non-health-based benchmarks detected in grid wells by constituent class in the California Desert Region Groundwater Ambient Monitoring and Assessment (GAMA) study areas, 2006-2008. 

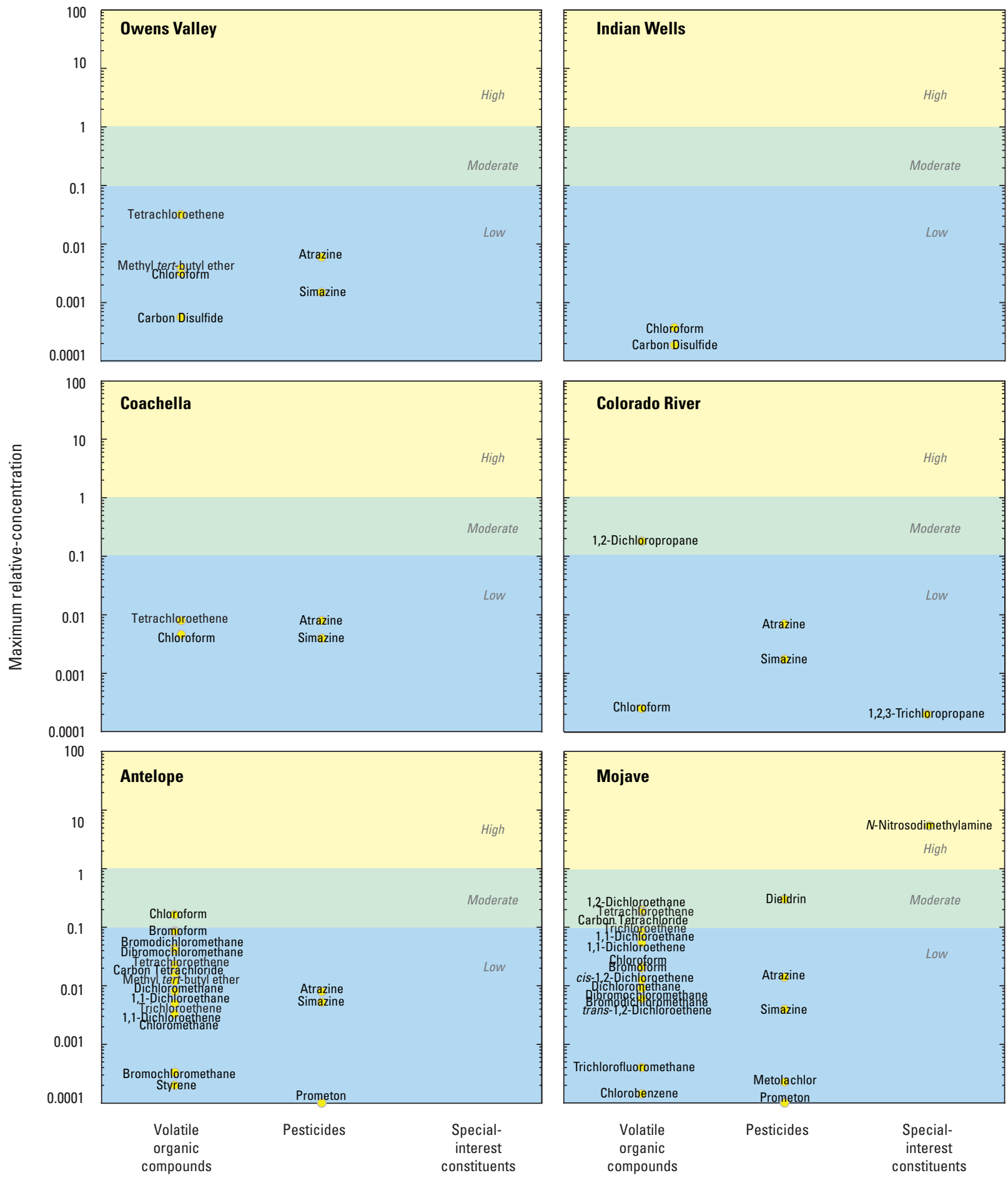

Figure B3. Graphs showing the maximum relative-concentrations of organic constituents with healthbased benchmarks detected in grid wells by constituent class in the California Desert Region Groundwater Ambient Monitoring and Assessment (GAMA) study areas, 2006-2008. 

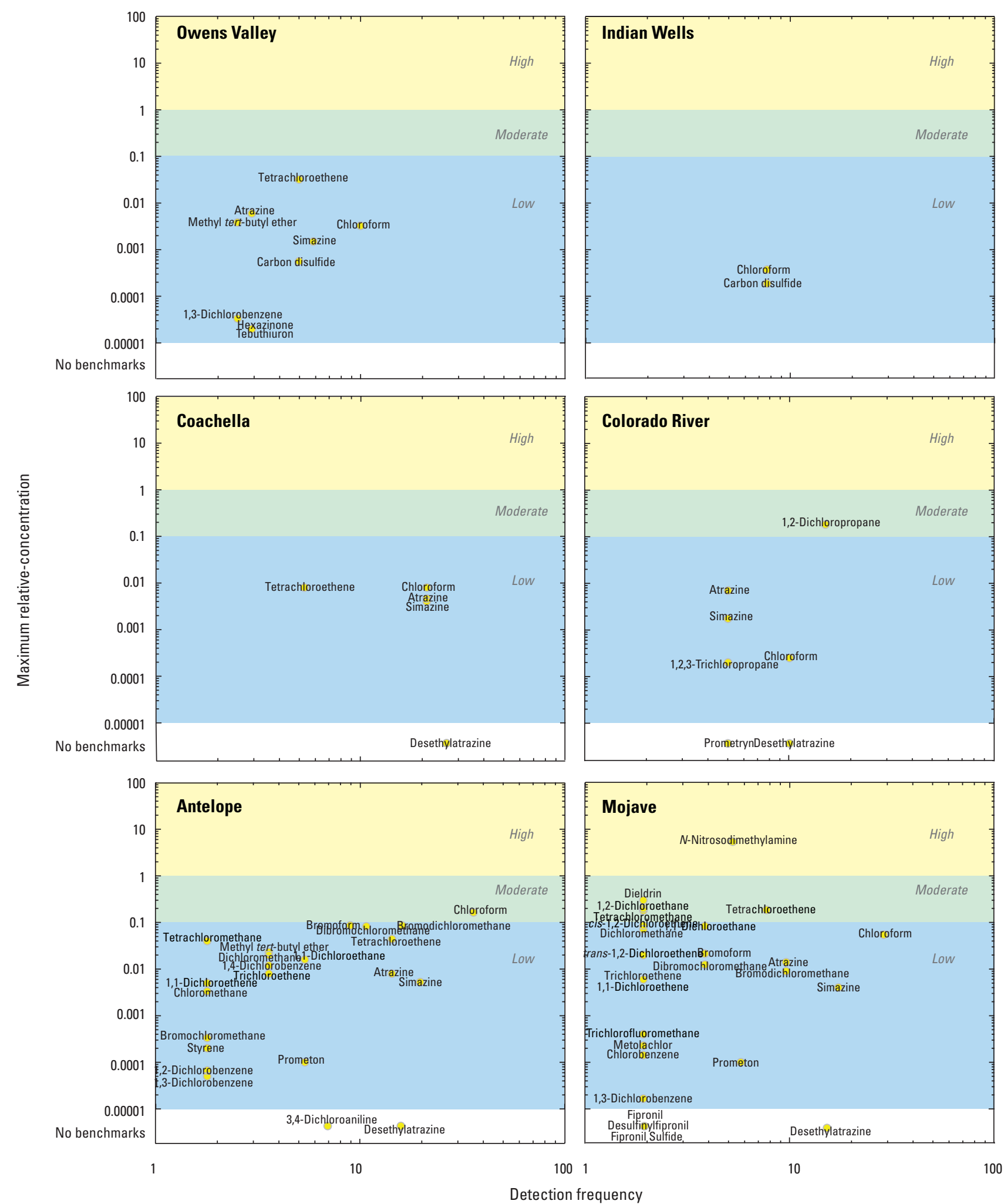

Figure B4. Graphs showing the detection frequencies and maximum relative-concentrations of organic constituents detected in grid wells in the California Desert Region Groundwater Ambient Monitoring and Assessment (GAMA) study areas, 2006-2008. 


\section{Appendix C. Comparison of CDPH and USGS-GAMA Data}

Comparisons of CDPH and USGS-GAMA data were done to assess the validity of using data from these different sources in combination. Concentrations of inorganic constituents (alkalinity, fluoride, magnesium, potassium, sodium, sulfate, and total dissolved solids), which generally are prevalent at concentrations substantially above laboratory reporting levels, were compared for each well with data from both sources. Sixty wells had major-ion data from USGS and the CDPH databases. Although differences between the paired datasets occurred for a few wells, most sample pairs plotted close to a 1-to-1 line (fig. C1). Wilcoxon signed-rank tests of paired analyses of alkalinity, fluoride, magnesium, potassium, sodium, sulfate, and total dissolved solids yielded results of no significant differences $(p>0.05)$ between USGS and CDPH data for any of the constituents.
Major-ion data for Desert Region grid wells were plotted on Piper diagrams (Piper, 1944) with all CDPH major-ion data to determine if the grid wells represented the range of groundwater types that have historically been observed in the Desert Region. Piper diagrams show the relative abundance of major cations and anions (on a charge-equivalent basis) as a percentage of the total ion content of the water and are often used to define groundwater type (Hem, 1985). All CDPH data having cation/anion data and a cation/anion imbalance of less than 10 percent were retrieved and plotted on these Piper diagrams for comparison with grid-well data. A similar range of water types was evident from grid wells and historical $\mathrm{CDPH}$ data (fig. C2). This similarity of the range of relative abundance of major cations and anions in grid wells compared to the set of all CDPH wells indicates that the grid wells represent the types of water present within the Desert Region's primary aquifers. 


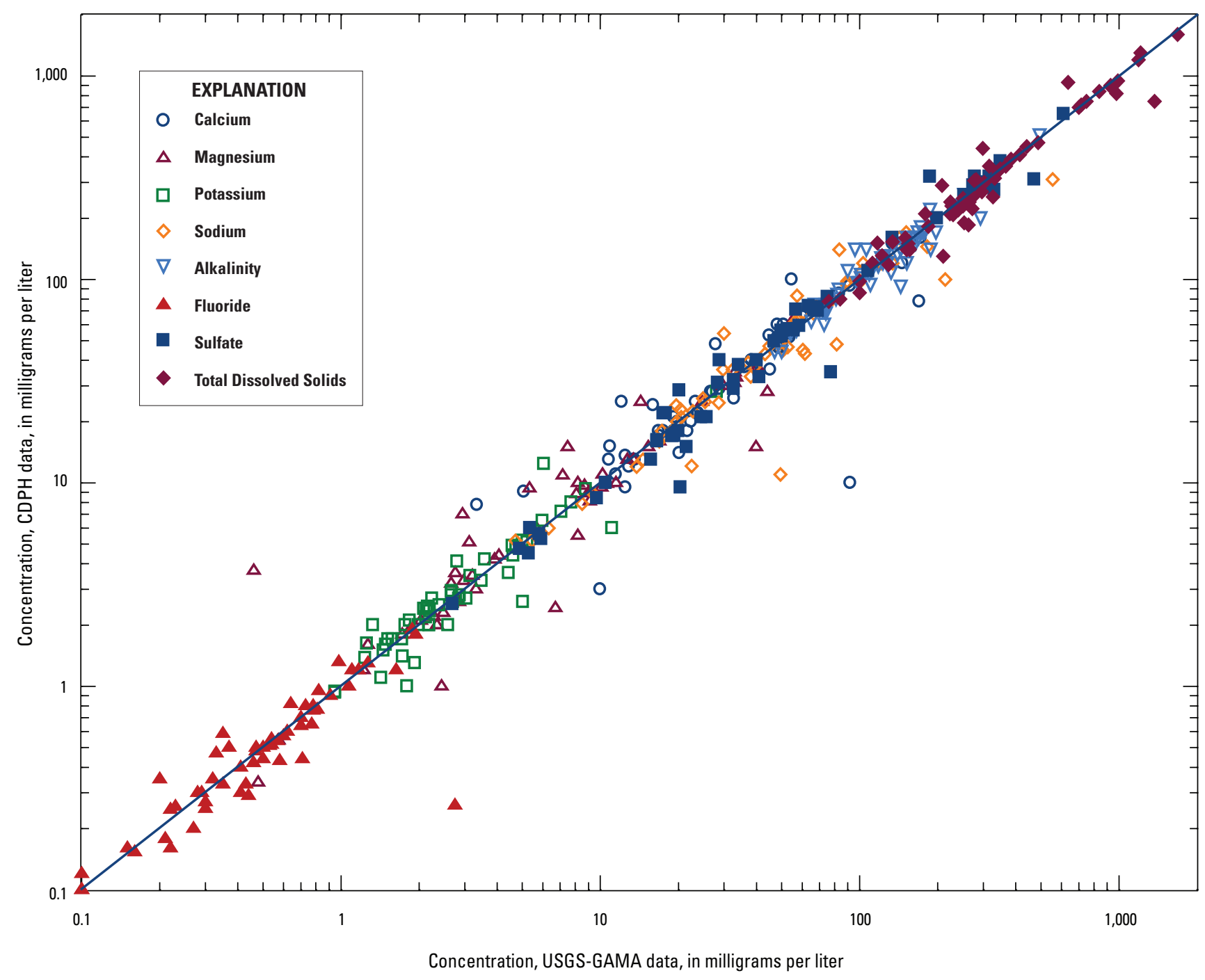

Figure C1. Graph showing paired inorganic concentrations from USGS-GAMA Program data collected from September 2006 to April 2008 and current (2003-2008) California Department of Public Health data in the California Desert Region Groundwater Ambient Monitoring and Assessment (GAMA) study areas. 
C2. A

Owens Valley

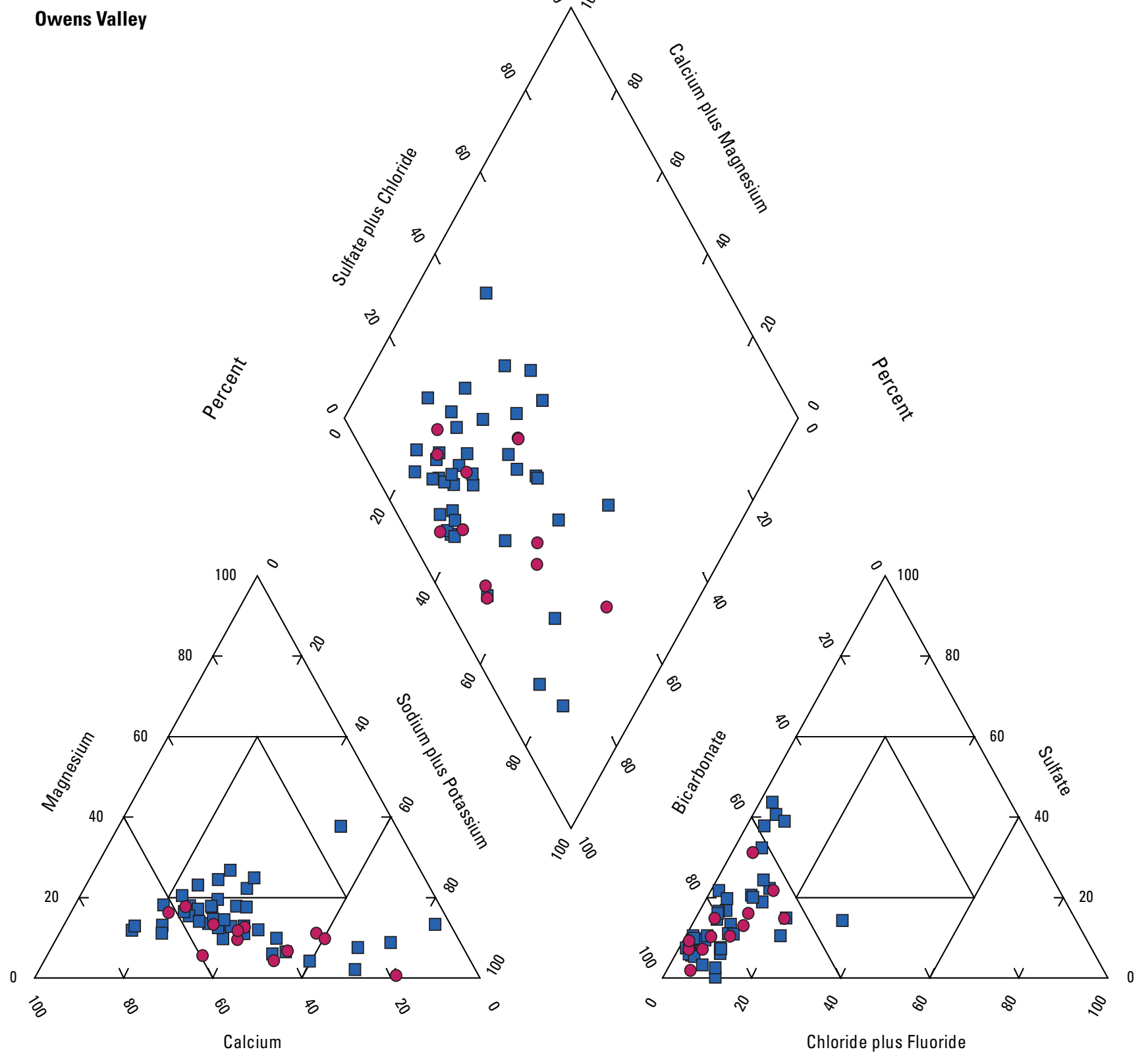

Percent

\section{EXPLANATION}

$\square \quad$ USGS Grid Data

- All CDPH Data

Figures C2. Piper diagrams showing water types in USGS-GAMA wells, 2006-2008, and in all wells in the California Department of Public Health database with a charge imbalance of less than 10 percent in the California Desert Groundwater Ambient Monitoring and Assessment (GAMA) study areas: $(A)$ Owens Valley, $(B)$ Indian Wells Valley, $(C)$ Coachella Valley, $(D)$ Colorado River, (E) Antelope Valley, and ( $F$ ) Mojave. 
C2. B

Indian Wells Valley
0

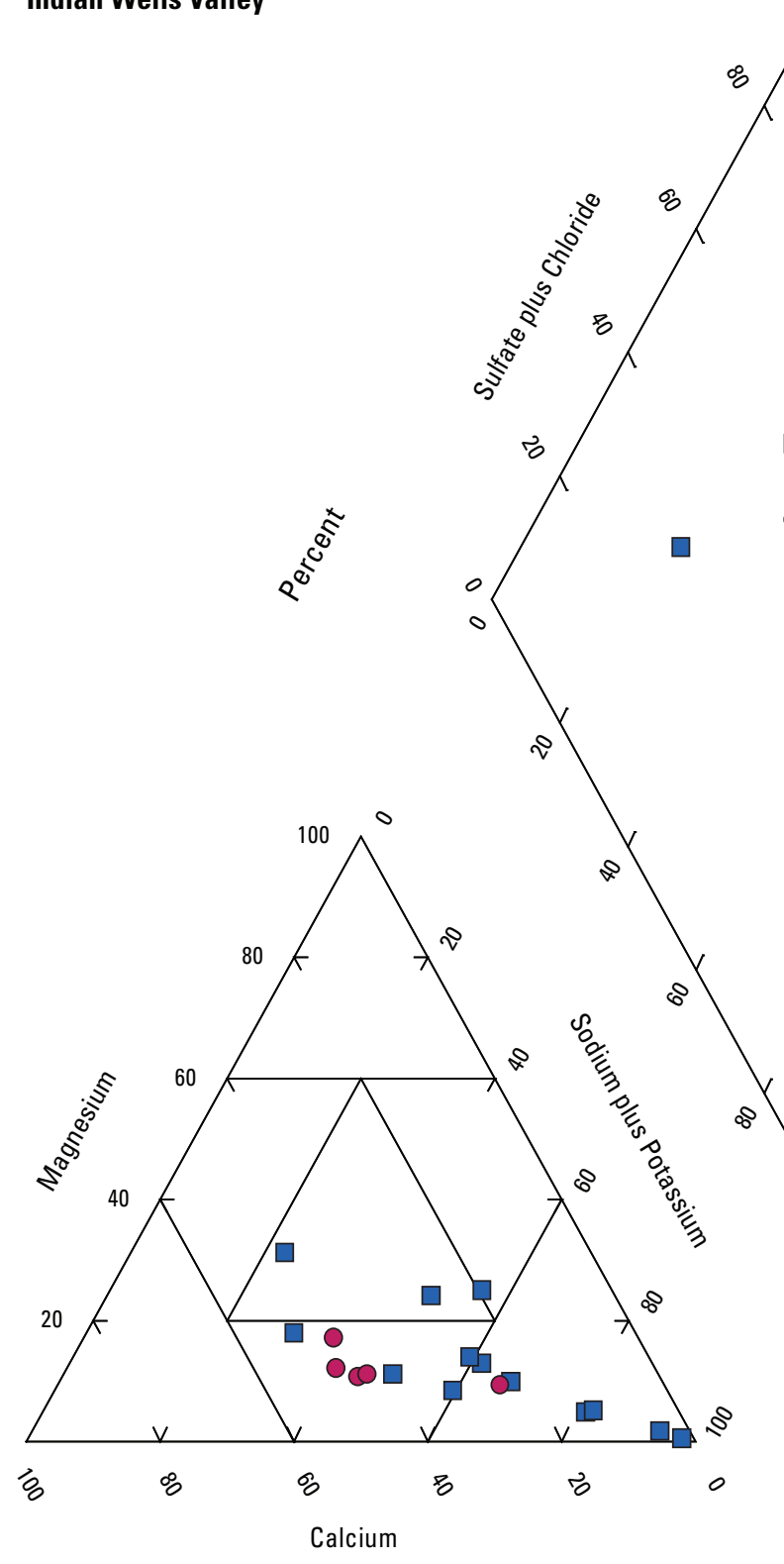

\% 8

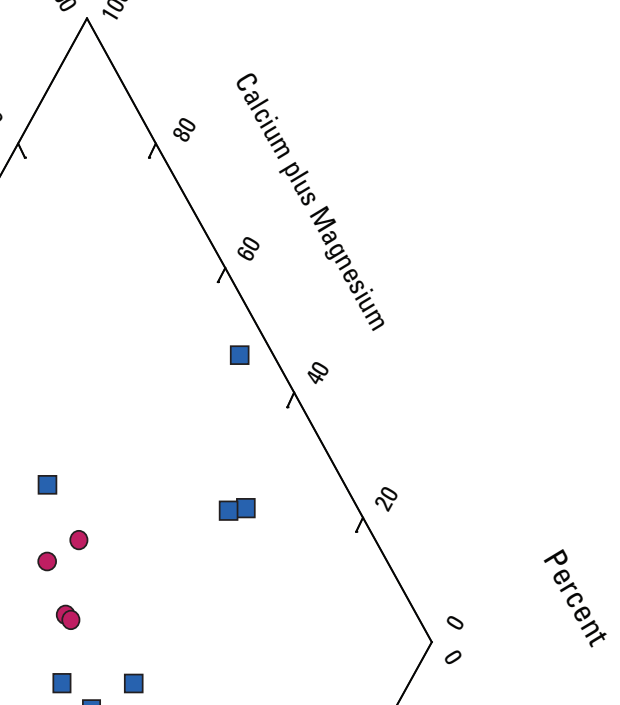

Percent

\section{EXPLANATION}

USGS Grid Data

- All CDPH Data

Figure C2.-Continued 
C2.C

Coachella Valley

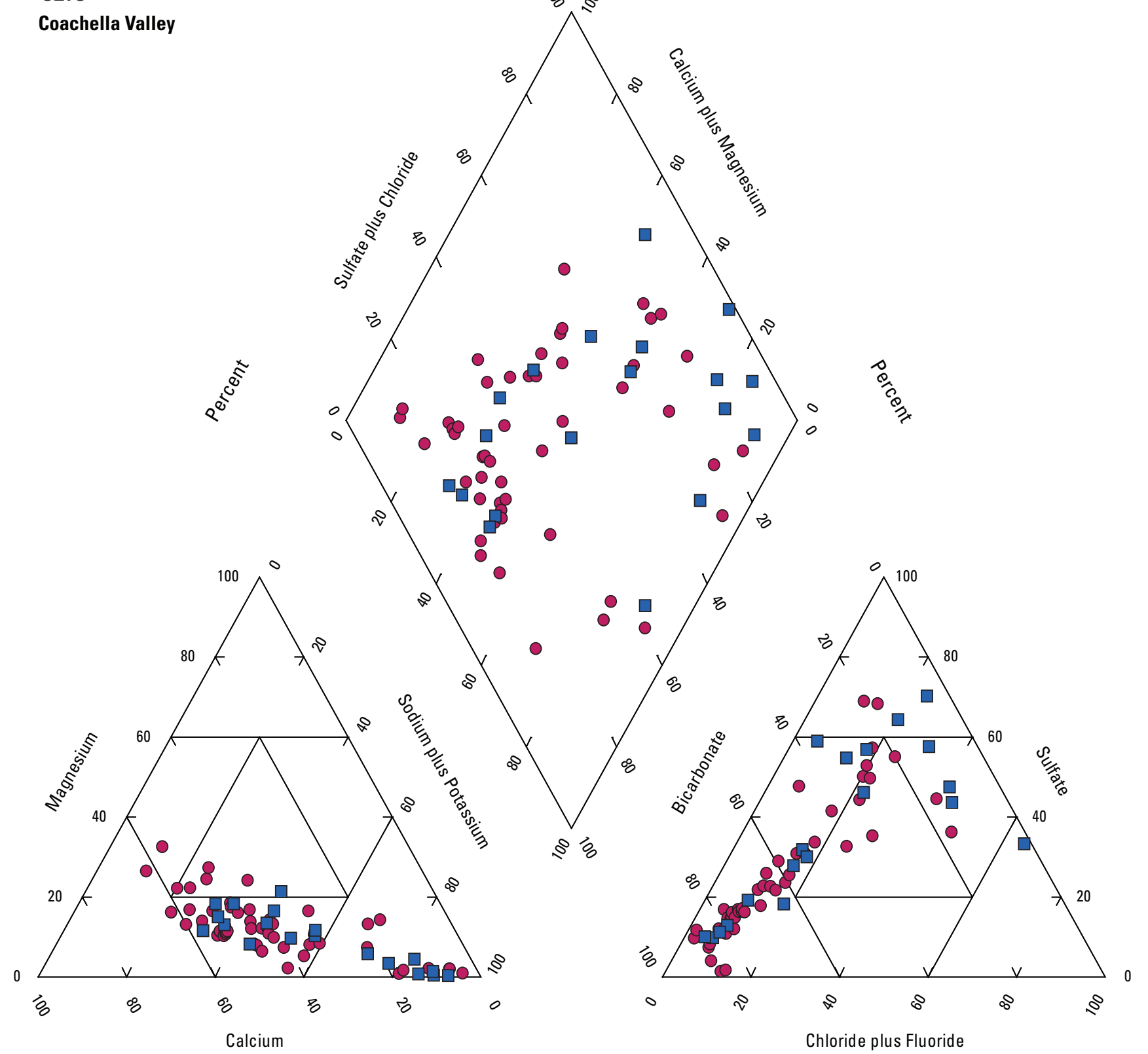

Percent

EXPLANATION

$\square \quad$ USGS Grid Data

- All CDPH Data

Figure C2.-Continued 
C2. D

Colorado River

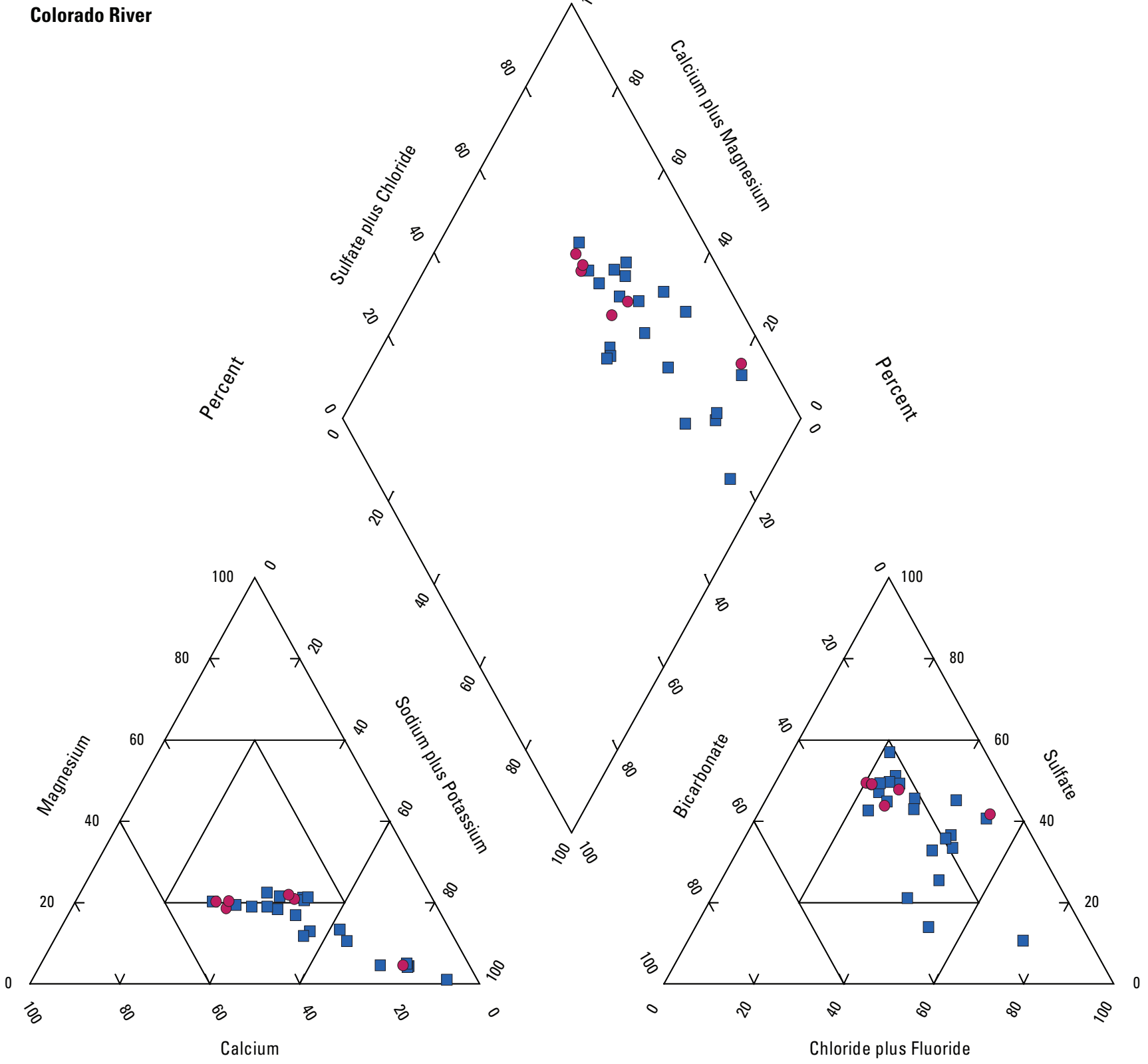

0

Percent

\section{EXPLANATION}

$\square \quad$ USGS Grid Data

- All CDPH Data

Figure C2.-Continued 
C2. E

Antelope Valley
0

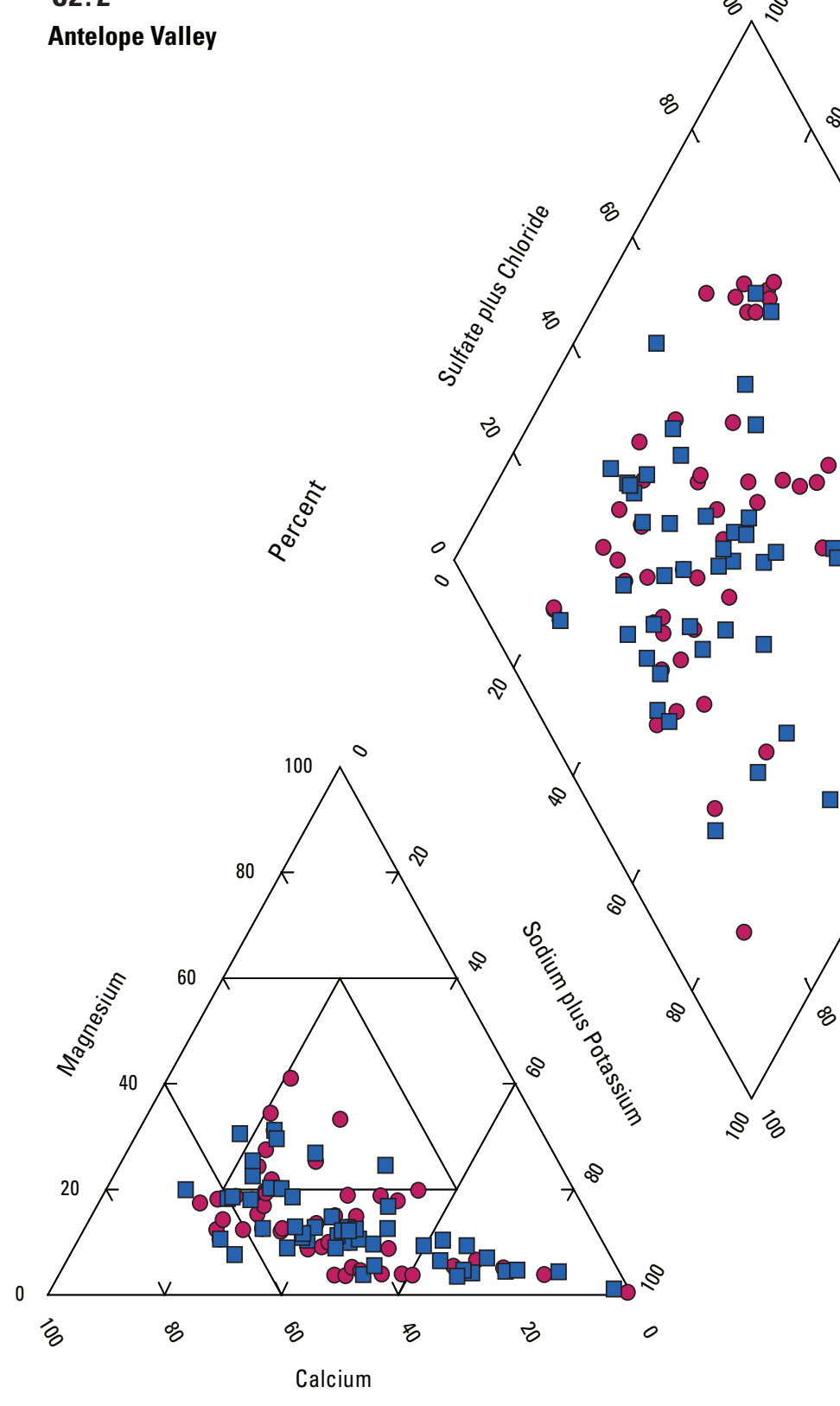

Percent

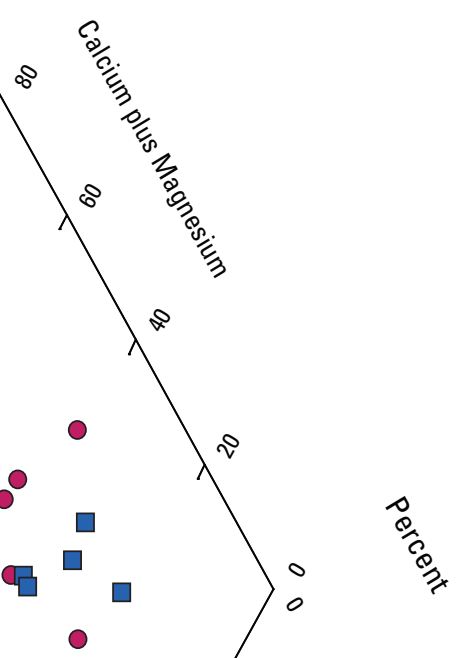

\section{EXPLANATION}

USSGS Grid Data

- All CDPH Data

Figure C2.-Continued 
C2. $F$

Mojave
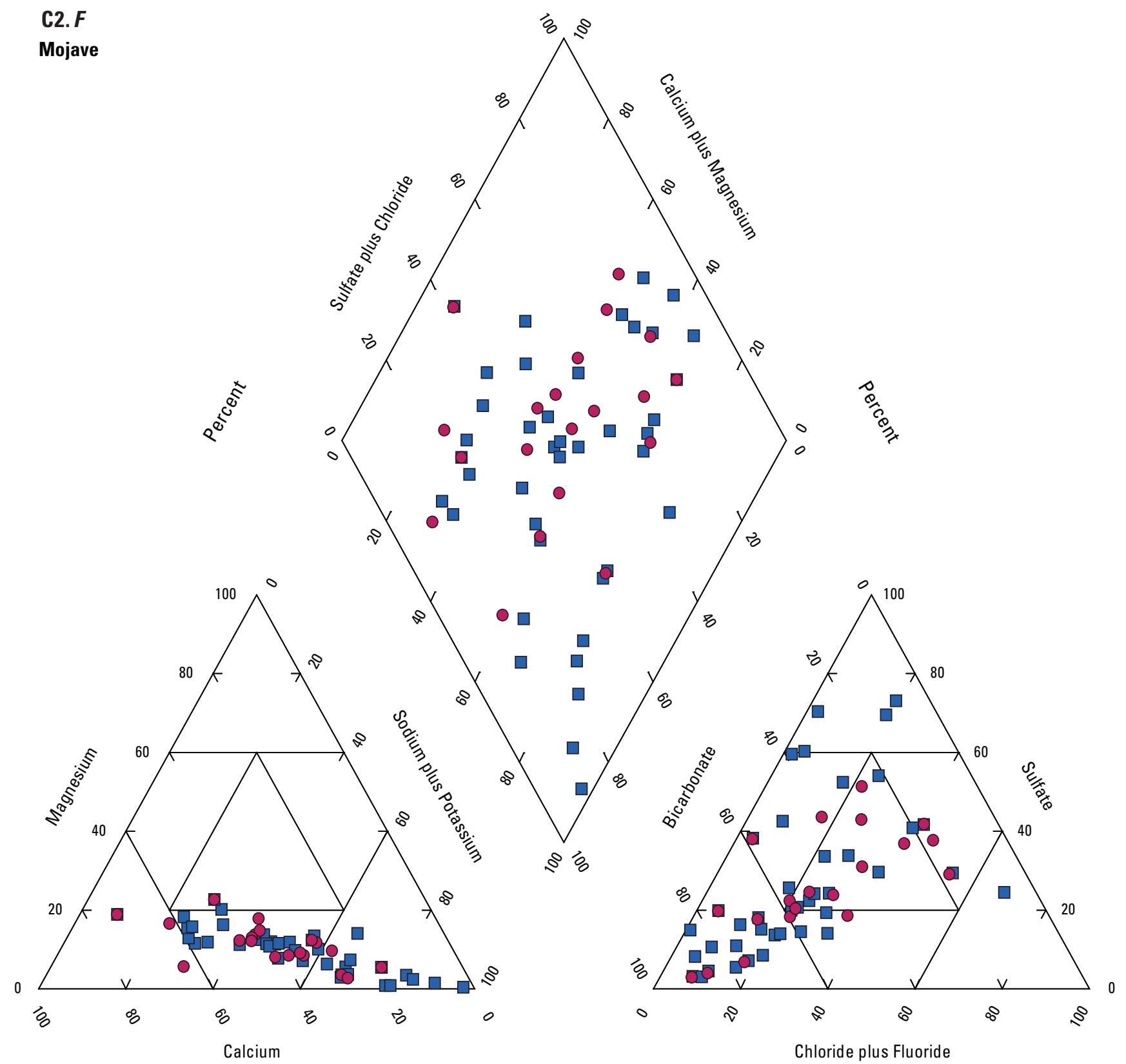

Percent

EXPLANATION

$\square \quad$ USGS Grid Data

- All CDPH Data

Figure C2.-Continued 
Publishing support provided by the U.S. Geological Survey Science

Publishing Network, Sacramento, Tacoma, and Raleigh Publishing Service Centers

For more information concerning the research in this report, contact the Director, California Water Science Center

U.S. Geological Survey

6000 J Street, Placer Hall

Sacramento, California 95819

http://ca.water.usgs.gov 


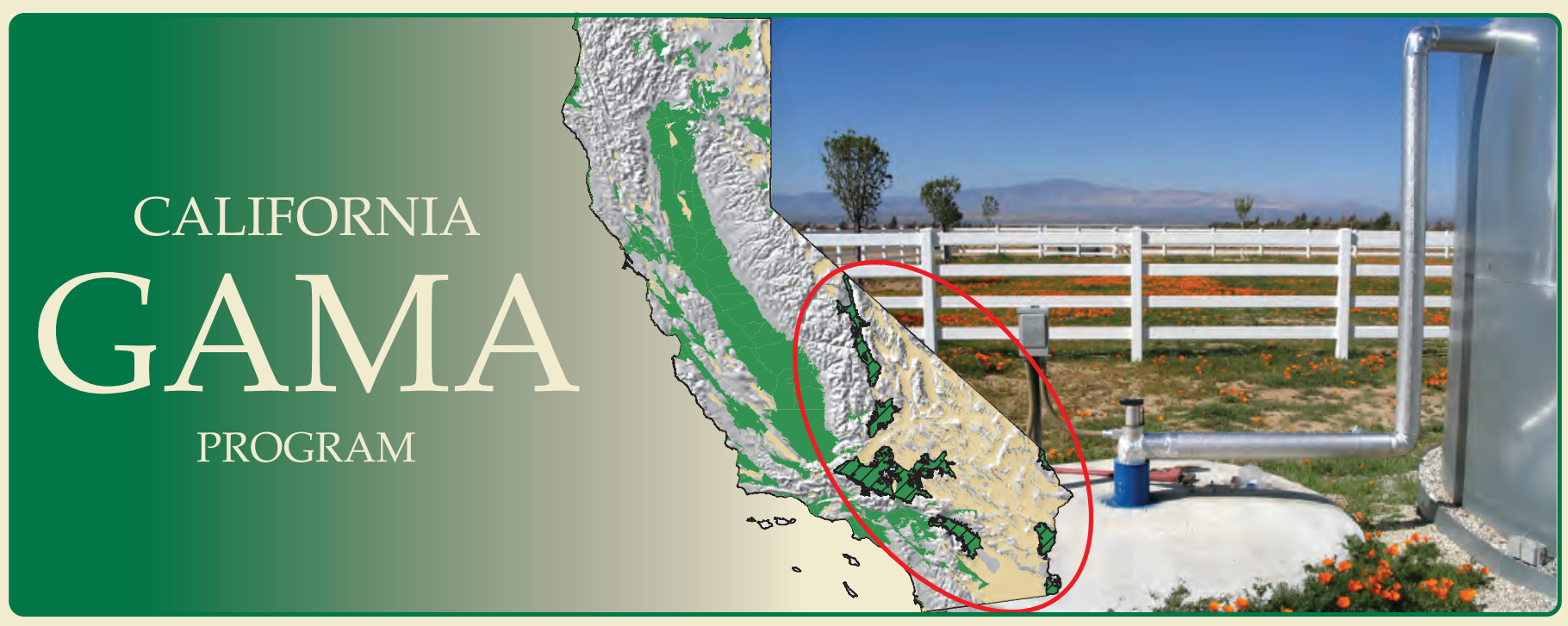

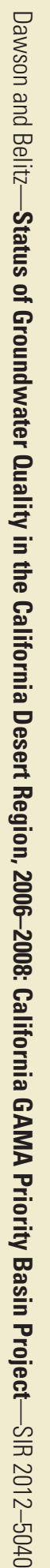

